\title{
Gezondheidsbevordering en voortgezet onderwijs, verstandshuwelijk of echte liefde? : een onderzoek naar de implementatie van schoolgezondheidsbeleid binnen scholen voor voortgezet onderwijs
}

Citation for published version (APA):

Boot, N. M. W. M. (2011). Gezondheidsbevordering en voortgezet onderwijs, verstandshuwelijk of echte liefde? : een onderzoek naar de implementatie van schoolgezondheidsbeleid binnen scholen voor voortgezet onderwijs. [Doctoral Thesis, Maastricht University]. https://doi.org/10.26481/dis.20111118nb

Document status and date:

Published: 01/01/2011

DOI:

10.26481/dis.20111118nb

Document Version:

Publisher's PDF, also known as Version of record

Please check the document version of this publication:

- A submitted manuscript is the version of the article upon submission and before peer-review. There can be important differences between the submitted version and the official published version of record. People interested in the research are advised to contact the author for the final version of the publication, or visit the DOI to the publisher's website.

- The final author version and the galley proof are versions of the publication after peer review.

- The final published version features the final layout of the paper including the volume, issue and page numbers.

Link to publication

\footnotetext{
General rights rights.

- You may freely distribute the URL identifying the publication in the public portal. please follow below link for the End User Agreement:

www.umlib.nl/taverne-license

Take down policy

If you believe that this document breaches copyright please contact us at:

repository@maastrichtuniversity.nl

providing details and we will investigate your claim.
}

Copyright and moral rights for the publications made accessible in the public portal are retained by the authors and/or other copyright owners and it is a condition of accessing publications that users recognise and abide by the legal requirements associated with these

- Users may download and print one copy of any publication from the public portal for the purpose of private study or research.

- You may not further distribute the material or use it for any profit-making activity or commercial gain

If the publication is distributed under the terms of Article 25fa of the Dutch Copyright Act, indicated by the "Taverne" license above,

Download date: 26 Apr. 2023 


\section{Gezondheidsbevordering en voortgezet onderwijs, verstandshuwelijk of echte liefde?}

Een onderzoek naar de implementatie van schoolgezondheidsbeleid binnen scholen voor voortgezet onderwijs.

Nicole Boot,

Academische Werkplaats Publieke Gezondheid Limburg 



\section{Health promotion and secondary education: marriage of convenience or true love?}

An investigation into the implementation of school health policies at Dutch schools for secondary education.

Nicole Boot,

Academic Collaborative Centre for Public Health Limburg, Maastricht 
(C) Copyright: Nicole Boot, Maastricht, 2011

Design \& lay-out: Caris \& Sak, Heerlen

ISBN: 978-94-6190-294-8

Alle rechten zijn voorbehouden. Illustraties en tekst van deze publicatie mogen voor wetenschappelijke, educatieve en praktische doeleinden worden gebruikt met vermelding van de bron.

De studies beschreven in dit proefschrift zijn gefinancierd door de Nederlandse organisatie voor gezondheidsonderzoek en zorginnovatie (projectnr. 7125.0001) met aanvullende financiering van de Academische Werkplaats Publieke Gezondheid Limburg.

\section{Maastricht University}

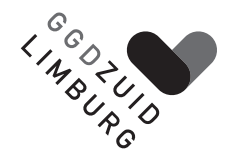




\section{Gezondheidsbevordering en voortgezet onderwijs, verstandshuwelijk of echte liefde?}

Een onderzoek naar de implementatie van schoolgezondheidsbeleid binnen scholen voor voortgezet onderwijs.

\section{Proefschrift}

Ter verkrijging van de graad doctor aan de Universiteit Maastricht, op gezag van de Rector Magnificus, Prof. Mr. G.P.M.F. Mols,

volgens het besluit van het College van Decanen,

in het openbaar te verdedigen op vrijdag 18 november 2011 om 10.00 uur door

Nicole Monique Wilhelmine Marcelle Boot 


\section{Promotor:}

Prof. dr. N.K. de Vries

\section{Beoordelingscommissie:}

Prof. dr. H. de Vries (voorzitter)

Prof. dr. G.J. Kok

Prof. dr. F. Feron

Prof. dr. M.C.H. Donker (Erasmus MC Rotterdam)

Dr. Th. Paulussen (TNO, preventie en zorg) 
Praktijkcommissie:

Drs. B. Hesdahl, afdeling gezondheidsbevordering GGD Zuid Limburg

Drs. J. Aerdts, afdeling gezondheidsbevordering GGD Zuid Limburg

Dr. Ir. M. Jansen, programmaleider Academische Werkplaats GGD Zuid Limburg

Dit proefschrift is tot stand gekomen vanuit de Academische Werkplaats Publieke Gezondheid Limburg, een samenwerkingsverband tussen de GGD Zuid Limburg, de faculteit Health, Medicine and Life Sciences van de Universiteit Maastricht en de 19 Zuid-Limburgse gemeenten. De gepresenteerde studies in dit proefschrift zijn uitgevoerd bij de onderzoeksschool CAHPRI, School for Public Health and Primary Care. 

"Zekerheid is niet de bedoeling van het leven. Grote uitdagingen zijn het risico waard." 



\section{Inhoudsopgave}

Introductie

Deel 1:

Onderbouwing voor schoolgezondheidsbeleid

40

Hoofdstuk 1:

Does school health promotion affect academic achievement?

Deel 2:

Schoolgezondheidsbeleid in Nederland

64

Hoofdstuk 2:

De Gezond School als methode voor GGD'en bij de invoering van schoolgezondheidsbeleid

Deel 3:

Regionaal onderzoek naar schoolgezondheidsbeleid

Hoofdstuk 3:

Gezondheidsbevordering en voortgezet onderwijs:

verstandshuwelijk of echte liefde?

Hoofdstuk 4:

Professional assistance in implementing school health policies

Hoofdstuk 5:

Implementation of school health promotion:

consequences for professional assistance

Hoofdstuk 6:

Evaluatie van de schoolslag-checklist gericht op het beoordelen van schoolse interventies

Discussie

Referenties

Summary

Samenvatting

Dankwoord

Curriculum Vitae

Publicatie overzicht 



\section{Introductie}

\section{Inleiding}

Uit onderzoek is bekend dat gezondere leerlingen beter presteren dan ongezonde leerlingen (Davis \& Cooke, 2007; Suhrcke, 2011). Denk hierbij bijvoorbeeld aan de invloed van ontbijten op het concentratievermogen van leerlingen (Bellisle, 2004; Taras, 2005). Scholen begeleiden leerlingen bij het optimaliseren van hun leerprestaties. Schoolgezondheidsbeleid kan hieraan een bijdrage leveren. Op dit moment heeft gezondheidsbeleid echter nog geen vaste plek binnen de structuur van het onderwijs verworven. Nader onderzoek zowel gericht op de relatie tussen gezondheid en leerprestaties als op de implementatie van schoolgezondheidsbeleid kan een positieve bijdrage leveren aan de positie van gezondheidsbeleid in het onderwijs.

Dit proefschrift is gericht op de schoolslag-werkwijze, een planmatige en systematische manier van werken om scholen te ondersteunen bij de invoering en uitwerking van schoolgezondheidsbeleid.

Sinds de ontwikkeling van de schoolslag-werkwijze in 2002 is de aandacht voor schoolgezondheidsbeleid zowel in Zuid-Limburg als in de rest van Nederland sterk toegenomen (Bos, De Jongh \& Paulussen, 2010). Steeds meer GGD'en ondersteunen scholen bij de invoering van gezondheidsbeleid (Bos, De Jongh \& Paulussen, 2010). Toch is aandacht voor de gezondheid van leerlingen en personeel nog geen vanzelfsprekendheid binnen het onderwijs. Op dit moment is er geen sprake van een wettelijke taakstelling ten aanzien van gezondheidsbeleid in het onderwijs.

De afgelopen jaren is veel ervaring opgedaan met de schoolslag-werkwijze in het voortgezet onderwijs (Leurs en anderen, 2005). Deze ervaringsperiode vormt het uitgangspunt voor het beschreven onderzoek. Binnen dit onderzoek is getracht inzicht te krijgen in de onderbouwing van schoolgezondheidsbeleid en de wijze waarop en de mate waarin schoolgezondheidsbeleid geïmplementeerd wordt bij scholen voor voortgezet onderwijs in Nederland en in Zuid-Limburg in het bijzonder.

Bestaat binnen het huidige systeem van het voortgezet onderwijs de mogelijkheid om gezondheidsbeleid in te voeren of zijn de werelden van onderwijs en gezondheidszorg nog te verschillend waardoor optimale samenwerking nog niet mogelijk is? Kortom, is er sprake van een verstandshuwelijk of van echte liefde wanneer we gezondheidsbeleid willen implementeren in 
het voortgezet onderwijs? Het proefschrift richt zich in het bijzonder op de belemmerende en bevorderende factoren van de implementatie van gezondheidsbeleid in het voortgezet onderwijs. Hier is voor gekozen aangezien de werkwijze bij deze doelgroep is ontwikkeld en geïmplementeerd. In een latere fase is ook het basisonderwijs toegevoegd. Deze groep wordt hier nu buiten beschouwing gelaten.

Om de verschillende hoofdstukken van dit proefschrift goed te kunnen plaatsen wordt in dit inleidend hoofdstuk eerst het kader geschetst waarbinnen het onderzoek heeft plaatsgevonden. Er wordt een definitie gegeven van de begrippen gezondheid, gezondheidsbevordering en schoolgezondheidsbeleid, gevolgd door een beschrijving van het schoolsysteem en een uitgebreide toelichting op de schoolslag-werkwijze en het Healthy School Model. Tevens wordt de internationale context van schoolgezondheidsbeleid nader toegelicht. Vervolgens wordt ingegaan op de relevantie, de theoretische achtergrond, de probleemdefinitie, de onderzoeksvragen en de methoden van onderzoek. De verschillende hoofdstukken van dit proefschrift beschrijven de onderzoeksresultaten op de verschillende onderdelen.

\section{Schoolgezondheidsbeleid}

De Wereld Gezondheid Organisatie (WHO) definieert gezondheid als: "een toestand van volledig lichamelijk, geestelijk en maatschappelijk welzijn en niet slechts de afwezigheid van ziekte en andere lichamelijke gebreken" (WHO, 2006).

Gezondheidsbevordering heeft als doel de gezondheid van mensen te verbeteren, te bevorderen en te behouden. Het is een proces waardoor mensen of groepen van mensen in staat worden gesteld meer controle te verwerven over de determinanten van hun gezondheid, om zo hun gezondheid te verbeteren (World Health Organization, 1986; Brug \& Schaalma, 2000). Het is de taak van de gezondheidsbevorderaar het individu de weg te wijzen in het doolhof van mogelijkheden en waar mogelijk te ondersteunen bij het maken van een weloverwogen en, bij voorkeur, een gezonde keuze.

Gezondheidsbevordering kent een settingspecifieke benadering. Er kan onderscheid worden gemaakt tussen de school, de wijk/buurt en de zorg. In dit proefschrift ligt de nadruk op de setting school. Binnen de setting school kan gezondheidsbeleid een belangrijke rol spelen. Schoolgezondheidsbeleid vertaalt de doelen van gezondheidsbevordering naar de setting school. Het omvat het geheel van activiteiten gericht op gezondheid die op een systematische en structurele manier en in samenwerking met directie, leerkrachten, leerlingen, ouders en personeel wordt ingebed in de organisatie van de school (St.Leger, 2004). De WHO spreekt over "health 
promoting schools' en operationaliseert dit door zes gebieden te benoemen waaraan de school aandacht dient te besteden. Pas als al deze zes gebieden aandacht krijgen is sprake van een 'health promoting school'. Deze gebieden zijn: schoolgezondheidsbeleid, fysieke omgeving van de school, sociale omgeving van de school, school/community relaties, ontwikkeling van persoonlijke gezondheidsvaardigheden en schoolgezondheidsdiensten (Stewart-Brown, 2006). Schoolgezondheidsbeleid behelst een zeer breed terrein. Op alle genoemde aspecten kan beleid worden gemaakt. Echter, wanneer we in het kader van dit proefschrift spreken over schoolgezondheidsbeleid hebben we het over de integrale aanpak van alle hierboven genoemde thema's in een planmatige structuur. Een dergelijke integrale aanpak is niet eenvoudig uitvoerbaar. $\mathrm{Er}$ zijn veel verschillende factoren die de vorming en uitvoering van schoolgezondheidsbeleid positief dan wel negatief beïnvloeden. In de paragraaf over het theoretisch kader wordt hier verder op ingegaan.

Schoolgezondheidsbeleid bevindt zich in een krachtenveld van zowel de landelijke als regionale politiek. Door het ontbreken van een duidelijke taakstelling voor gezondheidsbeleid binnen het onderwijs ontstaat er een grijs gebied ten aanzien van verantwoordelijkheden voor schoolgezondheidsbeleid. Het ministerie van Volksgezondheid, Welzijn en Sport (VWS) is verantwoordelijk voor de wetgeving rondom publieke gezondheid (ministerie van VWS, 2007). Gezondheidsbevordering maakt hier onderdeel van uit. De lokale invulling en uitvoering is op basis van de wet Publieke Gezondheid een gedecentraliseerde verantwoordelijkheid en ligt bij gemeenten. Het ministerie van Onderwijs, Cultuur en Wetenschap (OC\&W) reguleert de wetgeving rondom het onderwijs in Nederland (ministerie van OC\&W, 2001). Ook hierbij is de lokale invulling en uitvoering gedecentraliseerd, maar dan richting schoolbesturen. Schoolgezondheidsbeleid heeft betrekking op beide terreinen. Hieronder wordt een beschrijving gegeven van de organisatie van zowel onderwijs als publieke gezondheid in Nederland, inclusief gezondheidsbevordering.

\section{De organisatie van onderwijs in Nederland}

\section{Wetgeving}

Het ministerie voor OC\&W geeft middels de Wet op het Voortgezet Onderwijs (WVO) invulling aan het onderwijs. Om de kwaliteit van het onderwijs te waarborgen heeft het ministerie verschillende kerndoelen geformuleerd die voor scholen leidend zijn bij de uitvoering van hun beleid (SLO, 2007). Deze kerndoelen zijn gericht op taal, rekenen, mens en natuur, maatschappij, kunst, cultuur, beweging en sport. De Wet op het OnderwijsToezicht (WOT) organiseert de inspectietaak waarmee de naleving van de kerndoelen binnen het onderwijs wordt gecontroleerd (Inspectie van het Onderwijs, 2009). Inspecteurs brengen jaarlijks een bezoek aan alle scholen om naleving van deze kerndoelen te controleren. Naast deze kerndoelen schrijft de overheid 
jaarlijks een kwaliteitsagenda voor het onderwijs. In deze kwaliteitsagenda worden belangrijke aandachtspunten voor het onderwijs beschreven, gebaseerd op de resultaten van de schoolinspecties. Er is geen kerndoel specifiek gericht op gezondheid (VO-raad \& OCW, 2008). Binnen de bestaande kerndoelen zijn wel relaties te leggen met gezondheid, bijvoorbeeld bij maatschappij, beweging en sport. Deze zijn echter niet voorgeschreven. Scholen zijn dan ook niet verplicht schoolgezondheidsbeleid te formuleren.

\section{Landelijke organisatie}

Landelijk hebben scholen voor voortgezet onderwijs zich verenigd in de Voortgezet Onderwijsraad (VO-raad). Dit is een koepelorganisatie met vertegenwoordigers vanuit verschillende disciplines uit het onderwijs die de belangen van besturen en scholen bij de overheid en maatschappelijke organisaties behartigt (VO-raad, 2009). Binnen de V0-raad zijn verschillende kennisgroepen actief. Deze groepen adviseren de VO-raad, gevraagd en ongevraagd, over specifieke thema's. Op deze manier blijft de VO-raad op de hoogte van wat er leeft en speelt op de scholen. Daarnaast hebben de kennisgroepen invloed op het beleid en de standpunten van de VO-raad. Op dit moment is geen kennisgroep actief gericht op gezondheid (VO-raad, 2009). De VO-raad stelt kaders voor de praktische vertaling van de kerndoelen en kwaliteitsagenda op regionaal niveau.

\section{Lokale organisatie}

Op lokaal niveau zijn de scholen in het voortgezet onderwijs georganiseerd in schoolbesturen. In heel Nederland zijn er 356 schoolbesturen voor 1290 scholen. In Zuid-Limburg zijn 25 scholen voor voortgezet onderwijs bestaande uit 45 schoollocaties verdeeld over 5 schoolbesturen. De voornaamste taak van een schoolbestuur is het creëren van randvoorwaarden, waardoor individuele scholen vorm kunnen geven aan de kerndoelen en de aandachtspunten van de kwaliteitsagenda van de overheid. Zoals eerder beschreven maakt gezondheid geen onderdeel uit van deze kerndoelen (SLO, 2007). Het schoolbestuur kan ervoor kiezen scholen de opdracht te geven extra aandacht aan gezondheid te besteden.

\section{Organisatie op schoolniveau}

De kerndoelen en aandachtspunten uit de kwaliteitsagenda van het landelijke beleid dienen vertaald te worden naar de praktijk en opgenomen in het beleid van de school. Hierbij dienen scholen zich te houden aan de randvoorwaarden die het schoolbestuur heeft gesteld (Turkenburg, 2008).

Binnen de randvoorwaarden van het schoolbestuur zijn scholen vrij om hun eigen beleid en doelen te formuleren, bijvoorbeeld gericht op gezondheid, mits ze voldoen aan wettelijke kaders van de overheid. 
De interne organisatiestructuur van scholen voor voortgezet onderwijs verschilt sterk per school, mede afhankelijk van de grootte van de school. Veelal hebben ze een directeur, bij grote scholengemeenschappen ondersteund door een of meerdere locatiedirecteuren. Daarnaast is het docentencorps onderverdeeld in teams. Deze indeling gebeurt veelal op basis van vakinhoud of leerlagen. De teams worden aangestuurd door een teamleider. Deze teamleider is verantwoordelijk voor de afstemming van de onderwijsdoelen in zijn team. Hiervoor legt hij verantwoording af aan de directeur dan wel locatieleider. Naast de docententeams zijn verschillende professionals aangesteld binnen school. Hierbij valt te denken aan een veiligheidscoördinator, een conciërge, remedial teacher, vertrouwenspersoon, maar ook een zorgcoördinator. Daarnaast zijn vaak ouderraden en leerling-panels aangesteld om de directie van de school, gevraagd en ongevraagd, te adviseren over specifieke thema's.

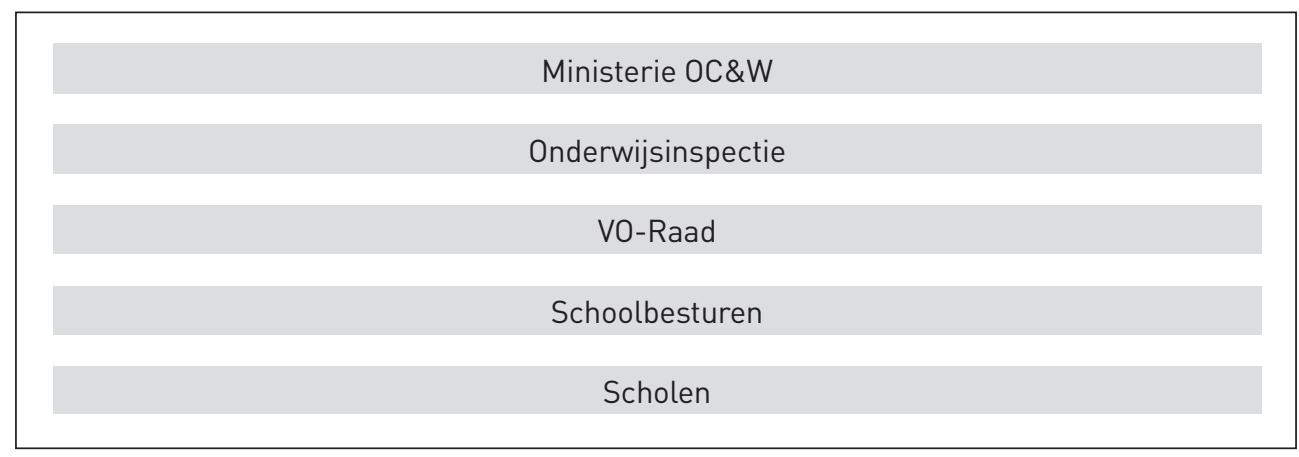

Figuur 1: Schematische weergave organisatie van onderwijs in Nederland.

\section{De organisatie van gezondheidsbevordering in Nederland}

\section{Wetgeving}

De organisatie van de publieke gezondheid, waaronder gezondheidsbevordering, valt onder de verantwoordelijkheid van het ministerie van Volksgezondheid, Welzijn en Sport (VWS). Wanneer we specifiek kijken naar de taken gericht op jeugd, beschrijft de Wet publieke gezondheid (Wpg, 2008) dat iedere gemeente dient zorg te dragen voor:

a. signaleren van de gezondheidstoestand van jeugdigen en van gezondheidsbevorderende en -bedreigende factoren,

b. signaleren van zorgbehoeften,

c. de vroegtijdige opsporing en preventie van specifieke stoornissen,

d. het geven van voorlichting, advies, instructie en begeleiding,

e. het formuleren van maatregelen ter beïnvloeding van gezondheidsbedreigingen. 
Naast deze algemeen geldende taken bepaalt het ministerie van VWS via de landelijke preventienota de inhoudelijke prioriteiten. Gebaseerd op de Volksgezondheid Toekomst Verkenning (VTV) die iedere vier jaar landelijk wordt uitgevoerd, worden speerpunten voor gezondheidsbevordering geformuleerd. Deze speerpunten zijn bepalend voor de uitwerking van het regionale en lokale beleid. Gemeenten zijn verantwoordelijk voor de uitvoering van dit beleid. In opdracht van de gemeente voert de GGD een groot deel van de beschreven taken uit. De inspectie voor de Gezondheidszorg beoordeelt of de wetgeving door gemeenten en GGD'en in voldoende mate wordt nageleefd en informeert hierover het ministerie van VWS (Inspectie voor de gezondheidszorg, 2005). Inspecteurs brengen jaarlijks een bezoek aan de GGD'en om toezicht te houden en de uitvoering door de GGD'en te toetsen aan de wet.

De taakstelling gericht op het signaleren van de gezondheidstoestand van de jeugdigen, het signaleren van de zorgbehoefte en het geven van voorlichting, advies en begeleiding legitimeren de inzet van GGD'en bij de invoering van schoolgezondheidsbeleid binnen het voortgezet onderwijs omdat de GGD kan optreden als verlengd lokaal bestuur.

\section{Landelijke organisatie}

Landelijk hebben GGD'en zich verenigd in GGD Nederland. De voornaamste taak van GGD Nederland is belangenbehartiging op de vier beleidsterreinen te weten: jeugd, publieke gezondheidszorg, infectieziektebestrijding en kwaliteit van alle diensten en producten van GGD'en IGGD Nederland, 2011). Naast de koepelorganisatie voor GGD'en zijn er verschillende landelijk organisaties actief. Voorbeelden hiervan zijn: het Voedingscentrum, het Trimbos Instituut landelijk kennisinstituut voor geestelijke gezondheidszorg, verslavingszorg en maatschappelijke zorg, STIVORO het expertisecentrum voor tabakspreventie, SOA-Aids Nederland voor preventie van onveilige seksuele contacten, Pharos voor gezondheid onder minderheden, Consument en Veiligheid voor de preventie van veiligheid, NISB voor lichamelijke beweging en het NIGZ voor de ondersteuning van professionals bij de ontwikkeling en uitvoering van gezondheidsbevordering. Deze landelijke organisaties ontwikkelen preventiemateriaal, evalueren programma's en ondersteunen regionale instellingen bij de implementatie van de programma's in hun regio (GGD Nederland).

Het RIVM Centrum Gezond Leven (CGL) heeft sinds 2009 een spilfunctie in de verzameling, verrijking en verspreiding van kennis op het vlak van gezondheidsbevordering in Nederland. De werkzaamheden voert CGL uit met inzet van de hiervoor genoemde landelijke thema-instituten. Het RIVM is een agentschap van het ministerie van VWS. CGL biedt lokale professionals een platform voor kennisuitwisseling op het gebied van gezondheidsbevorderende leefstijl- en omgevingsgerichte interventies. Het maakt bestaande interventies voor een brede groep beschikbaar en controleert de kwaliteit en samenhang. Hierbij werkt zij aan de ondersteuning van ge- 
zondheidsbevordering in settings, waaronder de setting school. Het programma Gezonde School bouwt voort op de kennis van en ervaring met de schoolslag-werkwijze in Zuid-Limburg. Het CGL ontwikkelt met zijn partners hulpmiddelen als handleidingen, opleidingen en inmiddels ook een 'vignet gezonde school' die alle bijdragen aan een brede implementatie van de Gezonde School in heel Nederland.

\section{Lokale organisatie}

In Nederland zijn op dit moment 28 GGD'en. Hun voornaamste taak is het bewaken, beschermen en bevorderen van de gezondheid van de bevolking (GGD Nederland).

Om de taken zoals beschreven in de Wpg goed uit te voeren wordt iedere vier jaar een lokale gezondheidsnota opgesteld door gemeenten. In deze nota worden de plannen beschreven voor de komende periode. De speerpunten van deze nota zijn afgeleid van de Volksgezondheid Toekomst Verkenning (VTV) die door het RIVM elke vier jaar wordt uitgebracht. Regionaal kan deze worden bewerkt, waardoor een regionale VTV (rVTV) tot stand komt, gebaseerd op gezondheidsmonitors, buurtpeilingen, zorgregistraties en gegevens van het Centraal Bureau voor de Statistiek (CBS). Deze rVTV geeft inzicht in de regionale gezondheidssituatie.

Op schoolniveau worden de monitorgegevens van de jeugd gebruikt voor het stellen van prioriteiten. Met behulp van de jeugdmonitor (onderdeel van de rVTV) worden schoolrapportages gemaakt en de belangrijke speerpunten voor de jeugd op schoolniveau bepaald.

In dit proefschrift ligt de focus op schoolgezondheidsbeleid. Jongeren vormen één van de doelgroepen van de GGD. Andere belangrijke doelgroepen zijn ouderen en volwassenen in een kwetsbare positie. Daarnaast zijn er programma's gericht op settings zoals wijken, scholen, gezondheidzorgcentra en gemeenten. De school is een belangrijke setting om jongeren kennis te laten maken met een gezonde leefstijl. De invoering van schoolgezondheidsbeleid is hierbij een belangrijk hulpmiddel.

Net als de veelheid van landelijke organisaties die actief zijn op het terrein van schoolgezondheidsbevordering, is ook regionaal de GGD niet de enige organisatie die verantwoordelijk is voor schoolgezondheidsbeleid. In Zuid-Limburg leveren diverse organisaties een bijdrage aan preventie van ongezond gedrag en het bevorderen van een gezonde leefstijl bij jongeren. ledere organisatie heeft een eigen expertise gericht op een specifiek onderwerp zoals verslaving, psychosociale ontwikkeling, welzijn, sport en beweging, seksuele opvoeding, angst of depressie. De sch ool is de belangrijkste vindplaats van jongeren. Om die reden is de school als setting zeer geliefd bij allerlei gezondheidsbevorderende instellingen (landelijk en regionaal). Scholen worden bedolven onder de veelheid van activiteiten en advies van deze instellingen. Scholen hebben 
geen wettelijke taak ten aanzien van gezondheidsbeleid en er is geen vaste adviesstructuur beschikbaar, waardoor scholen door allerlei partijen onafhankelijk van elkaar benaderd worden. Een goede coördinatie van het aanbod is wenselijk gebleken voor scholen.

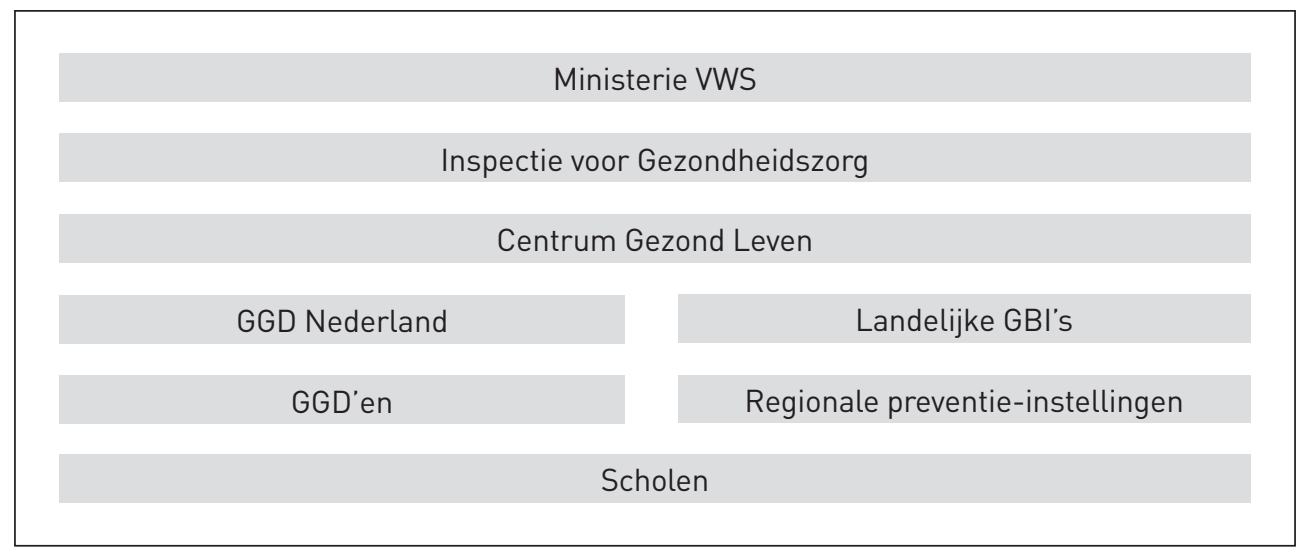

Figuur 2: De organisatie van gezondheidsbevordering in Nederland, toegespitst op de school als setting.

\section{Organisatie leerlingenzorg aanknopingspunt schoolgezondheidsbeleid}

Uit voorgaande paragrafen blijkt dat de wetgeving rondom onderwijs en gezondheid in Nederland los van elkaar zijn vormgegeven. De verbinding tussen de beide beleidsterreinen vormt de basis voor schoolgezondheidsbeleid, maar deze verbinding kent dus geen wettelijke basis. In tegenstelling tot schoolgezondheidsbeleid is voor de leerlingenzorg binnen het onderwijs wel een verbinding gerealiseerd tussen de beleidsterreinen van onderwijs en zorg. Leerlingenzorg is dan ook een goed voorbeeld om de meerwaarde van wettelijk vastgelegde samenwerking tussen beleidsterreinen te illustreren.

Leerlingenzorg heeft inmiddels een sterke positie binnen het onderwijs ingenomen, mogelijk doordat de veelal negatieve gevolgen van de aanwezigheid van zorgleerlingen direct merkbaar zijn. Binnen de hoge werkdruk is het voor docenten vaak een zware belasting om extra aandacht te geven aan zorgleerlingen. Deze leerlingen worden vaak als "lastig" bestempeld en komen in een zorgcircuit. Omdat iedere leerling recht heeft op passend onderwijs is een school verplicht een zorgstructuur in te richten om zorgleerlingen een passend aanbod te kunnen bieden (Bosdriesz \& Berkenbosch, 2003; Wijsmuller, 2002). Op iedere school is een zorgcoördinator aangesteld om de zorg rondom risicoleerlingen te coördineren. Ter ondersteuning zijn Zorg 
Advies Teams (ZAT)-teams ingericht. In deze ZAT-teams zijn relevante gezondheidsinstellingen vertegenwoordigd. Tijdens vergaderingen worden individuele leerlingen besproken en wordt een passend zorgplan opgesteld. Over het algemeen heeft de jeugdarts zitting in het ZAT-team en is direct betrokken bij de zorg van risico-leerlingen. Ook is de afdeling jeugdgezondheidszorg verantwoordelijk voor de periodieke gezondheidsonderzoeken van leerlingen in het voortgezet onderwijs. Mede door deze onderzoeken worden leerlingen met een verhoogd risico op gezondheid- of gedragsproblemen gesignaleerd en kan vroegtijdig een zorgplan worden opgestart.

De steeds sterker wordende positie van zorg binnen het onderwijs kan een belangrijke ingang voor schoolgezondheidsbeleid zijn. De betrokken samenwerkingspartners voor de zorg zijn vaak ook belangrijke samenwerkingspartners voor gezondheidsbevordering.

Deze bestaande contacten en structuren kunnen worden uitgebreid met een structuur voor gezondheidsbevordering. Wanneer we aan de voorkant investeren in de gezondheid van leerlingen, met behulp van schoolgezondheidsbeleid, kan dit bijdragen aan het terugbrengen van het aantal zorgleerlingen. Juist het terugdringen van het aantal zorgleerlingen zou voor scholen een belangrijke motivatie kunnen zijn om meer preventief gericht schoolgezondheidsbeleid te overwegen.

\section{Schoolslag}

De hierboven beschreven gescheiden organisatie van onderwijs en gezondheidsbevordering, de veelheid van organisaties die scholen benaderen met aanbod op het gebied van gezondheidsbevordering en het ontbreken van enige structuur is de aanleiding geweest voor de ontwikkeling van de schoolslag-werkwijze. Schoolslag is een samenwerkingsverband tussen GGD Zuid Limburg en vier partnerorganisaties in het werkveld van preventie: Mondriaan Zorggroep (verslavingspreventie), Bureau Jeugdzorg, RIAGG Maastricht (geestelijke gezondheidszorg) en Trajekt (welzijnswerk). Gezamenlijk en met begeleiding vanuit Maastricht University is een strategie ontwikkeld om scholen te ondersteunen bij de vormgeving en implementatie van schoolgezondheidsbeleid.

Binnen de schoolslag-werkwijze zijn vier uitgangspunten geformuleerd. Allereerst wordt de school centraal gesteld. De schoolslag-werkwijze gaat uit van de situatie en de problemen van de schoolpopulatie en de daaruit voortvloeiende prioriteiten. Ten tweede is de schoolslag-werkwijze planmatig en structureel. Er wordt planmatig gewerkt in een cyclus van vier jaar. Wat een school doet op het gebied van gezondheid en zorg is idealiter van structurele aard en vastgelegd 
in het school(zorg)plan. Als derde streeft de schoolslag-werkwijze naar een sluitende aanpak in de zorgketen. Goede individuele leerlingenzorg begint met collectieve gezondheidsbevordering en preventie gericht op de hele schoolpopulatie. Het vierde en laatste uitgangspunt is gericht op structurele samenwerkingsafspraken met organisaties uit de regio die werkzaam zijn op het gebied van gezondheid, welzijn en veiligheid. Deze samenwerking is gericht op het terugdringen van het ongecoördineerd aanbieden van een groot aantal preventieprogramma's vanuit de landelijke en regionale gezondheidsbevorderende instellingen aan scholen. Daarnaast zijn samenwerkingsafspraken gemaakt om scholen te helpen een 'gezonde en veilige school' te worden.

\section{Healthy School Model}

Bij de ontwikkeling van de schoolslag-werkwijze zijn de basisprincipes van het Amerikaanse 'Coördinated School Health Program' als uitgangspunt genomen. Deze aanpak staat bekend als het 'Healthy School Model' (Marx \& Wooley, 1998). Voor de ontwikkeling van het 'Healthy School Model' zijn de zes aspecten die de WHO noemt (schoolgezondheidsbeleid, de fysieke omgeving van de school, sociale omgeving van de school, school/community relaties, ontwikkeling van persoonlijke gezondheidsvaardigheden en schoolgezondheidsdiensten (Stewart-Brown, 2006) verder geoperationaliseerd in acht componenten, die ieder een bijdrage leveren aan de gezondheid en het welzijn van leerlingen en medewerkers. Deze componenten zijn:

1. Gezond en veilig schoolklimaat (zowel fysieke omgeving en inrichting van gebouw als het sociaal emotionele klimaat)

2. Psychologische en sociaal emotionele ondersteuning en begeleiding

3. Zorgaanbod

4. Voeding (beleid/regels, voorzieningen/aanbod)

5. Sport en bewegen (zowel lessen lichamelijke opvoeding als mogelijkheden in de pauzes)

6. Gezondheidseducatie (lessen/voorlichting)

7. Gezondheidsbevordering op de werkplek

8. Ouder- en buurtparticipatie

Het model (zie figuur 3 op pagina 23) benadrukt bijvoorbeeld dat gezondheidsbevordering en preventie niet beperkt mogen blijven tot klassikaal onderwijs over gezondheid en gedrag, maar dat ook zaken als zorg voor medewerkers, het voedingsaanbod in de schoolkantine en automaten, een veilig speelplein en afspraken over trakteren meegenomen worden in een totaal schoolgezondheidsplan. Door bij elk vraagstuk te kijken naar de in te zetten strategieën in de juiste combinatie en hier een samenhangend, meerjarig geheel van te maken, stijgt de kans op succes. Actieve participatie en betrokkenheid van leerlingen, docenten en ouders zijn daarbij van groot belang. 


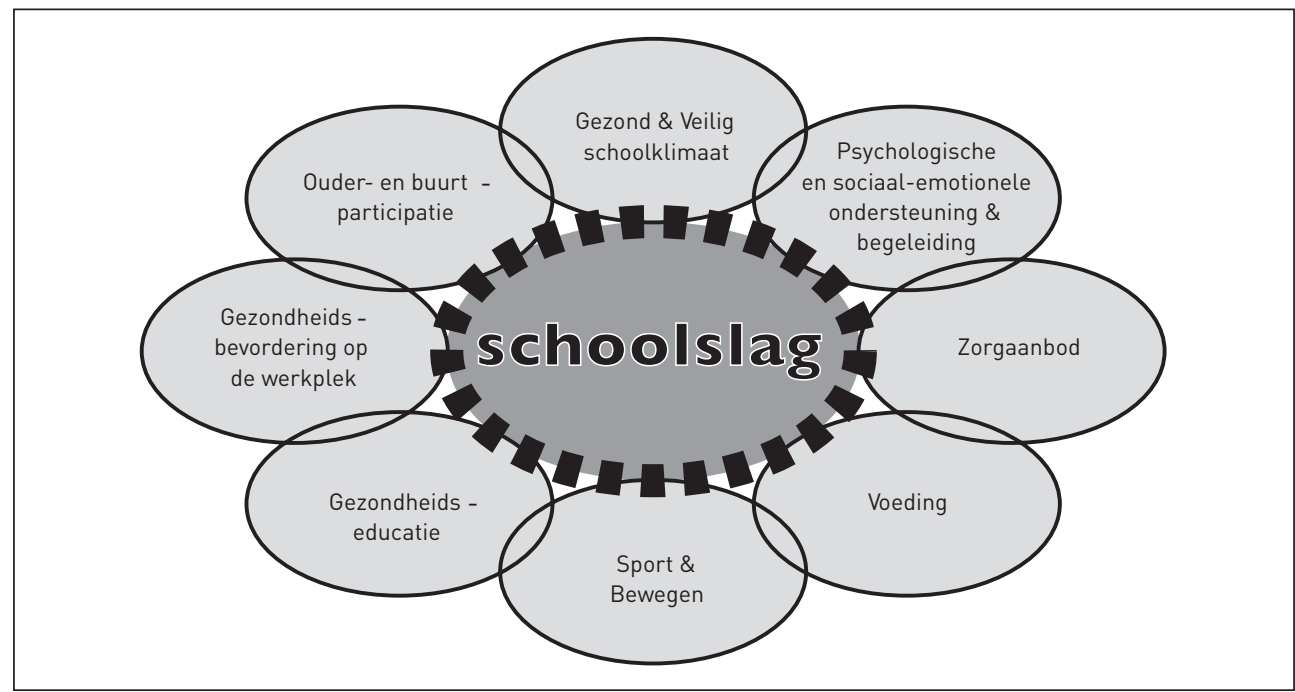

Figuur 3: Gezonde School Model.

In de periode 2002-2005 zijn de principes van het Healthy School Model door Leurs (Leurs, Steenbakkers \& Jansen, 2006) in de schoolslag-werkwijze vertaald naar de Nederlandse situatie en toegepast in Zuid-Limburg. Inmiddels wordt de schoolslag-werkwijze door het Centrum Gezond Leven als basis gebruikt voor de landelijke implementatie van schoolgezondheidsbeleid onder de naam: Gezonde School (CGL-RIVM, 2011). Ook op Europees niveau worden de basisprincipes van de schoolslag-werkwijze toegepast. Via Schools for Health in Europe (SHE), het Europese netwerk voor gezondheidsbevordering op scholen, zijn de basisprincipes van de werkwijze vertaald en ingezet als Europese standaard voor de participerende landen (SHE, 2011). In het netwerk participeren zesenveertig landen (SHE, 2011). Als praktische uitwerking van het SHE netwerk is het Healthy Eating and Physical Activity in Schools (HEPS) project gestart, een project gericht op het verminderen van het aantal kinderen met overgewicht in Europa. Binnen dit project worden de basisprincipes van planmatig werken om schoolgezondheidsbeleid te realiseren toegepast voor het thema overgewicht (HEPS, 2011). Hierbij zijn voor een groot deel de producten van de schoolslag-werkwijze, zoals het schoolslag-stappenplan en de schoolslagchecklist (hoofdstuk 6), als basis gebruikt.

\section{De schoolslag-werkwijze}

Om de schoolslag-werkwijze te kunnen implementeren in de praktijk is in de regio ZuidLimburg een begeleidingsstructuur opgezet. Er zijn verschillende instrumenten ontwikkeld die bijdragen aan de ontwikkeling en implementatie van schoolgezondheidsbeleid. Hieronder worden de verschillende onderdelen toegelicht. 


\section{De schoolslag-adviseur}

De schoolslag-werkwijze gaat uit van één contactpersoon per school die het hele preventieveld en alle preventieprofessionals vertegenwoordigt. ledere participerende organisatie heeft een medewerker beschikbaar gesteld als contactpersoon voor de scholen. In totaal zijn 5 schoolslag-adviseurs gestart om namens de partner-organisaties scholen te begeleiden bij de vormgeving van schoolgezondheidsbeleid.

\section{De schoolslag-contactpersoon}

Om schoolgezondheidsbeleid structureel onderdeel uit te laten maken van het beleid en de praktijk van de school dient de school zich verantwoordelijk te voelen voor het proces. ledere participerende school wordt gevraagd een schoolslag-contactpersoon aan te stellen binnen het team met taakuren voor gezondheidsbevordering. Met ondersteuning van de schoolslagadviseur is deze persoon verantwoordelijk voor de implementatie van schoolgezondheidsbeleid en legt hierover verantwoording af aan de directie.

\section{De schoolslag-inventarisatie}

Een van de taken van de schoolslag-adviseur is de school te begeleiden bij de selectie van concrete activiteiten en preventieprogramma's bij de geformuleerde prioriteiten. Omdat de schoolslag-adviseur alle partnerorganisaties vertegenwoordigt is kennis over het preventieaanbod van lokale, regionale en landelijke partners van groot belang. Ter ondersteuning is een inventarisatie geschreven waarin het preventieaanbod van alle partnerorganisaties en andere aanbieders landelijk en regionaal is gebundeld. Deze inventarisatie wordt jaarlijks geactualiseerd.

\section{De schoolslag-checklist}

Bij het kiezen van activiteiten voor de uitwerking van de vastgestelde inhoudelijke prioriteiten van de betreffende school is het van groot belang dat gebruik wordt gemaakt van bewezeneffectieve programma's. Welk programma past bij de behoefte van de school en welke activiteiten zijn onderzocht op effectiviteit? Om de schoolslag-adviseur te ondersteunen bij deze taak is de schoolslag-checklist ontwikkeld, een beoordelingsinstrument voor schoolse interventies (Leurs, Schaalma, Jansen en anderen, 2007). De checklist draagt bij aan het faciliteren en systematiseren van de keuze van interventies die op scholen kunnen worden uitgevoerd en wordt met name ingezet in de vierde stap van het schoolslag-stappenplan. Naast criteria die preventieprofessionals aanleggen zoals effectiviteit, is ook rekening gehouden met factoren die voor het onderwijs van belang zijn bij de selectie van programma's zoals bruikbaarheid, aanpasbaarheid. 


\section{Het jongerenonderzoek}

Het adviseren van scholen bij het vormgeven van schoolgezondheidsbeleid is de basis van de schoolslag-werkwijze. Om scholen op een goede manier te kunnen adviseren is kennis van groot belang. Naast kennis over preventieprogramma's zijn ook monitorgegevens over de gezondheidssituatie van de jongeren essentieel. Op basis van deze gegevens worden prioriteiten gesteld en beleid bepaald. ledere vier jaar wordt het jongerenonderzoek afgenomen onder alle leerlingen van klas 2 en 4 van het voortgezet onderwijs. Naast gemeentelijke rapportages en de rVTV, waarin de resultaten van het jongerenonderzoek zijn opgenomen, ontvangen alle scholen een eigen schoolrapport met een terugkoppeling van de resultaten van hun leerlingen. Deze schoolrapportage vormt een belangrijk onderdeel en startpunt van de schoolslag-werkwijze.

\section{Het schoolslag-stappenplan}

Om scholen te kunnen ondersteunen bij de invoering van schoolgezondheidsbeleid zijn zes schoolslag-stappen ontwikkeld. De schoolslag-adviseurs hebben een training gevolgd voor de toepassing van de stappen in de praktijk. Het schoolslag-stappenplan bestaat uit:

\section{Stap 1: Inventarisatie zorgbehoefte en lopende preventieactiviteiten}

Stap 1 legt de nadruk op het inzichtelijk maken van de meest voorkomende problemen op het gebied van gezondheid, welzijn en veiligheid en de reeds lopende preventieactiviteiten. Om goed aan te sluiten bij de unieke situatie binnen school is het nodig om eerst de huidige situatie van de school in kaart te brengen om zo de zorgbehoefte te bepalen. Hiervoor worden gegevens verzameld over gezondheid, welzijn en veiligheid van de leerlingen en de reeds lopende preventieactiviteiten op school.

\section{Stap 2: Bepalen prioriteiten}

Bij stap 2 gaat de school onder begeleiding van de schoolslag-adviseur - met advies van docenten, leerlingen en ouders - prioriteiten voor preventie en gezondheidsbevordering bepalen. $0 p$ basis van stap 1 zijn verschillende thema's en problemen in kaart gebracht. Echter, een school kan niet alles tegelijk aanpakken en zal daarom keuzes moeten maken. Deze keuzes moeten gedragen worden door alle geledingen binnen de school (personeel, leerlingen en ouders). Belangrijk is dat de gekozen prioriteiten geaccordeerd worden door de directie.

\section{Stap 3: Kiezen activiteiten}

Als de prioriteiten vaststaan, moet worden bepaald welke activiteiten en strategieën hier het beste bij aansluiten. Hierbij is het belangrijk om goed in beeld te hebben wat een school zelf al doet (resultaat stap 1) en waar verbetering en/of aanvulling gewenst is. Het Gezonde School Model kan behulpzaam zijn bij het zoeken naar passende activiteiten en strategieën. 
De schoolslagadviseur adviseert over mogelijke activiteiten en verwijst hierbij naar samenwerkingspartners en neemt eventueel deel aan overleg met relevante aanbieders. Bij meerdere aanbieders ondersteunt de schoolslag-adviseur bij het maken van een keuze, door van te voren vast te stellen wat de belangrijkste randvoorwaarden zijn voor de school. De school beslist uiteindelijk over de uit te voeren activiteiten.

\section{Stap 4: Opstellen schoolgezondheidsplan}

De gekozen activiteiten worden samen met de reeds lopende preventieactiviteiten vastgelegd in een schoolgezondheidsplan. De schoolslag-adviseur neemt initiatief tot het (mee)schrijven van het plan. In het plan staan per prioriteit afspraken over de activiteiten die worden ondernomen, voor welke doelgroep, door welke uitvoerder en met ondersteuning van welke organisatie (indien nodig). Bij voorkeur wordt het schoolgezondheidsplan ingepast in het totale school(zorg) plan en jaarplanning van de school. Voor het schoolgezondheidsplan is een format als voorbeeld beschikbaar.

\section{Stap 5: Uitvoeren plannen}

Veel activiteiten kunnen door de school zelf uitgevoerd worden. Indien nodig kan één van de organisaties die bij schoolslag betrokken zijn, ondersteuning bieden. Ook kan doorverwezen worden naar andere organisaties (afhankelijk van het gekozen aanbod). Voor een goede uitvoering van de plannen is betrokkenheid van de medewerkers een belangrijke voorwaarde. Daarvoor is een goede communicatie nodig binnen de school. Het is belangrijk dat medewerkers, leerlingen, maar ook hun ouders zien en liefst ook ervaren wat preventie op school inhoudt. Voor zowel de schoolslag-contactpersoon als de schoolslag-adviseur is het belangrijk de uitvoering van de plannen te volgen (procesmatig), zodat eventuele knelpunten in de uitvoering vroegtijdig gesignaleerd worden. Voortgang en planning kunnen besproken en gemonitord worden in overleg met preventieteam c.q. schoolslag-contactpersoon. De uitvoerder van de activiteiten of interventies is verantwoordelijk voor de inhoud.

\section{Stap 6: Evalueren en verankeren}

De geplande uitvoering van activiteiten wordt gevolgd en na afloop geëvalueerd (met alle betrokken doelgroepen). Er wordt gekeken naar het behalen van de beoogde resultaten en naar het totale proces inclusief de structuur, betrokkenheid en professionaliteit van de betrokkenen. De evaluatie levert gegevens op voor het opstellen of aanpassen van het preventieplan voor het nieuwe schooljaar. Haalbaarheid en uitvoerbaarheid zijn hierbij belangrijke criteria. De activiteiten die succesvol zijn kunnen verankerd worden in het schoolplan. Tevens worden de voorbereidingen getroffen voor de uitwerking van de volgende prioriteit (uit stap 2). Gegevens uit nieuwe monitorgegevens van de jeugd (jongerenonderzoek) kunnen inzichtelijk maken of er successen zijn geboekt op het niveau van risicogedrag bij leerlingen. 


\section{Internationale context}

Veel landen zijn bezig met het ontwikkelen van een werkwijze voor de invoering van schoolgezondheidsbeleid. Hieronder wordt een beschrijving gegeven van de verschillende werkwijzen. Daarna wordt een vergelijking gemaakt met de werkwijze in Nederland. Over het algemeen worden in de literatuur twee termen gebruikt wanneer het gaat over schoolgezondheidsbeleid, Health Promoting School (HPS) en Comprehensive School Health Program (CSHP). HPS is een initiatief van de WHO (WHO, 1993) en beschrijft drie domeinen van activiteiten die bepalend zijn. Ten eerste het curriculum gericht op gezondheid waarin kinderen kennis en sociale vaardigheden krijgen aangeleerd om een weloverwogen keuze te kunnen maken voor hun lichamelijke en psychosociale gezondheid. Ten tweede de omgeving van de school. En ten derde de interactie van de school met de omgeving / community. CSHP wordt in Amerika en Canada toegepast (Canadian Association for School Health, 1991) en gaat uit van de acht componenten zoals eerder beschreven in het Gezonde School Model van Marx en Wooley (1998). Beide modellen benadrukken dat een omslag in denken en handelen nodig is wat betreft de aandacht voor gezondheid binnen het onderwijs. Scholen zouden idealiter moeten overgaan van een klassikale aanpak van gezondheidsthema's naar een integrale aanpak, die zich richt op zowel de houding en het gedrag van de kinderen als op de leefomgeving, schoolomgeving en de interactie met de woon- en leefomgeving. Dit is de theorie; de literatuur toont aan dat de mate waarin de theorie in de praktijk wordt gebracht erg verschilt (Allenworth, 1995; Parsons, 1996; WHO, 1996; Stewart, 2000). Deschesnes en anderen (2003) hebben een review uitgevoerd naar hoe HPS en CSHP worden uitgevoerd met als doel meer inzicht te krijgen in de wijze waarop dit soort structurele benaderingen in de praktijk geïmplementeerd kunnen worden. Deschesnes benadrukt dat beide modellen nog te weinig worden toegepast in de praktijk om harde uitspraken te kunnen doen over de factoren die implementatie kunnen bevorderen. Toch zijn de ervaringen van beide werkwijzen veelbelovend. Op basis van het onderzoek worden vier condities beschreven die een positieve bijdrage leveren aan de implementatie. Deze vier condities zijn: 1. onderhandeling en coördinatie. 2. intersectorale actie. 3. politieke en financiële steun 4. evaluatie. Literatuur over het HPS concept benadrukt dat implementatie enkel slaagt met betrokkenheid van docenten, leerlingen, ouders en leden uit de community (WHO, 1999). In 2006 benoemen Barnekow en anderen participatie vanuit het onderwijs als belangrijkste element van schoolgezondheidsbeleid (2006). Lynagh (1997) beschrijft in een review van 86 preventieprogramma's dat geen enkel programma alle benoemde domeinen van een integrale aanpak heeft opgenomen. Marshall en anderen (2000) hebben een onderzoek uitgevoerd bij 27 scholen in Australië en ook hun resultaten tonen aan dat de scholen wel aandacht hebben voor preventieprogramma's, maar dat er geen sprake is van een integrale aanpak. 
In Amerika zijn er wel enkele scholen die alle acht componenten van het CSHP model implementeren, maar de verschillende activiteiten per component worden niet gecoördineerd, waardoor er in wezen geen sprake is van een integrale aanpak (Fetro, 1998). Ook recenter onderzoek van Brener en anderen (2001) en Kolbe en anderen (2001) laten dezelfde bevindingen zien. Door het ontbreken van een implementatie van de integrale aanpak is het onmogelijk harde conclusies te trekken over de mate van implementatie van integraal schoolgezondheidsbeleid op internationaal niveau. Niet alle ervaringen zijn gerapporteerd en de publicaties die beschikbaar zijn, zijn moeilijk onderling te vergelijken. In elk land wordt schoolgezondheidsbeleid op een andere manier vormgegeven. Wel kan op basis van de resultaten geconcludeerd worden dat ook op internationaal niveau nog gezocht wordt naar een goede strategie om de integrale aanpak van schoolgezondheidsbeleid geïmplementeerd te krijgen.

Wanneer we de Nederlandse opzet van schoolgezondheidsbeleid vergelijken met wat er gebeurt op internationaal niveau kunnen we stellen dat de basisprincipes van integraal werken vergelijkbaar zijn. Het gedachtegoed van het 'Healthy School Model' van Marx en Wooley (1998) komt terug in de verschillende benaderingen. Toch zijn de ontwikkelingen in Nederland zoals beschreven in dit proefschrift onderscheidend. Waar de overige landen zich beperken tot het gebruik van het 'Healthy School Model' is in Nederland een vervolgstap gezet door de ontwikkeling van het schoolslag-stappenplan. Dit stappenplan maakt het mogelijk om scholen niet alleen te wijzen op het belang van integrale aandacht voor de verschillende elementen van het Healthy School Model, maar ook aan te geven hoe dit stapsgewijs gerealiseerd kan worden. Tevens kan de begeleiding door een schoolslag-adviseur bijdragen aan een daadwerkelijke omslag naar integraal werken en denken om samen vorm te geven aan schoolgezondheidsbeleid. De Nederlandse opzet kan daarom een aanvulling op de reeds beschikbare internationale kennis bieden, met name aangaande implementatie. Internationaal is er nog weinig onderzoek gedaan naar de effectiviteit van een integrale aanpak. Om uitvoeriger onderzoek te doen naar de implementatie van schoolgezondheidsbeleid zoemen we in op de regio Zuid-Limburg.

Naast onderzoek naar de implementatie van de modellen zoals HPS en CSHP wordt onderzoek gedaan naar de relatie tussen gezondheid en leerprestaties. In Amerika wordt bijvoorbeeld het gedrag van jongeren gemonitord via het Youth Risk Behaviour Surveillance System (YRBSS). De data van deze monitor geven meer inzicht in de relatie tussen gezondheid en leerprestaties (Adams, 1995; CDC, 2007). Zo is aangetoond dat gezondheidsgerelateerde risicofactoren zoals lichamelijk en emotioneel misbruik, chronische ziekte en honger effect hebben op de schoolprestaties (Dunkle, 1991). Daarnaast toont onderzoek aan dat academisch succes een uitstekende indicator is voor het welbevinden van de jeugd en een voorspellende factor voor hun gezondheidstoestand als volwassenen (Vernez, 1999). Gezondheidsbevorderende schoolprogramma's uitgevoerd via het 'Healthy School Model' kunnen een positieve bijdrage leveren 
aan zowel de leerprestaties als het terugdringen van risicogedrag (Murray, Low, Hollis, Cross \& Davis, 2007). De resultaten van onderzoek in Amerika tonen effecten op twee mechanismen die ook bekend zijn uit de literatuur over sociaal-economische gezondheidsverschillen (Mackenbach \& van der Maas, 2010), namelijk sociale selectie en causatie. Bij causatie gaat het om de invloed van lage leerprestaties, evenals een lage sociaal economische status op gezondheid. Bij sociale selectie staat de invloed van ongezondheid op lage leerprestaties centraal (Adams, 1995; CDC, 2007).

Onlangs heeft Suhrcke (2011) in opdracht van de WHO een review uitgevoerd naar de invloed van gezondheid en gedrag op leerprestaties van jeugdigen tot 18 jaar in welvarende landen. Voor deze review zijn 53 publicaties meegenomen, veertig uit Amerika en negen afkomstig uit Europa; er zijn geen publicaties uit Nederland opgenomen. Op basis van de review kan geconcludeerd worden dat het aannemelijk lijkt dat er een relatie bestaat tussen gezondheid en leerprestaties. In de literatuur is geen consensus over de precieze mechanismen die bepalend zijn voor de correlatie tussen gezondheid en leerprestaties. Op basis van onderzoek van Grossman (1973), Cutler en Lieras-Muney (2006), Ding en anderen (2006) en Gan en Gong (2007) is een onderverdeling gemaakt van 3 mogelijke vormen van beïnvloeding: 1. leerprestaties beïnvloeden gezondheid 2. een of meer andere factoren beïnvloeden zowel gezondheid als leerprestaties 3. gezondheid beïnvloedt leerprestaties. Suhrcke stelt in de review dat er wel bewijs is voor correlatie, maar dat bewijs voor een causale relatie tussen leerprestaties en gezondheid of andersom ontbreekt (Suhrcke, 2011). Om de causale relatie aan te kunnen tonen is longitudinaal onderzoek nodig naar de effecten van gezondheidsbevorderende interventies. Het gaat dan om de effecten op gezondheid en leerprestaties en de volgtijdelijkheid ervan.

Dit type onderzoek is van groot belang om het relatieve voordeel van gezondheidsbeleid voor scholen inzichtelijk te maken. Wanneer het effect van gezondheidsbevordering op leerprestaties aangetoond kan worden is het aannemelijk dat dit voor de scholen als winst wordt beschouwd. Mocht dit het geval zijn dan kan het een belangrijk argument vormen in het overtuigingsproces voor de implementatie van schoolgezondheidsbeleid. Om die reden is ook de review zoals beschreven in hoofdstuk 1 uitgevoerd.

Ondanks alle initiatieven op internationaal en Europees niveau is er nog weinig onderzoek uitgevoerd naar de effecten op gezondheid en leerprestaties van een samenhangend schoolgezondheidsprogramma zoals bedoeld in de 'Healthy School' programma's die de afgelopen decennia zijn gestart (Stewart-Brown, 2006). Wel is aannemelijk gemaakt dat programma's verankerd moeten zijn, dus onderdeel moeten uitmaken van het reguliere schoolprogramma, omdat eventuele effecten zich pas op langere termijn, bij blijvende aandacht, zullen manifesteren. Om de effectiviteitsvraag te kunnen beantwoorden dient eerst onderzoek uitgevoerd te 
worden naar de mate van implementatie en verankering van schoolgezondheidsbeleid binnen het onderwijs. Om hier uitspraken over te kunnen doen is een samenhangende evaluatie naar de mate van implementatie van schoolgezondheidsbeleid in de lokale setting noodzakelijk (Stewart-Brown, 2006). Het onderzoek beschreven in dit proefschrift is hiervan een voorbeeld.

\section{De uitgangspositie voor het beschreven onderzoek}

In de periode van 2002-2005 was Leurs als schoolslag-coördinator verantwoordelijk voor de ontwikkeling en implementatie van de schoolslag-werkwijze in de regio Zuidelijk Zuid-Limburg. In deze periode heeft ze met inzet van vele partners aan zowel de zijde van het onderwijs als aan de zijde van het preventieveld een basis gelegd voor schoolgezondheidsbeleid binnen het onderwijs in Zuidelijk Zuid-Limburg en ook in de rest van Nederland (Leurs, 2008).

In samenwerking met het NIGZ is de schoolslag-werkwijze vanuit de regionale setting vertaald naar de landelijke Gezonde School Methode. Door middel van een, door GGD Zuid Limburg en het NIGZ ontwikkelde, Schoolslag Masterclass werden medewerkers van verschillende GGD'en verspreid over heel Nederland geschoold in de basisprincipes van de schoolslag-werkwijze en de vaardigheden die nodig waren om de werkwijze in te passen in de GGD-structuur en uiteindelijk te implementeren binnen scholen. Door ervaringen van diverse regio's werd duidelijk dat bij de invoering van de schoolslag-werkwijze ruimte moest zijn voor aanpassingen aan de lokale omstandigheden. In de andere regio's had de tijd niet stilgestaan en had men zelf al lop onderdelen) een eigen werkwijze in ontwikkeling die met de inzichten van de schoolslagwerkwijze werd aangescherpt. Mede hierdoor ontstond een grote diversiteit aan varianten van de schoolslag-werkwijze.

Voorafgaande aan de start van het in dit proefschrift beschreven onderzoek was in Zuidelijk Zuid-Limburg 5 jaar ervaring opgedaan met de implementatie van de schoolslag-werkwijze. Ten gevolge van een fusie in 2006 tussen de drie Zuid-Limburgse GGD'en werd het werkgebied verdrievoudigd.

GGD Zuid Limburg heeft een verantwoordelijkheid in het bevorderen van de gezondheid van de burgers in Zuidelijk Zuid-Limburg, Oostelijk Zuid-Limburg en de Westelijke Mijnstreek. Ten gevolge van de fusie werden de huidige programma's op kwaliteit getoetst en nieuwe keuzes voor de toekomst gemaakt. De schoolslag-werkwijze werd binnen dit proces gekozen als werkwijze voor heel Zuid-Limburg. In navolging van de landelijke implementatie van de schoolslag-werkwijze was GGD Westelijke Mijnstreek in 2004 al gestart met de invoering van de schoolslag- 
werkwijze. In Oostelijk Zuid-Limburg was nog geen ervaring opgedaan. Deze situatie vroeg om een nieuwe inventarisatie van de mogelijkheden en een kritische kijk op het proces. Met de komst van de Academische Werkplaats Publieke Gezondheid Limburg in 2005 (Jansen, Spreeuwenberg \& De Vries, 2005), een intensieve samenwerking tussen de gemeenten, Universiteit Maastricht en GGD Zuid Limburg, werd het mogelijk wetenschappelijk onderzoek uit te voeren in de praktijk. De beschreven situatie vormde een ideale start om de implementatie van de schoolslag-werkwijze in Zuid-Limburg nader te onderzoeken. Deze situatie was dan ook het uitgangspunt van het beschreven onderzoek.

\section{Het onderzoek}

\section{Relevantie}

Binnen scholen worden veel themaspecifieke projecten uitgevoerd gericht op de gezondheid van jongeren. Ook op wetenschappelijk niveau is veel onderzoek uitgevoerd naar de effecten van deze themaspecifieke schoolprogramma's. Voorbeelden hiervan zijn:

- Onderzoek van Aarnio en anderen (2002) naar de relatie tussen lichaamsbeweging en leerprestaties. Dit onderzoek toont aan dat er een relatie bestaat tussen lichamelijke beweging en leerprestaties.

- Onderzoek van Bellisle (2004) en Taras (2005) toont aan dat er een verband bestaat tussen ontbijtprogramma's op scholen en het stijgen van het concentratievermogen en het dalen van de vermoeidheid van leerlingen.

- Onderzoek naar een rookpreventieprogramma van Crone en anderen (2011) laat zien dat leerlingen, die op de basisschool lessen hebben gehad over de risco's van roken, in het voortgezet onderwijs een lagere intentie hebben om te gaan roken.

Ondanks de veelheid aan onderzoek gericht op effecten van themaspecifieke programma's is internationaal nog weinig onderzoek gedaan naar de structurele samenhang van preventieprogramma's zoals schoolgezondheidsbeleid.

In Zuid-Limburg is inmiddels verschillende jaren ervaring opgedaan met de invoering van schoolgezondheidsbeleid in het voortgezet onderwijs. Onderzoek naar de implementatie van de schoolslag-werkwijze in deze regio kan inzicht geven in de factoren die het proces positief dan wel negatief beïnvloeden. 


\section{Theoretisch kader}

Om de implementatie van schoolgezondheidsbeleid op een wetenschappelijke wijze te volgen is een theoretisch kader noodzakelijk. In deze paragaaf worden de implementatieprocessen in het algemeen en de implementatie van schoolgezondheidsbeleid in het bijzonder beschouwd in relatie tot een theoretisch kader.

Modellen over de implementatie van innovaties zijn door diverse onderzoekers beschreven. De bekendste is wellicht de Diffusion of Innovations theorie van Rogers (Rogers, 1995), waarin hij beschrijft hoe het verspreidingsproces van innovaties verloopt, welke rol communicatie hierin speelt en de werking van sociale systemen binnen dit geheel. Volgens deze theorie verloopt de verspreiding voor innovaties in vijf fasen: de kennisfase, de overtuigingsfase, de besluitvormingsfase, de implementatiefase en de bevestigingsfase. De snelheid waarmee een individu dit proces doorloopt is afhankelijk van persoonlijke eigenschappen. Rogers maakt hierbij onderscheid tussen vijf groepen: vernieuwers, snelle opvolgers, vroege meerderheid, late meerderheid en achterblijvers. Rogers benadrukt dat communicatie een belangrijke rol speelt bij het doorlopen van het verspreidingsproces. Hierbij gaat het om een tweezijdig interactieproces. Persoonlijke relaties en sociale netwerken spelen hierin een belangrijke rol. Naast de invloed van communicatie beschrijft Rogers vijf kenmerken van de innovatie zelf die bepalend zijn voor het welslagen van de invoering: relatief voordeel, inpasbaarheid, complexiteit, uitprobeermogelijkheden en zichtbaarheid van effecten.

De factoren die Rogers beschrijft zijn gericht op het verspreidingsproces van innovaties. Toch zijn sommige principes die Rogers beschrijft toepasbaar op de implementatie van schoolgezondheidsbeleid. Zo speelt bijvoorbeeld het relatieve voordeel van schoolgezondheidsbeleid een belangrijke rol bij de implementatie. Personen en instellingen zijn pas bereid een innovatie over te nemen wanneer ze denken er zelf voordeel van te zullen ondervinden. Bij de implementatie speelt de win-win factor een grote rol. Eerder is in de inleiding al aangegeven dat een duidelijke taakstelling voor scholen ontbreekt op het terrein van schoolgezondheidsbeleid. Wil de implementatie slagen dan is het van belang dat scholen het voordeel ervan in gaan zien. Waar Rogers spreekt over het verspreidingsproces staat in het beschreven onderzoek het implementatieproces van schoolgezondheidsbeleid centraal.

In 1997 vullen Oldenburg en anderen de oorspronkelijke lijst van Rogers aan met nog zeven kenmerken van de innovatie: invloed op sociale relaties, omkeerbaarheid, communiceerbaarheid, tijdsinvestering, het risico van de innovatie, commitment en de veranderbaarheid van de innovatie aan individuele wensen (Oldenburg, Hardcastle \& Kok, 1997). Aandacht voor deze factoren beïnvloedt het innovatieproces positief. Wanneer de schoolslag-adviseurs zich ervan be- 
wust zijn dat dergelijke factoren een rol spelen kan hiermee rekening worden gehouden bij de begeleiding van de school. Met name commitment is een factor die ook bij de implementatie van schoolgezondheidsbeleid een belangrijke rol speelt. De school dient zich eigenaar te voelen van het probleem, de gezondheidssituatie van de leerlingen, en bereid te zijn hierin te investeren. De schoolslag-adviseur is een groot deel van zijn/haar tijd bezig met het investeren in persoonlijk contact met de contactpersoon van de school en het verkrijgen van commitment voor de implementatie van schoolgezondheidsbeleid. Het relatief voordeel zoals beschreven door Rogers kan positief bijdragen aan dit proces van commitment verkrijgen.

In het model van Shediac-Rizkallah en Bone (1998) zijn community-projecten als focus genomen. Zij borduren voort op het werk van Rogers, maar beschrijven een raamwerk van factoren die van invloed zijn op de duurzaamheid van community projecten (Shediac-Rizkallah \& Bone, 1998). Zij zien duurzaamheid als een dynamisch proces waarin doelen en strategieën voortdurend aangepast moeten kunnen worden. Binnen dit proces wordt de uiteindelijke mate van duurzaamheid bepaald door factoren uit de community (socio-economische en politieke overwegingen, community participatie). Hierbij maken ze onderscheid tussen projectontwerp en implementatiefactoren londerhandelingsproces, effectiviteit, duur, financiering, projecttype en training) en factoren binnen de organisatorische setting (institutionele kracht van de organisatie, integratie met bestaande programma's en diensten, 'program champion' of leiderschap). Net als Rogers benadrukt ook dit model dat de community voordeel moet ondervinden van de betreffende innovatie. Het model is sterk gericht op effecten. Het is zaak dat de schoolslagadviseur de school als setting leert kennen en kennis heeft van de context specifieke factoren die een rol spelen bij het besluitvormingsproces van de school. Wanneer de schoolslag-adviseur in dit proces een win-win factor kan aandragen zal dat de implementatie ten goede komen.

In navolging van Rogers en Shediac-Rizkallah en Bone beschrijven Fleuren, Wiefferink en Paulussen (2004) de verschillende determinanten die een rol spelen bij innovaties, maar dan specifiek binnen de setting zorg. Zij maken net als Shediac-Rizkallah en Bone onderscheid tussen eigenschappen van de sociaal-politieke context en eigenschappen van de organisatie. Daarnaast voegen ze in navolging van Rogers de eigenschappen van de innovatie en eigenschappen van de gebruiker toe. Per factor wordt een uitgebreide lijst van determinanten genoemd (Fleuren en anderen, 2004). Schoolgezondheidsbeleid is een ander soort innovatie dan de zorginnovatie waarvoor het model is ontwikkeld. Wel laat het model zien hoe de verschillende factoren die een rol spelen bij innovatieprocessen vertaald kunnen worden naar een specifieke setting. Op onderdelen is dit ook mogelijk voor de implementatie van schoolgezondheidsbeleid. Net als de andere modellen benadrukken Fleuren en anderen het belang van draagvlak bij collega's en management. Draagvlak kan gecreëerd worden door de gebruiker het 
relatieve voordeel van de innovatie in te laten zien. De schoolslag-adviseur heeft een belangrijke rol in het overtuigen van de school van de meerwaarde van schoolgezondheidsbeleid voor het realiseren van hun onderwijsdoelen.

Alle drie de modellen geven aanknopingspunten op basis waarvan de implementatie van de schoolslag-werkwijze modelmatig kan worden gestructureerd. Echter, voor de toepassing van de verschillende modellen op de implementatie van schoolgezondheidsbeleid is enige ordening noodzakelijk. Het WIZ-model van de Werkgroep Integrale Zorg van de Universiteit Maastricht leek in deze ordening te voorzien (Mur-Veeman \& Van Raak, 1994; Ruland, Van Raak, Spreeuwenberg \& Van Ree, 2003; Van Raak, Mur-Veeman, Hardy, Steenbergen \& Paulus, 2003). Dit is een conceptueel kader voor bestuurlijke verankering van samenwerking in de zorg. Het model onderscheidt vier dimensies die invloed hebben op het realiseren van samenwerking: management, externe factoren, lokale context en mate van draagvlak. Elementen van het WIZ-model zijn toepasbaar voor de implementatie van schoolgezondheidsbeleid. Echter, het WIZ-model geeft onvoldoende inzicht in de ontwikkeling die een innovatie zelf doormaakt. Daarnaast is het model specifiek toegespitst op de zorg. Om die reden hebben Leurs, Mur-Veeman, Schaalma en De Vries (2003) bij de ontwikkeling van de schoolslag-werkwijze het WIZ-model als uitgangspunt genomen voor het Diagnosis of Sustainable Collaboration (DISC) model (zie figuur 4).

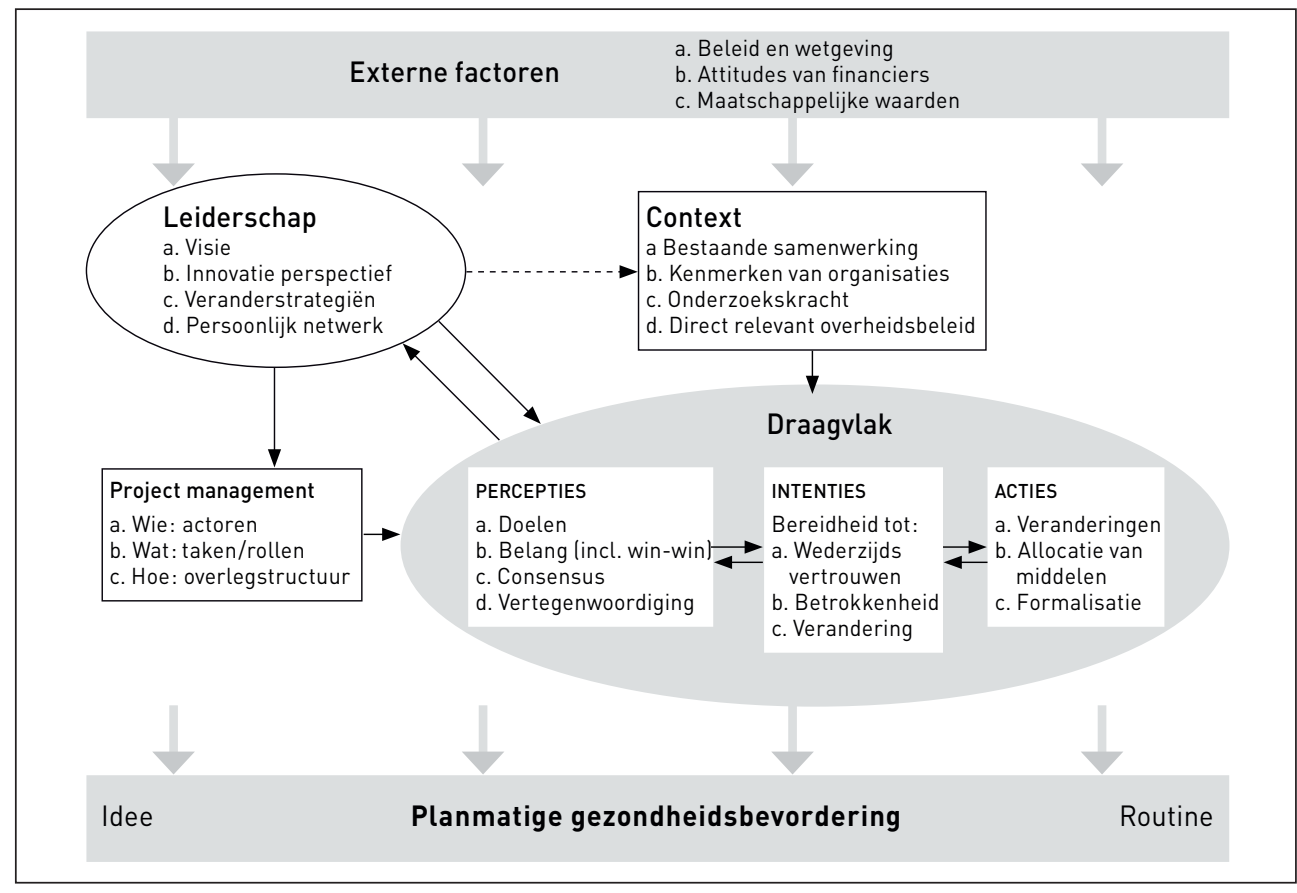

Figuur 4: Diagnosis of Sustainable Collaboration (DISC) model. 
Het DISC-model vertaalt de principes van het WIZ-model naar een model dat algemener inzetbaar is voor samenwerkingsprocessen op het terrein van integraal (gezondheids)beleid. Het DISC-model beschrijft de factoren die de overgang van eenmalige / projectmatige naar stabiele / routineuze / bestendige uitvoering beïnvloeden. Het betreft een tamelijk algemeen samenwerkingsmodel dat in het kader van dit onderzoek is toegepast op de setting school. Met behulp van het DISC-model kan een diagnose worden gesteld over hoever een bepaalde innovatie is doorgevoerd, in dit geval samenwerking op het terrein van integraal gezondheidsbeleid. Toepassing van het DISC-model geeft geen antwoord op de "hoe" vraag maar toont aan "waar" bijsturing wenselijk is om de kans op structurele verankering van de innovatie te vergroten. Bij de toepassing van het DISC-model op het centrale thema van dit proefschrift, de implementatie van de schoolslag-werkwijze, speelt het samenspel tussen enerzijds het onderwijsveld en anderzijds het veld van de preventieprofessionals een centrale rol.

Het onderzoek zoals beschreven in dit proefschrift borduurt voort op het werk van Leurs. Haar proefschrift beschrijft de ontwikkeling en toepassing van het DISC-model binnen het ontwikkelproces van de schoolslag-werkwijze (Leurs, 2008). In dit proefschrift wordt het DISC-model toegepast als diagnostisch model voor het in kaart brengen van de huidige mate van implementatie van de schoolslag-werkwijze en de belemmerende en bevorderende factoren die hierbij een rol spelen. Hieronder volgt een beschrijving van de belangrijkste factoren zoals deze in het DISC-model zijn beschreven. Een uitvoerige beschrijving van het DISC-model is opgenomen in het proefschrift van Leurs (Leurs, 2008).

\section{- Externe factoren}

Voor succesvolle samenwerking tussen instellingen, en vervolgens ook met de school, is het van belang de externe factoren die een rol spelen bij de samenwerking in kaart te brengen. Hierbij valt te denken aan de wet- en regelgeving waarvan de samenwerkingspartners afhankelijk zijn, maar ook de opstelling van de financiers ten opzichte van schoolgezondheidsbeleid.

\section{- Context}

Het is van belang inzicht te hebben in de context waarbinnen de innovatie vorm moet krijgen. Hierbij valt te denken aan reeds bestaande samenwerkingsverbanden, kenmerken van de organisaties en relevant overheidsbeleid.

\section{- Leiderschap}

Voor het slagen van structurele samenwerking is het van belang dat de leider een heldere visie uitdraagt die richting kan geven aan het proces. De strategieën die worden ingezet om samenwerking te realiseren dienen aan te sluiten bij de visie van de betreffende organisatie. 


\section{- Projectmatige samenwerking}

Er dient een duidelijke omschrijving te zijn van de drie centrale vragen: wie zijn de betrokken actoren? Wat is de verdeling van taken en rollen? Hoe worden deze taken en rollen door de betrokken actoren ten uitvoer gebracht?

\section{- Draagvlak}

Voor het creëren van draagvlak spelen drie componenten een belangrijke rol. Betrokken partijen nemen vanuit verschillende percepties deel aan de samenwerking. Ten eerste is het van belang dat zij tot afstemming komen van de verschillende belangen, wederzijdse voordelen vinden en tot consensus komen. Ten tweede dienen de betrokken partijen bereid te zijn elkaar te vertrouwen. Het is van belang dat de partijen betrokkenheid tonen. Ten derde zullen de betrokken partijen bereid moeten zijn acties te ondernemen om de verandering daadwerkelijk te kunnen realiseren.

Het DISC-model is een eclectisch model en bevat (varianten op) factoren van de modellen van Rogers (1995), Shediac-Rizkallah en Bone (1998) en Fleuren en Paulussen (2004) die van belang zijn voor de overgang van projectmatig samenwerken naar bestendiging. Doordat het DISCmodel de relevante factoren uit de verschillende modellen ordent lijkt het DISC-model voldoende toepasbaar voor het beantwoorden van de hierna beschreven onderzoeksvraag.

\section{Probleemdefinitie}

Scholen hebben de verantwoordelijkheid een klimaat te creëren waarin jongeren kennis op kunnen doen en zichzelf kunnen ontplooien. Uit onderzoek blijkt dat een gezonde leefomgeving bijdraagt aan de leerprestaties van jongeren (Stewart-Brown, 2006; Davis \& Cooke, 2007).

Binnen dit onderzoek is getracht inzicht te krijgen in de huidige onderbouwing van schoolgezondheidsbeleid en de wijze waarop en de mate waarin de implementatie van schoolgezondheidsbeleid in Nederland en in Zuid-Limburg in het bijzonder vorm krijgt.

\section{Onderzoeksvragen en methoden}

Dit proefschrift heeft tot doel een overzicht te geven van de belemmerende en bevorderende factoren die een rol spelen bij de implementatie van schoolgezondheidsbeleid. Gaat het onderwijs vol liefde aan de slag met gezondheidsbeleid of is de positie van gezondheidsbeleid binnen het onderwijs afgedwongen? Is er sprake van echte liefde of moeten we spreken van een verstandshuwelijk? De voornaamste onderzoeksvraag die binnen het beschreven onderzoek centraal staat is: 
“Wat zijn de bevorderende en belemmerende factoren voor de invoering van schoolgezondheidsbeleid middels de schoolslag-werkwijze?

Om deze vraag te kunnen beantwoorden zijn de volgende deelvragen geformuleerd:

1. Wat is bekend over de invloed van gezondheid op leerprestaties?

2. Op welke manier ondersteunen GGD'en in Nederland scholen bij het opstellen en uitvoeren van structureel schoolgezondheidsbeleid?

3. In welke mate is de schoolslag-werkwijze structureel ingebed in het beleid van de scholen voor voortgezet onderwijs in regio Zuid-Limburg?

4. Is de advisering van de schoolslag-adviseur van invloed op de invoering van structureel schoolgezondheidsbeleid bij scholen voor voortgezet onderwijs in de regio Zuid-Limburg?

5. Hoe kan de advisering van de schoolslag-adviseur bijdragen aan de invoering van structureel schoolgezondheidsbeleid bij scholen voor voortgezet onderwijs in de regio Zuid-Limburg?

6. Kan de schoolslag-checklist dienen als hulpmiddel om de kwaliteit van schoolse interventies te bepalen en de keuze uit het preventieaanbod eenvoudiger te maken?

Om de beschreven vragen te kunnen beantwoorden is een literatuurstudie verricht naar de wetenschappelijke onderbouwing van schoolgezondheidsbeleid. Daarnaast is de mate van implementatie van schoolgezondheidsbeleid in Nederland onderzocht. Om uitspraken te kunnen doen over de positieve dan wel negatieve factoren die het proces kunnen beïnvloeden, is gefocust op de invoering van de schoolslag-werkwijze in Zuid-Limburg. Het implementatieproces van de schoolslag-werkwijze in Zuid-Limburg is gedurende vier jaar gevolgd. Gedurende deze periode zijn verschillende onderzoeksmethoden gebruikt, zoals literatuurstudie, vragenlijst onderzoek, groepsinterviews, die alle hebben bijgedragen aan beantwoording van de onderzoeksvragen. Per artikel wordt de methode voor dat specifieke onderdeel van het onderzoek nader beschreven. 


\section{Opbouw van dit proefschrift}

Dit proefschrift bestaat uit zes artikelen. Het eerste deel van dit proefschrift richt zich op de wetenschappelijke onderbouwing/achtergrond van schoolgezondheidsbeleid. Hoofdstuk 1 geeft een overzicht van de belangrijkste onderzoeken die zijn uitgevoerd, gericht op de relatie tussen gezondheidsbevorderende activiteiten en leerprestaties. Wanneer we kunnen aantonen dat gezondheid de leerprestaties van leerlingen positief beïnvloedt draagt dit mogelijk positief bij aan het creëren van draagvlak voor de invoering van schoolgezondheidsbeleid.

In het tweede deel richt hoofdstuk 2 van dit proefschrift zich op de huidige positie van schoolgezondheidsbeleid in Nederland. Om de regionale resultaten te kunnen relateren aan de landelijke ontwikkelingen zijn alle GGD'en bevraagd over de wijze waarop zij scholen ondersteunen bij de vormgeving en uitvoering van schoolgezondheidsbeleid. Binnen het onderzoek is onderscheid gemaakt tussen vragen gericht op de procesmatige ondersteuning gebaseerd op de principes van de schoolslag-werkwijze en vragen gericht op de toepassing van de landelijke Gezonde School Methode. Het blijkt dat steeds meer regio's een eigen werkwijze hebben ontwikkeld om scholen te ondersteunen bij de invoering van schoolgezondheidsbeleid. Veel van deze werkwijzen zijn mede gebaseerd op de schoolslag-werkwijze zoals die ontwikkeld is in Zuid-Limburg.

In het derde deel van dit proefschrift ligt de nadruk op de implementatie van de schoolslagwerkwijze in Zuid-Limburg. Hoofdstuk 3 geeft een overzicht van de huidige mate van implementatie van de schoolslag-werkwijze bij scholen voor voortgezet onderwijs in de regio. Bij de oorspronkelijke opzet van het DISC-model speelde de samenwerking tussen de instellingen een belangrijke rol. In het beschreven onderzoek is het DISC-model als diagnostisch instrument gebruikt om te bepalen hoever de implementatie van de schoolslag-werkwijze binnen de betreffende scholen gevorderd is. Is er slechts sprake van een idee, is er sprake van regulier werk of bevindt de innovatie zich nog ergens in het midden van het innovatieproces zoals beschreven in het DISC-model? De mate van implementatie is bepalend voor de verdere handelingen. Om hier duidelijkheid over te krijgen zijn scholen en schoolslag-adviseurs bevraagd over de toepassing van het schoolslag-stappenplan in de praktijk. Hoe ver zijn ze, welke factoren werken bevorderend en welke belemmerend? Evaluatie van de huidige toepassing van de schoolslag-werkwijze in de praktijk is van belang om de werkwijze optimaal aan te kunnen passen aan de wensen en mogelijkheden van de onderwijsprofessionals. In hoofdstuk 4 staat de rol van de schoolslagadviseur centraal. De belangrijkste vraag die beantwoord dient te worden is de vraag of de schoolslag-adviseur van invloed is op de mate van implementatie van schoolgezondheidsbeleid bij scholen voor voortgezet onderwijs. Binnen deze samenwerking spelen zowel de persoonlijke begeleiding zoals de organisatorische competenties een belangrijke rol. Informatie over de 
mate van tevredenheid over competenties en begeleiding kan bijdragen aan de verbetering van de begeleiding van scholen bij de invoering van structureel schoolgezondheidsbeleid. De contactpersonen van de scholen hebben hiertoe vragen beantwoord over de mate van implementatie van het schoolslag-stappenplan, evenals de mate van tevredenheid over zowel de persoonlijke begeleiding als de organisatorische competenties van hun schoolslag-adviseur. Hoofdstuk 5 gaat dieper in op de wijze waarop de rol van de schoolslag-adviseur het beste vormgegeven kan worden. Hoe kan de begeleiding van de schoolslag-adviseur van invloed zijn op de implementatie van de schoolslag-werkwijze. Wanneer op basis van de resultaten uit hoofdstuk 4 bekend is of men tevreden is over de begeleiding van de schoolslag-adviseur en of dit bijdraagt aan de implementatie van de schoolslag-werkwijze, is het van belang te weten op welke wijze deze begeleiding het beste vormgegeven kan worden. Om deze vraag te kunnen beantwoorden zijn gesprekken gevoerd met de school die het verst was met de implementatie van het schoolslagstappenplan en de school die het minst ver was. Naast vragen over de begeleiding bij de implementatie van het stappenplan werden ook vragen gesteld over samenwerking. In dit hoofdstuk worden de belangrijkste factoren voor succes beschreven. In hoofdstuk 6 wordt de schoolslagchecklist geïntroduceerd. Dit is een meetinstrument voor het meten van de kwaliteit in termen van effectiviteit en toepasbaarheid van schoolse interventies. Dit hoofdstuk beschrijft een onderzoek naar een van de instrumenten die door de schoolslag-adviseurs worden ingezet bij de begeleiding van de scholen. Een belangrijke taak van de schoolslag-adviseur is het begeleiden van scholen bij de keuze van de juiste strategie en activiteit bij de gekozen prioriteit. Door het grote aanbod van interventies is dit geen eenvoudige taak. Deze checklist helpt de schoolslagadviseur bij de selectie van een interventie die past bij de behoefte van de school. Wanneer de schoolslag-adviseur in staat is de kwaliteit van preventieprogramma's te beoordelen, kan dit bijdragen aan een optimale advisering over de invulling van het schoolgezondheidsbeleid. Preventieprogramma's die goed aansluiten bij de wensen en mogelijkheden van de school zullen naar verwachting sneller structureel worden opgenomen in het schoolbeleid. Ten slotte geeft de discussie een reflectie op de beschreven onderzoekresultaten, wordt een vertaling van de onderzoeksresultaten gegeven naar de praktijk van alledag en worden aanbevelingen voor de toekomst gegeven. 
Deel 1 


\section{Onderbouwing voor schoolgezondheidsbeleid}





\section{Hoofdstuk 1:}

\section{Does school health promotion affect academic achievement?}

Ingediend als:

Pucher, K.K., Boot, N.M.W.M. en De Vries, N.K. (2010 (submitted)).

Does school health promotion affect academic achievement? 


\section{Summary}

The effects of school-based lifestyle interventions on standardized measures of academic performance and mediators of those effects were examined in a systematic review using strict methodological criteria. Only interventions targeting the maintenance of energy balance in primary school children were included. School health promotion interventions can have small to large positive effects on academic performance, whereas negative effects are unlikely. Effects of different kinds of interventions vary across academic domains. One physical activity (PA) intervention reported large effects of vigorous activity on mathematics performance; another PA intervention had small to medium impact on language scores. Smaller, but still considerable, effects were found for interventions combining nutrition and PA elements; one affected mathematics scores and another both mathematics and language scores. Slight improvements in language scores were observed for breakfast provision in schools. The reviewed studies suggest that effects might be sensitive to socioeconomic (SES) background. Our review did not allow definite conclusions concerning effect mediators. Most mediating processes were hypothetical assumptions made by authors on the basis of previous studies in experimental settings. Most of them related to healthier lifestyles among children. We conclude that schoolbased health promotion interventions can have positive effects on academic performance. 


\section{Introduction}

School-based health promotion programs are effective in improving the health status of schoolaged children (St. Leger and Nutbeam 2000; Stewart-Brown 2006). This has led to a huge growth in the availability of school health promotion interventions (Lister-Sharp, Chapman en anderen 1999) and initiatives to implement school-based interventions (Deschesnes, Martin en anderen 2003; Boot, van Assema en anderen 2010). There is also ample evidence for a positive relation between students' health status and their academic achievements (Resnick, Bearman en anderen 1997; Davis and Cooke 2007). This relation can partly be explained by differences in socioeconomic status (SES), parental characteristics, social influence, etc. (Hu, Lin en anderen 1998; Hanson and Austin 2003). The direct relation between effects of general health promotion interventions and academic achievement is much less clear.

Direct positive effects of mental health promotion and social and emotional learning interventions on academic performance have been shown (Greenberg, Weissberg en anderen 2003; DeSocio and Hootman 2004). DeSocio \& Hootman (DeSocio and Hootman 2004) explain these effects from the direct impact of mental health symptoms le.g. poor concentration, distractibility, sleepiness, etc.) on children's learning ability. Zins en anderen (Zins, Weissberg en anderen 2004) point at the impact of social relations and emotions on what and how children learn. Most mental health and social and emotional learning interventions are designed for specific risk groups or students with evident symptoms, rather than the general school population.

More general lifestyle interventions, e.g. those targeting physical activity (PA) levels and healthy diet, have a less obvious connection to learning and teaching. Nevertheless, several mediating processes have been suggested for a relation between academic performance and PA (Trudeau and Shephard 2010) and nutrition (Taras 2005). A review of school-based PA interventions (19662007) showed that increased opportunities for PA at school can enhance children's academic performance (Trudeau and Shephard 2008).

These findings provide preliminary evidence that school health promotion interventions may enhance children's academic performance, even when they are not specifically designed for children at risk or children with evident symptoms, or when they do not employ elements directly connected to school education. These findings also suggest that mechanisms relating to children's healthier lifestyle might mediate the effects of school-based interventions on academic performance. However, some studies in the above reviews were methodologically weak, the outcome measures of academic performance varied widely, and some studies focused on groups at risk rather than the general school population. In the present review we wanted to expand the available preliminary evidence by combining studies focusing on PA, nutrition and 
other health domains, restricting ourselves to methodologically sound designs (randomized controlled trials, cross-over controlled trials, quasi-experimental designs with pre- and posttest) using standardized measures of academic performance (e.g. grade-point averages or endof-year marks) to increase comparability between studies. To maximize the applicability of the interventions effects, we only included studies addressing general school populations. We report on the mediators that authors have suggested for the observed effects, to improve our understanding of the process that links lifestyle interventions to academic performance.

\section{Methods}

The literature search included two main strategies: an electronic search of the PubMed and PsycINFO databases and inspection of all reference lists of (selected) articles, reviews and dissertations generated from the databases. The electronic search was conducted on June 7, 2010. The search query included different descriptions of the outcome measure, encompassing synonyms of academic achievement and a diversity of titles of national examination tests, school grades and grade-point average (GPA). Secondary search terms related to the research population, research setting and the nature of the intervention. The entire search query is included in Appendix 1.

The selection process included two steps: titles and abstracts of articles were scanned for school-based health promotion interventions and full texts of relevant studies were evaluated with a standard form on final eligibility criteria (Figure 1).

During the full text examination, studies were excluded from the review if they did not report on a randomized controlled trial (RCT), quasi-experimental design, pretest-posttest controlled trial or cross-over control trial, or if they did not include individual school grades, results of national test examinations or GPAs as an outcome measure. Articles were also excluded when they reported on mental health interventions, social and emotional learning interventions or interventions designed for specific target groups (e.g. children at risk, disabled children, children diagnosed with asthma, epilepsy, ADHD, with behavioral problems, or other evident symptoms). We also excluded articles for which no full text was available (despite our requests to the authors) or repeated reports of interventions reporting identical outcomes, with identical measures on the same population.

The selection process was independently conducted by the first author and a research assistant. Disagreement was resolved by discussion. 


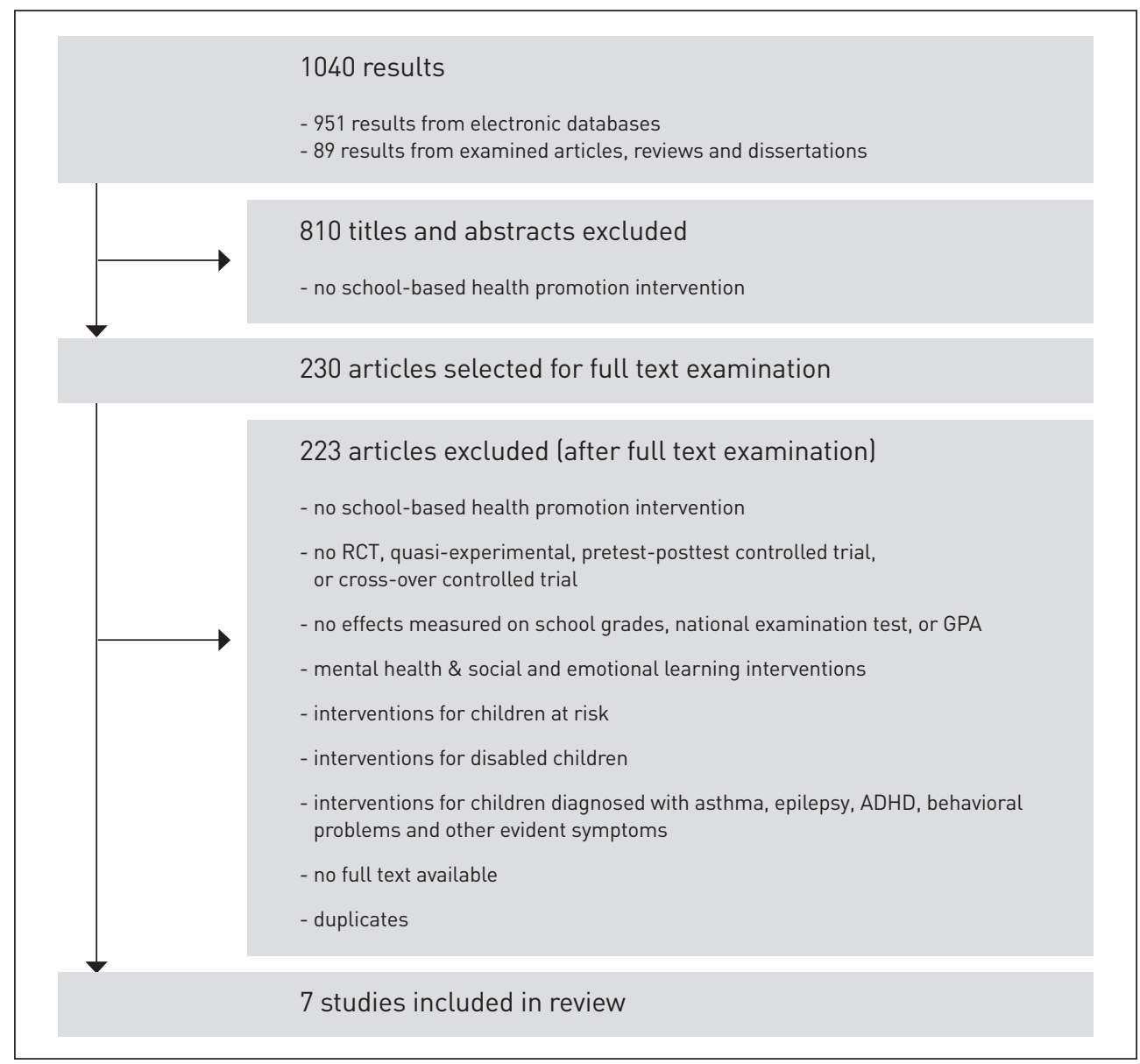

Figure 1: Selection process.

Three types of studies were identified: PA interventions, interventions which combined PA and nutrition elements and school breakfast programs (SBP). Information for the study description was extracted from the original article, and related to the country where the study was conducted, the main purpose of the intervention, research design, sample size, intervention, outcome measure, and effects on academic performance measures. Effects on other outcome measures than academic achievement are reported when they were used by authors to explain observed effects.

Cohen's d effect sizes (ESs) were calculated to indicate the magnitude of intervention effects. ESs were calculated for each academic achievement variable, using the reported means and 
standard deviations of the outcome measure at pre- and posttest and the sample size of the experimental group and the control group. If these data were not supplied, alternative methods were applied. ESs were only calculated when there were significant differences between conditions in terms of academic achievement measures. The effect sizes were interpreted based on Cohen's suggestion that $r=.10, r=.30$ and $r=.50$ represent small, medium, and large effects, respectively (Cohen 1988; Cohen 1992).

\section{Results}

\section{Effects of physical activity interventions on academic performance}

Table 1 lists the following studies investigating the effects of PA on academic achievement: Trois Riviéres (Shephard 1996); Sports, Play, and Activity Recreation for Kinds (SPARK) (Sallis, McKenzie en anderen 1999); Action Schools! British Columbia (AS!BC) (Ahamed, Macdonald en anderen 2007); and Physical Education (PE) Program (Coe, Pivarnik en anderen 2006). All interventions were delivered in the primary school setting (see tabel 1 on pages 50 - 53).

Trois Riviéres experiment: In the six-year Trois Riviéres experiment, Shephard (Shephard 1996) investigated the effects on academic performance of 60 minutes of daily physical education (PE) provided by a PE specialist at the expense of regular academic instruction, by comparing it to 40 minutes a week of usual PE classes by classroom teachers (control group). Although students spent 33 minutes a week less on instructions in mathematics, and no time was taken from English courses, the Trois Riviéres experiment had large positive effects ( $E S=0.75$ ) on students' Province Wide Examination (PWE) scores in mathematics, whereas controls were favored in terms of PWE scores in English. According to Shephard (Shephard 1996) 'the available data suggest that the rate of learning per unit of class time is enhanced in physically active students and that lack of curricular time is not a valid reason for avoiding daily PA.' (p. S35).

Authors' explanations: Shephard (Shephard 1996) found that improvements in academic achievement in the early stages of the Trois Riviéres experiment could be attributed to gains in cognitive and psychomotor functioning, but not those in the later stages when controls had compensated for their disadvantage in psychomotor functioning. Instead, Shephard suggests immediate arousal and relief from boredom, resulting in more attention at the end of the school day, as possible mediators between PA and academic performance.

Sports, Play, and Activity Recreation for Kinds (SPARK): In the two-year SPARK study, Sallis en anderen (Sallis, McKenzie en anderen 1999) investigated the effects on academic achievement of 3 times 30 minutes of PE a week and 30 minutes of self-management training, at the expense 
of other regular subjects (56-76 hours over a two-year span), provided by a trained teacher or a PE specialist, as compared with usual PE classes (control group). Participating schools were located in an affluent district with high baseline achievement scores. Pupils in the specialist condition had the lowest baseline scores on SES and achievement measures. The actual times spent on PE classes during an intervention week were 38, 65, 80 minutes in the control, trained teacher and specialist conditions, respectively. Decreases in academic performance over time were observed across all conditions. However, four of eight statistical comparisons showed an advantage for students in the experimental conditions, while only one of eight statistical comparisons favored the controls. MAT6 and later MAT7 reading, language and total battery scores decreased less in the experimental conditions than in the control condition. The trained teacher condition performed better on more scales than the specialist condition (6:2), but positive effects were observed on different scales in different cohorts. Sallis en anderen (1999) concluded that 'devoting substantially increased school time to health-related PE does not have detrimental effects on students' academic performance' (p. 134).

Authors' explanations: Sallis en anderen (Sallis, McKenzie en anderen 1999) concluded that PA is unlikely to be responsible for the smaller decrease in academic performance in the experimental conditions (trained teacher condition; PE specialist condition) since the largest effects were not found in the most physically active condition (PE specialist condition). Instead, they proposed the training that the teachers had received as a possible explanation for the larger effects in the less active group (trained teacher condition). This training might have taught teachers how to manage children in the PE setting and increased teachers' confidence in teaching PE. Both increased competence and confidence may have transferred to the teaching of other subjects. The authors attributed the overall decrease in academic performance across conditions to the high SES at the schools and high achievement scores at baseline. They also suggested that baseline differences in SES between experimental conditions might impact on the observed effects.

Action Schools! British Columbia (AS!BC): In the two-year AS!BC study, Ahamed en anderen (Ahamed, Macdonald en anderen 2007) examined the effects on academic performance of 15 minutes of daily classroom PA, administered by classroom teachers, in addition to a weekly 80 minutes of usual PE, compared with usual PE classes only (controls group). The ten minutes that teachers actually spent on classroom PA did not change academic performance significantly, but the intervention group caught up with the controls who had an initial advantage. The authors concluded that AS!BC increased PA but did not harm academic achievement, and therefore may 'be an attractive alternative for government and school administrators who aim to promote a school-based physical activity model' (p. 376). 
Table 1: Studies th at assessed effects on academ ie achievem ent (Continued on next page).

\begin{tabular}{|c|c|c|c|c|}
\hline Study & Country & Design & Sample & Intervention \\
\hline $\begin{array}{l}\text { Shephard et } \\
\text { al (1996) }\end{array}$ & $\begin{array}{l}\text { Québec, } \\
\text { Canada }\end{array}$ & $\begin{array}{l}\text { Pretest, } \\
\text { posttest, } \\
\text { controlled } \\
\text { trial }\end{array}$ & $\begin{array}{l}546 \text { 1st- 6th } \\
\text { graders } \\
\text { from one } \\
\text { urban } \\
\text { primary } \\
\text { school and } \\
\text { one rural } \\
\text { primary } \\
\text { school }\end{array}$ & $\begin{array}{l}\text { Trois Rivieres experiment A PE specialist provided one hour per } \\
\text { day of PE classes, emphasizing the learning of motor skilis in the } \\
\text { first two years, development of cardio-respiratory and muscular } \\
\text { endurance in the 3rd and 4th years, and the introduction of a } \\
\text { variety of sports in the last two years. Throughout the experimen- } \\
\text { tal period, PE classes included activities which maintained } \\
\text { students' heart rates at a sufficient level to induce cardiovascular } \\
\text { training through the entire PE class. In the control group, } \\
\text { teachers continued teaching PE for } 40 \text { minutes a week. }\end{array}$ \\
\hline
\end{tabular}

\begin{tabular}{|c|c|c|c|}
\hline $\begin{array}{l}\text { Sallisetal. } \\
\text { (1999) }\end{array}$ & $\begin{array}{l}\text { Southern } \\
\text { California }\end{array}$ & $\begin{array}{l}\text { Quasi-ex- } \\
\text { perimental, } \\
\text { randomiza- } \\
\text { tion of } \\
\text { schools; } \\
\text { stratification } \\
\text { of school } \\
\text { based on } \\
\text { ethnicity; }\end{array}$ & $\begin{array}{l}7544 \text { th } \\
\text { graders of } \\
\text { two } \\
\text { consecutive } \\
\text { years of } 7 \\
\text { elementary } \\
\text { schools }\end{array}$ \\
\hline
\end{tabular}

SPARK: In the PE program, students received $3 * 30$ min of additional $P E$ a week during 2 years, either provided by a certified PE specialist or a trained teacher, including 15 min of health fitness activities, which focused on the development of cardiovascular endurance and on strengthening of abdominal and upper body through 13 activities, and 15 minutes of skill fitness, which included 9 sports, promoting cardiovascular fitness and PA in children's community. In the weekly 30 min self-management program, students were taught skills to maintain a regular PA lifestyle. Methods used were topic-related presentations, goal-setting and creation of a reward system encouraging family participation. In 11 teacher training sessions, teachers were taught class management and instruction skills. PE specialists fulfilled an advisory role in coordinating space and equipment use and assisting with class scheduling etc.

\begin{tabular}{llll}
\hline $\begin{array}{l}\text { Ahamed et } \\
\text { al (2007) }\end{array}$ & British & Quasi- & 396 4th and \\
& Colombia & experimen- & 5th graders \\
& Canada & tal; & of 10 \\
& & Stratification & elementary \\
& of schools & schools \\
& by size & \\
& andgeograp- \\
& hic location; \\
& Randomiza- \\
& tion
\end{tabular}

AS!BC: Trained teachers provided 15 min daily ot classroom physical activities in addition to $80 \mathrm{~min}$ of regular PE classes a week. Children were exposed throughout the school day to a variety of activities including skipping, chair aerobics, hip hop dancing, playground circuits, and resistance exercise with exercise band. These activities were performed in the classroom, hallway or school playground. Parents were informed by school newsletter inserts. Teachers were taught during a 1-day course how to implement classroom activities. A AS!BC support team provided schools with resources such as written materials, classroom action bins etc. The AS!BC facilitator provided support on a weekly basis. Classroom physical activities made up one of six zones in the AS!BC program in which schools can integrate physical activities. The model is consistent with the concept of health promoting schools. The classroom physical activity was the most consistently implemented activity at schools.

\begin{tabular}{llll}
\hline $\begin{array}{l}\text { Coe et al } \\
\text { (2006) }\end{array}$ & Western & $\begin{array}{l}\text { Randomized } \\
\text { cross-over } \\
\text { controlled }\end{array}$ & $\begin{array}{l}214 \text { 6th } \\
\text { grade } \\
\text { students } \\
\text { trial }\end{array}$ \\
& USA & from 1 \\
& & public \\
& & middle \\
& & school
\end{tabular}

PE Intervention: Part of the sample receoived 55 minutes of physical education during the 1 st semester by physical education teachers, while the others received no physical education classes but were enrolled in alternative classes (e.g.: art, computer). The conditions were reversed in the second semester. Students' activity levels during PE classes were recorded by the System for Observing Instruction Time (SOFIT) and students' habitual physical activity by a 3-day physical activity recall.

\footnotetext{
$\mathrm{c}=$ control, $\exp =$ experimental group

${ }^{1}$ no exhaustive description of results provided in article. ES are taken from a review (Trudeau \& Shephard, 2007)

${ }^{2} \mathrm{c}=$ control, $\mathrm{t}=$ trained teacher condition, $\mathrm{s}=$ specialist condition
} 


\section{Outcome Measure}

Province-wide examinations administered at the end of 6th grade: French, Mathematics, English;

End of the year grades of 1 st through 6th grades: French, mathematics, English, natural science, combined score

\section{Effects}

Enhanced province-wide examination scores in mathematics, but lower scores in English for the experimental group.

\section{Effect Size}

Mathematics: 0.75 exp. $>c^{2}$

English language: 0.80 exp. $>c^{2}$

\section{Cohort 1:}

MAT6 administered in the $2 \mathrm{nd}$ and 5th grades: reading, mathematics, language, full battery score Cohort 2:

MAT6 administered in 2nd grade and MAT7 administered in the 6th grade: Reading, mathematics, language, full battery score

\section{Cohort 1: Enhanced language scores for} the specialist intervention group and enhanced reading scores for the teacher trained intervention group

Cohort 2:

Enhanced reading and total battery score but decreased language score for the trained teacher intervention. Greater increase of reading and total battery scores but lower increase in language score for the trained teacher intervention group than for the specialist intervention group.

\author{
Cohort $1^{2}$ \\ Language: $0.28 \mathrm{t}>\mathrm{c}$; \\ Reading: $0.36 \mathrm{~s}>\mathrm{c} 4$; \\ Cohort2 \\ Language: $0.28 \mathrm{~s}<\mathrm{c} \& 0.39 \mathrm{~s}>\mathrm{t}$ \\ Reading: $0.25 t>c \& 0.22 s>t$ \\ Total battery: $0.29 \mathrm{t}>\mathrm{c} \& 0.35 \mathrm{~s}<\mathrm{t}$;
}

CAT 3 administered in 4th and 5th grades (pretest) and 5th and 6th (posttest) grades: total standardized score for mathematics, reading, language / writing components
Baseline differences between intervention group and controls, with controls having better total standardized scores, were diminished at follow-up.

\section{exp. $=c$}

(n)


Table 1: Studies that assessed effects on academie achievement (Continued from previous page).

\begin{tabular}{|c|c|c|c|c|}
\hline Study & Country & Design & Sample & Intervention \\
\hline $\begin{array}{l}\text { Shilts et al. } \\
\text { (2009) }\end{array}$ & $\begin{array}{l}\text { Central } \\
\text { Valley, } \\
\text { California }\end{array}$ & $\begin{array}{l}\text { Experimen- } \\
\text { tal } \\
\text { cross-over } \\
\text { controlled } \\
\text { trial }\end{array}$ & $\begin{array}{l}84 \text { 6th } \\
\text { graders } \\
\text { clustered } \\
\text { in } 3 \\
\text { classrooms } \\
\text { of an } \\
\text { elemantary } \\
\text { school }\end{array}$ & $\begin{array}{l}\text { EatFit: The 5-week nutrition education intervention was } \\
\text { developed based on Social Cognitive Theory (SCT) and } \\
\text { intended to influence SCT constructs addressed during } 9 \\
\text { experimental lessons accompanied by a magazine-style EatFit } \\
\text { workbook, including the following topics: dietary and physical } \\
\text { activity goal setting, reading food labels, eating at fast food } \\
\text { outlets, learning physical activities and understanding media } \\
\text { influence. Methods used in the lessons were teaching skills, } \\
\text { goal performance feedback, behavior practice and motivation. } \\
\text { Students completed a dietary and physical activity web-based } \\
\text { assessment each week. Dietary analysis for example included } \\
\text { 24-hour diet record, personalized dietary feedback, goal } \\
\text { setting and contract. Raffle tickets and prizes were used to } \\
\text { motivate students. }\end{array}$ \\
\hline
\end{tabular}

\begin{tabular}{|c|c|c|c|c|}
\hline $\begin{array}{l}\text { Hollar et al. } \\
\text { (2010) }\end{array}$ & Florida, USA & $\begin{array}{l}\text { Pretest, } \\
\text { posttest, } \\
\text { controlled } \\
\text { trial }\end{array}$ & $\begin{array}{l}1197,6-13 \\
\text { year-old } \\
\text { children } \\
\text { from } 5 \\
\text { elementary } \\
\text { schools } \\
\text { qualifying } \\
\text { for free or } \\
\text { reduced- } \\
\text { price lunch }\end{array}$ & $\begin{array}{l}\text { HOPS: The dietary component included the modification of } \\
\text { school-provided breakfast, lunches and day snacks. Low-fiber } \\
\text { items, high-glycemic items and items with high amounts of } \\
\text { total saturated fats and trans fats were substituted by } \\
\text { healthier options. The curriculum component included a } \\
\text { nutrition and healthy lifestyle management program that } \\
\text { intended to teach children, parents and school staff about } \\
\text { good nutrition and benefits of physical activity. Teachers were } \\
\text { equipped with the Organ Wise Guys curriculum, which } \\
\text { included print books, print activity posters and physical activity } \\
\text { programs, to facilitate the integration of healthy lifestyle topics } \\
\text { in the curriculum. The PA component (WISERCISE) included } \\
10-15 \text { min of desk-side physical activities daily. The activities } \\
\text { were tailored to the core courses so that teachers could } \\
\text { continue their instructional lessons. Beyond this, schools were } \\
\text { asked to implement physical activity opportunities during } \\
\text { school breaks and encourage children, parents and school } \\
\text { staff to be physically active every day. }\end{array}$ \\
\hline
\end{tabular}

\begin{tabular}{|c|c|c|c|c|}
\hline $\begin{array}{l}\text { Meyers et al. } \\
\text { (1989) }\end{array}$ & $\begin{array}{l}\text { Massa- } \\
\text { chusetts, } \\
\text { USA }\end{array}$ & $\begin{array}{l}\text { Pretest, } \\
\text { posttest, } \\
\text { controlled } \\
\text { trial }\end{array}$ & $\begin{array}{l}1023 \text { 3rd - } \\
\text { 6th graders } \\
\text { of } 6 \\
\text { elementary } \\
\text { schools } \\
\text { qualifying } \\
\text { for free and } \\
\text { reduced- } \\
\text { price meals }\end{array}$ & $\begin{array}{l}\text { SBF: In } 1986 \text { the Commonwealth of Massachusetts enacted } \\
\text { legislation mandating the implementation of SBP in those } \\
\text { schools which were not offering SBP and in which } 40 \% \text { or } \\
\text { more of school lunches were served for free or at reduced } \\
\text { price. }\end{array}$ \\
\hline
\end{tabular}

\footnotetext{
$\mathrm{c}=$ control, exp $=$ experimental group

${ }^{1}$ no exhaustive description of results provided in article. ES are taken from a review (Trudeau \& Shephard, 2007)

${ }^{2} \mathrm{c}=$ control, $\mathrm{t}=$ trained teacher condition, $\mathrm{s}=$ specialist condition
} 


\section{Outcome Measure}

STAR Contents Standards revised administered in 6th grade (pre-, posttest): Language (listening, speaking), Mathematics (Algebra \& Functions 2.2/2.3, Statistics 1.1, Mathematical Reasoning 1.1),

Combined score

\section{Effects}

Enhanced language score and scores for the components algebra \& functions 2.3 and mathematical reasoning 1.1 for the intervention group.

\section{Effect Size}

Mathematical reasoning 1.1: 0.29 exp.>c; Algebra \& Function s 2.3: 0.45 exp.>c; Listening \& speaking: 0.57 exp.>c; Combined score: 0.33 exp. $>c$
FCAT administered in 3rd grade and at 1 year and 2 year posttest: reading, mathematics.
Enhanced math scores were found in the intervention group. Positive trends were visble for reading scores in the intervention schools.
Pre-test post-test:

Mathematics: 0.08 exp.>c;

Pre-test follow-up:

Mathematics: 0.46 exp.>c
CTBS administered in 3rd through 6th grades and at 3 month follow-up: language, reading, mathematics, combined score
Enhanced language and combined scores for students participating in the School Breakfast Program. Positive trends were observed in CTBS change scores tor reading and mathematics in SBP-participants.
Language: 0.19 exp.>c;

Total battery: 0.24 exp.>c; 
Authors 'explanations: Although the authors did not report on mediating processes, they did comment on SES, just like Sallis en anderen (Sallis, McKenzie en anderen 1999). They criticized the indirect assessment of SES through estimates of annual parental income in their own study, since SES can be an important marker of the academic standing of a school (cf. Alexander, Entwisle en anderen 2001)

Physical Education Intervention: In the PE intervention, Coe en anderen (Coe, Pivarnik en anderen 2006) investigated the effects of 55 minutes of daily PE classes provided during one semester by trained school teachers, comparing it with controls who received art and computer classes instead (controls group). Effects of habitual moderate and vigorous PA were also assessed. Additional PE, including an average of 19 minutes of moderate to vigorous activity, did not significantly compromise students' academic performance. Standardized test scores were $10 \%$ higher in the condition which was concurrently enrolled in the intervention (cross-over control trial). Increases in academic performance were associated with habitual vigorous PA, not with habitual moderate PA. The authors suggest that 'a potential role may exist for vigorous activity in physical education classes' (p.1519).

Authors' explanations: The authors presumed that the levels of moderate and vigorous PA during PE classes did not meet the necessary threshold to induce immediate arousal levels, improve motor skills or change body build. Just as arousal levels can increase attention and thereby facilitate learning, improvements in motor skills and changes in body build are positively linked to self-esteem, which has been shown to lead to better classroom behavior and the desire to learn (cf. Schendel 1965; Schurr and Brookover 1970; Teasdale, Sorensen en anderen 1992; Shephard 1996). The authors also commented on SES, which was not assessed in their study. Previous research had shown that SES is related to higher levels of PA and more sports participation in youth (cf. Raudsepp and Vira 2000; Santos, Esculcus en anderen 2004). SES may have acted as a major cause of academic performance, with PA acting as a mediator in this relationship.

Overall conclusion: Additional PA is not likely to affect academic performance negatively, even when provided at the expense of regular academic instructions, and regardless of whether it is employed as a class-room activity or as additional PE at high or low activity levels. Positive effects on academic performance have been demonstrated and are more likely when PE is employed at vigorous levels. Effects of the different PA interventions vary across academic domains. The proposed mediating processes for PA interventions on academic performance are improvements in psychomotor functioning, induced immediate arousal levels, long-tem effects on selfesteem and transfer of teachers' competencies learned during the training that teachers had received to other subjects. SES is also proposed as a possible moderator of the relation between academic performance and PA. 


\section{Effects of interventions combining physical activity and nutrition elements on academic performance}

Table 1 (on pages 50 - 53) lists studies investigating the effects on academic performance of a nutrition education program and an obesity prevention intervention, viz. the Eatfit intervention (Shilts, Lamp en anderen 2009) and the Healthier Options for Public Schoolchildren (HOPS) (Hollar, Messiah en anderen 2010) program, both delivered in the primary school setting.

Eatfit intervention: Shilts en anderen (Shilts, Lamp en anderen 2009) assessed the impact of 5 weeks of nutrition education, consisting of 9 educational lessons assisted by web-based assessment of dietary and PA behavior. In addition, $58 \%$ of the study sample were eligible for free or reduced-price lunches. The EatFit intervention had large positive effects on content standards in English and almost medium to almost large positive effects on content standards in mathematics. A medium-sized effect was observed on the total score of all content standards. The class with the highest academic scores at baseline improved least. Shilts en anderen (Shilts, Lamp en anderen 2009) concluded that the nutrition education intervention positively affects educational and health outcomes (Shilts, Horowitz en anderen 2009), 'thus serving a dual purpose for public schools' (p.130).

Author's explanations: Shilts en anderen (Shilts, Lamp en anderen 2009) did not report on mediators.

Healthier Options for Public Schoolchildren (HOPS): In the HOPS intervention, Hollar en anderen (Hollar, Messiah en anderen 2010) examined the effects of an obesity prevention program (including dietary, PA and curriculum components) on academic performance and healthy weight, one and two years after the intervention was implemented. Data for 350 of the 1197 children eligible for free or reduced-price lunch were available in the repeated-measure analysis of academic performance, against data for 645 children in the repeated-measure analysis of BMI. Children in intervention schools achieved higher FCAT math scores than controls at both measurements. A considerably larger effect on FCAT math scores was observed at two-year follow-up than at one-year follow-up, indicating a sleeper effect. Reading scores showed a positive trend in the intervention schools. HOPS also positively affected children's BMI, with more intervention children than controls remaining within normal BMI percentiles over the two years. Given that HOPS improved educational and health outcomes among children eligible for free or reduced-priced meals, the authors concluded that 'these findings are particularly encouraging given that many children from low-income backgrounds receive a significant proportion of their daily nutrition requirements at schools' in the USA (p. 652). 
Authors' explanations: The authors did not report on mediating processes.

Overall conclusion: There is strong evidence that nutrition education interventions and obesity prevention programs targeting dietary behavior and PA levels can positively affect the academic performance of primary school children. Even dual effects, on mathematics and language, are possible.

\section{Effects of free breakfast provision on academic performance}

Table 1 (on pages 50 - 53) lists one School Breakfast Program (SBP), which was delivered to primary school children.

School Breakfast Program (SBP): In the SBP study, Meyers en anderen (Meyers, Sampson en anderen 1989) examined effects on academic performance by comparing change scores of 335 SBP participants who attended breakfast on least $60 \%$ of the days at school with change scores of 668 SPB non-participants who did not attend school breakfast on any day in the three months after SBP was introduced (control group). SBP participants' gains in the CTBS total battery and CTBS language scores were greater than those of non-SBP participants. Positive trends were observed in CTBS change scores for reading and mathematics among SBP participants. The authors concluded that if these results can be confirmed by prospective controlled trials, SBP should be implemented on a larger scale.

Authors' explanations: The authors suggested immediate effects of morning meals eaten at the start of the school day, more long-term benefits relating to improved 24-hour dietary intake, or a combination of both, as possible explanations for academic improvements.

Overall conclusion: Breakfast interventions can slightly enhance academic performance. These effects might relate to immediate effects of meal intake or to long-term effects of 24-hour improvements in nutritional status. 


\section{Discussion}

We reviewed the evidence for effects of general lifestyle interventions on children's academic performance and the mechanisms researchers have proposed to account for these effects. We specifically focused on the effects on standardized measures of academic performance found in methodologically sound studies of interventions addressing healthy lifestyles in the general school populations. Although we initially found a large number of studies evaluating effects of school health promotion interventions on academic performance, very few had a methodologically sound design, assessed standardized measures of academic performance and targeted the general school population at the same time. These few school health promotion interventions exclusively addressed primary school children and targeted the maintenance of energy balance. Our review showed that interventions targeting PA levels (Shephard 1996; Sallis, McKenzie en anderen 1999), a combination of PA levels and healthy diet (Shilts, Lamp en anderen 2009; Hollar, Messiah en anderen 2010), or regular breakfast provision at school (Meyers, Sampson en anderen 1989) can have small to large effects on academic performance, whereas negative effects are unlikely. Effects of different kinds of interventions vary across academic domains. Large effects on mathematics were found for vigorous activity levels in one PA intervention (Shephard 1996), while another PA intervention had small to medium impact on language scores (Sallis, McKenzie en anderen 1999). Smaller, but still considerable, effects were found for interventions combining nutrition and PA elements; one affected mathematics scores (Hollar, Messiah en anderen 2010) and another both mathematics and language scores (Shilts, Lamp en anderen 2009). Slight improvements in language scores were observed for breakfast provision programs at school. Various authors acknowledged that their findings might be sensitive to the children's socio-economic background (Sallis, McKenzie en anderen 1999; Coe, Pivarnik en anderen 2006; Ahamed, Macdonald en anderen 2007).

In this review we also report on the mediators that authors suggested for the observed effects; regretfully, little evidence for possible mediators was provided. Instead, authors based hypothetical assumptions on previous studies in experimental settings. Mediators were proposed for PA interventions and the school breakfast program. It is not only mechanisms directly related to a healthier lifestyle, such as improved psychomotor skills (Shephard 1996; Coe, Pivarnik en anderen 2006), inducement of arousal levels (Shephard 1996; Sallis, McKenzie en anderen 1999; Coe, Pivarnik en anderen 2006), improved self-esteem (Shephard 1996; Coe, Pivarnik en anderen 2006), and nutritional balance (Meyers, Sampson en anderen 1989) which may be mediators of observed effects, but also indirectly related mechanisms like improved teaching practices. 
The findings of this review add to previous work by Trudeau and Shephard (Trudeau and Shephard 2008) about PA interventions simultaneously targeting healthy diets and PA levels, and a school breakfast program. We provide additional evidence that school health promotion does not necessarily have to target children at risk or with specific symptoms in order to generate effects on academic performance. Nor does it necessarily have to employ elements related to school education per se to produce academic gains, although it is likely that effects on academic performance might even be larger in those interventions. The single most important finding is that even general interventions targeting physical health may lead to improved academic performance. In addition, the findings show that the magnitude of effects and the academic subject in which effects occur vary with the intervention and the intervention domain, although no clear pattern emerged. The limited evidence regarding mediating processes makes further explanation of observed effects rather speculative.

The strength of this review is that we only report on the effects of methodologically sound studies into interventions. This limited the number of studies included but also allowed strong causal inferences about intervention effects. Another strength of this review is that we assessed the effects on standardized measures of academic performance, ensuring maximum generalizability. A third strength is that we examined the evidence of studies focusing on PA levels, studies combining nutrition and PA elements and studies involving daily breakfast provision at school, and calculated the effect sizes for each intervention. This gave us the opportunity to compare the effects between different lifestyle interventions.

The most important limitation, though inherently related to the strong aspects, of this review, is that we used strict inclusion criteria, so that many evaluations of school-based interventions with promising effects on academic performance had to be excluded. A very common reason for exclusion was that determinants of academic performance were assessed le.g. Wide Range Achievement Test, Digit Span Test, Wechsler Intelligence Test for Children, school attendance and behavior), rather than academic performance per se. Many of the excluded studies reported positive effects on the determinants of academic performance. It seems likely that where improvements on determinants of academic performance are possible, improvements in academic performance might be feasible too; although the relevant data were lacking in these studies. Another limitation of our review is that our conclusions are partly based on cross-over controlled trials, which are prone to maturation and testing biases and background learning. However, none of the reports on cross-over trials considered their results to be seriously threatened by these biases. 
Despite these limitations, this review shows that school health promotion targeting healthier lifestyles can positively affect academic performance in the general school population. Confirmation of these findings is urgently needed, as are studies among secondary school children and on interventions targeting tobacco and alcohol and drugs use. We also conclude that future studies should pay more attention to factors mediating the effects of health promoting interventions on academic performance. Similarly, interventions employing different theoretical methods and practical strategies should use outcome measures that allow better understanding of the contributions of individual intervention elements to educational outcomes. Finally, our review suggests that longitudinal changes in the observed effects (sleeper effects) can occur. This warrants long-term evaluations of school-based health promotion interventions.

Our review shows that even school-based interventions targeting physical aspects of health (PA and nutrition) can lead to improved scores on standardized measures of academic performance. 


\section{Appendix 1}

\section{PubMed}

\section{Search queries}

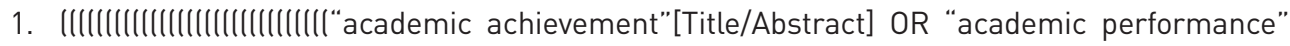
[Title/Abstract]) OR “academic functioning"[Title/Abstract]] OR “academic success"[Title/ Abstract]) OR “academic grade"[Title/Abstract]) OR “school grade"[Title/Abstract]) OR “educational performance"[Title/Abstract]) OR “educational functioning"[Title/Abstract]) OR "educational achievement"[Title/Abstract]) OR “learning performance"[Title/Abstract]) OR “learning achievement"[Title/Abstract]) OR “learning success"[Title/Abstract]) OR "scholastic performance"[Title/Abstract]) OR "scholastic achievement"[Title/Abstract]) OR "scholastic success"[Title/Abstract]] OR “academic growth"[Title/Abstract]) OR "vocabulary test"[Title/Abstract]) OR “test-scores"[Title/Abstract]] OR “examination mark"[Title/Abstract]) OR "test-score"[Title/Abstract]) OR "grade level"[Title/Abstract]) OR "grade point average"[Title/Abstract]) OR “GPA"[Title/Abstract]) OR "math achievement"[Title/Abstract]) OR “English achievement”[Title/Abstract]) OR “standardized reading"[Title/Abstract]) OR "class grade"[Title/Abstract]) OR "performance test"[Title/Abstract]) AND ("humans"[MeSH Terms] AND [English[lang] OR French[lang] OR German[lang] OR Italian[lang] OR Spanish[lang] OR Dutch[lang] OR Polish[lang]))) AND («((“"children”[Title/Abstract] OR “adolescent"[Title/Abstract]) OR “child”[Title/Abstract]) OR “pupil"[Title/Abstract]) OR "pupils"[Title/Abstract])

OR “student"[Title/Abstract]) OR “students"[Title/Abstract] AND (“humans"[MeSH Terms] AND [English[lang] OR French[lang] OR German[lang] OR Italian[lang] OR Spanish[lang] OR Dutch[lang] OR Polish[lang]) )) AND 《(《(“intervention"[Title/Abstract] OR "school intervention"[Title/Abstract]) OR "school health promotion"[Title/Abstract]) OR “classroom health education"[Title/Abstract]) OR "prevention intervention"[Title/Abstract]) OR "health education"[Title/Abstract]) OR "health promotion"[Title/Abstract] AND (“humans"[MeSH Terms] AND (English[lang] OR French[lang] OR German[lang] OR Italian[lang] OR Spanish[lang] OR Dutch[lang] OR Polish[lang]))] AND (“humans"[MeSH Terms] AND Journal Article[ptyp] AND (English[lang] OR French[lang] OR German[lang] OR Italian[lang] OR Spanish[lang] OR Dutch[lang] OR Polish[lang])]

2. («)(《(lintervention[Title/Abstract]) OR “school intervention”[Title/Abstract]) OR “school health promotion"[Title/Abstract]) OR classroom health education[Title/Abstract]) OR "primary prevention intervention"[Title/Abstract]) OR "health education"[Title/Abstract]) OR "health promotion"[Title/Abstract])) AND (l(ladolescent[Title/Abstract]) OR pupil[Title/Abstract]) OR child[Title/Abstract]) OR children[Title/Abstract]) OR student[Title/Abstract]]) 
AND (I(I["performance test"[Title/Abstract]) OR “math grade"[Title/Abstract]) OR "science grade"[Title/Abstract]) OR “English grade"[Title/Abstract]) OR “social study"[Title/Abstract]) OR mathematics[Title/Abstract]) AND (Journal Article[ptyp])

3. II(《)(lintervention[Title/Abstract]) OR “school intervention”[Title/Abstract]) OR “school health promotion"[Title/Abstract]) OR classroom health education[Title/Abstract]) OR "primary prevention intervention"[Title/Abstract]] OR "health education"[Title/Abstract]) OR “health promotion"[Title/Abstract])) AND (I(ladolescent[Title/Abstract]) OR pupil[Title/Abstract]) OR child[Title/Abstract]) OR children[Title/Abstract]) OR student[Title/Abstract])]

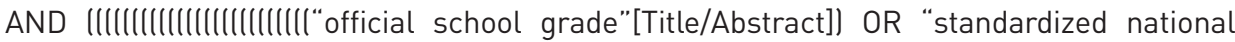
examination"[Title/Abstract]] OR “CAT"[Title/Abstract]) OR “Californian achievement test"[Title/Abstract]) OR “comprehensive assessment test"[Title/Abstract]) OR FCAT[Title/ Abstract]] OR “Florida comprehensive assessment test"[Title/Abstract]) OR “GCSE"[Title/ Abstract]) OR "general certificate of secondary education"[Title/Abstract]) OR "STAR"[Title/ Abstract]) OR “standardized testing and reporting"[Title/Abstract]) OR "province wide examination"[Title/Abstract]) OR “CTBS"[Title/Abstract]] OR "California test of basic skills"[Title/Abstract]] OR “SAT"[Title/Abstract]) OR "standard achievement test"[Title/Abstract]) OR “MAT6"[Title/Abstract]) OR “MAT7"[Title/Abstract]) OR “metropolitan achievement test"[Title/Abstract]) OR “student assessment test"[Title/Abstract]) OR “Stanford achievement test"[Title/Abstract]) OR “Terranova standardized test"[Title/Abstract]) OR “TERRANOVA"[Title/Abstract]) OR “EOG”[Title/Abstract]) OR “end-of-grade standardized test"[Title/Abstract]) AND (Journal Article[ptyp])

\section{PsycINFO}

\section{Search queries}

1. Abstract ( lacademic achievement) OR (academic performance) OR (academic functioning) OR (academic success) OR (academic grade) OR (academic test-score) OR (school grade) OR (educational performance) OR (educational functioning) OR (educational achievement) OR (learning performance) OR (learning functioning) OR (educational achievement) OR (learning performance) OR (learning functioning) OR (learning achievement) OR (learning success) OR (scholastic outcome) OR (scholastic outcomes) OR (scholastic achievement) OR (scholastic success) OR (academic growth) OR (vocabulary test) OR (academic competence learning capacity) OR (test-score) OR (examination mark) OR (student's overall GPA) OR (grade level) OR (GPA) OR (Grade-point average) OR (math achievement) OR (English achievement) OR (standardized reading) OR (class grade) OR (performance test) ) and Abstract ( (intervention) OR (school intervention) OR (school health promotion) OR (classroom health education) OR 
(primary prevention intervention) OR (health education) OR (health promotion) ) and Abstract ( (children) OR (adolescent) OR (pupils) OR (student) ) and health and Language: Dutch, English, German, Italian, Polish, Spanish; Age Groups: Childhood (birth-12 yrs), Preschool Age (2-5 yrs), School Age (6-12 yrs), Adolescence (13-17 yrs), Adulthood (18 yrs \& older), Young Adulthood (18-29 yrs); Population Group: Human, Male, Female

Limits: Language: Dutch, English, German, Italian, Polish, Spanish; Age Groups: Childhood (birth-12 yrs), Preschool Age (2-5 yrs), School Age (6-12 yrs), Adolescence (13-17 yrs), Adulthood (18 yrs \& older), Young Adulthood (18-29 yrs); Population Group: Human, Male, Female, Publication Type: All Journals

2. Abstract ( ('“math grade") OR (“English grade") OR (“science grade") OR (“mathematics") OR ("social study") OR ("performance test")) ) and Abstract ( (lintervention) OR ("school intervention") OR (“school health promotion") OR (“classroom health education") OR ("primary prevention intervention") OR ("health education") OR (“health promotion")] ) and Abstract ( (children) OR (adolescent) OR (pupil) OR (student) I and Abstract health and Language: Dutch, English, German, Italian, Polish, Spanish; Age Groups: Childhood (birth-12 yrs), Preschool Age (2-5 yrs), School Age (6-12 yrs), Adolescence (13-17 yrs), Adulthood (18 yrs \& older), Young Adulthood (18-29 yrs); Population Group: Human, Male, Female

3. Abstract ( ("official school grade") OR ("standardized national examination") OR ("CAT") OR ("Californian achievement test") OR (“GCSE") OR ("general certificate of secondary education") OR (“CTBS") OR (“california test of basic skills") OR (“SAT") OR (“standard achievement test") OR (“MAT6") OR (“metropolitan achievement test") OR (“MAT7") OR (“student assessment test") OR (“Stanford achievement test") OR (“Terranova standardized test") OR (“TERRANOVA") OR (“EOG") OR (“End-of- grade standardized test") ) and Abstract ( (intervention) OR ("school intervention") OR ("school health promotion") OR ("classroom health education") OR (“primary prevention intervention") OR (“health education") OR (“health promotion”) I and Abstract ( (children) OR (adolescent) OR (pupil) OR (student) ) and Language: Dutch, English, German, Italian, Polish, Spanish; Age Groups: Childhood (birth-12 yrs), Preschool Age (2-5 yrs), School Age (6-12 yrs), Adolescence (13-17 yrs), Adulthood (18 yrs \& older), Young Adulthood (18-29 yrs); Population Group: Human, Male, Female 

Deel 2 
Schoolgezondheidsbeleid in Nederland 



\section{Hoofdstuk 2:}

\section{De Gezonde School als methode voor GGD'en bij de invoering van schoolgezondheidsbeleid}

\section{Gepubliceerd als:}

Boot, N., De Jongh, D., Leurs, M., en De Vries, N.

De Gezonde School als methode voor GGD'en bij de invoering van schoolgezondheidsbeleid.

Tijdschrift voor Gezondheidswetenschappen 2011;89(4):222-28. 


\section{Samenvatting}

Sinds de ontwikkeling van de schoolSlag-werkwijze in 2002 en de landelijke 'vertaling' naar de Gezonde School neemt de aandacht voor planmatig schoolgezondheidsbeleid bij GGD'en in Nederland toe. Mede om deze ontwikkeling beter te stroomlijnen heeft het RIVM Centrum Gezond Leven (CGL) samen met partners de mate waarin GGD'en in Nederland scholen ondersteunen bij het vormgeven van structureel schoolgezondheidsbeleid in kaart gebracht. Dit onderzoek beschrijft welke activiteiten GGD'en in 2008 uitvoerden ter ondersteuning van scholen bij het vormgeven van schoolgezondheidsbeleid en welke belemmerende en bevorderende factoren ze binnen dit proces ondervonden. In totaal hebben medewerkers gezondheidsbevordering van 26 van de 30 in 2008 bestaande GGD'en een vragenlijst ingevuld en zijn bij zes van de 26 GGD'en verdiepende interviews afgenomen. De meerderheid van de GGD'en blijkt activiteiten uit te voeren die bijdragen aan structureel schoolgezondheidsbeleid. De ervaringen van de GGD'en zijn wisselend. Grote tijdinvestering en beperkt draagvlak bij GGD'en en scholen worden benoemd als belangrijkste belemmerende factoren voor succesvolle implementatie van schoolgezondheidsbeleid. Kansen liggen in het verbinden van onderwijsdoelen met publieke gezondheidsdoelen. 


\section{Inleiding}

Gezondere kinderen leren beter (Bos, De Jongh en anderen 2010; Fekkes and Paulussen 2010). Verschillende scholen besteden al aandacht aan gezondheid. Uit onderzoek is bekend dat het effect van gezondheidsbevorderende activiteiten op gezondheids- en onderwijsuitkomsten samenhangt met planmatigheid en structurele verankering in het schoolbeleid (Stewart-Brown 2006). Zo hebben veel scholen pestprotocollen en weerbaarheidstrainingen (Leurs, Bessems en anderen 2007). Vaak gaat het echter om oplossingen voor acute problemen in een klas waarbij planning en structuur ontbreken. In de periode 2002-2005 is - met ZonMw-financiering - in Zuid-Limburg de schoolSlag-werkwijze ontwikkeld. GGD Zuid-Limburg en NIGZ hebben deze werkwijze landelijk geïntroduceerd als de Gezonde School. Het betreft een systematische aanpak om scholen op vraaggerichte wijze te kunnen ondersteunen bij structureel schoolgezondheidsbeleid (Leurs, Jansen en anderen 2005). Deze werkwijze borduurt voort op het Amerikaanse Healthy School Model (Marx and Wooley 1998) met als uitgangspunt de samenhang tussen acht componenten gericht op gezond en veilig schoolklimaat, psychologische en sociaalemotionele ondersteuning, zorgaanbod, voedingsbeleid, sport en beweging, gezondheidseducatie, gezondheidsbevordering op de werkplek en ouder- en buurtparticipatie. Sinds de vertaling van het Healthy School Model (Marx and Wooley 1998) naar de Nederlandse situatie is de aandacht voor schoolgezondheidsbeleid in Nederland in een stroomversnelling geraakt (Bos, De Jongh en anderen 2010). Steeds meer GGD'en begeleiden, ieder op hun eigen manier, scholen bij het vormgeven van schoolgezondheidsbeleid (Dafesh, Buijs en anderen 2006).

In 2007 is het RIVM Centrum Gezond Leven (CGL) opgericht met als voornaamste taak het versterken van doelmatige, samenhangende en effectieve lokale gezondheidsbevordering. Binnen deze opdracht is de Gezonde School een van de aandachtspunten. De eerste doelstelling van CGL op het gebied van schoolgezondheid was in kaart brengen in welke mate GGD'en in Nederland scholen ondersteunen bij het vormgeven van structureel schoolgezondheidsbeleid. In dit artikel wordt een beschrijving gegeven van deze inventarisatie. In de beschreven studie stonden twee onderzoeksvragen centraal:

1. Welke planmatige activiteiten voeren GGD'en uit ter ondersteuning van basis- en/of voortgezet onderwijs scholen bij het vormgeven van schoolgezondheidsbeleid?

2. Wat zijn volgens GGD'en belemmerende en bevorderende factoren voor het ondersteunen van basis- en/of voortgezet onderwijs scholen bij het vormgeven van schoolgezondheidsbeleid? 


\section{Methode}

Het onderzoek is in 2008 uitgevoerd onder de contactpersonen Gezonde School van de 30 GGD'en die Nederland op dat moment rijk was. Deze contactpersonen zijn voornamelijk werkzaam als gezondheidsbevorderaar met een speciale focus op versterking van gezondheid van kinderen via de setting onderwijs. Het onderzoek bestond uit twee delen:

1. Kwantitatief onderzoek in de vorm van een vragenlijst voor de beantwoording van de eerste onderzoeksvraag.

2. Kwalitatief onderzoek in de vorm van diepte-interviews voor de beantwoording van de tweede onderzoeksvraag.

\section{Onderzoekspopulatie}

Alle GGD'en ( $n=30$ ) in Nederland hebben een vragenlijst ontvangen met het verzoek deze in te vullen en te retourneren. Medewerkers van CGL hebben voorafgaand de hoofden gezondheidsbevordering van deze GGD'en gebeld om hen te informeren over het onderzoek. Tevens is nagevraagd welke persoon binnen de GGD het meest betrokken is bij schoolgezondheidsbeleid. Het afnemen van de vragenlijsten gebeurde digitaal. In de begeleidende email is een internetlink opgenomen die de persoon doorlinkt naar de digitale vragenlijst. De termijn voor het invullen van de vragenlijst was twee maanden. Er is tweemaal een digitale herinnering gestuurd.

In totaal hebben zes diepte-interviews plaats gevonden bij medewerkers van GGD'en die scholen ondersteunen bij het vormgeven van schoolgezondheidsbeleid. De GGD'en zijn geselecteerd op basis van de resultaten van het vragenlijstonderzoek. Voor de diepte-interviews is specifiek gevraagd naar de persoon binnen de GGD die het meest betrokken is bij schoolgezondheidsbeleid.

\section{Vragenlijst}

De vragenlijst bestond uit 45 vragen en kon in 30 minuten worden ingevuld. De vragenlijst was gericht op de ervaringen met planmatige activiteiten die GGD'en uitvoeren ter ondersteuning van basis en/of voortgezet onderwijs scholen bij het vormgeven van schoolgezondheidsbeleid, bijvoorbeeld: "Voert u onderstaande activiteiten uit? Creëren van draagvlak voor schoolgezondheidsbeleid." (Ja, Nee). De totale vragenlijst is opgenomen in Tabel 1 (tabel 1 op pagina 72 en 73). 


\section{Diepte-interviews}

Via individuele diepte-interviews zijn de factoren die implementatie in het onderwijs belemmeren of bevorderen nader onderzocht. Hierbij is gebruikgemaakt van een vooraf opgestelde topic-list. De interviews zijn gehouden met professionals die deel hadden genomen aan het vragenlijstonderzoek. De interviews zijn afgenomen door twee medewerkers van landelijke thema-instituten en een medewerker van CGL.

\section{Dataverwerking en -analyse}

De statistische analyses zijn uitgevoerd met het programma SPSS 17.0. De transcripten van de interviews zijn geanalyseerd met behulp van het programma Nvivo 8 waarbij op basis van bevindingen uit eerder onderzoek (Boot, Van Assema en anderen 2010) de volgende hoofdcodes aan tekstdelen werden gekoppeld: bevorderende factoren: structuur, een aanspreekpunt en integrale karakter en belemmerende factoren: tijd, taakopvatting en draagvlak.

\section{Resultaten}

\section{Respons}

De vragenlijst voor het kwantitatieve onderzoek is toegestuurd aan 30 GGD'en. Met 26 ingevulde vragenlijsten bedroeg de respons $87 \%$.

\section{Hoe ondersteunen GGD'en schoolgezondheidsbeleid?}

In deze paragraaf worden de resultaten van het vragenlijstonderzoek beschreven (tabel 1 op pagina 72 en 73 ).

\section{Uitvoeren activiteiten gericht op schoolgezondheidsbeleid}

Een meerderheid van de GGD'en geeft aan de genoemde activiteiten uit te voeren. In verhouding tot de overige activiteiten wordt het begeleiden c.q. ondersteunen van prioriteitstelling door scholen door de minste GGD'en uitgevoerd. De meerderheid van de GGD'en die scholen ondersteunt bij het vormgeven van schoolgezondheidsbeleid voert vier of meer van de beschreven activiteiten uit die bijdragen aan het vormgeven van schoolgezondheidsbeleid.

Uit de ervaringen met de verschillende activiteiten die de GGD'en rapporteren blijkt voornamelijk het creëren van draagvlak, opstellen plan van aanpak, evalueren van activiteiten op school en de koppeling van individuele leerlingenzorg en collectieve preventie moeilijk uitvoerbaar in de praktijk. Een grote meerderheid van de GGD'en geeft aan positieve ervaringen te hebben met het in kaart brengen van de gezondheidssituatie en het uitvoeren van activiteiten en interventies op scholen. 
Tabel 1: Ervaringen van GGD'en met de ondersteuning van scholen bij schoolgezondheidsbeleid

\begin{tabular}{|c|c|c|}
\hline \multirow[t]{2}{*}{ Vraagstelling } & \multicolumn{2}{|c|}{$\begin{array}{l}\text { GGD-niveau } \\
\mathrm{N}=\text { wisselend }\end{array}$} \\
\hline & Totaal & $\mathrm{Ja}$ \\
\hline \multicolumn{3}{|l|}{ Voert u onderstaande activiteiten uit? } \\
\hline Creëren draagvlak schoolgezondheidsbeleid & 25 & 24 \\
\hline In kaart brengen van de gezondheidssituatie & 26 & 23 \\
\hline Bepalen van prioriteiten & 25 & 19 \\
\hline Bepalen van strategieën en activiteiten /opstellen van plan van aanpak & 24 & 21 \\
\hline Uitvoeren van activiteiten en interventies op scholen & 26 & 25 \\
\hline Evaluatie van activiteiten op school & 26 & 24 \\
\hline Koppelen van collectieve preventie aan individuele leerlingenzorg & 26 & 21 \\
\hline
\end{tabular}

Wat zijn uw ervaringen met het gebruik van de methode voor schoolgezondheidsbeleid bij onderstaande factoren?

\begin{tabular}{lrr} 
Creëren draagvlak schoolgezondheidsbeleid & 18 & 6 \\
\hline In kaart brengen van de gezondheidssituatie & 17 & 15 \\
\hline Bepalen van prioriteiten & 16 & 10 \\
\hline Bepalen van strategieën en activiteiten /opstellen van plan van aanpak & 14 & 6 \\
\hline Uitvoeren van activiteiten en interventies op scholen & 15 & 12 \\
\hline Evaluatie van activiteiten op scholen & 14 & 5 \\
\hline Koppelen van collectieve preventie aan individuele leerlingenzorg & 13 & 3 \\
\hline
\end{tabular}

Wat is de aanleiding geweest om met deze methode te werken?

\begin{tabular}{lcc}
\hline Opdracht vanuit de gemeente/regio & 21 & 3 \\
\hline Vraag vanuit de school & 21 & 2 \\
\hline Past binnen het beleid van de GGD & 21 & 14 \\
\hline Gebruiken graag bestaande methode & 21 & 9 \\
\hline Voert u onderstaande activiteiten uit? & 26 & 24 \\
\hline Adviseren van gemeente over activiteiten en interventies voor scholen & 26 & 19 \\
\hline Adviseren van gemeenten over schoolgezondheidsbeleid & 25 & 18 \\
\hline Ontwikkelen van een netwerk voor schoolgezondheidsbeleid & 25 \\
\hline
\end{tabular}


Tabel 1 (vervolg)

Vraagstelling

Nee, geen schoolgezondheidsbeleid

GGD-niveau

Ja, een aangepaste vorm van de Gezonde School

Wat is de reden waarom niet met de GSM wordt gewerkt?

We werken bewust via een andere methode voor schoolgezondheidsbeleid

We hebben onvoldoende informatie over de GSM

11

11

We hebben (vooralsnog) onvoldoende expertise in huis

11

11

11

Dit past niet binnen de opdracht van de gemeente

De GSM past niet in het beleid van de GGD

11

11

4

De GSM is onvoldoende uitvoerbaar

8

Hoe oordeelt u over de toepasbaarheid van de methode?

De methode is uitvoerbaar in de beschikbare tijd van de GGD 19

De methode is uitvoerbaar in de beschikbare tijd van de scholen

$16 \quad 2$

De methode sluit goed aan bij de organisatiestructuur van de GGD

De methode sluit goed aan bij de prioriteiten van de GGD

De methode sluit goed aan bij de prioriteiten van de scholen

De methode sluit goed aan bij de prioriteiten van de gemeente(n)

De methode is goed in te passen in de bestaande samenwerkingsverbanden met ketenpartners

De methode moet verder doorontwikkeld worden voordat hij goed toepasbaar is

Welke ondersteuning is een voorwaarde voor het uitvoeren van de methode?

Geen ondersteuning nodig

Ondersteuning bij het proces van uitvoering

21 12

Uitwisselen van ervaringen met andere GGD'en

21 15

Specifieke trainingen voor de verschillende activiteiten 


\section{Aanleiding schoolgezondheidsbeleid}

Een meerderheid van de GGD'en geeft aan dat ze werken aan schoolgezondheidsbeleid omdat dit past binnen het beleid dat de GGD heeft opgesteld voor gezondheidsbevordering binnen het onderwijs. Een meerderheid van de GGD'en geeft ook aan de gemeente te adviseren over schoolgezondheidsbeleid en over activiteiten en interventies voor scholen. Drie GGD'en zeggen gestart te zijn na een vraag vanuit de gemeente. Voor twee GGD'en was een vraag vanuit een of meer scholen de aanleiding.

\section{Toepassing Gezonde School}

Binnen zeven GGD'en wordt de Gezonde School werkwijze gebruikt om scholen te begeleiden bij het vormgeven van schoolgezondheidsbeleid. Acht GGD'en geven aan deze werkwijze te hebben aangepast aan de specifieke situatie in de regio. Vier GGD'en zeggen geen methode te gebruiken voor de begeleiding van scholen bij het vormgeven van schoolgezondheidsbeleid. Hiervoor worden verschillende redenen genoemd. Vijf GGD'en geven aan geen middelen te hebben om de methode goed toe te passen. Volgens vier GGD'en is de methode op dit moment onvoldoende uitvoerbaar. Tot slot geeft een enkele GGD aan onvoldoende informatie over de methode te hebben of bewust te werken met een andere methode.

Daar staat tegenover dat negen GGD'en die werken met de Gezonde School of een aangepaste vorm van de Gezonde School de methode uitvoerbaar vinden in de beschikbare tijd van de GGD. Een meerderheid van de GGD'en geeft aan dat de methode past bij de organisatiestructuur van de GGD en dat die aansluit bij de gestelde prioriteiten van de GGD en van de gemeente. Een meerderheid van de GGD'en vraagt zich af of de methode wel uitvoerbaar is in de beschikbare tijd van scholen.

\section{Ondersteuning}

Een meerderheid van de GGD'en geeft aan dat de methode verder ontwikkeld moet worden voordat hij goed toepasbaar is. Daarnaast geeft een meerderheid aan dat ondersteuning wenselijk zou zijn bij de invoering van de Gezonde School in hun eigen regio, dat ze meer ervaringen willen uitwisselen met andere regio's en dat er meer trainingen gegeven zouden moeten worden voor het vormgeven van schoolgezondheidsbeleid in de praktijk. 


\section{Belemmerende en bevorderende factoren voor het ondersteunen van schoolgezondheidsbeleid}

In deze paragraaf worden de resultaten van de zes gehouden diepte-interviews beschreven.

\section{Belemmerende factoren}

\section{Tijd}

Alle zes geïnterviewden benoemen tijd als de grootste beperkende factor om de Gezonde School te implementeren. Zij benadrukken dat hun GGD onvoldoende uren heeft of beschikbaar wil stellen om alle scholen structureel te kunnen begeleiden. Een geïnterviewde geeft als verklaring dat sprake is van een grote werkdruk. Met de gemeente zijn productafspraken gemaakt die nagekomen moeten worden. Hierdoor ontstaat een spanning tussen vraaggericht werken en aanbodgericht werken. Schoolgezondheidsbeleid kan bijvoorbeeld in het gedrang komen als GGD'en worden afgerekend op de daadwerkelijke uitvoering van themaspecifieke interventies.

“Knelpunten liggen vooral in de randvoorwaarden, zoals tijd en geld. Wie voert het uit en onder welke verantwoordelijkheid valt schoolgezondheidsbeleid, jeugdgezondheidszorg of gezondheidsbevordering... Maar het belangrijkste knelpunt is tijd."

Bij het benoemen van tijd als belemmerende factor wordt ook gewezen op de scholen. Vijf geïnterviewden geven aan dat ook scholen nauwelijks tijd hebben om over schoolgezondheidsbeleid na te denken. Ondanks de insteek dat de GGD scholen kan ondersteunen wordt het door scholen vaak gezien als een extra klus waar ze zelf in moeten investeren. GGD medewerkers geven aan dat scholen vaak niet aan schoolgezondheidsbeleid willen werken omdat zij hier, volgens de school, wettelijk geen taakstelling voor hebben.

"Scholen willen geen extra werk en denken dat schoolgezondheidsbeleid hen alleen maar extra werk oplevert. Het schoolprogramma ervaren ze al als extreem druk."

\section{Draagvlak}

Naast de beschikbaarheid van middelen speelt volgens de GGD'en ook draagvlak voor de werkwijze een belangrijke rol bij het implementeren van schoolgezondheidsbeleid. Dit geldt zowel intern bij de GGD als bij scholen. Alle zes geïnterviewde GGD-medewerkers geven aan dat schoolgezondheidsbeleid vraagt om interactie tussen zorg en preventie. Dit veronderstelt een 
samenwerking tussen de afdelingen jeugdgezondheidszorg en gezondheidsbevordering. Vier van hen geven aan dat de interne organisatie van de GGD vaak niet is ingericht op een planmatige en samenhangende werkwijze voor schoolgezondheidsbeleid. De invoering van schoolgezondheidsbeleid vraagt om een werkwijze gericht op advisering en begeleiding van scholen, zonder verplichte protocollen vanuit de ministeries van VWS en OCW. Het werk wordt mede bepaald door de vraag vanuit de school. Deze adviserende manier van werken sluit lang niet altijd aan bij de huidige structuur en competenties van de organisatie en specifieke afdelingen.

"Bedrijfsvoering binnen de GGD is nog niet ingericht op deze integrale aanpak voor schoolgezondheidsbeleid. Samenwerking tussen afdelingen verloopt soms moeizaam. Jeugdgezondheidszorg is te veel bezig met het primaire proces"

Naast het draagvlak bij de GGD wordt ook het draagvlak bij scholen door vijf GGD-medewerkers als knelpunt genoemd. Deze medewerkers geven duidelijk aan dat prioriteiten van scholen op andere vlakken liggen. Vanuit het oogpunt van de GGD kost het veel extra tijd om deze scholen gemotiveerd te krijgen voor schoolgezondheidsbeleid.

"Je hoort scholen zeggen, we moeten al zoveel. Dus dan komt dit er ook nog bij. Bij deze scholen hebben wij als GGD meer werk te verrichten om ze te motiveren, een stuk bewustwording, het belang en ook proberen aan te geven van: als je beleid maakt, dan heb je kans dat het over vier jaar echt beter is, terwijl als je nu gewoon los een keer een lespakket afneemt en je hebt daar een paar weken aandacht voor, dan zul je daar over vier jaar niets van terugvinden."

\section{Taakopvatting}

Het gebrek aan draagvlak bij scholen wordt door drie geïnterviewden gekoppeld aan de taakopvatting van scholen ten aanzien van schoolgezondheidsbeleid. De scholen ervaren niet dat gezondheid in algemene zin ook is opgenomen in de kerndoelen. Terwijl gezondheid wel naar voren komt in de domeinen van het voortgezet onderwijs "mens en natuur", "bewegen en sport" en de leergebieden van het basisonderwijs "oriëntatie op jezelf"en "bewegingsonderwijs". Bij het enthousiastmeren van scholen voor schoolgezondheidsbeleid krijgen GGD'en vaak 'nee' als antwoord. Het vergt dan ook veel uitleg en een positieve pers van een GGD.

“Scholen zien bepaalde thema's niet als hun taak (bijvoorbeeld voeding en beweging). Hierdoor worden prioriteiten anders gesteld." 


\section{Bevorderende factoren}

\section{Structuur}

Naast de belemmerende factoren worden door de GGD-medewerkers ook aanknopingspunten genoemd voor schoolgezondheidsbeleid. Een medewerker geeft aan dat door de tendens van aanbodgericht werken scholen vaak overladen worden met producten. Hierdoor zien ze door de bomen het bos niet meer en worden projectmoe. In twee andere interviews wordt dit bevestigd. De geïnterviewden geven aan dat scholen behoefte hebben aan structuur en een planmatige manier van werken, schoolgezondheidsbeleid kan structuur bieden.

“Scholen zijn projectmoe en dus zijn we op zoek naar een aanpak die gezondheidsbevor-

\section{Eén aanspreekpunt}

Twee geïnterviewden benadrukken het belang van samenwerking tussen de GGD en de school. Tijdens het interview met een van de GGD'en wordt aangegeven dat om op een goede manier structuur aan te brengen richting scholen het hebben van één aanspreekpunt binnen de school van groot belang is. Volgens de genoemde GGD zou de jeugdverpleegkundige deze rol prima kunnen vervullen. Zij komt veel op scholen, is een bekende voor de school en heeft een vertrouwensrelatie met de school. Dit zou een ideale uitgangssituatie kunnen zijn voor schoolgezondheidsbeleid.

"De jeugdverpleegkundige komt al op school, is een bekend gezicht, en bekend met interventies en de Gezonde School."

\section{Integraal}

Een goede implementatie van schoolgezondheidsbeleid vraagt om een organisatiestructuur waarin epidemiologie, gezondheidsbevordering, jeugdgezondheidszorg en beleid optimaal kunnen samenwerken. Dit betekent dat de vraaggerichte manier van werken in de hele werkwijze van de GGD wordt doorgevoerd en advisering in het kader van schoolgezondheidsbeleid als basisvoorziening wordt opgenomen in de begroting van gemeenten. 


\section{Discussie}

Met dit onderzoek werd beoogd in kaart te brengen in welke mate GGD'en in Nederland scholen ondersteunen bij het vormgeven van structureel schoolgezondheidsbeleid en welke factoren dit proces bevorderen dan wel belemmeren. Uit het onderzoek blijkt, dat een meerderheid van de GGD'en op planmatige wijze werkt aan de versterking van schoolgezondheidsbeleid.

De meerderheid van de GGD'en heeft moeite met het creëren van draagvlak bij scholen. Dit is een belangrijke constatering aangezien draagvlak een belangrijke voorwaarde is voor het planmatig werken aan schoolgezondheidsbeleid (Fleuren and De Jong 2006). Veel tijd en energie wordt gestoken in de werving, maar vaak blijkt deze investering achteraf tevergeefs wanneer een school niet ingaat op het aanbod. Een oorzaak van deze moeizame werving kan liggen in de wijze waarop scholen benaderd worden. Hierin wordt te weinig rekening gehouden met het verkrijgen van draagvlak en daarmee samenhangend de vraag van de school. Scholen kennen geen wettelijke verplichting om schoolgezondheidsbeleid op te stellen (SLO 2007; VO-raad and Ministerie van OC\&W 2008). Het ontbreken van de verplichting aan de preventieve kant leidt in combinatie met de vaak hoge werkdruk tot strikte keuzes en met regelmaat tot afwijzen van schoolgezondheidsbeleid. Toch zijn er voldoende redenen te noemen die het belang van schoolgezondheidsbeleid in het onderwijs benadrukken (Davis en Cooke 2007). Uit onderzoek is bekend dat gezonde leerlingen beter presteren dan ongezonde leerlingen (Stewart-Brown 2006; Fekkes and Paulussen 2010). Het hebben van schoolgezondheidsbeleid draagt dus wel degelijk bij aan de doelen van het onderwijs. Mogelijk zijn GGD-medewerkers nog onvoldoende in staat om in hun werving aan te sluiten bij de doelen van het onderwijs: betere leerprestaties, vooral in taal en rekenen. Om GGD'en beter te kunnen ondersteunen bij het vormgeven van schoolgezondheid is goed inzicht in de landelijke ontwikkelingen ten aanzien van onderwijs en gezondheid van belang. Zo kan een GGD bij het enthousiasmeren van scholen om Gezonde School te worden aansluiten bij de behoeften en recente ontwikkelingen in het onderwijs. De recent verschenen Handleiding Gezonde School (16) bevat hiervoor ook andere tips.

Uit het onderzoek blijkt dat veel GGD'en moeite hebben met het maken van een koppeling tussen collectieve preventie aan individuele leerlingenzorg. Deze koppeling vraagt om een goede samenwerking tussen de verantwoordelijke disciplines. Scholen zijn verplicht een zorgstructuur op te stellen. Deze structuur kan een belangrijke ingang vormen voor schoolgezondheidsbeleid. De kracht van planmatig schoolgezondheidsbeleid schuilt in de integrale samenwerking tussen alle betrokken disciplines waarin met één aanspreekpunt toegang wordt verkregen tot 
de expertise van alle samenwerkingspartners. Dit geldt zowel voor partners op het terrein van preventie als zorg (Leurs, Schaalma en anderen 2005). De komst van Centra voor Jeugd en Gezin (CJG) kan, door hun centrale positie, een belangrijke rol vervullen bij de koppeling van collectieve preventie en individuele leerlingenzorg (Van der Steenhoven and Van Veen 2009). Het is aan te raden het belang van gezonde scholen onder de aandacht te brengen bij de CJG's. Vanuit landelijk perspectief gebruikt CGL ervaringen uit de praktijk om de samenwerking met het Nederlands Centrum Jeugdgezondheid -NCJ (voorheen het RIVM Centrum Jeugdgezondheid) en het Nederlands Jeugdinstituut/NJi verder uit te bouwen ten gunste van de ondersteuning van CJG-professionals. Op lokaal niveau liggen er daarmee kansen voor GGD-professionals (JGZ en GB) om de samenwerking met de Centra voor Jeugd en Gezin te versterken. Het scholingsaanbod Onderwijs en Gezondheid van bijvoorbeeld de NSPOH is daarbij sterk aan te bevelen voor CJG-professionals.

GGD-medewerkers noemen vooral factoren als grote tijdinvestering, gebrek aan draagvlak bij scholen en bij GGD'en als oorzaak voor het niet slagen van de vormgeving van schoolgezondheidsbeleid. Dat enthousiastmeren, prioriteren van onderwerpen en het maken van realistische afspraken met alle partijen zo belangrijk is, is ook te zien bij het onderzoek naar de mate van implementatie op schoolniveau dat is uitgevoerd in Zuid-Limburg (Boot, Van Assema en anderen 2010). In dit onderzoek is gekeken naar de belemmerende en bevorderende factoren die scholen noemen voor de invoering van schoolgezondheidsbeleid in Zuid-Limburg. De uitgangspositie voor de GGD en het onderwijs verschilt. Waar de GGD verantwoordelijk is voor het proces en wordt afgerekend door gemeenten op het aantal scholen dat schoolgezondheidsbeleid heeft vormgegeven, worden scholen afgerekend door de onderwijsinspectie op de leerprestaties van hun leerlingen. Scholen zijn dus niet verplicht tijd vrij te maken voor schoolgezondheidsbeleid, terwijl de GGD van zijn gemeente(n) de opdracht kan ontvangen om schoolgezondheidsbeleid in te voeren binnen het onderwijs. Voor het slagen van schoolgezondheidsbeleid is het van groot belang dat de GGD'en handvatten krijgen die kunnen bijdragen aan de verbetering van de genoemde organisatorische factoren als tijd en geld. Op regionaal niveau betekent dit dat GGD'en duidelijke taakafspraken moeten maken met de gemeenten, waardoor ze enkel worden afgerekend op zaken waar ze invloed op hebben. Op regionaal én landelijk niveau is het nodig om de samenwerking met de onderwijssector te versterken. Als belangenbehartiger van GGD'en kan ook GGD Nederland zich sterker maken richting de politiek voor effectieve gezondheidsbevordering in het onderwijs. Een sterkere positie van gezondheid binnen de kwaliteitseisen van het onderwijs zou de invoering van schoolgezondheidsbeleid een stuk soepeler kunnen laten verlopen. Het is een van de taken van CGL om ook op dit terrein invulling te geven aan de hiervoor noodzakelijk geachte verbindingen. 
Een sterk punt van het uitgevoerde onderzoek was de combinatie tussen een vragenlijstonderzoek aangevuld met verdiepende interviews. Hierdoor kon doorgevraagd worden over de belemmerende en bevorderende factoren die GGD-medewerkers rapporteerden in het vragenlijstonderzoek naar vormgeving van schoolgezondheidsbeleid.

Voor dit onderzoek zijn de diepte-interviews enkel afgenomen bij GGD'en die werken aan schoolgezondheidsbeleid. Voor een vervolgonderzoek is het interessant om ook GGD-medewerkers die niet werken aan schoolgezondheidsbeleid te ondervragen, aangevuld met professionals van regionale partners en - wellicht nog belangrijker - contactpersonen aan de zijde van scholen. Dit geeft inzicht in de overwegingen van GGD'en om wel of niet met schoolgezondheidsbeleid te werken en hoe hun partners in preventie- en onderwijsland dit ervaren. Een dergelijk onderzoek biedt extra handvatten voor verdere versterking van de werkwijze waardoor de nu nog passieve GGD'en eerder tot ondersteuning van schoolgezondheidsbeleid overgaan.

Bij het onderzoek is geen onderscheid gemaakt tussen basis- en voortgezet onderwijs. We veronderstellen echter dat, doordat de werkzaamheden van de GGD vooral procesgericht zijn, de verschillen in belemmerende en bevorderende factoren bij ondersteuning van BO en VO minimaal zullen zijn. Toch is het interessant om bij een volgend onderzoek specifiek te vragen naar de ervaringen bij de afzonderlijke onderwijstypes, om zo de advisering specifiek aan te kunnen passen op de kenmerken van de doelgroep.

Geconcludeerd kan worden dat het merendeel van de GGD'en scholen in hun regio ondersteunen bij het vormgeven van schoolgezondheidsbeleid. Hierbij ervaren zij een aantal bevorderende en belemmerende factoren. De positie van schoolgezondheidsbeleid kan verder versterkt worden door de meerwaarde van gezondheidsbevordering voor de leerprestaties van leerlingen gerichter onder de aandacht te brengen van het onderwijsveld. Omgekeerd geldt dat de communicatie richting het public health-veld over de meerwaarde van de setting school voor de gezonde ontwikkeling van kinderen kan worden versterkt. Het CGL kan hierin - samen met zijn partners - een voortrekkersrol spelen. De resultaten van dit onderzoek zijn al gebruikt om de dienstverlening van CGL beter aan te passen aan de behoeften en mogelijkheden van de GGD'en en andere betrokken partnerinstellingen in de verschillende regio's. Zo is er een scholingsprogramma opgesteld in samenwerking met de NSPOH waarin handvatten worden bijgebracht om de rol als regisseur in het krachtenveld van onderwijs en gezondheid krachtiger neer te zetten. Ook geeft het CGL invulling aan een helpdeskfunctie via de website www.loketgezondleven.nl/ gezondeschool en telefonisch. Klapper op de vuurpijl is uiteraard de in 2010 verschenen Handleiding Gezonde School voor ondersteuners van het basisonderwijs (De Jongh, Bos en anderen 2010). 

Deel 3 


\section{Regionaal onderzoek}

naar schoolgezondheidsbeleid 



\section{Hoofdstuk 3:}

\section{Gezondheidsbevordering en voortgezet onderwijs: verstandshuwelijk of echte liefde?}

\section{Gepubliceerd als:}

Boot, N.M.W.M., Van Assema, P., Hesdahl, B., Leurs, M. en De Vries, N.K. Gezondheidsbevordering en voortgezet onderwijs: verstandshuwelijk of echte liefde? Tijdschrift voor Gezondheidswetenschappen 2010; 88:135-43. 


\section{Samenvatting}

De aandacht voor schoolgezondheidsbeleid in Nederland is gegroeid. Toch is nog weinig implementatie-onderzoek uitgevoerd. Tussen 2002-2006 is in de regio Zuidelijk Zuid-Limburg de schoolslag-werkwijze ontwikkeld, met als afgeleide de landelijke Gezonde School Methode. Schoolslag-adviseurs begeleiden scholen één op één bij het vormgeven van schoolgezondheidsbeleid.

Dit onderzoek beschrijft in hoeverre op dit moment sprake is van schoolgezondheidsbeleid in het voortgezet onderwijs in de regio Zuid-Limburg en welke factoren bevorderend danwel belemmerend zijn bij de implementatie van de schoolslag-werkwijze. Bestaande inzichten over de invoering van vernieuwingen zijn als conceptueel kader gehanteerd.

In totaal hebben 59 managementleden, 39 zorgcoördinatoren en 399 docenten, werkzaam bij 18 van de 25 scholen in de regio, een vragenlijst ingevuld. Op achttien scholen zijn groepsinterviews gehouden met de belangrijkste sleutelfiguren.

De invoering van schoolgezondheidsbeleid blijkt nog niet optimaal te zijn. Redenen als hoge werkdruk, ontbreken van gezondheidsbevordering als verplichting in de kerndoelen maar ook redenen gerelateerd aan de schoolslag-werkwijze worden genoemd. Wel voelen scholen zich verantwoordelijkheid voor de gezondheid van leerlingen.

Geconcludeerd wordt dat wanneer meer rekening wordt gehouden met de (on)mogelijkheden binnen het onderwijs, de schoolslag-werkwijze een goede vorm van begeleiding voor het onderwijs kan zijn bij het ontwikkelen en uitvoeren van schoolgezondheidsbeleid. 


\section{Inleiding}

Een goede gezondheid is een randvoorwaarde voor een goede kwaliteit van leven. Gezondheidsbevordering is gericht op het stimuleren van een gezonde leefstijl en daarmee op het verhogen van de kwaliteit van leven.(WHO 1986) Jongeren als groep zijn een belangrijke doelgroep voor gezondheidsbevordering. De school wordt door gezondheidsbevorderende organisaties gezien als een geschikte setting om deze doelgroep te bereiken.(Leurs 2005; Bessems. K. 2006; Leurs 2007) GGD'en en tal van andere regionale en landelijke partners hebben zich ten doel gesteld gezondheidsbevordering onderdeel uit te laten maken van het onderwijs.(Leurs 2005; Bessems. K. 2006; Leurs 2007)

Naast de stijgende aandacht voor schoolgezondheidsbeleid heeft de positie van zorg binnen het onderwijs een belangrijke ontwikkeling doorgemaakt.(Leurs 2008) Inmiddels heeft de zorg voor individuele leerlingen binnen het onderwijs een vaste plek verworven. Deze zorg is gericht op het signaleren, begeleiden en verbeteren van de problemen van risicoleerlingen. De afdeling Jeugdgezondheidszorg van de GGD werkt bijvoorbeeld intensief samen met het onderwijs door middel van periodieke gezondheidsonderzoeken.(Dijkstra 2004) Daarnaast worden scholen geadviseerd een zorgstructuur op te zetten waarbinnen de zorg voor individuele leerlingen samen met de belangrijkste ketenpartners wordt georganiseerd. De aanwezigheid van een dergelijke zorgstructuur wordt meegenomen bij de beoordeling van de kwaliteit van het onderwijs door de onderwijsinspectie. (Jeugdinstituut 2009) Op vrijwel alle voortgezet onderwijsscholen in Nederland is inmiddels een zorgcoördinator aangesteld die als taak heeft de zorgstructuur op te zetten en te onderhouden (Jeugdinstituut 2009).

Gezondheidsbevordering heeft echter nog geen vaste plaats binnen het onderwijs verworven, dit in tegenstelling tot leerlingenzorg. Scholen geven bij herhaling aan te vaak en door te veel verschillende instanties gevraagd te worden om gezondheidsbevorderende interventies uit te voeren waardoor ze door de bomen het bos niet meer zien. Ook vinden ze dat de aangeboden activiteiten onvoldoende aansluiten bij de kerndoelen.(SLO 2007) Gezondheidsbevordering is niet opgenomen in hun kerndoelen. Gesteld kan echter worden dat gezondheidsbevordering wel degelijk bijdraagt aan de realisatie van de kerndoelen.(Stewart-Brown 2006; Florence. M.D., Asbridge. M en anderen 2008; Chomitz. VR. 2009) Uit onderzoek is bekend dat gezondere leerlingen beter presteren dan ongezonde leerlingen.(Davis and Cooke 2007) Denk hierbij bijvoorbeeld aan de invloed van ontbijten op het concentratievermogen van leerlingen.(Bellisle 2004) Scholen hebben als taak om randvoorwaarden te realiseren waardoor de leerprestaties van leerlingen worden geoptimaliseerd. Gezondheid kan hieraan een bijdrage leveren. Nader onderzoek om deze relevantie te versterken, is wenselijk. 
Als reactie op de beschreven ontwikkelingen is in de periode 2002-2006 in de regio Zuidelijk Zuid-Limburg de schoolslag-werkwijze (noot a) ontwikkeld voor voortgezet onderwijs- scholen. (Leurs, Jansen en anderen 2002; Leurs, Schaalma en anderen 2005; Leurs, Steenbakkers en anderen 2006) Scholen worden door een eigen schoolslag-adviseur met behulp van het schoolslag-stappenplan begeleid bij het vormgeven van schoolgezondheidsbeleid (zie figuur 1). De schoolslag-adviseur wordt ingezet als makelaar namens de regionale gezondheidsbevorderende partners van scholen (GGD, welzijnswerk, GGZ en verslavingszorg) die daarvoor de handen in elkaar geslagen hebben. De schoolslag-adviseur is het directe aanspreekpunt voor de school op het terrein van preventie en is in dienst bij een van de regionale partners. Hier kunnen scholen met al hun vragen op het terrein van preventie terecht. De schoolslag-adviseur zorgt voor een terugkoppeling van vragen naar de betreffende partnerorganisaties, maakt een koppeling tussen de vraag van de school en het aanbod van de partnerorganisaties en adviseert over de inzet van producten en interventies van andere landelijke en lokale aanbieders. De werkwijze betreft een settingspecifieke toepassing van Intervention Mapping.(Leurs 2005; Bartholomew, Parcel en anderen 2006) Momenteel bevindt de schoolslag-werkwijze zich in de implementatiefase.

\section{Stap 1: Inventarisatie zorgbehoefte en lopende preventieactiviteiten}

Om de behoefte aan gezondheidsbevordering, preventie en zorg op een school te bepalen, is het allereerst van belang te weten hoe het is gesteld met de gezondheid en leefstijl van de leerlingen en welke preventieactiviteiten er al op school uitgevoerd worden. Een mogelijke bron hiervoor zijn de gegevens uit de Jeugdmonitor, uitgevoerd door de GGD in de 2e en 4 e klassen. Deze stap wordt uitgevoerd door het preventieteam, in het algemeen bestaande uit de zorgcoördinator, docent biologie, verzorging, lichamelijke opvoeding, ouders, leerlingen, en de schoolslag-adviseur.

\section{Stap 2: Bepalen van prioriteiten}

Op basis van de resultaten van stap 1 stelt de school (samen met het team van docenten, leerlingen, schoolslagadviseur en ouders) de prioriteiten vast voor preventie en gezondheidsbevordering.

\section{Stap 3: Kiezen van activiteiten}

Als de prioriteiten zijn vastgesteld, bepaalt de school - uiteraard terzijde gestaan door de schoolslag-adviseur - de daarbij passende activiteiten en strategieën.

\section{Stap 4: Opstellen van een schoolgezondheidsplan}

De resultaten die de school de komende jaren wil bereiken, leggen school en adviseur vast in een schoolgezondheidsplan. In het plan staan per prioriteit afspraken over de activiteiten die worden ondernomen: voor welke doelgroep, door welke uitvoerder en met ondersteuning van welke organisatie. Dit schoolgezondheidsplan wordt bij voorkeur ingepast in het totale schoolzorgplan.

\section{Stap 5: Uitvoeren plannen}

Veel activiteiten kan een school zelf uitvoeren. Vaak kan één van de schoolslag-partners ondersteuning bieden. Voor een goede uitvoering van de plannen is betrokkenheid van de docenten een belangrijke voorwaarde.

\section{Stap 6: Evalueren en verankeren}

Tussentijds en aan het eind van het schooljaar bekijkt de school samen met de schoolslag-adviseur of de geplande activiteiten het beoogde resultaat hebben opgeleverd. Op basis van deze evaluaties wordt het schoolgezondheidsplan voor het nieuwe schooljaar aangepast. De activiteiten die succesvol zijn gebleken, kunnen worden verankerd in het schoolzorgplan.

Figuur 1: Het schoolslag-stappenplan (Leurs, Steenbakkers en anderen 2006). 
De schoolslag-werkwijze wordt met financiering van de Zuid-Limburgse gemeenten nu ook als basiswerkwijze ingevoerd in de andere gebieden van de GGD-regio Zuid-Limburg, namelijk Oostelijk Zuid-Limburg en de Westelijke Mijnstreek. Om de doorontwikkeling van de werkwijze te kunnen waarborgen, vindt binnen de Academische Werkplaats Publieke Gezondheid ZuidLimburg begeleidend onderzoek plaats. (Jansen, Spreeuwenberg en anderen 2005) In dit artikel wordt een studie beschreven naar het verloop van de implementatie teneinde aanknopingspunten voor optimalisering ervan te vinden. In de studie stonden twee onderzoeksvragen centraal:

1. Wat is de mate van implementatie van de schoolslag-werkwijze binnen voortgezet onderwijs- scholen in Zuid-Limburg?

2. Wat zijn belemmerende en bevorderende factoren voor de implementatie van de schoolslagwerkwijze bij voortgezet onderwijs scholen in Zuid-Limburg?

Ten behoeve van de tweede vraagstelling zijn vooraf mogelijke belemmerende en bevorderende factoren die een rol spelen in de implementatiefase, in kaart gebracht op basis van het werk van Rogers, Fleuren en anderen, Marx en anderen en Shediac en anderen(Rogers 1995; Marx and Wooley 1998; Shediac and Bone 1998; Fleuren, Wieferink en anderen 2004) (zie figuur 2 op pagina 90). Hierbij werd in navolging van Fleuren(Fleuren, Wieferink en anderen 2004) een indeling in vijf categorieën gehanteerd: factoren gerelateerd aan de implementerende organisatie (school), bij de implementatie betrokken personen, de implementatiestrategie, de innovatie (de schoolslag-werkwijze) en de bredere maatschappelijke context (zoals overheidsbeleid).

\section{Methode}

Het onderzoek is in de periode februari-juni 2008 uitgevoerd onder managementleden, zorgcoordinatoren, schoolslag-adviseurs en docenten van de deelnemende voortgezet onderwijsscholen in Zuid-Limburg. Hierbij is gebruik gemaakt van twee verschillende vragenlijsten en semi-gestructureerde groepsinterviews.

\section{Onderzoekspopulatie}

Alle 25 voortgezet onderwijsscholen in de regio zijn gevraagd om deel te nemen aan het onderzoek. Negentien scholen waren hiertoe bereid. Eén school die deelname had toegezegd, trok zich bij de start van het onderzoek terug vanwege grote werkdruk. In totaal zijn 1807 vragenlijsten verzonden aan een selectie van alle medewerkers van de betreffende scholen, te weten 165 managementleden, 50 zorgcoördinatoren en 1592 docenten. Op achttien van de deelnemende scholen zijn interviews gehouden waarvoor het management, de zorgcoördinatoren en de schoolslag-adviseurs werden uitgenodigd. 


\begin{tabular}{|c|c|c|}
\hline Categorie & Factoren & \\
\hline Organisatie & $\begin{array}{l}\text { - Aantal potentiële gebruikers } \\
\text { - Acceptatie van schooldirectie en medewerker } \\
\text { - Bereidheid om de innovatie over te nemen } \\
\text { - Bevoegdheden, hiërarchische structuur } \\
\text { - Consistentie met de missie en visie } \\
\text { - Draagvlak } \\
\text { - Expertise } \\
\text { - Faciliteiten } \\
\text { - Functionele structuur } \\
\text { - Houding leidinggevende } \\
\text { - Interne organisatie } \\
\text { - Logistieke procedures } \\
\text { - Managementcapaciteit }\end{array}$ & $\begin{array}{l}\text { - Mogelijkheden om aan te sluiten bij be- } \\
\text { - } \text { staande structuren / programma's } \\
\text { - Mogelijkheden van de organisatie } \\
\text { - bij medeweid om informatie te verspreiden } \\
\text { - Onderstrepen van doel en gewenste } \\
\text { - } \text { - Organitaten } \\
\text { - Persoonlijke wisselingen in management } \\
\text { - Proces van besluit nemen } \\
\text { - Projectmanagement } \\
\text { - Samenwerkingscultuur } \\
\text { - Steun }\end{array}$ \\
\hline Persoon & $\begin{array}{l}\text { - } \text { Bereidheid om aan de innovatie deel } \\
\text { - } \text { te nemen } \\
\text { - Eigen effectiviteitverwachting } \\
\text { - Ervaren werkdruk } \\
\text { - Ethische problemen met de vernieuwing } \\
\text { - Kennis } \\
\text { - Ownership } \\
\text { - Persoonlijke eigenschappen }\end{array}$ & $\begin{array}{l}\text { - Steun van andere professionals } \\
\text { - Steun van collegae } \\
\text { - Steun van directie } \\
\text { - Steun van management } \\
\text { - Taakopvatting } \\
\text { - Toekennen van waardes aan de benoemde } \\
\text { behoeften } \\
\text { - Vaardigheden } \\
\text { - Verwachtingen }\end{array}$ \\
\hline Strategie & $\begin{array}{l}\text { - Administratieve ondersteuning } \\
\text { - Beschikbaarheid hulpmiddelen } \\
\text { - Beschikbaarheid van een kartrekker } \\
\text { - Beschikbaarheid van projectmanagement } \\
\text { - Beschikbare tijd }\end{array}$ & $\begin{array}{l}\text { - Betrokkenheid gezondheidsprofessionals } \\
\text { - Financiën } \\
\text { - Invoering gemakkelijker maken door training, } \\
\text { handleiding } \\
\text { - Vergoedingen }\end{array}$ \\
\hline Innovatie & $\begin{array}{l}\text { - Aanpassingsvermogen } \\
\text { - Benodigde training } \\
\text { - Bruikbaarheid } \\
\text { - Compatibiliteit } \\
\text { - Complexiteit } \\
\text { - Duidelijke omschrijving van het doel } \\
\text { - Duidelijke procedures en handleidingen } \\
\text { - Duidelijkheid } \\
\text { - Duur } \\
\text { - Effectiviteit } \\
\text { - Financiering }\end{array}$ & $\begin{array}{l}\text { - Frequentie } \\
\text { - Gebruiksgemak } \\
\text { - Helderheid } \\
\text { - Nut } \\
\text { - Observeerbaarheid } \\
\text { - Onderhandelingsruimte } \\
\text { - Relatief voordeel } \\
\text { - Risico's } \\
\text { - Soort project } \\
\text { - Triability } \\
\text { - Verwachte voordelen }\end{array}$ \\
\hline Maatschappij & $\begin{array}{l}\text { - Aanwezigheid infrastructuur } \\
\text { - Bewustwording van de gezondheidsvoordelen } \\
\text { - Financiële consequenties } \\
\text { - Participatie van de gemeenschap }\end{array}$ & $\begin{array}{l}\text { - Politieke overwegingen } \\
\text { - Psychische en emotionele schade } \\
\text { - Twijfels over de expertise van de professional } \\
\text { - Wet en regelgeving }\end{array}$ \\
\hline
\end{tabular}

* Sommige factoren kunnen in meerdere categorieën worden ingedeeld, daarnaast kan overlap tussen factoren binnen categorieën plaatsvinden.

Figuur 2: Mogelijke bevorderende en belemmerende factoren in de implementatiefase (Rogers 1995;

Marx and Wooley 1998; Shediac and Bone 1998; Fleuren, Wieferink en anderen 2004). 


\section{Vragenlijsten}

De vragenlijsten zijn gepretest bij twee zorgcoördinatoren van voortgezet onderwijsscholen in de regio om de terminologie zoveel mogelijk af te stemmen op de taal van het onderwijs. Op basis van de pretest is de term "gezondheidsbevordering" gewijzigd in "het bevorderen van gezondheid en veiligheid".

De vragenlijst voor managementleden en zorgcoördinatoren bestond uit 35 vragen en kon in 20 minuten worden ingevuld. Elke vraag had betrekking op de uitvoering van één van de stappen in het stappenplan, bijvoorbeeld "Is er op school een overzicht van activiteiten aanwezig?" (Ja, Nee, Gedeeltelijk, Niet van toepassing). In aanvulling hierop zijn in een vragenlijst voor docenten zes vragen gesteld over de betrokkenheid van de docent bij de werkwijze, bijvoorbeeld "Bent u betrokken geweest bij het opstellen van het schoolgezondheidsplan?" (Ja, Gedeeltelijk, Nee). Daarnaast zijn elf vragen gesteld over het belang dat de docent hecht aan bepaalde aspecten of stappen van de schoolslag-werkwijze, bijvoorbeeld "In hoeverre vindt u het belangrijk dat er binnen de school aandacht is voor preventie van gezondheid en veiligheid?" (vijf-puntschaal van 'zeer onbelangrijk' tot 'zeer belangrijk'). Het invullen van deze vragenlijst nam ongeveer tien minuten in beslag.

\section{Interviews}

In de groepsinterviews is gedurende gemiddeld negentig minuten gevraagd naar belemmerende en bevorderende factoren voor de implementatie van de schoolslag-werkwijze. De rapportage van de resultaten van het vragenlijstonderzoek diende als basis voor de interviews. Er zijn vragen gesteld ter bevestiging en/of verdieping van de conclusies. Daarnaast is gevraagd naar wensen voor de toekomst ten aanzien van schoolgezondheidsbeleid. De interviews vonden plaats op de scholen en zijn afwisselend gevoerd door de coördinator van schoolslag en het hoofd van de afdeling Gezondheidsbevordering van de GGD Zuid Limburg (derde auteur). De gesprekken zijn op band opgenomen en getranscribeerd.

\section{Dataverwerking en -analyse}

De antwoorden op de vragen aan de managementleden en de zorgcoördinatoren zijn samengevoegd tot twee categorieën: 'ja' versus 'nee, gedeeltelijk of n.v.t.'. Met behulp van Kruskall Wallis-testen is nagegaan of er verschillen waren tussen de managementleden en de zorgcoördinatoren. Hierbij is een significantieniveau van $5 \%$ aangehouden. $0 \mathrm{~m}$ uitspraken te kunnen doen over de implementatie van de stappen uit het stappenplan op schoolniveau, zijn de vragenlijsten van de zorgcoördinatoren apart geanalyseerd. 
Ook de antwoorden op de vragen aan de docenten zijn samengevoegd tot twee categorieën: '(zeer) belangrijk' versus 'neutraal of (zeer) onbelangrijk'; 'ja' versus 'gedeeltelijk of nee'.

De statistische analyses zijn uitgevoerd met het programma SPSS 14. De transcripten van de interviews zijn geanalyseerd met behulp van het programma NVivo 8 waarbij de volgende hoofdcodes aan tekstdelen werden gekoppeld: mate van implementatie, bevorderende of belemmerende factor, oordeel over belang, eigen betrokkenheid en wensen voor de toekomst. De codering van de kwalitatieve onderzoeksgegevens is ter controle door twee personen uitgevoerd.

\section{Resultaten}

\section{Respons}

De totale onderzoeksgroep ( $\mathrm{n}=497$ ) bestond uit 59 managementleden (respons 36\%), 39 zorg coördinatoren (respons 78\%) en 399 docenten (respons 25\%), werkzaam bij achttien scholen. Op alle achttien deelnemende scholen is een groepsinterview afgenomen. Het aantal participanten per interview varieerde tussen twee en zeven. In totaal namen 25 managementleden, 17 zorgcoördinatoren en alle 14 schoolslag-adviseurs aan een interview deel.

\section{Mate van implementatie}

Tabel 1 en 2 geven weer in hoeverre er sprake is van implementatie van de diverse stappen in de schoolslag-werkwijze. De eigen betrokkenheid van docenten bij de uitvoering van alle ondervraagde aspecten van de werkwijze is zeer minimaal $(<5 \%)$.

Stap 1: Inventarisatie zorgbehoefte en lopende preventieactiviteiten

Bij de meeste scholen is er aandacht voor gezondheid en veiligheid en is een preventieteam samengesteld om zorgbehoeften en lopende preventieactiviteiten te inventariseren. Ruim de helft van de scholen heeft een overzicht van de huidige preventieactiviteiten. Vrijwel alle ondervraagde docenten vinden het belangrijk dat er aandacht voor gezondheid is binnen de school.

Stap 2: Bepalen prioriteiten

Op vrijwel alle scholen worden prioriteiten voor gezondheidsbevordering bepaald. Dit gebeurt vooral op basis van onderzoek (de jeugdmonitor (noot b) en teamoverleg en in enkele gevallen 
op basis van de meningen van ouders en leerlingen. De meeste docenten vinden inspraak van medewerkers belangrijk bij het stellen van prioriteiten. De inspraak van ouders en leerlingen bij de prioritering wordt door ongeveer de helft van de docenten van belang geacht.

\section{Stap 3: Kiezen van activiteiten}

Op acht scholen is een themawerkgroep aanwezig en worden activiteiten onderling afgestemd. Voor een passend aanbod werken vrijwel alle scholen samen met de GGD. Daarnaast werken de meeste scholen samen met het welzijnswerk, de geestelijke gezondheidszorg en Bureau Halt. Minder dan de helft van de scholen werkt samen met verslavingspreventie. Aanvullend bleek uit de interviews dat er verschillende activiteiten worden uitgevoerd, maar dat het hierbij vaak gaat om losse activiteiten op klasniveau of om meerdere activiteiten die verenigd worden in een themaweek, georganiseerd in samenwerking met de schoolslag-adviseur.

Stap 4: Opstellen schoolgezondheidsplan

Op vijf scholen is een schoolgezondheidsplan aanwezig. Deze plannen blijken niet alle elementen van het schoolslag-stappenplan te bevatten. Er is geen beschrijving van onderzoeksresultaten en prioriteiten worden niet vermeld. Op zes scholen is er inspraak (geweest) van medewerkers, ouders en leerlingen bij het opstellen van het schoolgezondheidsplan. Meer zorgcoördinatoren (24\%) dan managementleden $19 \%$ ) gaven aan dat leerlingen hierbij worden betrokken. Op een enkele school na is het schoolgezondheidsplan niet bekend bij medewerkers, leerlingen en ouders en is het niet toegestuurd naar het bestuur of de gemeente. Het merendeel van de docenten onderschrijft het belang van een schoolgezondheidsplan en vindt ook dat dit plan bekend moet zijn bij medewerkers, ouders en leerlingen.

\section{Stap 5: Uitvoeren plan}

Op vier scholen wordt het schoolgezondheidsplan uitgevoerd. Ook worden op vrijwel alle scholen activiteiten uitgevoerd. Op de meeste scholen worden prioriteiten toegepast in het dagelijks werk en worden geplande activiteiten besproken in het teamoverleg. Het overgrote deel van de docenten vindt het belangrijk dat er preventieactiviteiten worden uitgevoerd en dat de preventieprioriteiten daadwerkelijk worden toegepast in het dagelijks werk. Aanvullend bleek uit de interviews dat het vaak lastig wordt gevonden om plannen ook daadwerkelijk gerealiseerd te krijgen binnen de school. Er worden preventieactiviteiten uitgevoerd, maar deze staan vaak niet beschreven in plannen. 
Stap 6: Evalueren en verankeren

Op vijf scholen wordt de uitvoering van het schoolgezondheidsplan geëvalueerd. Op drie scholen is er sprake van tussentijdse evaluatie. Het belang van evaluatie wordt door het overgrote merendeel van de docenten onderschreven.

"Ja, het lastige is, als je dat beleid niet zo nadrukkelijk geformuleerd hebt, is het natuurlijk ook lastig om dat te evalueren." Zorgcoördinator 2

Tabel 1: Implementatie van het schoolslag-stappenplan volgens managementleden en zorgcoördinatoren

\begin{tabular}{|c|c|c|c|c|c|}
\hline \multirow[t]{2}{*}{$\begin{array}{l}\text { Schoolslag- } \\
\text { stappenplan }\end{array}$} & \multirow[t]{2}{*}{ Vraagstelling (binnen de school ...) } & \multicolumn{3}{|c|}{$\begin{array}{l}\text { Participant niveau } \\
\underline{\mathrm{N}=\text { wisselend }}\end{array}$} & \multirow{2}{*}{$\begin{array}{l}\begin{array}{l}\text { School } \\
\text { niveau } \\
\mathrm{N}=18\end{array} \\
\mathrm{~N}\end{array}$} \\
\hline & & $\mathbf{N}$ & $\mathbf{N}$ & $\%$ & \\
\hline & & Totaal & Ja & Ja & $\mathrm{Ja}$ \\
\hline \multirow{3}{*}{$\begin{array}{l}\text { Stap } 1 \\
\text { Inventarisatie zorg- } \\
\text { behoefte en lopende } \\
\text { preventieactiviteiten }\end{array}$} & is er aandacht voor gezondheid en veiligheid & 98 & 72 & 73 & 15 \\
\hline & is een preventieteam aanwezig & 96 & 60 & 63 & 12 \\
\hline & is een overzicht van activiteiten aanwezig & 79 & 41 & 52 & 11 \\
\hline \multirow{5}{*}{$\begin{array}{l}\text { Stap } 2 \\
\text { Bepalen } \\
\text { van prioriteiten }\end{array}$} & worden prioriteiten voor preventie gesteld & 90 & 73 & 81 & 16 \\
\hline & Zijn prioriteiten gebaseerd op onderzoek & 69 & 54 & 78 & 13 \\
\hline & worden prioriteiten besproken in teamoverleg & 82 & 57 & 70 & 12 \\
\hline & worden prioriteiten besproken met ouders & 72 & 30 & 42 & 8 \\
\hline & worden prioriteiten besproken met leerlingen & 75 & 29 & 39 & 7 \\
\hline \multirow{7}{*}{$\begin{array}{l}\frac{\text { Stap 3 }}{\text { Kiezen }} \\
\text { van activiteiten }\end{array}$} & is een themawerkgroep aanwezig & 93 & 50 & 54 & 8 \\
\hline & worden activiteiten onderling afgestemd & 67 & 40 & 60 & 9 \\
\hline & wordt samengewerkt met de GGD & 92 & 90 & 98 & 17 \\
\hline & wordt samengewerkt met het welzijnswerk & 91 & 61 & 67 & 13 \\
\hline & $\begin{array}{l}\text { wordt samengewerkt met de geestelijke } \\
\text { gezondheidszorg }\end{array}$ & 88 & 57 & 65 & 12 \\
\hline & wordt samengewerkt met Bureau Halt & 84 & 53 & 63 & 10 \\
\hline & wordt samengewerkt met de verslavingspreventie & 89 & 38 & 43 & 7 \\
\hline
\end{tabular}


vervolg tabel 1

\begin{tabular}{|c|c|c|c|c|c|}
\hline \multirow[t]{2}{*}{$\begin{array}{l}\text { Schoolslag- } \\
\text { stappenplan }\end{array}$} & \multirow[t]{3}{*}{ Vraagstelling (binnen de school ...) } & \multicolumn{3}{|c|}{$\begin{array}{l}\text { Participant niveau } \\
\underline{\mathrm{N}=\text { wisselend }}\end{array}$} & \multirow{2}{*}{$\begin{array}{l}\begin{array}{l}\text { School } \\
\text { niveau } \\
N=18 \\
N\end{array} \\
\text { N }\end{array}$} \\
\hline & & $\mathbf{N}$ & $\mathbf{N}$ & $\%$ & \\
\hline & & Totaal & $\mathrm{Ja}$ & Ja & $\mathrm{Ja}$ \\
\hline \multirow{14}{*}{$\begin{array}{l}\text { Stap } 4 \\
\text { Opstellen school- } \\
\text { gezondheidsplan }\end{array}$} & is een schoolgezondheidsplan aanwezig & 79 & 14 & 18 & 5 \\
\hline & $\begin{array}{l}\text { - in het schoolgezondheidsplan worden behoefte } \\
\text { van zorg en gezondheid beschreven }\end{array}$ & 14 & 9 & 64 & 4 \\
\hline & $\begin{array}{l}\text { - in het schoolgezondheidsplan worden } \\
\text { onderzoeksresultaten beschreven }\end{array}$ & 14 & 6 & 43 & 3 \\
\hline & $\begin{array}{l}\text { - in het schoolgezondheidsplan worden } \\
\text { prioriteiten beschreven }\end{array}$ & 14 & 7 & 50 & 4 \\
\hline & $\begin{array}{l}\text { - in het schoolgezondheidsplan worden } \\
\text { strategieën en activiteiten beschreven }\end{array}$ & 14 & 8 & 57 & 4 \\
\hline & $\begin{array}{l}\text { - in het schoolgezondheidsplan worden } \\
\text { activiteiten opgenomen }\end{array}$ & 14 & 11 & 79 & 5 \\
\hline & $\begin{array}{l}\text { hebben medewerkers inspraak in het school- } \\
\text { gezondheidsplan }\end{array}$ & 96 & 23 & 24 & 6 \\
\hline & $\begin{array}{l}\text { hebben leerlingen inspraak in het schoolgezond- } \\
\text { heidsplan }\end{array}$ & 95 & 14 & $15^{*}$ & 4 \\
\hline & $\begin{array}{l}\text { hebben ouders inspraak in het schoolgezondheids- } \\
\text { plan }\end{array}$ & 94 & 14 & 15 & 4 \\
\hline & $\begin{array}{l}\text { is het schoolgezondheidsplan bekend bij } \\
\text { medewerkers }\end{array}$ & 96 & 12 & 13 & 1 \\
\hline & is het schoolgezondheidsplan bekend bij ouders & 96 & 5 & 5 & 1 \\
\hline & $\begin{array}{l}\text { is het schoolgezondheidsplan bekend bij } \\
\text { leerlingen }\end{array}$ & 95 & 6 & 6 & 1 \\
\hline & $\begin{array}{l}\text { is het schoolgezondheidsplan toegestuurd } \\
\text { aan het bestuur }\end{array}$ & 37 & 10 & 27 & 1 \\
\hline & $\begin{array}{l}\text { is het schoolgezondheidsplan toegestuurd aan } \\
\text { de gemeente }\end{array}$ & 34 & 1 & 3 & 0 \\
\hline \multirow{4}{*}{$\begin{array}{l}\text { Stap 5: } \\
\text { Uitvoeren plan }\end{array}$} & wordt het schoolgezondheidsplan uitgevoerd & 46 & 16 & 35 & 4 \\
\hline & worden activiteiten uitgevoerd & 95 & 90 & 95 & 17 \\
\hline & worden prioriteiten toegepast in het dagelijkse werk & 95 & 37 & 39 & 10 \\
\hline & $\begin{array}{l}\text { worden geplande activiteiten besproken in het } \\
\text { teamoverleg }\end{array}$ & 86 & 61 & 71 & 14 \\
\hline \multirow{3}{*}{$\begin{array}{l}\text { Stap } 6 \\
\text { Evalueren en } \\
\text { verankeren }\end{array}$} & wordt de uitvoering van het schoolgezondheidsplan & & & & \\
\hline & geëvalueerd & 44 & 17 & 39 & 5 \\
\hline & $\begin{array}{l}\text { wordt de kwaliteit van de uitvoering van het plan } \\
\text { bewaakt middels tussentijdse evaluatie }\end{array}$ & 42 & 9 & 21 & 3 \\
\hline
\end{tabular}

* Kruskal Wallis Test significant $(p<0,05)$ op groepsniveau. 
Tabel 2: Betrokkenheid van docenten en ervaren belang van aspecten van de werkwijze ( $N=397)$

\begin{tabular}{|c|c|c|}
\hline Docenten & Vraagstelling & $\begin{array}{l}\% \\
\text { ja }\end{array}$ \\
\hline \multirow[t]{6}{*}{ Betrokkenheid } & bent u geïnformeerd over de resultaten van de Limburgse jeugdmonitor & 5 \\
\hline & bent $u$ betrokken geweest bij het in kaart brengen van de huidige activiteiten & 3 \\
\hline & bent u betrokken geweest bij het stellen van prioriteiten & 2 \\
\hline & bent $\mathrm{u}$ betrokken geweest bij het opstellen van het schoolgezondheidsplan & 1 \\
\hline & heeft u het schoolgezondheidsplan van de school in uw bezit & 2 \\
\hline & gebruikt $u$ het schoolgezondheidsplan in de praktijk & 4 \\
\hline \multirow[t]{12}{*}{ Belang } & Hoe belangrijk is... & $\begin{array}{r}\% \\
\text { [zeer] } \\
\text { belangrijk }\end{array}$ \\
\hline & aandacht voor gezondheid & 96 \\
\hline & inspraak van medewerkers bij prioriteiten & 82 \\
\hline & inspraak van ouders bij prioriteiten & 50 \\
\hline & inspraak van leerlingen bij prioriteiten & 56 \\
\hline & het schoolgezondheidsplan & 81 \\
\hline & bekendheid van het schoolgezondheidsplan bij medewerkers & 88 \\
\hline & bekendheid van het schoolgezondheidsplan bij ouders & 81 \\
\hline & bekendheid van het schoolgezondheidsplan bij leerlingen & 81 \\
\hline & uitvoeren van activiteiten & 92 \\
\hline & het toepassen van prioriteiten in het dagelijks werk & 89 \\
\hline & de evaluatie van activiteiten & 86 \\
\hline
\end{tabular}

\section{Belemmerende en bevorderende factoren}

In de interviews kwam veelvuldig naar voren dat gezondheid nog vaak een achtergesteld thema is omdat er geen verplichtingen ten aanzien van gezondheidsbevordering opgenomen zijn in de kerndoelen. Toch voelen scholen zich verantwoordelijk voor de gezondheid van hun leerlingen. De schoolslag-werkwijze is gebaseerd op de "whole school approach". Hierin staat naast gezonde leerlingen ook de gezondheid van docenten, onderwijsondersteunend personeel en de omgeving centraal. In dit interview is enkel ingegaan op de gezondheid van de leerlingen. Door diverse geïnterviewden werd daarbij de kanttekening geplaatst dat de doelen realistisch moeten zijn. Diverse keren werd gezegd dat er geen behoefte is aan veel papier, maar aan daadwerkelijke actie. 
"Ik denk dat je heel reëel moet blijven. De werkdruk in het onderwijs is heel erg hoog en

De meeste scholen hebben geen uren voor gezondheidsbevordering begroot. Gezondheidsbevordering komt als extra taak bovenop de bestaande werkuren van een zorgcoördinator, mentor of docent. Binnen de huidige werkdruk wordt dit als erg zwaar ervaren. Gezondheidsbevordering werd genoemd als (additionele) taak van de school, maar deze verantwoordelijkheid wordt niet omgezet in formatie-uren. In meerdere interviews werd ingebracht dat er ondanks de beperkte tijd "veel tussen de bedrijven door" gebeurt, maar dat door het ontbreken van een gerichte structuur scholen geen tijd vrijmaken voor structurering en borging. Meermalen werd naar voren gebracht dat door het uitblijven van een duidelijke visie op gezondheid vanuit het management, gezondheidsbevordering een extra activiteit blijft. De daadwerkelijke betrokkenheid van het management bij schoolgezondheidsbeleid wordt ervaren als minimaal. Door diverse participanten werd benadrukt dat schoolgezondheidsbeleid pas zal slagen wanneer het in de taakbelasting van het onderwijs wordt meegenomen. Een duidelijke taakomschrijving met vastgestelde uren wordt vooralsnog gemist.

Door diverse participanten werd ook het ontbreken van een duidelijk communicatieplan als een belemmerende factor ervaren. Hierdoor is er geen brede bekendheid van schoolgezondheidsbeleid binnen de school en heeft het nog geen vaste plek gekregen binnen het huidige onderwijssysteem. Er is nog nauwelijks structureel contact tussen de contactpersoon voor preventie binnen de school en het management. Hierdoor is de betrokkenheid van het management nauwelijks voelbaar.

Tenslotte gaven enkele participanten aan dat wanneer door de schoolslag-adviseur te strak wordt vastgehouden aan de volgorde van het schoolslag-stappenplan, de bevlogenheid en betrokkenheid van het team kunnen afnemen. Er moet ruimte zijn om de volgorde aan te passen aan het proces binnen de school. De doelstellingen van de werkwijze moeten aansluiten bij de visie van de school. Als dat het geval is, zal het team zijn verantwoordelijkheid nemen binnen de huidige kaders om de doelen te realiseren.

“Mensen moeten toch ook allemaal een bepaalde vrijheid, eigen keuze hebben. Als je alles gaat voorkauwen dan voel je je, als docent, volgens mij in zo'n keurslijf geperst van dit moet er nog in, dat moet er nog in en die mentor lessen zijn vol. Alles is zo gestructu- 


\section{Discussie en conclusies}

Met dit onderzoek werd beoogd inzicht te krijgen in de huidige mate van implementatie van de schoolslag-werkwijze. Het blijkt dat de eerste stappen van het stappenplan breed worden ingezet. Naarmate de stappen meer gericht zijn op verankering in de vorm van het schrijven, uitvoeren, evalueren en, waar nodig, aanpassen van de plannen zodat ze opgenomen kunnen worden in het beleid van de school, neemt de mate van toepassing echter af. Van de continuïteit waar de schoolslag-werkwijze naar streeft, is op dit moment nog geen sprake. Er worden maar zeer beperkt schoolgezondheidsplannen opgesteld. Evaluatie en opname in het schoolbeleid ontbreken. Ook participatie van de doelgroep wordt nog zeer beperkt geïmplementeerd. Inspraak van leerlingen en ouders wordt ook niet door alle docenten belangrijk gevonden. De daadwerkelijke betrokkenheid van de docenten is zeer beperkt. Al met al kan gezegd worden dat er een goede start is gemaakt, maar dat de implementatie van de werkwijze nog verre van optimaal is.

Op basis van de literatuur weten we dat de invoering van een innovatie veel tijd nodig heeft.(Rogers 1995; Marx and Wooley 1998; Shediac and Bone 1998; Fleuren, Wieferink en anderen 2004) Naast het ontwikkelen van een goed doordachte werkwijze gebaseerd op de theorie, zijn veel randvoorwaarden te noemen die de invoering ervan positief of negatief kunnen beïnvloeden. (Rogers 1995; Marx and Wooley 1998; Shediac and Bone 1998; Fleuren, Wieferink en anderen 2004) Met behulp van dit onderzoek hebben we meer inzicht gekregen in de specifieke factoren die de implementatie van de schoolslag-werkwijze beïnvloeden. De genoemde belemmerende factoren zijn met name gerelateerd aan de implementerende organisatie (de school), de ondersteunende organisatie (GGD of één van de partners) en de maatschappelijke context. Een aantal hiervan zijn niet beïnvloedbaar vanuit de schoolslag-werkwijze zoals de (ervaren) hoge werkdruk in het onderwijs. Wat betreft het ontbreken van een verplichting om expliciet aan gezondheidsbevordering te werken en daaraan gerelateerd het ontbreken van een taakbeschrijving en formatie-uren voor gezondheidsbevordering, lijken er echter veranderingen gaande te zijn. Door ondertekening van het convenant "scholen voor primair en voortgezet onderwijs en sponsoring" onderschrijven het ministerie van OC\&W en de landelijke onderwijskoepels de maatschappelijke verantwoordelijkheid van het onderwijs op het gebied van een gezonde leefstijl. In het convenant wordt gesteld dat scholen verplicht zijn in het curriculum aandacht te besteden aan gezonde leefstijl en beweging.(Staatscourant 2009) Dit onderschrijft de steeds terugkerende discussie over de rol van het onderwijs bij de opvoeding van jongeren. De verplichting is echter nog niet opgenomen in de kwaliteitsagenda voor het voortgezet onderwijs(VO-raad and Ministerie van OC\&W 2008) en wordt nog niet getoetst in de beoordeling van kwaliteit door de onderwijsinspectie. Beide organen zijn leidend voor de prioriteitstelling in het onderwijs. Zolang gezondheidsbevordering hierin geen eigen plek krijgt, zal het niet automatisch op de prioriteitenlijst van de afzonderlijke scholen worden geplaatst.(SLO 2007) 
In verschillende regio's in Nederland hebben GGD'en samen met scholen zelf het initiatief genomen om een taakomschrijving voor gezondheidsbevordering binnen het onderwijs op te stellen en concrete afspraken te maken over investering van uren door de school. Deze afspraken kunnen de betrokkenheid binnen de school vergroten en de verantwoordelijkheid van de school voor de gezondheid van hun leerlingen verder uitbouwen. Om daadwerkelijk een verandering binnen het totale onderwijs te kunnen realiseren, is het aan te bevelen gezondheid op te nemen in de kwaliteitsagenda van het voortgezet onderwijs. Mogelijk kan de kennis over de invloed van gezondheid op de prestaties van het onderwijs binnen deze lobby als hulpmiddel dienen.

In het onderzoek worden belangrijke punten voor verbetering genoemd: de schoolslag-werkwijze lijkt te theoretisch, de doelen zouden beter moeten aansluiten bij de mogelijkheden en onmogelijkheden in het onderwijs, er wordt door de schoolslag-adviseurs teveel vastgehouden aan de volgorde van het schoolslag-stappenplan, het management is onvoldoende betrokken en een communicatieplan ontbreekt. Deze verbeterpunten zouden opgenomen kunnen worden in de werkwijze door te kiezen voor een modulair systeem. Een belangrijk voordeel hiervan is dat scholen en hun ondersteunende organisaties de werkwijze kunnen aanpassen aan hun wensen en mogelijkheden. De vraag is echter of met elke module, los van de andere modules gestart kan worden. Naar verwachting zullen de stappen gericht op het creëren van randvoorwaarden voor de invoering van de werkwijze eerst doorlopen moeten worden, of op zijn minst parallel aan de gewenste startmodule. RIVM-Centrum Gezond Leven werkt samen met de landelijke gezondheidsbevorderende instituten en een aantal GGD'en aan een Gezonde School handleiding voor ondersteuners. Mede op basis van de aanbevelingen uit dit onderzoek is hierbij gekozen voor een modulair systeem waarin aangeraden wordt de eerste module over oriënteren en organiseren als eerste door te lopen. Met deze inzichten kan de schoolslag-werkwijze, en de daarvan afgeleide Gezonde School Methode, en met name de rol van de schoolslag-adviseur cg Gezonde School adviseur worden verbeterd.

Een sterk punt van dit onderzoek was de combinatie van zowel kwantitatief als kwalitatief onderzoek en het conceptueel kader als leidraad voor de interviews. Hierdoor kon de bestaande situatie systematisch worden geïnventariseerd, waren de onderzoekers alert op een breed scala aan mogelijk beïnvloedende factoren maar was er ook alle ruimte voor nieuwe inzichten.

Een kanttekening die bij de studie geplaatst moet worden, is dat niet alle scholen voor voortgezet onderwijs in de regio -en daarbinnen niet alle medewerkers- bereid waren deel te nemen aan het onderzoek. Niet-deelnemers zouden een andere visie op de schoolslag-werkwijze kunnen hebben waardoor ze niet hebben deelgenomen. Dit vraagt om een nadere verkenning. Niettemin heeft het merendeel van de scholen meegewerkt. Op basis van de reguliere contacten van GGD Zuid Limburg met de non-respons scholen lijken de huidige onderzoeksresultaten een 
representatief beeld te geven van de huidige positie van schoolgezondheidsbeleid binnen het voortgezet onderwijs in Zuid-Limburg. Op basis van uitwisselingen met coördinatoren Gezonde School uit andere regio's wordt daarnaast verondersteld dat de resultaten uit voorliggende studie ook breder in Nederland toepasbaar zijn.

Geconcludeerd kan worden dat er tussen gezondheidsbevordering en het onderwijs vooralsnog eerder sprake is van een verstandshuwelijk dan van echte liefde. Liefde staat voor onvoorwaardelijk en belangeloos. Aandacht voor gezondheid gaat nu nog veelal gepaard met een grote "Ja, maar". Toch is dit geen reden voor scepsis. Goede gezondheid en goed onderwijs hangen tenslotte sterk samen. Het invoeren van een innovatie kost tijd, net zoals liefde soms moet groeien. Waar in 2002 het begrip "schoolgezondheidsbeleid" nog onbekend was voor scholen, zijn scholen nu de samenwerking met een schoolslag-adviseur aangegaan, zijn ze bereid na te denken over mogelijkheden om schoolgezondheidsbeleid binnen hun school op de agenda te krijgen en, waar mogelijk, de verantwoordelijkheid te nemen om gezondheidsdoelen te realiseren. Wanneer bij de toepassing van de schoolslag-werkwijze meer rekening wordt gehouden met de mogelijkheden en onmogelijkheden van het onderwijs en het realiseren van betrokkenheid en verbeteringen in de toepassing van de werkwijze worden doorgevoerd, dan kan de werkwijze een goede vorm van begeleiding voor het onderwijs zijn. Wat dit betekent voor de competenties van de professionals die scholen begeleiden op het terrein van schoolgezondheidsbeleid, vraagt nader onderzoek.

\section{Noten}

a In 2002-2006 is de schoolslag-werkwijze in Zuidelijk Zuid-Limburg ontwikkeld door GGD Zuid Limburg in samenwerking met Universiteit Maastricht, Het Nationaal Instituut Gezondheidsbevordering en Ziektepreventie (NIGZ), en de betrokken preventiepartners (geestelijke gezondheidszorg (Riagg), welzijnswerk (Trajekt), verslavingspreventie (Mondriaan Zorggroepl en Bureau Jeugdzorg).

b De Jeugdmonitor is een vragenlijst over leefstijl voor jongeren van klas 2 en 4 van het voortgezet onderwijs. De vragenlijst wordt om de vier jaar afgenomen. De resultaten worden op schoolniveau teruggekoppeld en vormen een hulpmiddel voor het stellen van prioriteiten. 


\section{Hoofdstuk 4:}

\section{Professional assistance in implementing school health policies}

\section{Gepubliceerd als:}

Boot, N., Van Assema, P., Hesdahl, B. en De Vries, N.

Professional assistance in implementing school heatlh policies. Health Education 2010 110:294-308. 


\section{Abstract}

The purpose of this study was to evaluate the role of a school health promotion (SHP) advisor in the implementation of the six steps of the Dutch 'Schoolbeat' approach, aimed at establishing health promotion policies and activities in secondary schools.

Eighty school board members and 18 prevention coordinators of 18 schools in the Southern Limburg region in the Netherlands completed a written questionnaire on the implementation of the six steps of the Schoolbeat approach, and on their satisfaction with the practical assistance offered by the SHP advisor in implementing the steps, as well as the advisor's organizational competencies.

Only one school had implemented the Schoolbeat approach completely and as intended. Schools were generally satisfied with the practical assistance in the process of implementing the Schoolbeat steps and with the organizational competencies of the SHP advisor. Schools which had partly implemented the Schoolbeat steps were more satisfied with the SHP advisor's practical assistance than schools who had not done so at all.

This study showed that the SHP advisor can make a positive contribution to health promotion in schools. Since this role demands new skills, the competencies of health promotion professionals must be further developed.

Structural school health promotion programs and policies are becoming increasingly important in many countries, and not enough is known about the role of health promotion agencies in structuring school health promotion. This paper describes the positive impact of the SHP advisor. 


\section{Introduction}

In many countries, school-based health promotion programs and policies are increasingly considered to be an important opportunity to reduce health problems in youngsters (Allensworth 1993; St.Leger and Nutbeam 1999; Aggleton, Rivers en anderen 2000; Inchley, Currie en anderen 2000; Moon 2000; Parsons and Stears 2002; St.Leger 2004; St.Leger 2005; Gabhainn, Sixsmith en anderen 2007). In the Netherlands schools are autonomous regarding their health promotion policy. There is no legal obligation for implementing school health promotion programs or policies. As a consequence, regional public health services stimulate and support schools in implementing health promotion programs and policies (De Jongh, Blokdijk en anderen 2009), mostly by suggesting, providing, and/or delivering specific interventions. However, the potential role of health promotion agencies in structuring school health promotion is not yet fully defined (Stewart-Brown 2006; Davis and Cooke 2007).

In the Southern Limburg region of the Netherlands, a project was started in 2002 to address structural health promotion programs and policy in secondary schools, called the Schoolbeat approach. The main aim of this program was to reduce adolescents' health risk behavior by guiding schools in establishing planned and structural school health promotion programs and policies (Leurs and Jansen 2002; Leurs, Jansen en anderen 2002; Leurs, Jansen en anderen 2004; Leurs, Jansen en anderen 2005; Leurs, Bessems en anderen 2007).

Before the start of the Schoolbeat approach many organizations for health promotion would approach schools with their prevention programs. Due to the resulting lack of coherence and lack of collaboration, schools were overloaded with offers and found it difficult to choose. As a consequence, attention for health promotion in schools was marginal and ad hoc. This situation changed with the start of the Schoolbeat approach, which was a collaboration between all regional partner organizations specializing in health, welfare, safety, student care and youth care, coordinated by the Schoolbeat coordinator. This Schoolbeat coordinator coordinates the efforts of the represented regional partners, implementing health promotion in schools. Their shared interest was the reason for collaboration, they were partners committed to the common goals over and above their own corporate interests.

To implement collaborative efforts a six-step approach was developed. The first step was to determine the health needs of the school, based on available epidemiological data regarding the students, as well as data on their academic performance. Step two involved setting health promotion priorities based on the information gathered in the first step. During this step the opinion of the school team, parents and students play an important role. In step three, important and modifiable determinants of priority problems were identified to select possible activities focused 
on students, staff, school, school policy and the community. In step four, a school health plan was written on the basis of all the previous steps. Step five involves the implementation of the school health plan and activities and step six was a school-based evaluation.

Schools that apply the Schoolbeat approach were asked to appoint a prevention coordinator, a person responsible for all activities related to structural the school health promotion programs and policies. This position was often allocated to the school care worker, located in support staff, who was responsible for all health care activities at the school. This ensured a close link between health care for individual students and health promotion for the school population as a whole. The prevention coordinator chaired a school prevention team, consisting of representatives of teachers, students and parents.

A second important actor in the Schoolbeat approach was the school health promotion advisor (SHP advisor). This person represents all participating regional partner organizations specializing in health, welfare, safety, student care and youth care, with their expertise. The SHP advisor provided the schools with a single contact person who maintained the links between the school and all health promotion partners. As such, the SHP advisor was the link between schools and the supporting organizations. The decision to appoint one single contact person for all health promoting agencies in the collaboration implied a transition from a campaign-driven approach to an approach driven by the schools' demands. It was no longer the programs offered by the various health promotion agencies that determined the interventions, but the demand by the schools. The Schoolbeat coordinator was responsible for coaching of the SHP-advisors.

The main task of the SHP advisor was to support the school in implementing the six steps of the Schoolbeat approach. The SHP-advisors contacted the prevention coordinator every two months. During this contact the current state of health promotion in the school was discussed and the next steps in the Schoolbeat approach prepared. To standardize the approach of the different SHP advisors, a profile was used that described the main competencies of the SHP advisor, namely: knowledge of health promotion activities; social skills, a feeling for mutual relationships; an analytical attitude; the ability to plan tasks in a structured way, and well motivated. Similarly advisor's tasks were also specified, namely: report research results; assist the school in the evaluation of current health promotion activities; stimulate and advise in determining health needs and setting priorities; be a matchmaker between the school and regional health promotion organizations; and assist the school in writing, implementing and evaluating the school health plan. The formal hierarchical position of the SHP advisors remained within the own organization. All SHP advisors worked as health promotion professional with schools before being appointed. 
The practical operationalization of the Schoolbeat approach was the responsibility of the Schoolbeat coordinator. The Schoolbeat coordinator had regular contact with the SHP advisor and coached them by implementing the Schoolbeat approach in the schools they assisted. Annually the current state of implementation of the Schoolbeat-approach and the collaboration between the SHP advisor and the school is evaluated by the Schoolbeat coordinator and the SHP advisors. Also there is regular contact between the Schoolbeat coordinator and the managers of the prevention organizations. The functioning of the SHP advisors is one of the topics.

The Schoolbeat approach has now been in use for eight years. Twelve health promotion professionals are working as SHP advisors, and all 25 secondary schools in Southern Limburg have a SHP advisor. The assistance offered by the SHP advisors generally has two main aspects. The first is practical assistance to help schools implement the Schoolbeat steps, using the advisor's knowledge of the Schoolbeat approach and school health promotion in general to support the prevention (description see table 2). The second is the organizational competencies of the SHP advisor, related to building relationships of trust in the coalition of schools and prevention organizations that give up some autonomy (description see table 2).

The DISC model (Leurs, Schaalma en anderen 2005; Leurs, Mur-Veeman en anderen 2008) describes factors affecting the evolution of collaboration between the stakeholders in the Schoolbeat approach. The main factors are interactions between the project management, the collaborating partners, the project organization and aspects of the context within the organization of the stakeholders. Mutual trust is one of the factors this model includes as crucial for successful collaboration, influencing the motivation for collaborative support.

This article aims to evaluate the role of the SHP advisor in the Schoolbeat approach. The following research questions are addressed:

1. To what extent are the six steps of the Schoolbeat approach being implemented in secondary schools in Southern Limburg (the Netherlands)?

2. Are schools satisfied with the practical assistance and the organizational competencies of their SHP advisor?

3. Is there a relationship between the level of satisfaction with the practical assistance and the organizational competencies of the SHP advisor and the implementation of the Schoolbeat approach? 


\section{Methods}

The study took place in February - June 2008 among members of school boards and prevention coordinators of secondary schools in the Southern Limburg region.

\section{Respondents}

All 25 secondary schools in the region were invited to participate. All school boards were first sent a letter to inform them about the planned research project and the benefits to their schools. The letter also announced a telephone call, a week later, in which the goal of the research and the benefits to the school were again explained and questions were answered. After a school had agreed to participate, practical arrangements were made for the distribution of the questionnaire. Nineteen schools agreed to participate; 215 questionnaires were sent to all 196 school board members and 19 prevention coordinators of the participating schools.

\section{Questionnaire}

The questionnaire consisted of 39 questions, 20 of which addressed the implementation of the six steps of the Schoolbeat approach (see column 2 in Table 1). Three questions assessed step 1 , determining the health needs of the school. Three questions focused on step 2 , setting health promotion priorities. Two questions addressed step 3, assessing the important and modifiable determinants. Six questions assessed step 4, designing the school health plan. Four questions related to step 5, implementation. Two questions addressed step 6, school-based evaluation. Example questions were "At our school, a school health plan has been implemented" and "At our school, priorities for health promotion have been set". The answer options for these questions were yes, no, partly, not applicable.

Nine questions were asked about satisfaction with the practical assistance offered by the SHP advisor (Cronbach's alpha= .896), for example "Are you satisfied with the assistance offered to you in implementing the school health plan?" and "Are you satisfied with the assistance offered to you in organizing participation of team members in setting priorities?". The answer options were on a five-point scale: very dissatisfied, dissatisfied, neutral, satisfied, very satisfied). Ten questions were asked about the satisfaction with the organizational competencies of the SHP advisor (Cronbach's alpha= .883), for example "Does your SHP advisor have a relationship of trust with the school?" And "Is your SHP advisor competent in terms of his/her tasks?" The answer options were no, to some extent, yes.

The questionnaire was pretested with two prevention coordinators, after which the wording of the questionnaire was somewhat adapted. For instance, 'health promotion' was replaced by 'prevention of unhealthy and unsafe behavior'. 


\section{Analysis}

The data were analyzed using SPSS 17.0. Analyses were made both at respondent level and school level. At the respondent level, only school board members were selected. The data of the prevention coordinators were used for the school-level analysis. These coordinators were assumed to know most about the current situation in their school regarding the implementation of the Schoolbeat approach.

In assessing the extent of implementation of Schoolbeat, a step was considered to have been fully completed if all questions regarding that step were answered in the affirmative.

Mean total scores of the two satisfaction scales were computed. In addition to descriptive statistics, t-tests were used to compare mean satisfaction scores of schools that had implemented specific activities of the Schoolbeat approach with those of schools that had not.

\section{Results}

Sample

A total of 98 respondents from 18 schools returned the questionnaire. The sample consisted of 80 school board members (response $41 \%$ ) and 18 prevention coordinators (response $95 \%$ ). One school that had agreed to participate dropped out due to lack of time.

Implementation of the Schoolbeat approach (see tabel 1 on page 108)

\section{Respondent level analysis}

Table 1 shows that the items relating to step 1 (determining health needs), step 2 (setting priorities), and step 3 (identifying determinants), of the Schoolbeat approach were more often answered affirmatively than those relating to steps 4 (designing), 5 (implementation) and 6 (evaluating the health plan). However, most respondents (73 out of 98) reported that health promotion activities had been carried out, which is part of step 5 (implementation).

Whereas about a quarter of the respondents reported to have fully completed steps 1, 2 and 3 , the number of respondents who reported to have fully implemented the various steps decreased sharply for the later steps. None of the respondents reported that the Schoolbeat approach had been fully implemented as intended, from step 1 (determining health needs) to step 6 (school based evaluation). 
Table 1: Implementation of the Schoolbeat approach

\begin{tabular}{|c|c|c|c|}
\hline \multirow[t]{2}{*}{ Schoolbeat approach } & Statements for each step of the Schoolbeat approach & $\begin{array}{r}\text { Respondent level } \\
\qquad(\mathrm{N}=80)\end{array}$ & $\begin{array}{r}\text { School level } \\
(\mathrm{N}=18)\end{array}$ \\
\hline & (At our school ...) & & \\
\hline \multirow{3}{*}{$\begin{array}{l}\text { Step 1: } \\
\text { Determining the } \\
\text { health needs of the } \\
\text { school }\end{array}$} & attention is being devoted to health and safety & 57 & 15 \\
\hline & there is a prevention team in place & 48 & 12 \\
\hline & there is a framework for prevention activities & 30 & 11 \\
\hline \multicolumn{2}{|l|}{ - Step 1 completed } & 20 & 7 \\
\hline \multirow{3}{*}{$\begin{array}{l}\text { Step 2: } \\
\text { Setting health } \\
\text { promotion priorities }\end{array}$} & priorities for health promotion have been set & 57 & 16 \\
\hline & priorities are based on research & 41 & 13 \\
\hline & priorities have been discussed at team meetings & 45 & 12 \\
\hline \multirow{2}{*}{\multicolumn{2}{|c|}{$\begin{array}{l}\text { - Step } 2 \text { completed } \\
\text { - Step } 1+2 \text { completed }\end{array}$}} & 27 & 9 \\
\hline & & 12 & 4 \\
\hline \multirow{2}{*}{$\begin{array}{l}\text { Step 3: Identifying im- } \\
\text { portant and modifiable } \\
\text { determinants }\end{array}$} & there is a working group to examine the priorities & 42 & 8 \\
\hline & activities are coordinated within the team & 32 & 8 \\
\hline \multirow{2}{*}{\multicolumn{2}{|c|}{$\begin{array}{l}\text { - Step } 3 \text { completed } \\
\text { - Step 1+2+3 completed }\end{array}$}} & 19 & 4 \\
\hline & & 6 & 2 \\
\hline \multirow{6}{*}{$\begin{array}{l}\text { Step 4: } \\
\text { Designing the school } \\
\text { health plan }\end{array}$} & there is a school health plan & 9 & 5 \\
\hline & health needs have been described & 7 & 7 \\
\hline & research results have been described & 5 & 5 \\
\hline & priorities have been described & 6 & 7 \\
\hline & strategies have been described & 7 & 7 \\
\hline & activities have been described & 14 & 7 \\
\hline \multirow{2}{*}{\multicolumn{2}{|c|}{$\begin{array}{l}\text { - Step } 4 \text { completed } \\
\text { - Step } 1+2+3+4 \text { completed }\end{array}$}} & 2 & 3 \\
\hline & & 0 & 1 \\
\hline \multirow{4}{*}{$\begin{array}{l}\text { Step 5: } \\
\text { Implementation }\end{array}$} & a school health plan is being implemented & 12 & 4 \\
\hline & activities are being implemented & 73 & 17 \\
\hline & priorities are being incorporated in routine practice & 27 & 10 \\
\hline & planned activities are being discussed at team meetings & 47 & 14 \\
\hline \multirow{2}{*}{\multicolumn{2}{|c|}{$\begin{array}{l}\text { - Step } 5 \text { completed } \\
\text { - Step } 1+2+3+4+5 \text { completed }\end{array}$}} & 7 & 1 \\
\hline & & 0 & 1 \\
\hline \multirow[t]{2}{*}{$\begin{array}{l}\text { Step 6: School-based } \\
\text { evaluation }\end{array}$} & $\begin{array}{l}\text { the implementation of the school health plan is being } \\
\text { evaluated }\end{array}$ & 12 & 5 \\
\hline & $\begin{array}{l}\text { the quality of the implementation of the school health } \\
\text { plan is being evaluated }\end{array}$ & 6 & 3 \\
\hline \multicolumn{2}{|l|}{ - Step 6 completed } & 5 & 1 \\
\hline \multicolumn{2}{|c|}{ - Step $1+2+3+4+5+6$ completed } & 0 & 0 \\
\hline
\end{tabular}




\section{School level analysis}

The data at school level show similar results. The questions relating to steps 1 (determining health needs), 2 (setting priorities) and 5 (implementation) were answered affirmatively by more than half of the schools, with one exception: implementation of the school health plan in step 5 was reported by four schools only.

Earlier steps in the approach were completed by more schools. The number of schools that following step 1 to step 6 in the intended order decreased for step 4,5 and 6. As with the individual respondents, none of the prevention coordinators reported that the school fully implemented the Schoolbeat approach as originally intended. However, one school coordinator reported that they had completed the Schoolbeat approach up to step 5, implementation.

Satisfaction with the SHP advisor (see tabel 2 on page 110)

\section{Respondent level analysis}

Only some respondents filled out the questions of the scales satisfaction with practical assistance and with the organizational competencies. The responses to the practical assistance questions were rather favorable, with a mean total scale score of 0.65 (range -2 to 2), while the responses to the organizational competencies questions were highly favorable, with a mean total scale score of 1.81 (range 0 to 2). The respondents were least satisfied with the assistance offered in the school's attempts to get the school team, students, and parents to participate in setting priorities, with the assistance offered in evaluating the school health plan, and with the coordinating role of the SHP advisor.

\section{School level analysis}

The data at school level showed similar results. The prevention coordinators were least satisfied with the coordinating task of the SHP advisor in designing the school health plan.

Relationship between satisfaction with the SHP advisor and implementation of the Schoolbeat approach

Due to the very small amount of data from the questions relating to practical assistance and the organizational competencies of the SHP advisor at respondent level, the data were only analyzed at school level. 
Table 2: Satisfaction with practical assistance in implementing the steps of the Schoolbeat approach (PA) and with the organizational competencies $(0 \mathrm{C})$ of the SHP advisor

\begin{tabular}{|c|c|c|c|c|c|c|c|c|}
\hline \multirow{2}{*}{$\begin{array}{l}\text { Question } \\
\text { The schoole: } \\
\text { the assistance by... } \\
\text { (range }-2 \text { [very unsatisfied] } \\
\text { to } 2 \text { [very satisfied]] }\end{array}$} & \multicolumn{4}{|c|}{ Respondent level } & \multicolumn{4}{|c|}{ School level } \\
\hline & $\begin{array}{r}\mathbf{N} \\
\text { Total }\end{array}$ & $\begin{array}{r}\mathrm{N} \\
\text { [very) } \\
\text { satisfied }\end{array}$ & Mean & SD & $\begin{array}{r}\mathbf{N} \\
\text { Total }\end{array}$ & $\begin{array}{r}\mathrm{N} \\
\text { [very] } \\
\text { satisfied }\end{array}$ & Mean & SD \\
\hline $\begin{array}{l}\text { designing the school } \\
\text { health plan }\end{array}$ & 15 & 10 & 0.73 & 0.96 & 14 & 13 & 1.14 & 0.77 \\
\hline using research results & 15 & 12 & 0.93 & 0.59 & 14 & 11 & 1.14 & 0.77 \\
\hline identifying current activities & 19 & 16 & 1.00 & 0.75 & 14 & 12 & 1.21 & 0.70 \\
\hline $\begin{array}{l}\text { organizing participation of } \\
\text { parents in setting priorities }\end{array}$ & 14 & 4 & 0.21 & 0.58 & 13 & 7 & 0.46 & 0.66 \\
\hline $\begin{array}{l}\text { organizing participation of } \\
\text { students in setting priorities }\end{array}$ & 12 & 2 & 0.08 & 0.79 & 14 & 3 & 0.00 & 0.78 \\
\hline $\begin{array}{l}\text { organizing participation of team } \\
\text { members in setting priorities }\end{array}$ & 11 & 3 & 0.09 & 0.94 & 14 & 8 & 0.57 & 0.76 \\
\hline drawing up activity plan & 14 & 9 & 0.64 & 0.75 & 14 & 11 & 1.07 & 0.92 \\
\hline implementing school health plan & 12 & 4 & 0.25 & 0.62 & 12 & 7 & 0.67 & 0.89 \\
\hline evaluating school health plan & 11 & 2 & 0.09 & 0.54 & 12 & 7 & 0.67 & 0,89 \\
\hline Mean total PA scale score: & 19 & & 0.65 & 0.52 & 15 & & 0.64 & 0.95 \\
\hline $\begin{array}{l}\text { OC scale: } \\
\text { Our SHP advisor...... } \\
\text { (Range } 0 \text { [no], 1 [partly], } \\
\text { 2[yes]) }\end{array}$ & $\begin{array}{r}\mathbf{N} \\
\text { Total }\end{array}$ & $\begin{array}{r}\mathrm{N} \\
\text { yes }\end{array}$ & Mean & SD & $\begin{array}{r}\mathbf{N} \\
\text { Total }\end{array}$ & $\begin{array}{r}\mathrm{N} \\
\text { yes }\end{array}$ & Mean & SD \\
\hline $\begin{array}{l}\text { allocates a central role to the } \\
\text { school }\end{array}$ & 18 & 15 & 1.83 & 0.38 & 14 & 12 & 1.86 & 0.36 \\
\hline is competent in her/his tasks & 19 & 18 & 1.95 & 0.23 & 14 & 13 & 1.93 & 0.27 \\
\hline $\begin{array}{l}\text { has enough knowledge about } \\
\text { the Schoolbeat approach }\end{array}$ & 19 & 17 & 1.89 & 0.32 & 14 & 13 & 1.93 & 0.27 \\
\hline complies with agreements & 19 & 18 & 1.95 & 0.23 & 14 & 13 & 1.86 & 0.54 \\
\hline $\begin{array}{l}\text { has a relationship of trust with } \\
\text { the school }\end{array}$ & 19 & 17 & 1.89 & 0.32 & 14 & 12 & 1.86 & 0.36 \\
\hline $\begin{array}{l}\text { has enough experience of } \\
\text { health and safety }\end{array}$ & 19 & 18 & 1.95 & 0.23 & 14 & 13 & 1.93 & 0.27 \\
\hline $\begin{array}{l}\text { can advise the school about } \\
\text { health and safety activities }\end{array}$ & 18 & 16 & 1.89 & 0.32 & 14 & 12 & 1.86 & 0.36 \\
\hline $\begin{array}{l}\text { fulfills her/his coordination } \\
\text { task by designing the school } \\
\text { health plan }\end{array}$ & 18 & 9 & 1.44 & 0.62 & 13 & 8 & 1.62 & 0.51 \\
\hline functions as a central access point & 18 & 9 & 1.50 & 0.51 & 14 & 11 & 1.71 & 0.61 \\
\hline $\begin{array}{l}\text { plays a coordinating role in } \\
\text { prevention and safety }\end{array}$ & 18 & 9 & 1.44 & 0.62 & 14 & 12 & 1.86 & 0.36 \\
\hline Mean total scale OC score: & 19 & & 1.81 & 2.28 & 14 & & 1.84 & 0.29 \\
\hline
\end{tabular}


Table 3: Scores on satisfaction with the practical assistance (PA) and the organizational competencies (OC) of the SHP advisor of schools that did complete a particular step of the Schoolbeat approach and schools that did not complete that step

\begin{tabular}{|c|c|c|c|c|c|}
\hline \multirow[t]{2}{*}{$\begin{array}{l}\text { Statements for each step of the Schoolbeat approach } \\
\text { (At our school ...) }\end{array}$} & \multirow[b]{2}{*}{ Groups } & \multicolumn{2}{|c|}{$\begin{array}{r}\text { Satisfaction with } \\
\text { PA } \\
\text { range }-2 \text { to } 2\end{array}$} & \multicolumn{2}{|c|}{$\begin{array}{r}\text { Satisfaction with } \\
\mathrm{OC} \\
\text { range } 0 \text { to } 2\end{array}$} \\
\hline & & $\mathbf{N}$ & Mean & $\mathbf{N}$ & Mean \\
\hline \multicolumn{6}{|l|}{ Step 1 Determining the health needs of the school } \\
\hline \multirow[t]{2}{*}{ attention is being devoted to health and safety } & Yes completed & 12 & $0.98^{* *}$ & 12 & $1.91 * *$ \\
\hline & No completed & 3 & -1.30 & 2 & 1.40 \\
\hline \multirow[t]{2}{*}{ there is a prevention team in place } & Yes completed & 11 & 0.85 & 11 & 1.82 \\
\hline & No completed & 4 & 0.08 & 3 & 1.93 \\
\hline \multirow[t]{2}{*}{ there is a framework for prevention activities } & Yes completed & 11 & 0.78 & 11 & 1.82 \\
\hline & No completed & 3 & 1.01 & 3 & 1.90 \\
\hline \multirow[t]{2}{*}{ Step 1 Determining the health needs of the school } & Yes completed & 7 & 1.00 & 7 & 1.91 \\
\hline & No completed & 8 & 0.33 & 7 & 1.77 \\
\hline \multicolumn{6}{|l|}{ Step 2 Setting health promotion priorities } \\
\hline \multirow[t]{2}{*}{ priorities for health promotion have been set } & Yes completed & 13 & 0.84 & 13 & 1.83 \\
\hline & No completed & 1 & 0.67 & 1 & 1.90 \\
\hline \multirow[t]{2}{*}{ priorities are based on research } & Yes completed & 12 & $0.88 \mathrm{a}$ & 12 & $1.84 \mathrm{a}$ \\
\hline & No completed & 0 & a & 0 & a \\
\hline \multirow[t]{2}{*}{ priorities have been discussed at team meetings } & Yes completed & 10 & 0.75 & 10 & 1.80 \\
\hline & No completed & 3 & 1.04 & 3 & 1.97 \\
\hline \multirow[t]{2}{*}{ Step 2 Setting health promotion priorities } & Yes completed & 8 & 0.80 & 8 & 1.78 \\
\hline & No completed & 3 & 1.04 & 3 & 1.97 \\
\hline \multirow[t]{2}{*}{ - Step 1+2 completed } & -Yes completed & 4 & 1.06 & 4 & 1.87 \\
\hline & -No completed & 10 & 0.50 & 9 & 1.82 \\
\hline \multicolumn{6}{|l|}{ Step 3 Identifying important and modifiable determinants } \\
\hline \multirow[t]{2}{*}{ there is a working group to examine the priorities } & Yes completed & 7 & 1.09 & 7 & 1.91 \\
\hline & No completed & 8 & 0.25 & 7 & 1.77 \\
\hline \multirow[t]{2}{*}{ activities are coordinated within the team } & Yes completed & 7 & 1.15 & 7 & 1.91 \\
\hline & No completed & 3 & 0.26 & 3 & 1.63 \\
\hline \multirow{2}{*}{$\begin{array}{l}\text { Step } 3 \text { Identifying important and modifiable } \\
\text { determinants }\end{array}$} & Yes completed & 4 & 1.37 & 4 & 1.95 \\
\hline & No completed & 8 & 0.25 & 7 & 1.77 \\
\hline \multirow[t]{2}{*}{ - Step $1+2+3$ completed } & -Yes completed & 2 & 1.11 & 2 & 1.90 \\
\hline & -No completed & 12 & 0.59 & 11 & 1.82 \\
\hline \multicolumn{6}{|l|}{ Tabel is continued on page 112} \\
\hline \multicolumn{6}{|c|}{ PA Satisfaction with the practical assistance } \\
\hline \multicolumn{6}{|c|}{ Satisfaction with the organizational competencies of the SHP advisor } \\
\hline \multicolumn{6}{|c|}{ Difference significant at the $p<.01$ level (2-tailed). } \\
\hline \multicolumn{6}{|l|}{ Difference significant at the $p<.05$ level (2-tailed). } \\
\hline \multicolumn{6}{|c|}{ t-test was not possible due to the small number of respondents in one of the group } \\
\hline
\end{tabular}


Table 3 (continued from page 111): Scores on satisfaction with the practical assistance (PA) and the organizational competencies $(\mathrm{OC})$ of the SHP advisor of schools that did complete a particular step of the Schoolbeat approach and schools that did not complete that step

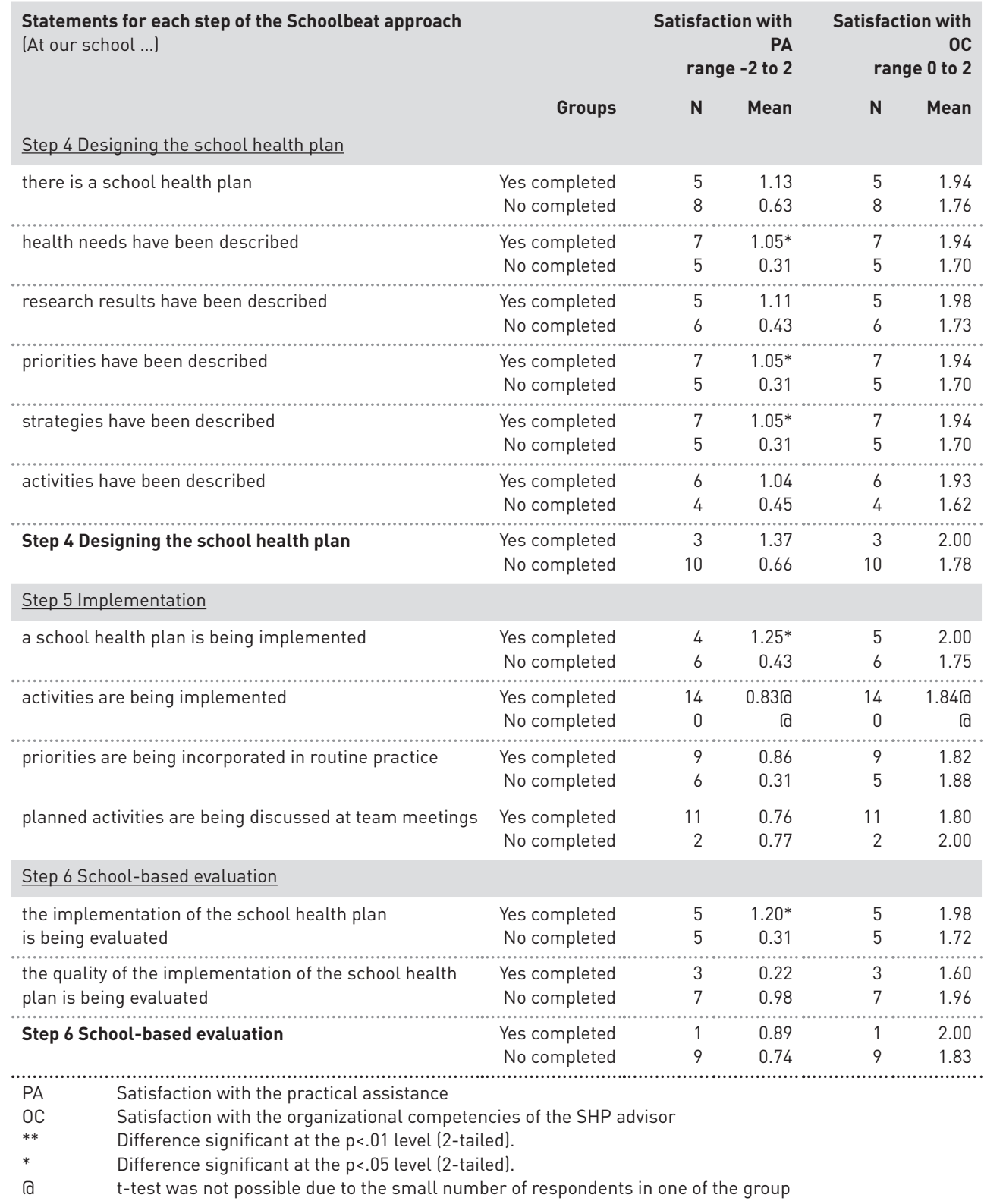


Table 3 shows that schools that were actively interested in health and safety were more satisfied in terms of both practical assistance and the organizational competencies of the SHP advisor. The schools that had implemented the activities belonging to step 4 (designing the school health plan) tended to be more satisfied with the practical assistance by their advisor, except as regards the presence of a school health plan and the description of research results and activities in the school health plan. Schools that had implemented and evaluated the school health plan reported more satisfaction with the practical assistance than schools that had not done so.

It appears that satisfaction with practical assistance is more predictive of the degree of implementation than satisfaction with professional competencies.

\section{Discussion and conclusion}

The main aim of this study was to evaluate the role of SHP advisors in the structural implementation of health promotion policies and programs in secondary schools.

Three research questions were addressed. The first question focused on the current implementation of the six steps of the Schoolbeat approach in the Southern Limburg region of the Netherlands. The results show that only one school had implemented the Schoolbeat approach as intended, although even then not fully: they had undertaken steps 1 to 5 , including all related activities. The other schools seemed to have selected activities that fitted their working procedures at specific moments. The results show that more practical activities like setting priorities for health promotion and implementing activities were more likely to be completed than the more complicated structuring steps such as writing a school health plan, describing health needs, describing research results and describing priorities. Relatively more activities from step 5 , the practical work of implementing health plans, were reported.

The original idea of the Schoolbeat approach was to create a linear process which schools can follow step by step when implementing school health policy, (Leurs, Jansen en anderen 2005) but this linearity was not reflected in the practical implementation of the approach. An explanation for the apparent preference for a cyclical model could be that schools are not obliged to develop preventive health policies: health promotion is not a prescribed part of the school curriculum. As a result of this autonomy, schools tend to implement only those elements of the Schoolbeat approach that fit their opportunities and working procedures. The linear model of the Schoolbeat approach as a whole does not seem to fit with their preferences. 
Nevertheless, the Schoolbeat approach could fulfill needs of schools if some adjustments were introduced. Assistance on demand appeared to be the key to success, within the limits of health promotion; this is precisely the main task of the SHP advisor. Based on our own research and other publications we conclude that the process is put to practice in an iterative cyclic process. Flexibility is necessary in assisting the school. This finding has important implications for the SHP advisor.

Every school has an SHP advisor to guide it in implementing the Schoolbeat approach, and the second research question was whether schools were satisfied with the practical assistance offered to them in implementing the steps of the program, and with the organizational competencies of their SHP advisor. The schools generally reported being satisfied with these aspects of the SHP advisor's performance. The questionnaire we used for both concepts showed consistent results.

The Schoolbeat approach is based on demand-driven assistance. The main task of the SHP advisor in each of the schools was to guide the school in the process of implementing a school health policy. Whereas satisfaction with the practical assistance related to professional skills and knowledge, satisfaction with the organizational competencies of the SHP advisor related to constructive personal relationships resulting from positive feelings. It seems that both aspects had a positive impact on the satisfaction of the school with the SHP advisor. Where there were no positive feelings about the organizational competencies of the advisor, there was no collaboration and the SHP advisors did not get an opportunity to use their professional skills and guide the school in the process of implementing structural health promotion programs and policies. On the other hand, if there were positive feelings about the organizational competencies and a personal relationship had developed, but the SHP advisor lacked sufficient professional skills and knowledge for practical advice, the advisor could not fulfill the task of assisting the school in implementing structural health promotion programs and policies. In such situations, the SHP advisors could not fulfill their promise and there was a risk that the trust they had gained was lost.

Although the organizational competencies were less predictive for implementation of the Schoolbeat approach, satisfaction with organizational competencies was relatively high. However we suggest that a certain level of trust based on organizational competencies is a prerequisite for introducing the Schoolbeat approach. Reports in the literature support the hypothesis of a positive impact of trust. Mutual trust is one of the factors the DISC model describes as crucial for successful collaboration, influencing the motivation for collaborative support (Leurs, Schaalma en anderen 2005; Leurs, Mur-Veeman en anderen 2008). 
The last research question was whether there was a relationship between the level of satisfaction with the practical assistance and the organizational competencies of the SHP advisor and the implementation of the Schoolbeat approach. Such a relationship was indeed found between the level satisfaction with the advisor's practical assistance and the implementation of certain items of the Schoolbeat approach, albeit mainly items from step 4, designing the school health plan. Although the practical activities of implementing health promotion activities from step 5 were far more common, satisfaction with practical assistance seemed to depend more on the planning and organizing activities from step 4. As regards satisfaction with the advisor's organizational competencies, such a relationship was only confirmed for one activity: attention for health and safety in the school.

Health promotion is a specialist subject which teachers and school managers do not learn in their training (SLO 2007; Staatscourant 2009). Also, health promotion is not the core business of schools, although they appear to be willing to implement a school health policy. The teaching profession feels responsible for fulfilling their social role, but they have neither the necessary knowledge nor the opportunity to invest much of their time in it. Whereas practical issues like implementing activities can probably be fitted into their daily task, developing policies do not belong to the daily routine of a school, this requires knowledge of health promotion policy, as well as time. Schools and teachers need someone who has the time, the professional skills and the knowledge to develop and implement structural health promotion programs and policies. Schools themselves remain responsible for school health policy, but they need support in building and executing this. It seems that the SHP advisor can fulfill this task.

Results of this study should be interpreted while bearing some limitations in mind. First, not all secondary schools in the Southern Limburg region agreed to participate. This selected target population could have influenced the results. Nevertheless, the target population did represent a majority of all the schools in Southern Limburg. Second, not all members of the school staff were willing to participate in the research, so the results give an incomplete picture of the staff population of the participating schools. However, information from regular contacts between the health promotion professionals in Southern Limburg and the non-response schools suggests that our results are representative of the current position of structural health promotion programs and policies within secondary education in Southern Limburg. Third, a relatively large group of respondents failed to answer the questions about the satisfaction of the advisors' practical assistance and the organizational competencies of the SHP advisor. Those who did answer the questions were generally satisfied. At school level, the majority of the prevention coordinators answered the questions, and their responses are representative of the entire school population. This is why we only report the relationship between the satisfaction of the advisor's prac- 
tical assistance and the organizational competencies and the implementation of the Schoolbeat approach at school level. Fourth, the results we found when relating satisfaction to completion of Schoolbeat steps allow the conclusion that there is a modestly positive influence. Due to the small group of respondents whose answers could be used in the school level analysis, the power of the t-tests is limited; all the difference between groups are in the same direction. It is thus likely that increasing the research sample would confirm the relation between satisfaction and implementation. Finally, only a few steps of the Schoolbeat approach have been fully implemented in practice. Our results are based on a sometimes marginal implementation of the Schoolbeat approach. Further research is necessary to investigate the effects of the SHP advisor when the Schoolbeat approach is completely implemented.

We suggest that implementation of school health promotion using the six steps of the Schoolbeat approach cannot be accomplished without schools being satisfied with practical assistance of their SHP advisor: although a relationship of trust is important, professional knowledge and skills are also crucial competencies for a successful SHP advisor. The Schoolbeat approach should be regarded as an educational innovation. Much information is available about the process that takes place when implementing an innovation, and important factors include characteristics of the organization and of the person who has to work with the innovation, the adoption strategy, the innovation and the environment (Rogers 1995; Shediac and Bone 1998; Fullan 2001; Fleuren, Wieferink en anderen 2004). The introduction of a personal advisor or innovation agent does not appear to have been investigated.

Our study shows that satisfaction with the SHP advisor can have a positive impact on the implementation of structural health promotion programs and policies. Conversely, if schools succeed in implementing structural health promotion programs and policies, the satisfaction with the SHP advisor will also rise.

Structural health promotion programs and policies are increasingly regarded as important in many countries, but still need further development. This study shows that an SHP advisor can make a positive contribution to health promotion in schools. Since this new task field demands new skills, the competencies of these health promotion professionals need to be further developed. 


\section{Hoofdstuk 5:}

\section{Implementation of school health promotion: consequences for professional assistance}

Ingediend als:

Boot, N.M.W.M., De Vries, N.K. (2010 (submitted))

Implementation of school health promotion: consequences for professional assistance. 


\section{Abstract}

This case study aimed to examine the factors influencing the implementation of health promotion (HP) policies and programs in secondary schools and the consequences for professional assistance.

Group interviews were held in two schools (best and worst case) in the Southern Limburg region. Both schools were represented by the school manager, the health care coordinator and their school health promotion (SHP) advisor. The main purpose of the group interview was to describe the organization of HP in the school.

Efforts to improve organizational aspects like change management, collaborative support and project management contributed to the implementation of HP.

Based on these results we advise SHP advisors to focus more on the organizational aspects of $\mathrm{HP}$ in schools.

This study contributes to the discussion about the tasks of HP professionals assisting secondary schools. Results show that effective assistance in shaping school health promotion requires competencies that go beyond organizing practical HP activities. HP professionals assisting schools need skills covering many aspects of the field, ranging from professional assistance for the process of implementing HP to organizational skills to advise and guide schools on the organizational changes needed for the implementation of HP. 


\section{Introduction}

Children's health is a frequently discussed topic in the educational setting (Aggleton, Rivers en anderen 2000). Improving the health of our population starts with improving that of our children. Nevertheless, interest in health promotion (HP) in schools is often limited (Stewart-Brown 2006; Davis and Cooke 2007).

This situation has led to the introduction of the concept of the 'health promoting school'. The main focus of this new approach is to systematically embed HP in schools and school policies. This approach has been adopted in many countries (St.Leger 2004; Clift, Jensen en anderen 2005), including the Netherlands (Leurs, Schaalma en anderen 2005; Bos, De Jongh en anderen 2010).

In the Netherlands, HP is not regarded as one of the main tasks of schools. Although schools feel responsible for HP, there is no legal obligation (SLO 2007; Staatscourant 2009). The core business of schools is to assist students in developing academic competencies and learning skills (Turkenburg 2008). Nevertheless, every secondary school has its own health care (HC) coordinator to guide students effectively when they encounter problems. This is an extra-curricular position, funded by the government. The HC coordinators have close ties with both management and teaching staff. Their main task is to assist students who encounter individual problems that affect their school achievements and behavior. Backed up by a team of representatives of various health care organizations (health care team), the $\mathrm{HC}$ coordinators guide students towards a solution for their problems. This approach is mostly health-care driven, with little attention for HP (Van der Steenhoven and Van Veen 2009).

The social function of schools has often been the subject of debate. Schools are seen as the most important point of access to children as regards many social problems (criminality, parenting problems, low self-esteem and many more) (Turkenburg 2008). As a consequence, many prevention organizations approach schools offering programs to solve such problems, so the educational system is swamped by requests. Due to this workload, schools at best give some ad hoc attention to HP, but mostly focus on care (Bos, De Jongh en anderen 2010).

In response to this situation, all regional organizations in Southern Limburg (the Netherlands) specializing in health, welfare, safety, individual student care and youth care joined forces in 2002. This group, coordinated by the regional public health service, aimed to improve the role of HP in schools and reduce the excessive workload described above (Leurs, Schaalma en anderen 2005). 
Efforts to reach this goal have involved the development of various initiatives within the so-called Schoolbeat approach (Leurs, Schaalma en anderen 2005). This approach includes six steps to facilitate the development of a cyclic and structured approach to school HP. Step one determines the health needs of the school population, based on available epidemiological data on the students, as well as data on their academic performance, and information about the school community as a whole. Step two involves setting HP priorities based on the information gathered in the first step, using the opinions of the school team, parents and students. In step three, important and modifiable determinants of priority problems are identified to select possible activities focusing on students, staff, school, school policy and the community. In step four, a school health plan is written on the basis of all the previous steps. Step five involves the implementation of the school health plan and activities and step six is a school-based evaluation.

Collaboration is essential for the implementation of the steps of the Schoolbeat approach in secondary schools (Leurs, Mur-Veeman en anderen 2008). This implementation requires organizational changes in schools and all regional partner organizations involved. To manage this, the Diagnosis of Sustainable Collaboration (DISC) model was developed. The DISC model is a theoretical framework for the various concepts lexternal factors, change management, context, project management and collaborative assistancel that influence the collaboration between relevant parties to implement an innovation like coordinated HP (Leurs, Mur-Veeman en anderen 2008). In the present study we used the DISC model to focus on the implementation of $\mathrm{HP}$ and the consequences for professional assistance in secondary schools in Southern Limburg.

The collaboration between parties has been managed by creating a "linking pin" system, in which each school has its own school health promotion (SHP) advisor, who represents all participating organizations and their professionalism and expertise. The SHP advisors advise schools on the implementation of activities and policies for specific themes, as well as assisting them in implementing the six steps of the Schoolbeat approach (Leurs, Schaalma en anderen 2005).

Schools are asked to appoint a contact person. As a point of access for the SHP advisor, this person is responsible for the organization of HP at the school. This task is often assigned to the school's HC coordinator.

All 25 secondary schools in Southern Limburg currently have an SHP advisor, for which a total of twelve SHP advisors have been trained to assist them. After eight years of practical experience with highly variable progress in different schools, this made an interesting subject for research. The present study addressed the following research question: "What factors influence 
the implementation of HP policies and programs in secondary schools, and what are the consequences for professional assistance?"

\section{Methods}

This case study took place in June through September 2008 in two secondary schools in Southern Limburg.

\section{Case selection}

We selected two extreme cases in terms of the degree of implementation, the "best" and the "worst" case. The selection was based on the results of a questionnaire study (the full study is reported in (Boot, Van Assema en anderen 2010)). In this previous study, the persons at each of the schools who were most knowledgeable about the Schoolbeat approach (the HC coordinator or a school manager) and the SHP advisors of 19 secondary schools filled out a questionnaire about the implementation of the Schoolbeat approach. The questionnaire consisted of 20 statements addressing the implementation of the six steps of this approach. Two examples of the statements are: "A school health plan has been implemented at our school" and "Priorities for HP have been set at our school"; (answer options: yes, no). A step was considered to have been fully completed if all statements regarding that step were answered affirmatively by both the representative of the school and the SHP advisor. As the "worst case" in the present study we selected the school that had implemented the fewest Schoolbeat steps, while the "best case" was the school that had implemented the most steps. This article only describes the situation at these two schools.

\section{Respondents}

The case study was based on two group interviews, one in each school, involving the $\mathrm{HC}$ coordinator and a school manager to represent each school, and the school's SHP advisor representing all regional public health services. The interviews were held by the manager of the department of HP of the regional public health service. Both interviews were taped.

\section{Interviews}

The six steps in implementation of the Schoolbeat approach were used as guidelines for the interviews at the schools. Our case study further used the Diagnosis of Sustainable Collaboration (DISC) model as a theoretical framework (Leurs, Mur-Veeman en anderen 2008), to interpret the process of implementing HP. The main interview topics, derived from the DISC model, were: external factors, change management, context, project management and collaborative support. The interviews had two goals: understanding the organizational aspects of the imple- 
mentation of the Schoolbeat approach in these two schools, and identifying factors that influence the implementation process.

\section{Analysis}

The interviews were analyzed using NVivo 8. Both interviews were typed out verbatim. Text fragments were initially coded using the interview protocol.

\section{Results}

\section{Validation of the case selection}

The "best case" reported that all activities of the various Schoolbeat steps had been implemented, except the evaluation. The SHP advisor's opinion differed slightly from the school's point of view.

The "worst case" school had not successfully implemented any of the six Schoolbeat steps. Only a few activities had been carried out. Activities to achieve systematic implementation, like establishing a framework for prevention activities and a school health plan, had not been carried out. The answers of the SHP advisor differed in some respects, but there were no major differences as regards systematic implementation.

\section{External factors}

According to the DISC model, external factors are those factors that influence the collaboration process but are beyond the control or influence of the collaborating organizations (school and SHP advisor) themselves.

Schools have no legal obligation to implement HP. Both schools stated that their legal obligation was to offer high quality education to children. In addition, they were already faced with many extra tasks. Schools were overloaded with work, and teachers and school managers already felt stretched to the limit. To reduce this load and ensure the quality of education, they were very apprehensive about taking on extra tasks. Although the schools might feel responsible for the health of their students, they could no longer count on the willingness of individual teachers to to help improve student health, and without the cooperation of teachers, it was difficult to implement HP. 
In this respect, there was no difference between the best and worst cases.

\section{Change management}

The DISC model describes that the implementation of HP requires management. Leadership skills are necessary to stimulate school managers and teachers, and to guide the implementation process.

The respondents reported that the leadership of the SHP advisor had encouraged them in their task of implementing HP.

"The SHP advisor stimulates us. If she wasn't there, nothing would happen."

School 2

Both schools reported being satisfied about the assistance offered by the SHP advisor.

"I'm very pleased with our SHP advisor. She is very accessible and accurate. So I could

not do without her."

School 2

As regards the leadership skills in the schools, the best case had explicitly assigned the task of coordinating $\mathrm{HP}$ activities to one of its team members, the health care $(\mathrm{HC})$ coordinator. This person was in frequent contact with the school manager to report on the most important activities. The coordinator was responsible for overseeing the process as a whole, as well as for the coordination and implementation of the Schoolbeat steps. The SHP advisor guided the coordinator in fulfilling this task.

"Someone has to be responsible for the implementation of HP at the school. Otherwise

it will fail. We cannot depend entirely on people's voluntary efforts."

School 1

The worst case had not explicitly assigned to anyone the task of coordinating HP activities at the school. There was no strong leader at the school with time for HP.

Our analysis of this aspect of the DISC model suggests that the presence of a leader has a favorable influence on the implementation of HP. 


\section{Context}

According to the DISC model, the collaborative process evolves in a context which can be influenced by the collaborative partners themselves. If parties have had positive experiences with each other in previous collaborative processes and feel supported, they have a more open attitude towards the sustainable collaborative process supporting inter-sectoral HP.

In the best case, the task of coordinating HP activities was combined with the function of $\mathrm{HC}$ coordinator. There is a strong link between these two task fields.

\section{"HC coordinators have a crucial signaling function. They know what happens at the school."}

The $\mathrm{HC}$ coordinator already cooperated with various health care organizations participating in the Schoolbeat approach. The HC coordinator had a strong sense of responsibility for the health of the students. Whereas HC focuses on individuals, HP is primarily aimed at the collective. Individual students who are at risk or have problems were discussed in the $\mathrm{HC}$ team, and the input of the HC team was essential for setting HP priorities.

In the worst case, there was no link between HC (individual pupil care) and HP.

"HC and HP are often seen as one task, but I think it is difficult to combine these two

The $\mathrm{HC}$ coordinator was not involved in $\mathrm{HP}$, and there was no interaction between the two task fields, due to a lack of structure.

Linking the tasks of the $\mathrm{HC}$ coordinator to HP activities seemed to have a positive influence on the implementation of HP.

\section{Project management}

The DISC model describes how during the development and initial implementation phase, the collaborative process is dealt with as a project in a project management structure.

The best case had organized the project management structure by appointing a special prevention team under the supervision of the $\mathrm{HC}$ coordinator, who also had the extra task of coordinating the HP activities. This prevention team assisted the $\mathrm{HC}$ coordinator in implementing HP 
activities in the school as a whole. The school staff was organized in year teams, one team for each school year. The year teams were responsible for the coordination of teaching and other activities in their year. Every year team had its own representative in the prevention team, who was responsible for the coordination between the prevention priorities and activities of their own year team and the prevention priorities and activities of the other year teams.

"The representatives of the teams have to say: our team needs this, what can the preven-

tion team offer to meet this need? That's where the input for priorities comes from."

School 1

The prevention team, which met every three months, included not only teachers but also representatives from the student council and the parents' council. In addition to the meetings of the prevention team, there were monthly meetings between the $\mathrm{HC}$ coordinator and the coordinator of each year team, at which various HP-related aspects were discussed and coordinated.

The worst case had started its own prevention team in 2002, under the supervision of the school manager. The team consisted of a biology teacher, a PE teacher, parents and students. After a period of reorganization, HP activities were given lower priority, and the prevention team ceased to exist.

"When we started we had a strong group. In time, the priorities changed and the interest faded."

In 2008, a new prevention team was started, again under supervision of the school manager. This team consisted of the school manager and two other people: the HC coordinator and the SHP advisor. There was no interaction with the greater part of the school's teaching staff, students or parents, and there was no organizational structure for HP at the school.

Embedding HP in the school management structure appears to have a positive impact on the implementation.

\section{Collaborative support}

The DISC model specifies collaborative support at three levels: perceptions (what is the opinion of the parties about collaboration?); intentions (do the parties plan to collaborate?) and actions lare the parties going to collaborate?). 
In the best case, the school manager was positive about the collaboration and had taken action to organize the collaboration between the SHP advisor and the school. The HC coordinator had been allocated extra time for the coordination of HP activities. Although the government does not provide structural funding for HP activities in schools, the school manager had given a small working budget of 2000 euros to each year team for HP activities. In addition to the standard teaching hours, each teacher had extra-curricular hours allocated for tasks like organizing the school theater, student counseling or prevention activities. The team coordinator was responsible for assigning these extra tasks, one of which was to represent the year team in the prevention team and assist the HC coordinator in the coordination and implementation of HP activities.

"We trust that the team coordinator will allocate one person in their team to do the HP."

School 1

In the worst case, the school manager was positive about collaboration, and did intend to initiate action to organize systematic collaboration between the SHP advisor and the school, but had not succeeded in the action phase. The school manager himself was taking care of the coordination of HP activities, but he did not have extra time available for this task. There was no working budget for HP activities. Most of the school's population of teachers, students and parents were not involved. Initially, there had been a positive atmosphere at the school, as all teachers were willing to assume extra tasks besides teaching. By now, however, everybody had such a high workload and the positive attitude had turned negative. HP had no priority at this school. According to the school manager, the enthusiasm for HP would not return as long as no extra time was allocated to HP activities.

"Last year all efforts have faded due to reorganizations. It's sad but in times of reorganization, HP is no longer a priority"

It appears that schools need to have the opportunity to act upon such intentions; positive perceptions and intentions are not enough.

\section{Discussion and conclusion}

This case study tried to analyze the implementation process of health promotion (HP) in secondary schools, and the consequences for professional assistance. We compared two schools in the 
Southern Limburg region of the Netherlands, the "best case" and "worst case", in terms of the implementation of the steps of the Schoolbeat approach, by describing how the implementation of HP at the schools was organized, based on the concepts of the DISC model. Our findings from interviews showed differences between the two cases in the organizational aspects of the implementation of HP.

The two cases differed in terms of all concepts of the DISC model, except for that of external factors. The best case had a strong prevention team with representatives of every sector of the school (staff, students, parents), whereas the worst case had only a small team of three people planning activities for the whole school. The best case had an internal leader who regarded HP as her task, whereas the worst case had a leader who did not play an active role as she did not have enough time. These differences could be either causes or effects of the difference in implementation between the two schools. The following factors might explain the difference in implementation of the Schoolbeat steps.

The first is the difference between the two cases in terms of change management. Implementing a new idea requires an effective change agent, someone who can convince the school of the benefits and who guides the process of change (Leurs, Mur-Veeman en anderen 2008). The two schools we studied differed in terms of organization. The best case had a strong leader, who was willing to guide the team, whereas the worst case had allocated this task to the school manager, without however allocating extra time.

The second factor was the difference between the two cases in terms of collaborative support. The DISC model states that an innovation cannot succeed without collaborative support (Leurs, Mur-Veeman en anderen 2008). The school has to have at least the intention to collaborate, and there has to be consensus about priorities, commitment and formalization to bring about action. In the best case, there was a prevention team with a strong leader, the HC coordinator. Each of the school's "year teams" had its own representative on this team, with dedicated hours for their contribution to the prevention team. The priorities that had been set were decided by the year teams, and there was clear commitment. The worst case, by contrast, had no link between the prevention team and the school's population of teachers, students and parents. Priorities were set by only three people, and there was no commitment to HP. The best case had implemented nearly all steps of the Schoolbeat approach, whereas the worst casewas lagging far behind.

Thirdly, there was a difference between the two schools in terms of project management. Project management is based on the interaction between three important factors: who (actors); what (tasks and roles); and how (structure and meetings) (Leurs, Mur-Veeman en anderen 2008). This project management is necessary for the structural implementation of an innovation. Whereas 
the best case had regular meetings at different levels of the organization, the worst case only had regular meetings between the three members of the prevention team.

The fourth potential factor, satisfaction with the SHP advisor, did not seem to make any difference. Both schools were satisfied with the assistance provided by the SHP advisor. This could be explained by the fact that schools have no obligation to implement HP activities; it is their decision, which might mean that the targets that schools set for HP are low. They are glad that there is a person who assists them in implementing $\mathrm{HP}$, and quality is of secondary importance.

The results of this study should be interpreted while bearing some limitations in mind. First, although these two cases showed clear differences in terms of the implementation of HP, these results were found retrospectively. The results are based on the subjective impressions of the SHP advisors and the representatives of both schools. However, the results seem to agree well with those of previous studies using the DISC model. (Leurs, Mur-Veeman en anderen 2008).

Second, the results are based on only two secondary schools in Southern Limburg. However, the selection of these two schools was based on the results of a survey among 19 secondary schools in the region, from which we selected the best and the worst case in terms of the implementation of the steps of the Schoolbeat approach. We therefore think that the results of this study can be generalized to the wider population of schools in Southern Limburg.

Third, the interviews were held with multiple staff members of one school present at the same time, which may have elicited socially desirable answers. We tried to minimize the consequences of this for the conclusions by validating the interview results with the opinions of the SHP advisors, including their opinions as external advisors for the organization of HP at both schools.

This study showed that change management, collaborative support and project management have a positive impact on the implementation of the Schoolbeat approach. Based on these results, we recommend that SHP advisors explicitly focus on these organizational aspects. The task of HP professionals assisting schools goes beyond organizing practical HP activities. Such HP professionals need skills covering many aspects of the field, ranging from professional assistance in the process of implementing the Schoolbeat approach to organizational skills needed to advise and guide schools through the organizational changes needed for the systematic implementation of HP.

This conclusion contributes to the discussion about the tasks of HP professionals. Whereas in the past, these professionals focused on carrying out practical HP activities, their focus is now shifting to more organizational aspects like project management, collaborative support in professional networks and change management. 


\section{Hoofdstuk 6:}

\section{Evaluatie van de schoolslag-checklist gericht op het beoordelen van schoolse interventies}

\section{Gepubliceerd als:}

Boot, N.M.W.M., Leurs, M.T.W., Peters, L.W.H., Keijsers, J.F.E.M., Schaalma, H.P., en De Vries, N. (2005). Evaluatie van de schoolslag-checklist gericht op het beoordelen van de kwaliteit van schoolse interventies. Tijdschrift voor Gezondheidswetenschappen, 83(7), 405-411. 


\section{Samenvatting}

Ongezond gedrag onder de jeugd neemt toe. Dit vraagt om structurele aandacht van zowel het preventie- als het onderwijsveld.

In Nederland zijn talloze gezondheidsbevorderende programma's beschikbaar. Over de kwaliteit ervan is echter weinig bekend. De schoolslag-checklist is ontwikkeld om inzicht in de kwaliteit van programma's te geven zodat instellingen en scholen mede op basis van kwaliteit keuzes kunnen maken ter versterking van school(gezondheids)beleid.

Om de kwaliteit van de checklist te bepalen en waar mogelijk te verhogen is onderzoek uitgevoerd naar de validiteit, betrouwbaarheid en bruikbaarheid van de checklist. Voor het bepalen van de validiteit van de checklist hebben 21 experts op het gebied van preventie en 1 uit het onderwijs hun mening gegeven over de mate waarin geselecteerde kwaliteitscriteria leffectiviteit; efficiëntie; aandacht voor wensen scholen/klantgerichtheid; aandacht voor sociale en fysieke omgeving; aandacht voor relaties/betrokkenheid bredere gemeenschap; aandacht voor relaties/betrokkenheid andere instellingen; aandacht voor kwaliteit van leraren; training, ondersteuning, bevorderen van vaardigheden; participatie van alle betrokkenen in planning, ontwikkeling en uitvoering: ownership; ethische principes) voldoende terugkomen in de schoolslag-checklist. Van hen was 60\% van mening dat de kwaliteitscriteria voldoende vertegenwoordigd zijn in de schoolslag-checklist. Op basis van beide onderzoeksdelen is de schoolslag-checklist 1.2 samengesteld.

Voor het bepalen van betrouwbaarheid en bruikbaarheid hebben 29 onderwijsgevenden en 25 GVO/preventiefunctionarissen vier bestaande preventieprogramma's beoordeeld met de checklist. De schoolslag-checklist werd door $73 \%$ van de respondenten als waardevol en door $65 \%$ als duidelijk beoordeeld. Betrouwbaarheidsanalyses tonen een aanvaardbare tot hoge interne consistentie, met Cronbach's alpha's variërend van 0,64 tot 0,92. Conclusie: de schoolslag-checklist 1.2 is een intern consistent en bruikbaar instrument voor het bepalen van de kwaliteit van schoolse interventies. Om nauwkeurige uitspraken te kunnen doen over de validiteit van het meetinstrument is nader onderzoek gewenst. 


\section{Inleiding}

Onder jongeren komt ongezond gedrag vaak voor (de Vreede, Rademaker en anderen 2003; Ministerie van Volksgezondheid 2003) en preventie blijft dan ook nodig (VNG, GGD Nederland en anderen 2003). In het onderwijs wordt reeds lang aandacht besteed aan gezondheidsbevordering en ziektepreventie. Het aanbod aan programma's voor scholen is echter zo versnipperd en onoverzichtelijk, dat veel scholen door de bomen het bos niet meer zien. Scholen hebben behoefte aan ondersteuning dicht bij huis, een regionaal loket waar zij met hun vragen over gezondheidsbevordering terecht kunnen (Pijpers 1999). Om aan deze wens te kunnen voldoen hebben de verschillende gezondheids- en onderwijsinstellingen in de regio MaastrichtMergelland hun krachten gebundeld om een werkwijze te ontwikkelen voor een systematische en planmatige vormgeving van vraaggestuurd schoolgezondheidsbeleid, "schoolslag" (Leurs 2003; Leurs, Schaalma en anderen 2005).

Om het schoolgezondheidsbeleid goed in te kunnen vullen is onder andere informatie nodig over de kwaliteit van preventieprogramma's voor het gebruik in het onderwijs. Uit recent werk van het Trimbos-instituut blijkt wederom dat er weinig bekend is over de kwaliteit van preventieprogramma's in Nederland gericht op kinderen en jongeren (Verdurmen, Van Oort en anderen 2003). Bij de ontwikkeling van de schoolslag-werkwijze ontstond daarom de behoefte aan een handzaam, beknopt kwaliteitsmeetinstrument, dat inzetbaar is in het onderwijs en het preventieveld. Om dit te kunnen realiseren hebben NIGZ, GGD Zuidelijk Zuid-Limburg en Universiteit Maastricht op basis van een review en expert-consultaties een kwaliteitschecklist ontwikkeld; de schoolslag-checklist (Peters, Leurs en anderen 2004). Deze checklist richt zich op het identificeren en selecteren van kwalitatief goede schoolgerichte interventies, ter versterking van school(gezondheids)beleid. Bij de ontwikkeling van de checklist is onder meer gebruik gemaakt van reeds bestaande kwaliteitsinstrumenten zoals het Preventie Effectiviteit Instrument (Preffi), een hulpmiddel bij programma-ontwikkeling en bij interne, en in mindere mate externe, kwaliteitsbeoordeling van preventieprogramma's (Peters, Leurs en anderen 2004). Terwijl de Preffi 2.0 vooral bedoeld is als planningsinstrument en instrument voor interne kwaliteitsbeoordeling is de checklist vooral bedoeld als extern beoordelingsinstrument (Molleman and Hosman 2003; Molleman, Peters en anderen 2003; Peters, Leurs en anderen 2004). Kennis kan gewogen en gedeeld worden. Dit sluit aan bij het kwaliteitsdenken, een van de inspiratiebronnen bij de recente ontwikkeling van het Referentiekader Gezondheidsbevordering (Saan and De Haes 2004). De schoolslag-checklist kan in dit referentiekader ingezet worden in de analyse van schoolse interventies. De checklist kan daarmee de waarde van het referentiekader op het terrein van stimuleren en faciliteren van communicatie over gezondheidsbevordering versterken (De Vries 2004). Een spin-off richting kwaliteitsverbetering van projectontwikkeling 
op het terrein van de gezonde school behoort zeker tot de mogelijkheden. Dit artikel beschrijft het onderzoek naar de validiteit, betrouwbaarheid en bruikbaarheid van de schoolslag-checklist en doet een aantal aanbevelingen voor de praktijktoepassing van het instrument.

\section{Opbouw van het onderzoek}

Voor het onderzoek is de schoolslag-checklist versie 1.0 als uitgangspunt genomen (Peters, Leurs en anderen 2004). Deze checklist is opgebouwd uit 31 vragen verdeeld over negen kwaliteitscriteria laangetoonde effectiviteit, planmatigheid, efficiëntie ondersteunende instelling, efficiëntie school, onderwijsgerichtheid, participatie, aandacht voor de omgeving, kwaliteit van begeleiding ondersteunende instelling, diversiteit). Het onderzoek bestond uit drie elementen. Figuur 1 geeft een overzicht van de onderzoeksopbouw. Hierna volgt een beschrijving van de methoden en resultaten van de drie verschillende onderdelen van het onderzoek.

\section{Onderzoek 1 Pretest}

De schoolslag-checklist 1.0 is eerst kleinschalig toegepast. Dit gebeurde door tien personen (3 uit het onderwijsveld, 4 van regionale preventie instellingen en 3 medewerkers van landelijke preventie organisaties). Bij de preventieorganisaties / instellingen ging het veelal om personen die betrokken waren geweest bij de ontwikkeling van de checklist. De deelnemers hebben ieder twee veelgebruikte preventieprogramma's beoordeeld met behulp van de checklist. Ze gebruikten hierbij publiekelijk beschikbare schriftelijke informatie lverzameld en samengesteld door de onderzoeker) en foldermateriaal. Na afloop zijn de tien onderzoekspersonen geïnterviewd over hun ervaringen met het invullen van de checklist.

\section{Resultaten pretest}

Uit de pretest bleek dat docenten de schoolslag-checklist 1.0 te weinig toegespitst vonden op het onderwijs en te veel op het gezondheidsdomein. Daarnaast gaven vrijwel alle onderzoekspersonen aan problemen te hebben met het beoordelen van de criteria die buiten hun deskundigheidsgebied vallen. De docenten hadden moeite met de items gericht op de ontwikkeling, planning en evaluatie van de preventieprogramma's; de preventiedeskundigen met items gericht op de praktische uitvoerbaarheid van programma's in het onderwijs. 


\section{Onderzoek 1}

Pretest - bruikbaarheid

schoolslag-checklist versie 1.0

Aanpassing schoolslag-checklist

\section{Onderzoek 2}

Onderzoek validiteit

schoolslag-checklist versie 1.1

Aanpassing schoolslag-checklist

\section{Onderzoek 3}

Onderzoek bruikbaarheid / betrouwbaarheid schoolslag-checklist versie 1.2

schoolslag-checklist@ versie 1.2

Figuur 1: Schematische weergave van de opbouw van het onderzoek.

Op basis van deze gegevens is ervoor gekozen om de schoolslag-checklist op te splitsen in twee delen: een deel met kwaliteitscriteria die relevant worden geacht door het onderwijs, en een deel met kwaliteitscriteria die relevant worden geacht door de preventiesector. Deze twee delen vormen samen de schoolslag-checklist 1.1. Het onderwijsdeel bevat 24 items verdeeld over zes kwaliteitscriteria. In het preventiedeel zijn 25 items verdeeld over zeven criteria. Vier van deze criteria komen in beide lijsten voor. Daarnaast zijn de vragen gericht op het onderwijs uitgebreid met onder andere vragen gericht op de flexibiliteit en vormgeving van het preventieprogramma. Tot slot is de terminologie van de verschillende items beter afgestemd op het onderwijspersoneel. Zo is bijvoorbeeld het woord interventie vervangen door programma. De genoemde wijzigingen hebben geleid tot de schoolslag-checklist 1.1. 


\section{Onderzoek 2: Validiteit}

Bij het onderzoek naar de face-validiteit van de schoolslag-checklist 1.1 is ervoor gekozen om de checklist voor te leggen aan experts (onderwijs- en preventiedeskundigen). Pogingen om een evenredige verhouding tussen deze groepen te bewerkstelligen hadden geen succes omdat de respons uit het onderwijs met één persoon zeer gering was. Dit leidde ertoe dat het expertpanel bestond uit tweeëntwintig personen uit het preventieveld en één persoon uit het onderwijsveld. Deze personen zijn via de praktijk en/of via onderzoek professioneel betrokken bij de kwaliteit van de ontwikkeling, implementatie, uitvoering of evaluatie van preventieprogramma's op zowel regionaal als landelijk niveau. Aangezien ervoor gekozen is om de deelnemers te werven buiten het toepassingsgebied van de schoolslag-werkwijze (regio Maastricht-Mergelland) kon er geen gebruik worden gemaakt van de aldaar bestaande contacten in het onderwijs. Hiervoor is gekozen om de contacten in de eigen regio niet te veel te belasten daar zij al op verschillende andere manieren zijn betrokken bij de ontwikkeling van de schoolslag-werkwijze en bijbehorend onderzoek.

Om te kunnen bepalen op welke criteria de nadruk wordt gelegd bij het bepalen van de kwaliteit van preventieprogramma's, zijn de deelnemers gevraagd om een rangorde aan te brengen in een lijst van kwaliteitscriteria op een schaal van 1 (onbelangrijk) tot 10 (zeer belangrijk). Deze lijst is samengesteld op basis van de kwaliteitsreview die ten grondslag lag aan de 1.0 versie (Peters and Keijsers 2002). Vervolgens is gevraagd om per kwaliteitscriterium op een vijf-puntsschaal aan te geven of dit voldoende wordt gemeten met de schoolslag-checklist 1.1. Tevens is de mogelijkheid geboden om in open vragen aan te geven waarom men de verschillende checklist-criteria juist wel of niet voldoende vond uitgewerkt om de kwaliteit van preventieprogramma's te kunnen meten.

\section{Resultaten validiteit}

Op basis van de aangebrachte rangorde in kwaliteitscriteria en de oordelen op de vraag of naar mening van de deelnemers de kwaliteitscriteria voldoende terugkomen in de schoolslagchecklist kan een keuze worden gemaakt voor het wel of niet uitbreiden van de criteria (Tabel 1). Uit de rangorde die de respondenten hebben aangebracht in de kwaliteitscriteria blijkt dat "klantgerichtheid" het belangrijkste werd gevonden met een gemiddelde score van 7,6 op een schaal van 1 tot 10 . "Betrokkenheid van de bredere gemeenschap" bleek het minst belangrijk met een score van 4,9.

Tabel 1 geeft een overzicht van de gemiddelde rangorde per criterium. De rechterkant van de tabel geeft middels percentages aan hoeveel deelnemers vonden dat de criteria voldoende worden gemeten met de checklist. 


\begin{tabular}{|c|c|c|}
\hline Kwaliteitscriterium & $\begin{array}{r}\text { Gemiddelde rangorde } \\
\text { Schaal } 1-10\end{array}$ & $\begin{array}{l}\% \\
\text { ja }\end{array}$ \\
\hline Klantgerichtheid t.a.v. het onderwijs & 7,57 & 55 \\
\hline $\begin{array}{l}\text { Effectiviteit, doeltreffendheid, degelijke theoretische } \\
\text { principes }\end{array}$ & 7,50 & 52 \\
\hline Participatie in planning en uitvoering & 6,52 & 64 \\
\hline Efficiëntie, doelmatigheid & 6,10 & 66 \\
\hline Bevorderen van vaardigheden bij docenten en leerlingen & 5,95 & 44 \\
\hline Aandacht voor kwaliteit van leraren, training, ondersteuning & 5,86 & 60 \\
\hline Aandacht voor sociale en fysieke omgeving & 5,65 & 65 \\
\hline Aandacht voor relaties/betrokkenheid andere instellingen & 5,64 & 65 \\
\hline Ethische principes & 5,19 & 75 \\
\hline $\begin{array}{l}\text { Aandacht voor relaties/ betrokkenheid bredere } \\
\text { gemeenschap }\end{array}$ & 4,90 & 70 \\
\hline
\end{tabular}

$36 \%$ van de respondenten geeft aan dat participatie in planning en uitvoering onvoldoende wordt getoetst in de checklist. In de rangorde staat dit criterium met een score van 6.5 op de derde plaats. De respondenten geven aan waarde te hechten aan het meten van planmatigheid van de preventieprogramma's maar vinden dit criterium op dit moment nog onvoldoende uitgelicht. Op grond hiervan zijn voor het kwaliteitscriterium planmatigheid vier items toegevoegd. Daarnaast is de lijst uitgebreid met een item gericht op "de effectiviteit, doeltreffendheid, degelijke theoretische principes "( $48 \%$ van de respondenten vond dit onvoldoende uitgelicht terwijl het de tweede plaats in de rangordening inneemt met een score van 7.5), een item gericht op "klantgerichtheid " (45\% onvoldoende uitgelicht, plaats 1 in de rangorde met een score van 7.6), en een item gericht op "de implementatie van het programma". Dit werd herhaaldelijk genoemd als gemis in de checklist. Inclusief de herziening van een aantal formuleringen (zowel van items als van toelichtingen erop) heeft dit de schoolslag-checklist 1.2 opgeleverd, bestaande uit 31 items gericht op preventie en 26 items gericht op het onderwijs.

\section{Onderzoek 3: Betrouwbaarheid en bruikbaarheid}

Voor het onderzoek gericht op de betrouwbaarheid en bruikbaarheid van de schoolslag-checklist 1.2 is gebruik gemaakt van een onderzoekspopulatie bestaande uit vierenvijftig respondenten, afkomstig uit het onderwijs (29), het regionale gezondheidsveld (21) en het landelijke veld op het gebied van gezondheidsbevordering en preventie (4). De deelnemers hebben ieder vier 
preventieprogramma's beoordeeld op basis van promotiemateriaal bestaande uit een folder afkomstig van de leverancier van het betreffende programma met een korte beschrijving van het programma en de verschillende te bestellen materialen, en uitgebreide beschrijvingen van alle publiekelijk beschikbare informatie over het betreffende programma, opgesteld door de onderzoeker. Het was helaas niet mogelijk om alle respondenten te voorzien van het complete lesmateriaal van het betreffende programma. Omdat dit deel van het onderzoek als doel had de checklist te beoordelen op betrouwbaarheid en bruikbaarheid en niet het komen tot een betrouwbare en valide beoordeling van de kwaliteit van de voorgelegde preventieprogramma's konden we hiermee volstaan. De beoordeling van de preventieprogramma's bestond uit drie stappen, (1) het doorlezen van de programmabeschrijvingen en het toekennen van een intuïtief rapportcijfer over de kwaliteit, (2) Het invullen van de schoolslag-checklist per programma en (3) opnieuw toekennen van een rapportcijfer voor de kwaliteit met een argumentatie waarom het cijfer was veranderd of juist niet. Door een vergelijking te maken tussen de verschillende meetmomenten kan de invloed van de checklist op de beoordeling van kwaliteit worden bepaald. $\mathrm{Na}$ de beoordeling van de vier preventieprogramma's vulden respondenten ten slotte een vragenlijst in over onder andere de bruikbaarheid van de schoolslag-checklist en de bijbehorende instructie en toelichting.

Voor de analyse van de resultaten is gebruik gemaakt van het statistische verwerkingsprogramma SPSS 10.0. Voor resultaten betreffende de bruikbaarheid van de schoolslag-checklist zijn gemiddelden en percentages berekend. Daarnaast zijn beide onderzoeksgroepen londerwijs en preventiel vergeleken met een t-toets. Voor de bepaling van de betrouwbaarheid van de schoolslag-checklist in de vorm van interne consistentie zijn verschillende analyses uitgevoerd: betrouwbaarheidsanalyse, regressie-analyse en een variantie-analyse.

\section{Resultaten bruikbaarheid}

Tabel 2 (pagina 137) bevat een overzicht van de belangrijkste resultaten aangaande de bruikbaarheid van de schoolslag-checklist in de vorm van een percentage verdeling. De meeste scores zijn licht positief en geven aan dat de respondenten de checklist aanvaardbaar vinden. Gesteld in termen van percentages vindt $63 \%$ van de respondenten de checklist duidelijk tot zeer duidelijk en waardevol tot zeer waardevol. $14 \%$ van de respondenten beoordeelt de checklist als enigszins onduidelijk en enigszins overbodig. De overige respondenten geven een neutraal oordeel.

Er werden geen significante verschillen aangetoond tussen de oordelen van de twee onderzoeksgroepen (onderwijs en preventie). Het nut van de checklist voor het eigen werkveld werd in beide groepen hoger gewaardeerd dan het nut voor de desbetreffende persoon zelf. De mogelijkheid dat collega's wellicht baat hebben bij het gebruik van de checklist laten ze hiermee 
Tabel 2: meningen van 54 professionals (25preventie en 29onderwijs) in percentages over de gehele schoolslagchecklist@ 1.2 (op een vijf-punt schaal; $2 \mathrm{t} / \mathrm{m}-2$ )

\begin{tabular}{|c|c|c|c|c|c|c|c|c|c|}
\hline \multicolumn{8}{|c|}{ Percentageverdeling } & \multirow[t]{2}{*}{ Gem. } & \multirow[t]{2}{*}{ SD } \\
\hline Ik vind de schoolslag-chec & 1.2: & & & & & & & & \\
\hline overzichtelijk & 26 & 37 & 31 & 6 & & 0 & onoverzichtelijk & 0,82 & 0,89 \\
\hline waardevol & 23 & 40 & 23 & 14 & 0 & & overbodig & 0,73 & 0,97 \\
\hline duidelijk & 15 & 48 & 23 & 14 & 0 & & onduidelijk & 0,65 & 0,90 \\
\hline compleet & 17 & 37 & 35 & 12 & 0 & & onvolledig & 0,60 & 0,91 \\
\hline prettig & 21 & 29 & 33 & 17 & 0 & & vervelend & 0,54 & 1,02 \\
\hline makkelijk & 12 & 40 & 25 & 21 & 2 & & moeilijk & 0,38 & 1,01 \\
\hline te kort & 0 & 12 & 60 & 17 & 12 & & te lang & $-0,29$ & 0,82 \\
\hline te compact & 0 & 18 & 63 & 14 & 4 & & te uitgebreid & $-0,08$ & 0,74 \\
\hline \multicolumn{10}{|c|}{ Ik vind de schoolslag-checklist 1.2 nuttig: } \\
\hline voor mijn werkveld & 38 & 42 & 16 & 2 & 2 & & niet voor mijn werkveld & 1,12 & 0,88 \\
\hline voor evaluatie & 31 & 44 & 146 & & & 6 & niet voor evaluatie & 0,88 & 1,10 \\
\hline voor projectontwikkeling & 33 & 33 & 234 & & & 8 & niet voor projectontw. & 0,79 & 1,18 \\
\hline voor mijzelf & 23 & 34 & 1514 & & & 15 & niet voor mijzelf & 0,35 & 1,38 \\
\hline
\end{tabular}

open. Zowel preventie als onderwijs geven aan de checklist redelijk nuttig te vinden voor hun werkveld met een gemiddelde score van 1.00 en 1.45 , respectievelijk.

De gebruikswaarde van de checklist ligt volgens de respondenten vooral in de oordelen die uit de checklist voort kunnen komen (92\%), en niet zozeer in de eigen toepassing van de checklist $(52 \%)$. Het willen gebruiken van de oordelen ten behoeve van het eigen werk is, met name onder de preventiewerkers (95\%), populairder (85\%). Van de GVO-preventie respondenten is $95 \%$ van mening dat de schoolslag-checklist een goed kwaliteitsoordeel oplevert én dat het onderlinge kwaliteitsverschillen van programma's goed in beeld brengt. De deelnemers uit het onderwijs zijn hier terughoudender in: $85 \%$ van hen vindt dat de checklist een goed oordeel oplevert, terwijl $77 \%$ van mening is dat het de onderlinge kwaliteitsverschillen goed in beeld brengt. Desondanks is $48 \%$ van de respondenten van mening dat de checklist voor verbetering vatbaar is. Eén op de vijf respondenten ziet tevens graag een verbetering van de toelichting op de checklist wenselijk.

Het beoordelen van een project aan de hand van de schoolslag-checklist kostte de deelnemers gemiddeld 19 minuten. De professionals uit het preventieveld leken hier beduidend efficiënter in met een gemiddelde van 16,5 minuten tegen 21,1 minuten die onderwijsprofessionals rapporteren nodig te hebben gehad. 
Bij de preventiesector gaat de voorkeur uit naar een gebruikersvorm waarbij de oordelen vooraf door anderen gesteld worden (95\%). Deelnemers uit de sector onderwijs leken hier minder waarde aan te hechten (78\%). Wanneer de antwoorden van beide onderzoeksgroepen londerwijs en preventie) worden vergeleken, blijkt hier geen sprake te zijn van een significant verschil. Enkel de vraag over de plaatsing van de eindoordelen van de kwaliteitscriteria op internet leverde een significant verschillend resultaat op. De preventie-sector gaf de voorkeur aan bekendmaking van de oordelen via de website www.gezondopschool.nl gevolgd door de aanbieder van projecten terwijl de onderwijssector de voorkeur gaf aan www.kennisnet.nl gevolgd door de lokale instellingen. Overall bleek de Qui-database de minst relevant geachte databron voor het bekendmaken van kwaliteitsoordelen, gevolgd door de lokale instellingen.

\section{Resultaten betrouwbaarheid}

De resultaten van de betrouwbaarheidsanalyse gaven per kwaliteitscriterium een Cronbach's alpha variërend van 0,64 tot 0,92. Er waren geen items die een dusdanige negatieve invloed hadden op het geheel dat deze verwijderd dienden te worden.

Om een uitspraak te kunnen doen over het voorspellende vermogen van de schoolslag-checklist is een regressieanalyse uitgevoerd voor het gegeven rapportcijfer en de ingevulde checklist. Het voorspellende vermogen van de preventiecriteria varieert tussen de $45 \%$ en $77 \%$. Het voorspellend vermogen van de onderwijscriteria varieert tussen de $14 \%$ en $71 \%$.

Om een uitspraak te kunnen doen over het effect van de schoolslag-checklist op het rapportcijfer is een variantieanalyse uitgevoerd tussen het rapportcijfer gegeven vóór het invullen van de schoolslag-checklist en het rapportcijfer ná het invullen. Er is sprake van slechts een gering, niet significant, verschil tussen de twee rapportcijfers. Wel valt op dat het verschil tussen het eerste en tweede rapportcijfer bij de docenten minder groot is dan bij de deelnemers uit de preventie sector. Het lijkt er dus op dat de preventiedeskundigen zich meer hebben laten leiden door het oordeel van de checklist dan de onderwijsdeskundigen.

Aangezien noch het bruikbaarheidsonderzoek noch het betrouwbaarheidsonderzoek daartoe grote aanleiding gaven, is de schoolslag-checklist 1.2 vooralsnog niet gewijzigd. De items van checklist 1.2 zijn opgenomen in Tabel 3. 


\section{Tabel 3: Kwaliteitscriteria schoolslag-checklist}

\section{Overzicht van kwaliteitscriteria en items in de schoolslag-checklist $\odot 1.2$}

\section{Criterium Effectiviteit aangetoond (Preventie)}

1.1 Heeft het programma in het verleden de gewenste resultaten opgeleverd bij de doelgroep?

1.2 Heeft het programma in het verleden de gewenste resultaten opgeleverd op het gebied van procesverandering

1.3 Zijn de bewijzen op wetenschappelijk verantwoorde wijze verkregen?

\section{Criterium Planmatigheid (Preventie)}

2.1 Zijn de doelen theoretisch gefundeerd?

2.2 Zijn de korte termijn doelen duidelijk en specifiek?

2.3 Is de doelgroep duidelijk afgebakend?

2.4 Zijn de doelen gebaseerd op een degelijke analyse van het probleem?

2.5 Is de doelgroepkeuze gebaseerd op een degelijke analyse van het probleem?

2.6 Sluiten de programmastrategieën aan op de doelen?

2.7 Sluiten de programmastrategieën aan op de doelgroep?

2.8 Sluit de programma-inhoud aan op de doelen?

2.9 Sluit de programma-inhoud aan op de doelgroep?

2.10 Wordt in het programma gebruik gemaakt van effectief bewezen gedragsveranderingsprincipes (zoals actieve participatie, feedback, etc)?

2.11 Is er in het programma aandacht voor het aanleren of versterken van vaardigheden?

2.12 Is een vertegenwoordiging van de doelgroep betrokken geweest bij planning/ontwikkeling van het programma?

2.13 Zijn voorwaarden voor uitvoering gespecificeerd in een implementatieplan?

2.14 Is een vertegenwoordiging van de geplande uitvoerders betrokken geweest bij planning/ontwikkeling van het programma?

\section{Criterium Efficiëntie voor ondersteunende instelling (Preventie)}

3.1 Is de personele inzet (qua training, voorbereiding en begeleiding van uitvoering) voor de ondersteunende instelling redelijk voor dit programma?

3.2 Zijn de kosten (aanschaf materiaal, training medewerkers, etc.) voor de ondersteunende instelling redelijk voor dit programma?

3.3 Is de uitvoerbaarheid redelijk binnen de maximaal beschikbare tijd en financiële mogelijkheden?

\section{Criterium Efficiëntie voor school (Onderwijs)}

4.1 Is de personele inzet (qua voorbereiding en uitvoering) voor de school/docent redelijk voor dit programma?

4.2 Zijn de kosten (aanschaf materiaal, training, etc.) voor de school/docent redelijk voor dit programma?

4.3 Is het programma toepasbaar in meerdere leerjaren/kolommen binnen het onderwijs?

\section{Criterium Onderwijsgerichtheid (Onderwijs)}

5.1 Levert het programma een bijdrage aan één of meerdere onderwijsdoelen?

5.2 Bevordert het programma de sfeer in de klas of op school?

5.3 Is het programma inpasbaar binnen de gangbare methoden?

5.4 Geeft het programma ruimte voor persoonlijke invulling van lessen door docenten?

5.5 Is de beoordeling van docenten met ervaring met dit programma positief?

5.6 Is de beoordeling van leerlingen die met dit programma hebben gewerkt positief?

5.7 Is de vormgeving aantrekkelijk en geschikt voor de leerlingen?

5.8 Sluit het programma aan bij de wensen van de docenten?

5.9 Sluit het programma aan bij de belevingswereld van de leerlingen?

5.10 Is er binnen het programma ruimte voor differentiatie binnen klas/groep?

5.11 Richt het programma zich op verschillende thema's / onderwerpen?

5.12 Sluit het programma aan bij de regels van de school?

vervolg tabel 3 op pagina 140 
Tabel 3: Kwaliteitscriteria schoolslag-checklist (vervolg van pagina 139)

Overzicht van kwaliteitscriteria en items in de schoolslag-checklist $\odot 1.2$

6. Criterium Participatie (Preventie en Onderwijs)

6.1 Wordt actieve participatie van de doelgroep (doorgaans leerlingen) bij uitvoering van het programma aangemoedigd?

6.2 Worden ouders of andere personen, groepen of instellingen uit de gemeenschap actief betrokken bij het programma?

6.3 Worden ouders of andere personen, groepen of instellingen uit de gemeenschap passief betrokken bij het programma?

7. Criterium Aandacht voor de omgeving (Preventie en Onderwijs)

7.1 Is er binnen het programma aandacht voor een veilige en ondersteunende sociale omgeving met betrekking tot het thema?

7.2 Is er binnen het programma aandacht voor een veilige en ondersteunende fysieke omgeving met betrekking tot het thema?

8. Criterium Kwaliteit van ondersteunende instelling (Preventie en Onderwijs)

8.1 Is de ondersteuning tijdens de uitvoering adequaat?

8.2 Wordt het programma ondersteund door een betrouwbare organisatie?

9. Criterium Diversiteit (Preventie en Onderwijs)

9.1 Is het programma geschikt voor gebruik in multiculturele klassen?

9.2 Neemt het programma de doelgroep serieus (geen betuttelende toon)?

9.3 Draagt het programma bij aan vermindering van sociaal-economische gezondheidsverschillen (bijvoorbeeld door zich te richten op achterstandsgroepen of op problemen die juist bij deze groepen het meeste voorkomen)?

9.4 Respecteert het programma diversiteit in normen en waarden?

Voetnoot 1:

Antwoordmogelijkheden bij elk item: Ja (2 punten), Enigszins/vermoedelijk (1 punt), Nee (0 punten), Onbekend/niet van toepassing (0 punten). Per criterium worden de itemscores gesommeerd en vervolgens teruggebracht tot een eindoordeel Lijkt Goed, Lijkt Matig, Lijkt niet goed. Omdat het aantal items verschilt per criterium, verschilt per criterium ook de score die het eindoordeel bepaalt.

Voetnoot 2:

De complete schoolslag-checklist@ 1.2 is te downloaden via www.gezondeschool.nl.

\section{Discussie}

Binnen het beschreven onderzoek staat de evaluatie van de schoolslag-checklist centraal. De belangrijkste onderzoeksvraag die onderzocht is luidt: "Is de schoolslag-checklist een valide, betrouwbaar en bruikbaar instrument om de kwaliteit van preventieprogramma's voor het onderwijs te kunnen beoordelen.

Het meten van de kwaliteit van preventie programma's blijkt in de praktijk geen eenvoudige opgave. Kwaliteit is een veelzijdig begrip. Kwaliteit heeft betrekking op het stellen van eisen en het nagaan in hoeverre daaraan wordt voldaan. De definitie van kwaliteit in de context van het gebruik moet, in consensus met relevante betrokkenen, nader worden geoperationaliseerd met 
specifieke eisen, criteria en indicatoren (items). Dit is met name een grote uitdaging als het een kwaliteitskader betreft voor twee verschillende beroepsvelden, te weten preventie en onderwijs. In het beschreven onderzoek is de schoolslag-checklist als basis hiervoor gekozen (Peters, Leurs en anderen 2004). Bij de ontwikkeling van de eerste versie van de schoolslag-checklist waren relatief weinig mensen uit het onderwijs betrokken. Dit wreekte zich meteen bij de eerste kleinschalige toepassing, de pretest, waarbij docenten aangaven dat de checklist teveel criteria bevatte die irrelevant worden gevonden in het onderwijs. Dit resulteerde in aparte versies voor onderwijs en preventie, met een aantal criteria die in beide lijsten voorkomen. Uit het totale onderzoek blijkt, dat de oordelen op de overlappende criteria van de sector onderwijs en de sector preventie niet ver uit elkaar liggen. Dit bevestigt de keuze van opname van deze criteria in beide lijsten. Ook onderzoek naar de validiteit heeft geleid tot aanpassingen. Helaas waren bij het validiteitsonderzoek weer nauwelijks mensen uit het onderwijs betrokken. Waardoor harde uitspraken over de validiteit op basis van dit onderzoeksdeel niet mogelijk zijn. Uit verder onderzoek, waarin de deelnemers uit het onderwijs in de meerderheid waren, blijkt dat de checklist bruikbaar en waardevol wordt bevonden door beide velden, met vrijwel geen significante verschillen tussen die groepen. De herziene checklist lijkt dus op z'n minst aanvaardbaar voor professionals uit onderwijs en preventie, met de kanttekening dat een verbeterslag met name vanuit het onderwijsperspectief wenselijk lijkt.

In vergelijking met de gebruikerswaarde van de Preffi 2.0 lijkt de schoolslag checklist even prettig in het gebruik (Molleman, Peters en anderen 2003). Op de dimensies makkelijk / moeilijk, te kort/te lang en te compact / te uitgebreid lijkt de schoolslag-checklist het beter te doen dan de Preffi. De lager scorende dimensies waardevol / overbodig, compleet / onvolledig en duidelijk / onduidelijk geven een extra indicatie in welke richting de checklist te verbeteren is. We streven hierbij niet naar overall gelijkwaardigheid met de Preffi, daar de Preffi zich hoofdzakelijk focust op de planmatige ontwikkeling van preventieve interventies ter verhoging van de effectiviteit (Molleman and Hosman 2003). Dit is nu juist een van de kwaliteitscriteria waarin professionals uit het onderwijsveld minder zijn geïnteresseerd blijkens voorliggend onderzoek. De schoolslagchecklist is juist bedoeld als breed beoordelingsinstrument op het snijvlak van onderwijs en preventie ter versterking van planmatig en vraaggestuurd schoolgezondheidsbeleid.

De gerapporteerde toepassingstijd van de schoolslag-checklist hangt samen met de mate waarin beoordelaars al enige bekendheid en/of ervaring hebben met voorliggend project in combinatie met de hoeveelheid informatie die wordt aangeboden om de beoordeling op te baseren. We veronderstellen dat met name het eerste argument het verschil in beoordelingstijd tussen GVO-professionals en onderwijsprofessionals verklaart. Drie van de vier voorgelegde projecten zijn breed bekend in het GVO/preventieveld. Dit zijn de projecten "Lang Leve de Liefde", “Gezonde School en Genotmiddelen” en “De Rookvrije School”. Voor het project op het terrein 
van sociaal-emotionele ontwikkelen, "Leefstijl”, geldt dit minder. We verwachten dat naarmate een beoordelaar meer kennis heeft van, en ervaring met een project, een beoordeling gemakkelijk en sneller kan plaatsvinden. De beoordelaar hoeft dan minder nieuwe kennis over het project, ten behoeve van de beoordeling tot zich te nemen.

Onderzoeksdata wordt nader geanalyseerd ten behoeve van concretisering van het toepassingsprotocol van de checklist.

\section{Conclusie en aanbevelingen}

Wij concluderen dat de schoolslag-checklist een intern consistent en bruikbaar instrument is voor het bepalen van de kwaliteit van preventieprogramma's in, met en rondom het onderwijs. Om specifieke uitspraken te kunnen doen over de validiteit van de checklist is extra onderzoek wenselijk met voldoende deelname uit het preventie- én onderwijsveld.

Voor de toepassing van de schoolslag-checklist in de praktijk, doen we hierbij op basis van voorliggend onderzoek de volgende suggesties:

- Het is aan te raden de kwaliteitsoordelen van de preventieprogramma's te baseren op zowel de preventie-checklist als de onderwijs-checklist. Tezamen geven deze een volledig oordeel over de kwaliteit van het betreffende programma.

- De onderzoeksdeelnemers gaven de voorkeur aan kwaliteitsoordelen die door anderen zijn opgesteld. Dit overstijgt de reguliere lokale en regionale mogelijkheden. Het is aan het NIGZ en/of de landelijke werkgroep Gezonde School om hier invulling aan te geven.

- Uit ons onderzoek blijkt dat de twee sectoren een verschillende voorkeur hebben voor de rapportage van de kwaliteitsoordelen. We raden daarom plaatsing aan op zowel een onderwijssite (www.kennisnet.nl) als een site voor professionals (www.gezondeschool.nl).

- De inclusie van twee visies op kwaliteit is een belangrijke meerwaarde van de schoolslagchecklist ten opzichte van kwaliteitsbepalingen enkel op basis van planningsmethodieken als Preffi en Intervention Mapping. Hiermee bieden we een verfijning aan ten behoeve van de eclectische aanpak van schoolgezondheidsbeleid, passend binnen het nieuwe referentiekader Gezondheidsbevordering (De Vries 2004; Saan and De Haes 2004). We gaan ervan uit dat de schoolslag-checklist 1.2 reeds een bruikbaar kwaliteitsinstrument is met de potentie om planmatig en vraaggestuurd schoolgezondheidsbeleid te versterken. 


\section{Discussie}




\section{Discussie}

\section{Inleiding}

Dit proefschrift gaat over een studie naar de wijze waarop gezondheidsbevordering structureel wordt ingebed binnen het beleid en de praktijk van scholen voor voortgezet onderwijs. De hoofdvraagstelling is gericht op de belemmerende en bevorderende factoren voor de invoering van schoolgezondheidsbeleid middels de schoolslag-werkwijze.

Om hierin inzicht te verkrijgen is een onderzoek uitgevoerd bestaande uit drie delen. In het eerste deel is op basis van systematisch literatuuronderzoek een overzicht gegeven van effecten van gezondheidsbevorderende interventies op leerprestaties. In het tweede deel is onderzocht op welke manier GGD'en in Nederland scholen ondersteunen bij het opstellen en uitvoeren van structureel schoolgezondheidsbeleid. In het derde deel van het onderzoek is nader ingegaan op verschillende factoren die een rol spelen bij de structurele inbedding van gezondheidsbevordering in het beleid en de praktijk van scholen voor voortgezet onderwijs, op basis van de ervaringen in Zuid-Limburg. In dit proefschrift wordt onderscheid gemaakt tussen de lokale setting in Zuid-Limburg en de landelijke setting. In Zuid-Limburg spreken we over de schoolslag-werkwijze en schoolslag-adviseurs. Landelijk heeft men het over de Gezonde School Methode en schoolgezondheidsadviseurs. Wanneer wij in deze discussie spreken over de schoolslagwerkwijze en schoolslag-adviseurs is dit ook van toepassing voor de landelijke setting.

In dit afsluitende hoofdstuk worden aan de hand van de onderzoeksvraag en deelvragen de voornaamste bevindingen van het onderzoek beschreven en worden de gevonden resultaten in een bredere theoretische en toegepaste context geplaatst en aanbevelingen gegeven voor de praktijk. Daarnaast wordt kritisch gereflecteerd op het uitgevoerde onderzoek. Tot slot worden aanbevelingen voor verder onderzoek beschreven. 


\section{Beantwoording van de onderzoeksvragen}

In deze paragraaf worden de voornaamste resultaten van het onderzoek gepresenteerd aan de hand van de onderzoeksvragen.

\section{Deelvraag 1:}

Wat is bekend over de invloed van gezondheid op leerprestaties?

De theoretische onderbouwing van schoolgezondheidsbeleid is weliswaar groeiend, maar de empirische bewijsvoering over de gunstige effecten van schoolgezondheidsbeleid is nog erg minimaal (Bos en anderen, 2010; St.Leger \& Nutbeam, 1999; Stewart-Brown, 2001). Bekend is wel dat gezondheid positief gerelateerd is aan leerprestaties; ook is bekend dat schoolse interventies kunnen leiden tot verbetering van gezondheid. Direct bewijs voor een relatie tussen algemene schoolse interventies die zich niet richten op probleemgroepen of direct aan het leren gerelateerde problemen (ADHD, concentratie, etc.) en leerprestaties is echter spaarzaam. Dat blijkt opnieuw uit onze literatuur-review over de relatie tussen gezondheidsbevorderende activiteiten en leerprestaties (hoofdstuk 1). Wanneer we kunnen aantonen dat gezondheid de leerprestaties van leerlingen positief beïnvloedt draagt dit mogelijk positief bij aan het creëren van draagvlak voor de invoering van schoolgezondheidsbeleid. Leerprestaties vormen voor onderwijsprofessionals de belangrijkste drijfveer voor hun handelen. Jaarlijks worden scholen door de onderwijsinspectie beoordeeld op de leerprestaties van hun leerlingen. Daarnaast speelt ook het slagingspercentage van de eindejaarsleerlingen een grote rol bij de werving van nieuwe leerlingen (Inspectie van onderwijs, 2009). Wanneer we schoolgezondheidsbeleid een vaste plek willen geven in de structuur van het onderwijs lijkt het ervaren van een win-win situatie voor onderwijs- en gezondheidssector essentieel (Leurs, 2008). De review laat zien dat er inderdaad bewijs bestaat voor effecten van gezondheidsbevorderende activiteiten op de leerprestaties van leerlingen (hoofdstuk 1).

Deze conclusie wordt ook bevestigd in een onlangs uitgevoerde review van Suhrcke (2011). Suhrcke stelt in de review dat er wel bewijs is voor correlatie, maar dat bewijs voor een causale relatie tussen leerprestaties en gezondheid of andersom ontbreekt (Suhrcke, 2011).

\section{Deelvraag 2:}

Op welke manier ondersteunen GGD'en in Nederland scholen bij het opstellen en uitvoeren van structureel schoolgezondheidsbeleid?

Enkel empirische onderbouwing voor positieve effecten van gezondheidsbevordering op leerprestaties is niet voldoende om scholen enthousiast te maken voor de invoering van 
schoolgezondheidsbeleid binnen het voortgezet onderwijs. Er zijn tal van andere factoren van invloed op de daadwerkelijke implementatie van schoolgezondheidsbeleid binnen scholen voor voortgezet onderwijs (hoofdstuk 2, 3). Uit ons onderzoek blijkt dat een meerderheid van de ondervraagde GGD'en aangeeft bij scholen te investeren in het tot stand brengen van schoolgezondheidsbeleid. Activiteiten die worden uitgevoerd zijn onder andere het creëren van draagvlak voor schoolgezondheidsbeleid, het in kaart brengen van de gezondheidssituatie van de leerlingen, het stellen van prioriteiten, het bepalen van strategieën voor de aanpak van de prioriteiten en het uitvoeren en evalueren van activiteiten. GGD'en volgen het stappenplan, maar ze ervaren met name het creëren van draagvlak bij scholen als lastig (hoofdstuk 2). Draagvlak zou versterkt kunnen worden door de invoering van een één-loket functie, door een duidelijke visie uit te dragen ten aanzien van schoolgezondheidsbeleid, door de dialoog met scholen aan te gaan en de omslag te maken van aanbodgericht werken naar vraaggericht werken, wat opgenomen wordt in de schoolwerkplannen. De verwachting is dat door deze omslag het uiteindelijk minder tijd kost om de gezondheid van leerlingen te bevorderen en dat er meer effect wordt behaald dan wanneer scholen ieder jaar opnieuw losse activiteiten organiseren.

Ook is gevraagd naar de factoren die GGD'en ervaren als belemmerend dan wel bevorderend voor de implementatie van schoolgezondheidsbeleid (hoofdstuk 2). De ervaringen die GGD'en hebben met de invoering van schoolgezondheidsbeleid zijn wisselend. Gebrek aan tijd, gebrek aan draagvlak en het ontbreken van een taakopvatting over gezondheid worden door de GGD ervaren als de belangrijkste belemmerende factoren binnen het onderwijs.

Deze resultaten komen overeen met de resultaten van eerder uitgevoerd onderzoek door Deschesnes en anderen (2010) naar factoren die het adoptieproces van structureel schoolgezondheidsbeleid in Quebec, Canada, beïnvloeden. Gebrek aan tijd en draagvlak bij scholen worden ook daar als belangrijke belemmerende factoren benoemd (Deschesnes, Trudeau \& Kébé, 2010). Het ontbreken van een taakopvatting voor het onderwijs bleek geen belemmerende factor voor de invoering van schoolgezondheidsbeleid, wellicht omdat dit in Canada een gezamenlijk initiatief is van de ministeries verantwoordelijk voor onderwijs en gezondheid (Deschesnes, Couturier, Laberge \& Campeau, 2010).

\section{Deelvraag 3:}

In welke mate is de schoolslag-werkwijze structureel ingebed in het beleid van de scholen voor voortgezet onderwijs in regio Zuid-Limburg?

Om beter inzicht te krijgen in de wijze waarop GGD'en scholen zouden kunnen ondersteunen bij de invoering van schoolgezondheidsbeleid en wat de effecten van dergelijke ondersteuning zijn, is in het derde deel van dit proefschrift (hoofdstuk $3,4,5$ ) de implementatie van schoolgezond- 
heidsbeleid bij scholen voor voortgezet onderwijs in Zuid-Limburg nader onderzocht. In ZuidLimburg is een werkwijze ontwikkeld voor structureel schoolgezondheidsbeleid, de schoolslagwerkwijze. Sinds de ontwikkeling van de schoolslag-werkwijze in 2002 is in Zuid-Limburg veel ervaring opgedaan met de invoering van schoolgezondheidsbeleid. Bij aanvang van het implementatieproces van de schoolslag-werkwijze zijn alle scholen benaderd door een schoolslagadviseur. Van de 25 benaderde scholen hebben zeven scholen ervoor gekozen niet aan het onderzoek deel te nemen. Op basis van het uitgevoerde onderzoek blijkt dat vijftien van de achttien ondervraagde scholen voor voortgezet onderwijs aandacht geven aan gezondheid en veiligheid. (hoofdstuk 3).

Scholen zijn bevraagd over de belemmerende en bevorderende factoren voor de invoering van schoolgezondheidsbeleid (hoofdstuk 3). Scholen benadrukken dat gezondheid binnen het onderwijs geen prioriteit heeft: het is niet als taak opgenomen in de kerndoelen. De betrokkenheid vanuit het management wordt als minimaal ervaren. Scholen hebben geen uren begroot voor gezondheid, de ureninvestering voor schoolgezondheidsbeleid (in de vorm van de schoolslagwerkwijzel komt bovenop de al hoge taakbelasting. Daarnaast geven de respondenten aan de schoolslag-werkwijze te ervaren als een keurslijf waarin weinig ruimte is voor de wensen en mogelijkheden van de school.

De conclusie dat de werkwijze te weinig aansluit bij de mogelijkheden van het onderwijs wordt onderschreven door vergelijkbaar onderzoek in Quebec, Canada. Deschesnes en collega's (2010) concluderen op basis van documentenanalyse en interviews dat de werkwijze voor schoolgezondheidsbeleid te theoretisch is en te weinig rekening houdt met de mogelijkheden van het onderwijs (Deschesnes, Couturier, Laberge \& Campeau, 2010).

\section{Deelvraag 4:}

Is de advisering van de schoolslag-adviseur van invloed op de invoering van structureel schoolgezondheidsbeleid bij scholen voor voortgezet onderwijs in regio Zuid-Limburg?

Bij de ontwikkeling van de schoolslag-werkwijze is nagedacht over de manier waarop schoolgezondheidsbeleid, binnen de beperkte mogelijkheden van het onderwijs, verbeterd kan worden en hoe dit een plek zou moeten krijgen binnen de bestaande structuren (Leurs, 2008). Als antwoord hierop is de functie van schoolslag-adviseur geïntroduceerd. Dit is een één-loket functie voor het onderwijs, uitgevoerd door een preventieprofessional die namens alle samenwerkingspartners op het terrein van preventie de school ondersteunt bij de invoering van schoolgezondheidsbeleid. Later is deze functie ook opgenomen in de landelijke Handleiding Gezonde School. 
In hoofdstuk 4 is de rol van de schoolslag-adviseur bij de structurele invoering van schoolgezondheidsbeleid in het voortgezet onderwijs in de regio Zuid-Limburg geëvalueerd. Er is een relatie gevonden tussen de tevredenheid over de begeleiding en de uitvoering van een aantal specifieke onderdelen van het stappenplan. Op basis van het uitgevoerde onderzoek kunnen echter geen uitspraken worden gedaan over de causaliteit Het lijkt aannemelijk dat de rol van de schoolslag-adviseur bepalend is voor de implementatie van de schoolslag-werkwijze. Omdat bij schoolgezondheidsbeleid de link tussen onderwijs en preventieveld van belang is. Het is de taak van de schoolslag-adviseur om juist deze verbinding in stand te brengen en te houden (hoofdstuk 4).

\section{Deelvraag 5:}

Hoe kan de advisering door de schoolslag-adviseur bijdragen aan de invoering van structureel schoolgezondheidsbeleid bij scholen voor voortgezet onderwijs in regio Zuid-Limburg?

Om deze vraag te kunnen beantwoorden is de school in Zuid-Limburg die het verst was met de invoering van schoolgezondheidsbeleid in een 'extreme cases-design' vergeleken met de school die het minst ver was met de invoering van schoolgezondheidsbeleid. Voorzichtig concluderen we dat een schoolslag-adviseur die zowel aandacht geeft aan de implementatie van het schoolslagstappenplan als aan de organisatorische aspecten (zoals verandermanagement, projectmanagement en samenwerking), positief bijdraagt aan de succesvolle implementatie van schoolgezondheidsbeleid (hoofdstuk 5). Een adviseur die zich enkel richt op de implementatie van het schoolslag-stappenplan lijkt eerder belemmerend te werken op de implementatie van schoolgezondheidsbeleid. De vaardigheden die nodig zijn om de implementatie van schoolgezondheidsbeleid als een organisatieverandering te benaderen zijn over het algemeen niet aangeleerd in primaire opleidingen voor medewerkers gezondheidsbevordering, maar lijken wel essentieel voor succes in het begeleiden van scholen bij de invoering van schoolgezondheidsbeleid.

Net als de resultaten van het uitgevoerde onderzoek blijkt ook uit recent Canadees onderzoek dat de organisatorische context Igeoperationaliseerd als ondermeer de prioriteit die scholen geven aan schoolgezondheidsbeleid, aanwezigheid van leiders binnen de school en ervaren contextuele barrières binnen de school) een cruciale rol speelt bij de adoptie van werkwijzen voor schoolgezondheidsbeleid (Deschesnes, Trudeau \& Kébé, 2010).

\section{Deelvraag 6:}

Kan de schoolslag-checklist dienen als hulpmiddel om de kwaliteit van schoolse interventies te bepalen en de keuze uit het preventieaanbod eenvoudiger te maken? 
Om als schoolslag-adviseur een school goed te kunnen adviseren op het terrein van schoolgezondheidsbeleid blijft naast procesbegeleiding ook de inhoudelijke kennis over preventieprogramma's van groot belang. Om deze rol goed te kunnen vervullen is binnen de schoolslag-werkwijze een inventarisatie gemaakt van beschikbare interventies voor de regio, geordend naar thema. Om een goede combinatie te kunnen maken van de wens van de school en de kwaliteiten van een interventie is de schoolslag-checklist ontwikkeld. Dit is een beoordelingsinstrument voor interventies, bedoeld om scholen op maat te adviseren. Uit het onderzoek blijkt dat de schoolslag-checklist bruikbaar en betrouwbaar is voor de selectie van schoolse interventies die aansluiten op de behoefte van de school (hoofdstuk 6). Toetsingscriteria van de schoolslag-checklist zijn samen met criteria van andere instrumenten door CGL opgenomen in het toetsingsinstrument voor schoolse interventies in de i-database (Brug, van Dale, Lanting, Kremers, Veenhof, Leurs, van Yperen \& Kok, 2010). Daarnaast is de schoolslag-checklist internationaal als basis gebruikt voor het toetsingsinstrument binnen het HEPS-project, een project gericht op het verminderen van het aantal kinderen met overgewicht in Europa (Dadaczynski, Paulus, de Vries, de Ruiter \& Buijs, 2010)

\section{Hoofd onderzoeksvraag:}

\section{Wat zijn de bevorderende en belemmerende factoren voor de invoering van schoolgezondheidsbeleid middels de schoolslag-werkwijze?}

Wanneer we de huidige mate van implementatie toetsen aan de definitie, dat er pas sprake is van structureel schoolgezondheidsbeleid wanneer samenhangend beleid wordt gemaakt op de thema's schoolgezondheidsbeleid, fysieke omgeving van de school, sociale omgeving van de school, school / community relaties, ontwikkeling van persoonlijke gezondheidsvaardigheden en schoolgezondheidszorg binnen een planmatige structuur, dan moeten we concluderen dat er nog lang niet in alle gevallen sprake is van structurele inbedding. Steeds meer GGD'en en scholen besteden op enige manier structureel aandacht aan gezondheid; de wijze waarop dit gebeurt verschilt sterk. Op basis van het uitgevoerde onderzoek kunnen de volgende factoren worden benoemd die het implementatieproces van schoolgezondheidsbeleid kunnen beïnvloeden:

- Pleitbezorging gericht op de meerwaarde van gezondheid voor het behalen van de doelen van het onderwijs in plaats van met name in te steken op het belang van gezondheid.

- Creëren van draagvlak voor schoolgezondheidsbeleid door meer aansluiting te zoeken bij de context van het onderwijs: wat is hun taakstelling, waar worden ze op afgerekend en hoe kan schoolgezondheidsbeleid hieraan een bijdrage leveren?

- Versterken van het gevoel van probleemeigenaar bij de scholen door het formuleren van een gezamenlijke visie voor schoolgezondheidsbeleid die aansluit bij de wensen en mogelijkheden 
van het onderwijs en daaraan gekoppeld een duidelijke verdeling van taken en verantwoordelijkheden.

- Versterken van de participatie van het onderwijs bij de implementatie van schoolgezondheidsbeleid, niet alleen bij de implementatie op schoolniveau maar ook bij de (door) ontwikkeling van de werkwijze.

- Verbreding van de expertise van de schoolslag-adviseur van enkel preventiekennis naar vaardigheden in verandermanagement en kennis van het onderwijssysteem.

- De begeleiding door de schoolslag-adviseur beter laten aansluiten bij de wensen en mogelijkheden van de school. Zo kan de schoolslag-adviseur bijvoorbeeld realistischere doelen formuleren die aansluiten bij de wensen en mogelijkheden van het onderwijs.

- De strakke structuur van het schoolslag-stappenplan loslaten. Het stappenplan hanteren als hulpmiddel en niet als doel op zich.

- Deinvoering vanschoolgezondheidsbeleid op schoolniveau benaderen als een veranderproces binnen een organisatie door meer aandacht te hebben voor procesbegeleiding.

- Meer investeren in training en coaching van zowel onderwijs als preventie- professionals. Voor het onderwijs dient de training gericht te zijn op de meerwaarde van gezondheid voor het behalen van de doelen van het onderwijs. Voor de schoolslag-adviseur dient de training gericht te zijn op de organisatie van het onderwijs en het vinden van aanknopingspunten voor gezondheid.

\section{Aanbevelingen voor de praktijk}

Het beschreven onderzoek leert ons dat veel factoren het implementatieproces van schoolgezondheidsbeleid beïnvloeden. In deze paragraaf worden de belangrijkste factoren zoals hierboven benoemd verder uitgewerkt.

\section{Pleitbezorging door europese, landelijke en lokale overheden voor schoolgezondheidsbeleid}

Zowel scholen als GGD'en benoemen het ontbreken van een wettelijk kader als een belangrijke belemmerende factor voor de implementatie van schoolgezondheidsbeleid (hoofdstuk 2, 3). Een duidelijke taakstelling gericht op het bevorderen van de gezondheid van leerlingen in het onderwijs ontbreekt. De verantwoordelijkheden voor schoolgezondheidsbeleid vallen in een grijs gebied tussen het ministerie van Volksgezondheid, Welzijn en Sport (VWS) en het ministerie van Onderwijs, Cultuur en Wetenschap (OC\&W). De literatuur benadrukt eveneens de invloed van wettelijke kaders bij de implementatie van innovaties. Zowel Shediac-Rizkallah en Bone (1998) als Fleuren, Wiefferink en Paulussen (2004) beschrijven de rol van de sociaal-politieke omgeving. Deze externe factoren zijn bepalend voor de context waarbinnen de eindgebruiker 
keuzes maakt om iets wel of niet te doen. Echter hoe bepalend het wettelijke kader ook is, deze factor is nauwelijks te beïnvloeden vanuit de lokale overheden, dus zijn er voor GGD- of onderwijsprofessionals geen praktische aanbevelingen aan te ontlenen.

De resultaten van het onderzoek bevestigen de zwakke positie van gezondheid in het onderwijs. Ook in de literatuur wordt benadrukt dat de gezondheidssector en de onderwijssector meer naar elkaar toe moeten schuiven (Deschesnes, Trudeau \& Kébé, 2010; St Leger \& Nutbeam, 2000; Paulus, 2005). Versterking van de positie van gezondheid in het onderwijs vraagt om duidelijke pleitbezorging voor schoolgezondheidsbeleid. Het belang van pleitbezorging wordt onderschreven door bijvoorbeeld Altman en anderen (1994); Deschesnes en anderen (2003); Deschesnes en anderen (2010). Op landelijk niveau heeft het ministerie van VWS een belangrijke rol in de pleitbezorging neergelegd bij Centrum Gezond Leven. Zij hebben als taak om effectieve werkwijzen te bundelen. Daarnaast hebben zij een belangrijke rol in het uitdragen van het belang van schoolgezondheidsbeleid, althans, zolang schoolgezondheidsbeleid geen wettelijk kader kent. Vanuit hun centrale positie kunnen zij fungeren als ambassadeur, om zowel de onderwijsinspectie als de VO-raad te overtuigen van de meerwaarde van aandacht voor gezondheid in het onderwijs. Ondanks het ontbreken van een wettelijk kader kan de onderwijsinspectie speerpunten benoemen ter verbetering van het onderwijs. Ze zouden hierin kunnen kiezen voor een speerpunt gericht op aandacht voor gezondheid in het onderwijs. Door hun toetsende rol richting scholen kunnen ze direct invloed uitoefenen op de beleidsvoering van scholen; het CGL zou dit kunnen bepleiten. De VO-raad stelt kaders voor de praktische vertaling van de onderwijskerndoelen en de kwaliteitsagenda op lokaal niveau. Wanneer het belang van schoolgezondheidsbeleid wordt verbonden met de vertaling van de kerndoelen zal dit schoolbesturen stimuleren om schoolgezondheidsbeleid binnen hun scholen op de agenda te zetten.

Op lokaal niveau moet de GGD samen met andere preventieprofessionals de rol van pleitbezorging vervullen richting gemeenten, zowel bij de verantwoordelijke wethouder en ambtenaar voor gezondheid als die van onderwijs. Gemeenten die het belang van schoolgezondheidsbeleid benoemen in hun lokale nota legitimeren hiermee de tijdsinvestering van preventieprofessionals voor de implementatie van schoolgezondheidsbeleid op schoolniveau.

Ook op internationaal niveau wordt steeds meer informatie verzameld waarmee de onderwijssector overtuigd kan worden van de meerwaarde van schoolgezondheidsbeleid. Onlangs is in opdracht van de WHO een review uitgevoerd over de relatie tussen gezondheidsgerelateerd gedrag/risicofactoren en leerprestaties (Suhrcke 2011). De resultaten van dit soort reviews kunnen ook op landelijk en lokaal niveau een positieve bijdrage leveren aan het vergroten van het draagvlak vanuit overheden. 
Zo is bijvoorbeeld binnen het HEPS-project een handleiding opgesteld voor preventieprofessionals om te pleiten voor acties gericht op het verminderen van het aantal kinderen met overgewicht in Europa (Bada en anderen, 2009). In deze handleiding staat een stappenplan gericht op pleitbezorging voor de aanpak van overgewicht. Steeds meer preventie-organisaties erkennen de noodzaak van hun rol als pleitbezorger en dragen deze uit. Dit onderstreept de aanbeveling om ook in Nederland breder in te zetten op pleitbezorging gericht op de meerwaarde van schoolgezondheidsbeleid voor het onderwijs. Door op alle niveaus gezondheid op de agenda te zetten wordt zowel top-down als bottom-up de meerwaarde van schoolgezondheidsbeleid benadrukt.

Het uitgevoerde onderzoek leert ons dat onderwijsprofessionals geen prioriteit geven aan gezondheid, omdat het hun primaire, op educatieve ontplooiing gerichte, doelstellingen niet direct lijkt te dienen. Om die reden is het belangrijk de pleitbezorging niet alleen in te zetten om het belang van gezondheid aan te tonen, maar om zichtbaar te maken hoe gezondheid kan bijdragen aan de doelen van het onderwijs. Dat was dan ook de reden voor het uitvoeren van de review die in hoofdstuk 2 is gerapporteerd: gezondheids-bevorderende interventies kunnen ook leerprestaties verbeteren.

\section{Stevig draagvlak op schoolniveau is essentieel voor invoering schoolgezondheidsbeleid}

Om op schoolniveau draagvlak te kunnen creëren voor schoolgezondheidsbeleid is het van belang de meerwaarde van schoolgezondheidsbeleid voor het onderwijs inzichtelijk te maken. Kennis over de effectiviteit van de werkwijze kan het proces van overtuiging positief beinvloeden. Echter, de effectiviteit van de schoolslag-werkwijze of van schoolgezondheidsbeleid is nog niet aangetoond (Bos en anderen, 2010; Mukoma \& Flisher, 2004; St.Leger, 2004; Stewart-Brown, 2001). Wel bevestigen cross-sectionele onderzoeken een relatie tussen de gezondheid van leerlingen en hun leerprestaties (Bos en anderen, 2010; Stewart-Brown, 2001). Ook zijn er legio onderzoeken bekend over het effect van schoolse interventie zoals Lang Leve de Liefde en De Gezonde School en Genotmiddelen en direct schoolgerelateerde aspecten als concentratieproblemen en pesten. In hoofdstuk 1 is een literatuuronderzoek beschreven naar de relatie tussen gezondheidsbevorderende interventies en leerprestaties. Gezondheidsbevorderende interventies (met name gericht op fysieke activiteit en op voeding) blijken op onderdelen effectief leerprestaties van jongeren te kunnen verhogen. Het is van belang deze onderzoeksresultaten in te zetten om de onderwijssector te overtuigen van de meerwaarde voor schoolgezondheidsbeleid.

Draagvlak speelt een grote rol bij implementatieprocessen. Op basis van de resultaten kan gesteld worden dat het belang van aandacht voor gezondheid door zowel zorgcoördinatoren en 
docenten als door het management wordt ingezien, echter dit belang wordt niet vertaald naar actie. Daarbij geven de respondenten aan dat het draagvlak voor schoolgezondheidsbeleid op directieniveau minimaal is.

De literatuur onderschrijft het belang van draagvlak bij de implementatie van een innovatie. Rogers (1995) benadrukt dat draagvlak niet vanzelf ontstaat. lemand zal pas openstaan voor de innovatie wanneer hij/zij het nut erkent, wanneer de innovatie toepasbaar is binnen de eigen context, wanneer de complexiteit te behappen is, wanneer er uitprobeermogelijkheden zijn en wanneer de effecten observeerbaar zijn.

Daarnaast is investeren in een relatie met de eindgebruiker, in dit geval de school, essentieel. De eindgebruiker moet gevoel krijgen bij de innovatie en voordelen zien voor zijn eigen handelen. Om mensen te kunnen overtuigen van de noodzaak van schoolgezondheidsbeleid en draagvlak te bouwen is het van belang te investeren in het informeren van de eindgebruiker, het enthousiasmeren van de eindgebruiker, waardoor deze uiteindelijk in beweging komt om de innovatie over te nemen (Moulding en anderen 1999; Prochaska \& DiClemente, 1983). Voor de implementatie van schoolgezondheidsbeleid is draagvlak op schoolniveau onmisbaar. De school is uiteindelijk de eindgebruiker die de beslissing neemt om wel of niet te investeren in schoolgezondheidsbeleid. Ons onderzoek leert dat voor het creëren van draagvlak binnen de school meer aansluiting gezocht moet worden met de context van het onderwijs. Wat is hun taakstelling, waar worden ze op afgerekend en hoe kan schoolgezondheidsbeleid hieraan een bijdrage leveren? Dit vraagt echter andere kennis van de schoolslag-adviseur dan alleen op het gebied van preventie en gezondheidsbevordering. Het verdient aanbeveling om de kennis over gezondheidsbevordering uit te breiden met kennis op het terrein van verandermanagement en het onderwijssysteem. Door als gelijkwaardige gesprekspartner de dialoog aan te gaan met het onderwijs en aansluiting te vinden met de kaders die voor het onderwijs leidend zijn, kan het proces van draagvlak creëren soepeler verlopen. Op landelijk niveau is het van belang dat Centrum Gezond Leven naast de ondersteuning bij de implementatie van de Gezonde School Methode ook aandacht heeft voor kennisoverdracht op het gebied van het onderwijssysteem en de mogelijkheden voor aansluiting met schoolgezondheidsbeleid.

\section{Disbalans in probleemeigenaarschap tussen bereidwillige scholen en de GGD}

De resultaten van het onderzoek tonen aan dat scholen zichzelf niet als probleemeigenaar zien. De visie op schoolgezondheidsbeleid wordt nog niet door iedereen gedragen. Scholen geven aan de schoolslag-werkwijze te zien als een extern project waarin ze participeren, maar waar ze zelf geen directeverantwoordelijkheid voor dragen. Naar hun mening wordt dezeverantwoordelijkheid gedragen door deschoolslag-adviseurs, vertegenwoordigers van de betrokken preventiepartners. 
Dit wordt niet onderschreven door de schoolslag-adviseurs, die liever een gedeelde verantwoordelijkheid zouden zien (hoofdstuk 3, 4, 5).

Naast het DISC-model (Leurs,2008) onderschrijven ook andere modellen het belang van een duidelijke probleemeigenaar. Volgens Bracht en Kingsbury (1990) en Flynn (1995) draagt "ownership" bij aan het verhogen van de mogelijkheden en het bevorderen van de verankering van de innovatie. Ook Stewart (2008) wijst op het belang van "ownership". Daarnaast benadrukt hij dat het voor succesvolle implementatie noodzakelijk is dat de gebruikers een "ik kan het" houding aannemen ten opzichte van de innovatie.

Tot nu toe ligt de rol van probleemeigenaar nog vooral bij de GGD en nog te weinig bij de school. Idealiter zouden zowel de GGD als de school de rol van probleemeigenaar moeten dragen. Deze gezamenlijke verantwoordelijkheid betekent wel dat goede afstemming van taken en verantwoordelijkheden essentieel is. Het gevoel van probleemeigenaarschap bij de scholen zou mogelijk versterkt kunnen worden door het inzichtelijk maken van de meerwaarde van de implementatie van schoolgezondheidsbeleid voor het behalen van de onderwijsdoelen. Daarnaast is het van belang dat de visie op schoolgezondheidsbeleid aansluit bij zowel de visie van de preventiepartners als de visie van het onderwijs.

\section{Participatie van de onderwijssector bij invoering schoolgezondheidsbeleid}

Binnen de schoolslag-werkwijze is een belangrijke rol weggelegd voor het onderwijs. Hierbij gaat het zowel om participatie van de onderwijssector als geheel als participatie van docenten en leerlingen. De onderwijssector werkt, samen met de schoolslag-adviseur, aan het organiseren van de verschillende stappen van het schoolslag-stappenplan en uiteindelijk aan de inbedding van schoolgezondheidsbeleid in het huidige schoolsysteem. Het lijkt erop dat de werkwijze nog teveel vóór de school is bedacht in plaats van dóór de school (hoofdstuk 3). De vraag is dan ook of de schoolslag-werkwijze past bij de identiteit van de scholen of teveel is ontwikkeld met een gezondheidsbril. Op basis van de resultaten moet geconcludeerd worden dat de scholen de werkwijze niet massaal omarmd hebben. Ze zijn blij met de begeleiding van de schoolslagadviseur, maar zien de invoering van het schoolslag-stappenplan eerder als een tijdrovend beleidsinstrument dan als een praktisch hulpmiddel dat hun problemen oplost. Het verdient aanbeveling om de participatie van het onderwijs te verhogen bij de (door)ontwikkeling van de schoolslag-werkwijze. Stewart (2008) benadrukt dat het van belang is deze participatie niet te beperken tot meedenken en adviseren, maar het onderwijs een bepalende rol te geven bij beslissingen over de implementatie en de (doorlontwikkeling van de schoolslag-werkwijze, niet alleen op schoolniveau maar ook op het niveau van de lokale projectorganisatie. 
Ook op internationaal niveau is het belang van participatie erkend. Bij de ontwikkeling van het HEPS-project wordt gewerkt vanuit nationale instituten en ministeries. Dit is vergelijkbaar met de organisatie in Nederland. Het onderwijs is niet actief betrokken bij de ontwikkeling van de werkwijze. Wel wordt gewerkt met een adviesraad met vertegenwoordigers.

Barnekow en anderen (2006) gaan echter nog een stap verder en benoemen participatie en nog specifieker leerling-participatie als belangrijkste element van schoolgezondheidsbeleid. De resultaten laten zien dat participatie in de huidige visie van schoolgezondheidsbeleid onmisbaar is. Binnen de huidige ontwikkelingen is participatie zowel op het niveau van de onderwijssector als op het niveau van individuele docenten en leerlingen echter nog onderbelicht. Het verdient dan ook aanbeveling om de onderwijssector een krachtigere rol te geven zowel bij de ontwikkeling als uitvoering van schoolgezondheidsbeleid.

\section{Flexibilisering van schoolslag-stappenplan bij invoering schoolgezondheidsbeleid}

Het schoolslag-stappenplan is ontwikkeld om scholen te kunnen begeleiden bij de invoering van schoolgezondheidsbeleid. De resultaten van het onderzoek laten zien dat de eerste stappen van het stappenplan wel worden toegepast, maar naarmate de stappen beleidsmatiger worden wordt de toepassing in de praktijk zwakker (hoofdstuk 3). In de case studie in Zuid-Limburg tonen de resultaten een gebrek aan aanpasbaarheid. De schoolslag-adviseurs worstelen met het gebruik van het schoolslag-stappenplan. Vanuit de projectorganisatie krijgen ze de opdracht om de verschillende stappen te doorlopen, terwijl de school vaak met een concrete hulpvraag zit die ze op korte termijn opgelost wil zien. Op dit moment voelen de schoolslag-adviseurs nog weinig ruimte om flexibel in te kunnen spelen op concrete hulpvragen uit de school.

Ook door scholen wordt het gebrek aan flexibele begeleiding ervaren als een probleem. Respondenten geven aan dat bij de ontwikkeling van de schoolslag-werkwijze te weinig rekening is gehouden met het aanpassingsvermogen van de school (hoofdstuk 3). Wanneer een school een specifieke hulpvraag heeft past deze specifieke activiteit niet binnen de structurele aanpak van de schoolslag-werkwijze. De werkwijze is als stappenplan ontwikkeld. Dit stappenplan is bepalend voor de procesbegeleiding van de schoolslag-adviseur. De school dient te starten met de inventarisatie van de zorgbehoefte en te eindigen met evalueren en verankeren.

De respondenten in Zuid-Limburg benadrukken dat de schoolslag-adviseur redelijk star vasthoudt aan het schoolslag-stappenplan waardoor het moeilijk wordt de werkwijze aan de wensen en beperkte mogelijkheden van de school aan te passen (hoofdstuk 3). Als de schoolslagadviseur flexibeler om zou gaan met het schoolslag-stappenplan zou dat de scholen meer mogelijkheden bieden. 
Deze conclusie is in lijn met het concept van aanpasbaarheid uit de innovatietheorie van Rogers (1995). Rogers (1995) benadrukt in zijn model het belang van het aanpassen en bijstellen van een innovatie afhankelijk van de context. Dit wordt onderschreven door Paulussen en anderen (2008). Zij maken onderscheid in drie niveau's, het macro-, meso- en micro-niveau. Het macroniveau richt zich op de externe aanbieder. Op macro-niveau wordt de innovatie beschreven zoals deze is bedacht. Op het meso-niveau gaat de intermediaire gebruiker met de innovatiebeschrijving aan de slag. De innovatie wordt geïmplementeerd. Mogelijk worden in deze wisseling al wijzigingen aangebracht in de oorspronkelijke plannen om het werkbaar te maken. Op het micro-niveau gaat de eindgebruikers daadwerkelijk met de innovatie aan de slag, maar doet dit vaak wel op hun eigen manier en met hun eigen aanpassingen. Pas in deze laatste stap wordt de uiteindelijke vorm van de innovatie zichtbaar. Volgens Paulussen is een belangrijk kenmerk van implementatie van sociale innovaties, zoals bijvoorbeeld de implementatie van schoolgezondheidsbeleid, dat de interventie zelden wordt toegepast zoals de bedenker dit heeft bedacht. In een ideale situatie is vooraf al rekening gehouden met het aanpassingsvermogen door de eindgebruiker (Paulussen, Wiefferink \& Mesters, 2008; Rogers, 1995).

Het geschetste probleem vraagt om een flexibele aanpak van het schoolslag-stappenplan. Deze situatie komt overeen met de toepassing van de regulatieve beleidscyclus. Deze bestaat uit vier opeenvolgende stappen: definiëren van een maatschappelijk relevant probleem, beleidsformulering, beleidsuitvoering en beleidsevaluatie. Zelden worden deze vier stappen in de beleidspraktijk in deze volgorde doorlopen. Het beleidsproces verloopt meestal veel chaotischer, omdat verschillende belangen tegen elkaar moeten worden afgewogen en er tijdens het proces allerlei onverwachte aspecten naar voren kunnen komen waarmee rekening gehouden moet worden. De beleidscyclus wordt dus als het ware via een hink-stap-sprong lijn uitgezet. Dus van stap een naar stap twee en weer terug, om vervolgens weer door te gaan met stap drie. Binnen dit proces is het stappenplan vooral bedoeld om het proces te structureren (Jansen, 2007).

Het lijkt voor de hand te liggen om ook bij de toepassing van het schoolslag-stappenplan de strakke structuur los te laten en te kiezen voor een interactief proces waarbij gesprongen kan worden tussen stappen. Het stappenplan zou meer gezien moeten worden als een een richtlijn voor procesbegeleiding dan als een leidend instrument. Het doorlopen van het stappenplan van voren naar achteren dient geen doel op zich te zijn. Het dient als hulpmiddel om een school te begeleiden bij het implementeren van schoolgezondheidsbeleid. De behoefte van de school bepaalt hoe de advisering zal verlopen. Wanneer een school bijvoorbeeld een actueel probleem heeft op het gebied van pesten, dient de schoolslag-adviseur de ruimte te hebben om meteen te focussen op dit specifieke probleem, zonder eerst breed de gezondheidssituatie van de school in kaart te hoeven brengen en prioriteiten te stellen. 
Op landelijk niveau is rekening gehouden met het aanpassingsvermogen van de gebruiker, in dit geval de GGD'en. Centrum Gezond Leven richt zich met name op het begeleiden van preventieprofessionals bij de implementatie van de Gezonde School Methode op regioniveau. Hiertoe ontwikkelen ze hulpmiddelen. Ook bij deze hulpmiddelen is het van belang dat ze aangepast kunnen worden aan de wensen en mogelijkheden van de verschillende regio's. Bij de ontwikkeling van de handleiding Gezonde School is hiermee rekening gehouden. Deze wordt gepresenteerd als een handreiking om vorm te geven aan schoolgezondheidsbeleid en niet als een blauwdruk (De Jongh en anderen, 2010).

\section{De schoolslag-adviseur als procesbegeleider}

Zoals al aangegeven bij de paragraaf over het belang van draagvlak vraagt de implementatie van schoolgezondheidsbeleid om een omslag in denken en handelen van zowel de preventieprofessionals als van de hele school. Om dit te kunnen realiseren zou de implementatie van schoolgezondheidsbeleid veel meer gezien moeten worden als een veranderproces binnen een organisatie en minder als het uitvoeren van activiteiten op scholen. Het is een veranderproces dat door de school gedragen moet worden. Daarom zou ook de schoolslag-adviseur meer aandacht moeten hebben voor de organisatorische aspecten van de implementatie van schoolgezondheidsbeleid. Deze aanbeveling sluit ook aan bij het flexibeler gebruiken van het stappenplan. Juist door in het stappenplan de organisatorische context van de school len dus ook acute hulpvragen) mee te nemen kan de schoolslag-adviseur beter tegemoetkomen aan de wensen en mogelijkheden van de school. Het belang van aandacht voor de organisatorische context van schoolgezondheidsbeleid wordt onderschreven in de review van Greenhalgh en anderen (2004), en het onderzoek van Deschesnes en anderen (2010).

Een belangrijke aanbeveling op basis van deze bevindingen is dan ook om meer te investeren in training en coaching van professionals, zowel de schoolslag-adviseurs als de contactpersonen van de scholen. Voor de school is het van belang te leren hoe gezondheid kan bijdragen aan de doelen van het onderwijs. Voor de training van de schoolslag-adviseur is informatie over de wijze waarop de organisatie van het onderwijs is vormgegeven en waar aanknopingspunten liggen voor gezondheid van belang. Door de complexiteit van het adviseringstraject dient de projectleider van de schoolslag-werkwijze een coachende rol in te nemen ten aanzien van de schoolslagadviseurs.

Landelijk wordt door CGL al veel geïnvesteerd in het trainen van schoolgezondheidsadviseurs uit de verschillende regio's. In samenwerking met Netherlands School of Public \& Occupational Health (NSPOH) is een scholingsaanbod opgesteld, variërend van het adviseren van scholen over de gezonde school als beleid, strategie en regie van de gezonde school. 
Binnen het internationale SHE-netwerk worden trainingen aangeboden voor de deelnemende landen gericht op de implementatie van schoolgezondheidsbeleid. De rol van de adviseur als procesbegeleider speelt ook in deze training een belangrijke rol (SHE, 2011).

\section{Implicaties voor theorievorming}

De onderzoeksvraag is gericht op de belemmerende en bevorderende factoren die een rol spelen bij de invoering van schoolgezondheidsbeleid middels de schoolslag-werkwijze. Om deze vraag te kunnen beantwoorden is met name gebruikgemaakt van het DISC-model.

In het DISC-model zijn elementen van zowel Rogers (1995), Fleuren, Wiefferink en Paulussen (2004) als Shediac-Rizkallah en Bone (1998) terug te vinden. Deze afzonderlijke modellen benaderen het innovatieproces ieder vanuit een andere invalshoek. Rogers (1995) neemt de marktinvoering als vertrekpunt voor zijn innovatiemodel, terwijl Fleuren, Wiefferink en Paulussen (2004) de nadruk leggen op zorginnovaties en Shediac-Rizakallah en Bone (1998) op continuering van een innovatieve inspanning. In het DISC-model zijn afzonderlijke elementen van de modellen samengevoegd en toegepast op de duurzaamheid van samenwerking bij de invoering van een innovatie zoals schoolgezondheidsbeleid. Aangezien de implementatie van schoolgezondheidsbeleid en de ontwikkeling van samenwerking tussen het onderwijsveld en het preventieveld binnen dit proces het centrale thema van het onderzoek is leek het DISC-model een geschikt theoretisch kader.

\section{Toepasbaarheid van het theoretische kader}

Voor het uitgevoerde onderzoek is het DISC-model als belangrijkste kader toegepast. Daarnaast worden de resultaten van het onderzoek geïnterpreteerd aan de hand van de modellen van Rogers (1995), Fleuren, Wiefferink en Paulussen (2004) en Shediac-Rizkallah en Bone (1998). Achteraf moeten we concluderen dat de gebruikte modellen aanknopingspunten hebben gegeven voor de interpretatie van de resultaten.

De belemmerende en bevorderende factoren genoemd door de respondenten, komen overeen met de factoren in de betreffende modellen. Ook de belemmerende en bevorderende factoren die naar voren kwamen in een vergelijking op organisatieniveau tussen de twee scholen waar de werkwijze het verst en het minst ver geïmplementeerd is, zijn terug te vinden in de modellen.

Daarnaast blijkt dat het gebruikte theoretisch kader overeenkomt met het recent geformuleerde model dat Deschesnes en anderen (2010) gebruikt hebben voor onderzoek naar de factoren die 
van invloed zijn op de adoptie van schoolgezondheidsbeleid in Quebec, Canada. Ook Deschesnes (2010) heeft voor de ontwikkeling van het theoretisch kader gebruikgemaakt van algemene innovatiemodellen. De indeling naar eigenschappen van de gebruiker, eigenschappen van de innovatie en eigenschappen van de setting, die veelal door innovatiemodellen wordt gehanteerd (Rogers, 1995; Shediac-Rizkallah \& Bone, 1998 en Fleuren, Wiefferink \& Paulussen, 2004), is vertaald naar de adoptie van schoolgezondheidsbeleid. Deze factoren zijn volgens Deschesnes (2010) ook van invloed op de adaptatie van schoolgezondheidsbeleid. Echter, in het model voegt hij de bereidheid om te werken aan schoolgezondheidsbeleid toe als mediërende factor. Daarbij geeft hij aan dat de factoren zowel rechtstreeks van invloed kunnen zijn op de adoptie van schoolgezondheidsbeleid, maar ook via de mediërende factor van bereidheid (Deschesnes, 2010). Het model van Deschesnes is oorspronkelijk ontwikkeld voor de adoptiefase van schoolgezondheidsbeleid. Ons onderzoek richt zich op de implementatiefase van schoolgezondheidsbeleid. Ondanks het verschil in adoptiefase en implementatiefase zijn de resultaten vergelijkbaar. Zowel het model van Deschesnes als de resultaten van het in dit proefschrift beschreven onderzoek benadrukken het belang van aandacht voor de organisatorische context van de adoptie danwel implementatie van schoolgezondheidsbeleid.

\section{Kanttekeningen bij het theoretische kader}

\section{Complexiteit van het DISC-model}

Het DISC-model is erg complex vormgegeven; het bevat veel verschillende factoren en toont, met de aanwezige pijlen, veel vormen van beïnvloeding. Een procesmodel zou binnen dit complexe geheel wellicht vereenvoudiging kunnen aanbrengen, doordat in een grafische weergave de afhankelijkheden tussen de activiteiten bij de implementatie van schoolgezondheidsbeleid kunnen worden weergegeven.

Binnen de huidige literatuur is op dit moment nog geen procesmodel beschikbaar voor de implementatie van een innovatie als schoolgezondheidsbeleid. De huidige modellen kiezen veelal voor een opsomming van factoren die een rol spelen bij de implementatie. Rogers (1995) en Fleuren, Wiefferink en Paulussen (2004) perken de veelheid aan factoren in en maken een indeling in verschillende groepen. Shediac-Rizkallah en Bone (1998) geven in hun model een overzicht van een veelheid aan factoren die een rol spelen bij de continuering van een innovatie. Alle genoemde modellen benoemen de factoren die volgens hun opvattingen een rol spelen bij innovatie, maar geven geen inzicht in de interactie tussen de verschillende factoren. Ook deze modellen zijn geen procesbeschrijving van de implementatie van een innovatie. Wel laten de afzonderlijke modellen de complexheid van het innovatieproces zien. Deschesnes (2010) doet in zijn onderzoek wel een aanzet voor een dergelijk model. Dit was echter nog niet beschikbaar ten tijde van de uitvoering van dit onderzoek. 


\section{Zichtbaarheid van resultaten}

De invoering van een innovatie als schoolgezondheidsbeleid is een intensief proces. De modellen van Rogers (1995), Fleuren, Wiefferink en Paulussen (2004) en Shediac-Rizkallah en Bone (1998) richten zich op de invoering van innovaties waarvan de effecten op korte termijn gemeten kunnen worden. De implementatie van schoolgezondheidsbeleid vraagt echter veel tijd en inspanning. De effecten zijn pas op lange termijn zichtbaar. Er kunnen op korte termijn wel effecten worden gemeten op basis van het aantal handelingen gericht op gezondheid binnen de school, echter duurzame implementatie, toename in gestructureerde interventies, invoering van het stappenplan en de uiteindelijke gezondheidseffecten bij leerlingen zijn pas na langere tijd meetbaar. Het feit dat de resultaten pas op lange termijn zichtbaar zijn werkt in het nadeel voor de implementatie van schoolgezondheidsbeleid. Bij de toepassing van het DISC-model dient rekening te worden gehouden met de lange looptijd van de implementatie van schoolgezondheidsbeleid. Bij implementatieprocessen van innovaties waarvan de effecten op korte termijn zichtbaar zijn, spelen juist deze effecten een belangrijke rol bij het creëren van draagvlak voor de innovatie. Bij de implementatie van schoolgezondheidsbeleid kan de overtuigingskracht niet worden gebaseerd op korte termijn effecten. Er zal actief gezocht moeten worden naar andere aspecten die voor een win-win kunnen zorgen. Zoals al eerder aangegeven zou bij dit proces de win-win gezocht moeten worden in het aanhaken van de meerwaarde van schoolgezondheidsbeleid aan de onderwijsdoelen.

\section{Eenzijdige focus op samenwerking}

Het DISC-model is ontwikkeld om een diagnose te kunnen stellen over de huidige status van samenwerking op het terrein van integraal gezondheidsbeleid rondom een gezamenlijk in te voeren innovatie. Doordat het model zich sterk focust op samenwerking bestaat het risico dat andere aspecten uit het oog worden verloren. Bij de ontwikkeling van de schoolslag-werkwijze is het DISC-model als basis gebruikt. Hierbij is veel geïnvesteerd in de procesmatige aspecten van de werkwijze. Er is een uitvoerige beschrijving gemaakt van de stappen die gezet moeten worden om te komen tot samenwerking en om een omslag van aanbod naar vraaggericht werken te kunnen realiseren. Door het gebruik van het DISC-model is de focus gelegd op samenwerking, enerzijds tussen de verschillende preventiepartners en anderzijds tussen de school en de schoolslag-adviseur. Terugkijkend op het implementatieproces kan geconcludeerd worden, dat deze focus heeft geleid tot een beperkte blik op het complexe geheel van implementatieprocessen. Bij de ontwikkeling van de werkwijze is de nadruk gelegd op factoren die de samenwerking beïnvloeden en minder op de factoren die de uiteindelijke implementatie beïnvloeden. Zo blijkt uit de resultaten dat bijvoorbeeld het creëren van draagvlak voor de werkwijze bij de eindgebruiker, het onderwijs, minder aandacht heeft gekregen. Als gevolg sluit de werkwijze onvoldoende aan op de wensen en mogelijkheden van het onderwijs en wordt het stappenplan ervaren als een keurslijf. Achteraf gezien kan dan ook worden geconcludeerd dat 
niet alle theoretische aspecten zijn toegepast. Zo is de factor aanpasbaarheid van de innovatie aan de wensen en mogelijkheden van de eindgebruiker onvoldoende toegepast bij de ontwikkeling van de schoolslag-werkwijze.

\section{Aanbevelingen voor aanpassing van het theoretische kader}

Op basis van het uitgevoerde onderzoek kunnen aanbevelingen worden gedaan voor aanpassing van het theoretische kader. Het complexe geheel vraagt om prioriteiten. Wat zijn de grootste problemen bij de implementatie van schoolgezondheidsbeleid en hoe kan inzicht in deze problemen het innovatieproces beïnvloeden? Op basis van het uitgevoerde onderzoek kunnen vier factoren worden benoemd die zeer sterk van invloed blijken te zijn op de implementatie van schoolgezondheidsbeleid:

1. Het nut van schoolgezondheidsbeleid voor het onderwijs.

Het vinden van aansluiting bij de doelstellingen van het onderwijs.

2. Draagvlak binnen het onderwijs voor schoolgezondheidsbeleid.

Wat is de meerwaarde van schoolgezondheidsbeleid voor het onderwijs?

3. Beschikbaarheid van tijd en middelen.

Gebrek aan tijd en energie. Er heerst een grote werkdruk en er is geen ruimte binnen het schoolsysteem.

4. Beschikbaarheid van de juiste competenties.

Anders denken vraagt om vakmanschap dat verder gaat dan het eigen vakgebied.

Wanneer we deze vier factoren naast het huidige DISC-model plaatsen moeten we concluderen dat draagvlak de enige factor is die binnen het huidige model een prominente rol inneemt. $\mathrm{Er}$ is binnen het DISC-model geen factor opgenomen gericht op het nut van schoolgezondheidsbeleid voor het onderwijs. Echter, de factor draagvlak is onderverdeeld in drie deelfactoren: percepties, intenties en acties. Bij percepties wordt wel de factor belang genoemd, dat is gerelateerd aan nut. Op basis van het uitgevoerde onderzoek zou deze factor wel een meer nadrukkelijke positie mogen innemen in het model. De factoren gericht op beschikbaarheid van tijd en middelen en de factor gericht op de beschikbaarheid van de juiste competenties zijn als zodanig niet opgenomen in het huidige DISC-model. Het verdient aanbeveling ook deze factoren op te nemen in het model.

Ook andere modellen bevatten slechts sommige van de vier belangrijkste factoren die op basis van het uitgevoerde onderzoek van invloed zijn op de implementatie van schoolgezondheidsbeleid. In het model van Rogers (1995) wordt eveneens het belang van nut van gezondheidsbeleid voor het onderwijs en de beschikbare tijd en middelen om deze innovatie in te voeren benadrukt. Rogers (1995) benoemt deze factoren als relatief voordeel en inpasbaarheid. In 1979 voegt Oldenburg wel de factor tijdsinvestering toe aan de factoren van Rogers. 
In het model van Shediac-Rizkallah en Bone (1998) kan een link worden gelegd met de beschikbaarheid van de juiste competenties. Shediac-Rizkallah en Bone (1998) benadrukken in hun model het belang van training. De overige factoren zijn niet terug te vinden in hun model.

Het model van Fleuren, Wiefferink en Paulussen (2004) onderschrijft het belang van alle genoemde factoren. Ze benoemen dat de innovatie een meerwaarde voor de cliënt moet hebben. Daarnaast wordt aangegeven dat de innovatie moet aansluiten bij de taakopvatting van de gebruiker. Deze factoren komen overeen met een factor nut van gezondheidsbeleid voor het onderwijs. Het model benadrukt, net als Deschesnes (2010), ook het belang van beschikbare tijd en middelen en de vaardigheden en kennis van de gebruiker.

Op basis van het uitgevoerde onderzoek zouden de elementen nut, draagvlak, tijd en middelen en beschikbaarheid van competenties een centrale positie dienen in te nemen in het DISCmodel. Aanvullend onderzoek is nodig om het doorontwikkelde DISC-model te toetsen in de praktijk.

Onlangs is door Universiteit Maastricht en GGD Zuid Limburg het DISC-project gestart, een onderzoek naar de samenwerking binnen het implementatieproces van schoolgezondheidsbeleid in het werkgebied van zes GGD'en op basis van het DISC-model. Binnen dit onderzoek wordt, in navolging van het uitgevoerde onderzoek, de wijze waarop de verschillende factoren het implementatieproces beïnvloeden nader onderzocht (ZonMw, 2006). Aangezien de onderzoeker als landelijke implementatie-adviseur betrokken is bij het DISC-project, worden de resultaten van het hier gerapporteerde onderzoek meegenomen.

\section{Reflectie op het uitgevoerde onderzoek}

Het uitgevoerde onderzoek naar de implementatie van schoolgezondheidsbeleid in de praktijk kenmerkt zich door verschillende eigenschappen. In eerste instantie is het een evaluatieonderzoek naar het implementatieproces van schoolgezondheidsbeleid. Daarnaast zijn de resultaten uit het onderzoek vertaald naar aanbevelingen en meteen toegepast in de dagelijkse praktijk. Dit maakt het onderzoek actiegericht. Het onderzoek is participatief, omdat de onderzoeker zelf onderdeel uitmaakte van de onderzoekspraktijk. Het onderzoek is ook voor een belangrijk gedeelte een case-studie binnen een specifieke regio. Bij de uitvoering van het onderzoek is gebruikgemaakt van de multi-method benadering door te kiezen voor een combinatie van kwalitatief en kwantitatief onderzoek. Hieronder wordt een reflectie gegeven op het uitgevoerde onderzoek. 


\section{Dynamiek van de omgeving}

Een onderzoek op het grensvlak van beleid, praktijk en wetenschap vraagt om flexibiliteit van de onderzoeker bij de uitvoering (Bak en anderen, 2007; Drukker, Maarschalkerweerd \& Bak, 2008; Tijssen, Van Raak, Mur-Veeman \& Maarse, 1992). De omgeving van het onderzoek is sterk dynamisch. De snelheid van veranderingen in deze omgeving is vaak hoger dan die van het onderzoek zelf. Dit kan leiden tot praktische problemen: gemaakte planningsafspraken bieden geen garantie voor daadwerkelijke uitvoering. Zo bleek dat, door een op het laatste moment ingelaste studiedag, de verspreiding van de vragenlijsten op een van de scholen een week werd uitgesteld. Maar ook op een ander niveau is de dynamiek herkenbaar: deelname aan onderzoek is een interventie op zich. Ook al is er in strikte zin geen sprake van een interventie, schoolgezondheidsbeleid kan alleen al door de evaluatie van beleid toch op de kaart gezet worden: de school wordt eraan herinnerd, de GGD weet zich bekeken. Tenslotte heeft onderzoek in de praktijk altijd te maken met externe factoren die direct of indirect het proces kunnen beïnvloeden. Zo is bijvoorbeeld binnen de overheid de discussie ontstaan over veiligheidsplannen binnen het onderwijs. Hierdoor komt veiligheid sneller op de agenda bij de schooldirectie dan voorheen. Omdat veiligheid en gezondheid binnen scholen qua thema dicht bij elkaar liggen kan dit leiden tot versnelde discussie over structureel schoolgezondheidsbeleid. Denk bijvoorbeeld aan thema's als drugs, alcohol, pesten, kindermishandeling, die zowel vanuit het perspectief van veiligheid als gezondheid benaderd kunnen worden.

\section{Academische werkplaats}

Het beschreven onderzoek is uitgevoerd binnen de Academische Werkplaats Publieke Gezondheid Limburg (Jansen en anderen, 2005). Binnen deze werkplaats ligt de nadruk op wetenschappelijk relevant onderzoek dat tevens maatschappelijke en praktische relevantie heeft (Jansen, 2007). De praktijk voedt het onderzoek met vraagstukken en data en de wetenschap draagt resultaten aan voor de toepassing in de praktijk. In de academische werkplaats leren professionals kritisch naar hun eigen handelingen te kijken en wetenschappelijke vragen te formuleren. Wetenschappers daarentegen krijgen de mogelijkheid hun onderzoeksresultaten toe te passen in de praktijk. Met het onderzoek beogen we een kritische reflectie te geven op de praktijk en deze te verbeteren. Gedurende het onderzoek is er een intensieve samenwerking geweest tussen de onderzoeker en het projectteam, dat vorm geeft aan de implementatie van schoolgezondheidsbeleid in Zuid-Limburg. Daarnaast is er structureel contact geweest met de schoolslag-adviseurs. Op die manier zijn veranderingen in de praktijk snel gesignaleerd en, indien nodig, aanpassingen aangebracht in de onderzoeksopzet. Daarnaast zijn de resultaten van het onderzoek meteen meegenomen in het implementatieproces en de begeleiding van de scholen. Door deze intensieve samenwerking hoefde relatief weinig tijd geïnvesteerd te worden in de werving van scholen voor deelname aan het onderzoek. In overleg met het projectteam en 
de schoolslag-adviseurs is getracht een goede balans te vinden voor de belasting van de scholen. Door het uitgevoerde onderzoek zoveel mogelijk op te nemen in het adviestraject, is het door de scholen niet als een extra onderzoeksbelasting ervaren. Scholen zijn niet overvraagd, aangezien dit de samenwerking negatief beïnvloedt. Het onderzoek leverde interessante gegevens op, zowel voor de scholen, de schoolslag-adviseurs, als het onderzoeksteam.

\section{Herkenbaarheid van de resultaten}

Een belangrijke vraag die bij veel onderzoeken gesteld moet worden is in hoeverre de resultaten generaliseerbaar zijn naar andere populaties, in dit geval andere regio's en scholen ('t Hart, Van Dijk, De Goede, Jansen \& Teunissen, 1996; Segers, 1983). Dit onderzoek is uitgevoerd bij scholen voor voortgezet onderwijs in één GGD-regio, die wel als voorloper op het terrein van schoolgezondheidsbevordering mag worden aangemerkt. Een belangrijke vraag is in hoeverre de resultaten uit deze regio bruikbaar zijn voor andere regio's. In hoofdstuk 2 zijn de resultaten vergeleken met andere GGD-regio's. Hier concluderen we dat de mogelijkheden en knelpunten die GGD'en en scholen noemen voor de invoering van schoolgezondheidsbeleid overeenkomen tussen de regio's. De wijze waarop schoolgezondheidsbeleid wordt geïmplementeerd bij de verschillende GGD'en verschilt met name in het aantal scholen en de keuze voor speciaal of regulier onderwijs. Daarnaast is erverschil in de wijze waarop de begeleiding intern georganiseerd is. Maar belemmerende en bevorderende factoren die GGD'en ervaren bij de scholen zoals hoge werkdruk, geen prioriteit, geen verplichting zijn dezelfde. De onderzoeker was ten tijde van het onderzoek tevens werkzaam als landelijke implementatie-adviseur schoolgezondheidsbeleid bij het DISC-project (ZonMw, 2006). In het kader van deze functie heeft de onderzoeker zes GGDregio's in Nederland begeleid bij de invoering en de vormgeving van schoolgezondheidsbeleid. De ervaringen bij deze regio's wijken niet af van de bevindingen in de onderzoeksregio.

Om subjectiviteit bij de interpretatie van de onderzoeksresultaten te minimaliseren zijn de resultaten zowel op landelijk als lokaal niveau getoetst bij experts. Op landelijk niveau zijn de gevonden resultaten door de onderzoeker besproken met de deelnemende regio's van het DISCproject. Het voornaamste doel was om te achterhalen of de gevonden resultaten ook herkenbaar waren voor de scholen in hun regio. Alle regio's gaven aan de situatie op hun scholen voor voortgezet onderwijs te herkennen in de gepresenteerde resultaten.

Op lokaal niveau zijn de resultaten door middel van terugkoppelingsgesprekken getoetst bij de zorgcoördinator en het management van het onderwijs. Deze gesprekken zijn gevoerd door de projectleider van de schoolslag-werkwijze en het afdelingshoofd van afdeling gezondheidsbevordering die de eindverantwoordelijkheid heeft over de schoolslag-werkwijze. De herkenbaarheid van de resultaten en conclusies was de voornaamste vraag die tijdens deze gesprekken 
centraal stond. Mede door de positieve reacties kan gesteld worden dat de gevonden resultaten generaliseerbaar zijn naar de brede schoolpopulatie.

Ook op internationaal niveau zijn de resultaten van het onderzoek toepasbaar, maar de problemen bij de invoering zullen verschillen van land tot land. Per land is de uitgangssituatie verschillend. Zo is de wetgeving overal anders en is publieke gezondheid vaak anders georganiseerd.

\section{Toepasbaarheid van specifieke theorie}

In de literatuur zijn verschillende implementatietheorieën beschreven die zich met name richten op de implementatie van concrete activiteiten (Fleuren en anderen, 2004; Nutbeam, 1992; Rogers, 1995; Shediac \& Bone, 1998). Ten aanzien van schoolgezondheidsbeleid kenmerkt de literatuur zich door praktijkbeschrijvingen van concrete activiteiten zoals bijvoorbeeld de aanpak van pesten binnen scholen (Green \& Tones, 2000; Inchley en anderen, 2000; Moon, 2000; Mukoma \& FliSHEr, 2004; Parsons \& Stears, 2002). In dit proefschrift staat implementatie van beleid centraal. Het implementatieproces betreft dan ook geen concrete activiteiten, maar een werkwijze die vorm moet krijgen en flexibel inzetbaar moet zijn, afhankelijk van de mogelijkheden van de betreffende school (Leurs, 2008). Dit vraagt om een andere theoretische benadering dan wat in het verleden gedaan is. Dit heeft ertoe geleid dat met input van praktijkprofessionals en wetenschappers meetinstrumenten zijn ontwikkeld op basis van de schoolslag-werkwijze (Leurs en anderen, 2006) en bestaande implementatietheorieën.

\section{Samenstelling onderzoeksgroep}

Binnen deel 3 van dit proefschrift zijn gegevens verzameld bij een zeer beperkte onderzoeksgroep. Dit kon echter niet anders, aangezien gekozen is voor een implementatieonderzoek binnen één van de regio's die actief zijn op het terrein van schoolgezondheidsbeleid. Binnen deze regio zijn alle betrokken scholen benaderd voor deelname en heeft een ruime meerderheid deelgenomen. De wijze van implementatie van schoolgezondheidsbeleid verschilt per regio. Zeker de wijze waarop scholen begeleid worden. Daarom is ervoor gekozen één casus goed uit te diepen en de onderzoekspopulatie niet uit te breiden met andere regio's. Dit vraagt een andere methodiek dan een multiple-case-studie waarin het implementatieproces van verschillende regio's onderzocht wordt. Voor dit proefschrift is gekozen om nader de diepte in te gaan bij één regio. Echter, binnen het DISC-onderzoek (ZonMw, 2006), waarbij de onderzoeker als implementatieadviseur betrokken is, is wel gekozen voor een multiple-case-studie. De resultaten van dit project worden eind 2012 verwacht. 
Voor het onderzoek gericht op de extreme cases, zijn de deelnemende scholen op basis van de toepassing van het schoolslag-stappenplan gerangschikt en zijn de twee uiterste scholen geselecteerd.

Het onderzoek, gericht op de interne validiteit, bruikbaarheid en betrouwbaarheid van de schoolslag-checklist, stond los van de geselecteerde regio. De onderzoekspopulatie voor het onderzoek naar de interne validiteit bestond uit 22 experts, betrokken bij de kwaliteit van de ontwikkeling, implementatie, uitvoering of evaluatie van preventieprogramma's op zowel regionaal als landelijk niveau, allen afkomstig van buiten het initiële toepassingsgebied van de schoolslag-werkwijze. Door beperkte mogelijkheden in tijd en middelen is het onderzoek naar de interne validiteit, bruikbaarheid en betrouwbaarheid van de schoolslag-checklist kleinschalig opgezet. Een tekortkoming hierdoor is het ontbreken van een vertegenwoordiging vanuit het onderwijs. De onderzoekspopulatie van het onderzoek naar de bruikbaarheid en betrouwbaarheid van de schoolslag-checklist bestond wel uit een evenredige verdeling van afgevaardigden uit het onderwijs en de gezondheidssector.

\section{Aanbevelingen voor verder onderzoek}

Het beschreven onderzoek geeft inzicht in de wijze waarop gezondheidsbevordering structureel kan worden ingebed binnen het beleid en de praktijk van scholen voor voortgezet onderwijs (kopje voornaamste bevindingen). In deze paragraaf worden op basis van de ervaringen verschillende aanbevelingen voor verder onderzoek gegeven.

\section{Schoolgezondheidsbeleid versus interventies}

Bij de uitvoering van de review in hoofdstuk 1 is met name gefocust op de relatie tussen gezondheidsbevorderende activiteiten en leerprestaties. Het aantonen van deze relatie zegt echter nog niets over de effectiviteit van schoolgezondheidsbeleid met betrekking tot verhoging van leerprestaties. Beleid is meer dan een interventie alleen. Om deze vraag te kunnen beantwoorden zullen dus eerst de effecten van gezondheidsbevorderende interventies of een samenhangend geheel van interventies in kaart gebracht moeten worden. Wanneer de effecten van de interventies bekend zijn, zouden deze gebruikt kunnen worden om meer te weten te komen over de samenhang en synergie tussen de afzonderlijke interventies. De resultaten van dergelijk onderzoek kunnen uiteindelijk ook bijdragen aan het inzichtelijk maken van het effect van structureel schoolgezondheidsbeleid. Voor deze vorm van onderzoek is het wenselijk dat de implementatie van schoolgezondheidsbeleid verder gevorderd is. In deze fase van implementatie zou wel gekozen kunnen worden voor een onderzoek bij enkele pilot-scholen. Mogelijk dat de 
resultaten van het beschreven onderzoek kunnen bijdragen aan een bredere implementatie van schoolgezondheidsbeleid, zodat in de toekomst de vervolgstap naar effectiviteitsonderzoek van de implementatie schoolgezondheidsbeleid gezet kan worden.

\section{Schoolgezondheidsbeleid versus geen schoolgezondheidsbeleid}

Door de stimulerende rol van het CGL bij de landelijke implementatie van de Gezonde School en de ontwikkeling van een handreiking voor GGD'en die scholen willen begeleiden bij de invoering van schoolgezondheidsbeleid, ontstaat wellicht de mogelijkheid om een vergelijkend onderzoek uit te voeren naar de invoering van schoolgezondheidsbeleid in andere regio's. Waar in ZuidLimburg alle scholen voor voortgezet onderwijs benaderd zijn voor de implementatie van schoolgezondheidsbeleid, hebben andere regio's de keuze gemaakt slechts een beperkt aantal scholen te benaderen. In deze regio's zou een RCT-onderzoek met een vergelijking tussen scholen die wel op een systematische wijze werken aan schoolgezondheidsbeleid en scholen die niet op een systematische wijze werken aan schoolgezondheidsbeleid wenselijk zijn. Echter, de complexiteit van het onderzoek is te groot om een RCT-onderzoek uit te kunnen voeren. $\mathrm{Er}$ zijn teveel randvoorwaardelijke factoren die niet te beïnvloeden zijn. In deze situatie kan beter gekozen worden voor een quasi-experimenteel onderzoek of een veld-experiment.

\section{Schoolgezondheidsbeleid versus gezondheidsbevorderende activiteiten}

Het huidige onderzoek richtte zich op de implementatie van schoolgezondheidsbeleid. Voor de onderbouwing van de werkwijze is, naast kennis over het proces van schoolgezondheidsbeleid, ook kennis over de daadwerkelijke activiteiten die worden uitgevoerd ten gevolge van schoolgezondheidsbeleid van belang. Inzicht in de daadwerkelijke uitvoering van activiteiten op basis van de gekozen prioriteiten kan extra informatie geven over de output van schoolgezondheidsbeleid. In de toekomst zou op basis van de beschreven plannen en de uitgevoerde activiteiten bekeken kunnen worden, in hoeverre deze investeringen terug te zien zijn in de resultaten van het jongerenonderzoek, een periodieke peiling van de gezondheid van de jeugd. Deze onderzoeksgegevens kunnen bijdragen aan de onderbouwing van de noodzaak voor schoolgezondheidsbeleid in het onderwijs. Bij deze vorm van onderzoek is het wel van belang rekening te houden met het feit dat de effecten van gezondheidsbevorderende activiteiten gericht op gedrag, pas op langere termijn meetbaar zijn. Bij dergelijk onderzoek is het dan ook aan te raden onderscheid te maken in effect op kennis, houding en gedrag. 


\section{Slotwoord}

De afgelopen vier jaar is hard gewerkt aan de implementatie van schoolgezondheidsbeleid. Het accent is verlegd van concrete interventie naar een werkwijze die adaptief is naar wat scholen nodig hebben. Na alle investeringen hebben de gemeenten in Zuid-Limburg de schoolslagwerkwijze als basisproduct omarmd. Dat wil echter niet zeggen dat het werk hier stopt. De doorontwikkeling van de schoolslag-werkwijze is een continu proces van uitvoeren, evalueren en bijstellen. De resultaten van dit onderzoek bieden een goede basis om de kwaliteit van de werkwijze te verbeteren en te blijven monitoren.

Landelijk is veel werk verzet om schoolgezondheidsbeleid op de agenda te krijgen bij GGD'en, maar ook bij de overheid en andere landelijke partijen. Mede door het pionierswerk in ZuidLimburg is landelijk een werkwijze beschikbaar voor GGD'en die scholen willen begeleiden bij de invoering van schoolgezondheidsbeleid.

De pleitbezorging voor schoolgezondheidsbeleid zal nooit ten einde komen, ook echte liefde moet je onderhouden. Voor een goede borging heb je continu aandacht nodig. Echter, wanneer er sprake is van echte liefde zal deze aandacht als vanzelfsprekend onderdeel uitmaken van het huwelijk. Dit onderzoek leert ons dat Cupido nog niet heeft toegeslagen en dat tussen gezondheidsbevordering en het onderwijs nog geen echte liefde is opgebloeid. Er is hoogstens een vonkje ontstaan dat interesse in elkaar oproept. Het beschreven onderzoek (temidden van andere ontwikkelingen) heeft ertoe bijgedragen dat beide werelden meer begrip voor elkaar hebben gekregen en zelfs een verstandshuwelijk overwegen. De toekomst zal ons leren of het vonkje voldoende is om, met behulp van alle investeringen zowel landelijk als lokaal, om te kunnen slaan in een langdurige relatie gebaseerd op echte liefde. 


\title{
Referenties
}

\section{Summary}

Samenvatting

\author{
Dankwoord
}

\section{Curriculum Vitae}

Publicatie overzicht 


\section{Referenties}

Aarnio, M., Winter, T., Kujala, U., \& Kaprio, J. (2002). Associations of health related behaviour, social relationships, and health status with persistent physical activity and inactivity: a study of Finnish adolescent twins. British Journal of Sports Medicine, 36(5), 360-364.

Adams PF, S. C., Warren, CW, Kann L. (1995). Health risk behaviors among our nation's youth: United States 1992. Vital and Health Statistics, 10(192), 1-51.

Aggleton, P., Rivers, K., Mulvihill, C., Chase, E., Downie, A., Sinkler, P., en anderen (2000). Lessons learned: working toward the National Healthy School Standard. Health Education 100(3), 102-110.

Ahamed, Y., Macdonald, H., Reed, K., Naylor, P. J., Liu-Ambrose, T., \& McKay, H. (2007). Schoolbased physical activity does not compromise children's academic performance. Medicine \& Science in Sports \& Exercise, 39(2), 371-376.

Alexander, K. L., Entwisle, D. R., \& Olson, L. S. (2001). Schools, Achievement, and Inequality: A Seasonal Perspective. Educational Evaluation and Policy Analysis, 23(2), 171-191.

Allensworth, D. (1993). Health education: state of the art. Journal of School Health, 63, 14-20.

Allensworth, D.D., Wyche, J., Lawson, E. \& Nicholson, L. (1995). Defining a Comprehensive School Health Program: An Interim Statement. Division of Health Science Policy, National Academy Press, washington, DC.

Altman, D.G., Balcazar, F.E., Fawcett, S.B., Seekins, T.M., \& Young, J.Q. (1994). Public health advocacy: creating community change to improve health. Palo Alto, CA: Stanford Center for Research in Disease Prevention.

Bada, E., Sokou, K., Dafesh, Z., Lee, A., Flaschberger, E., Buijs, G. (2009). HEPS Advocacy Guide: Arguments and strategies towards a health policy. Woerden, NIGZ.

Bak, M., Os, J., van Delespaul, Bie, A., de Campo, J., Poddighe, G., en anderen (2007). An observational 'real life' trial of the introduction of Assertive Community Treatment in a geographically defined area using clinical rather than service use outcome criteria. Soc. Psychiatry Psychiatric Epidemiology, 42(2), 125 - 130.

Barnekow, V., Buijs, G., Clift, S., Bruun Jensen, B., Paulus, P., Rivett, D. \& Young, I. (2006). Healthpromoting schools: a resource for developing indicators. Copenhagen: International Planning Committee of the European Network of Health Promoting Schools.

Bartholomew, L. K., Parcel, G. S., Kok, G. J., \& Gottlieb, N. H. (2001). Intervention mapping: designing theory- and evidence based health promotion programs. Mountain View, CA: Mayfield.

Bartholomew, L. K., Parcel, G. S., Kok, G., \& Gottlieb, N. H. (2006). Planning health promotion programs. An intervention Mapping Approach (2 ed.). San Fransisco: Jossey-Bass. 
Battel-Kirk, B., Barry, M.M., Taub, A. en anderen. (2009) A review of the international literature on health promotion competencies: identifying framework and core competencies, Global Health Promotion Vol. 16 (2) 12.

Bellisle, F. (2004). Effects of diet on bahaviour and cognition in children. Br. J. Nutr., 92(2), 227232.

Berg, B.L. (2004). Qualitative Research Methods for the Social Sciences (5th. Ed.). Totonto: Pearson.

essems. K., D. R. S., Buijs. G. (2006). Toolkit overgewicht-preventie van overgewicht binnen de setting school. Woerden: NIGZ.

Boddy, D. (1999). The evidence of health promotion effectiveness: shaping a new public health in Europe. European Journal of Public Health, 9(4).

Bodelier, R. (2009). Zorg- en adviesteams in het hele land. Utrecht: Nederlands Jeugd Instituut.

Boonen, A., de Vries, N., de Ruiter, S., Bowker, S. \& Buijs, G. (2009) HEPS Guidelines. Guidelines on promoting healthy eating and physical activity in schools. Woerden, NIGZ.

Boot, M. W. M., van Assema, P., Hesdahl, B., \& de Vries, N. K. (2010). Professional assistance in implementing school health policies. Health Education, 110(4), 294-308.

Boot, N. (2010). Bijlage instrument samenwerking. In Handleiding Gezonde School. Bilthoven: Centrum Gezond Leven - RIVM.

Boot, N. M. W. M., Leurs, M. T. W., Peters, L. W. H., Keijsers, J. F. E. M., Schaalma, H. P., \& De Vries, N. (2005). Evaluatie van de schoolSlag-checklist gericht op het beoordelen van de kwaliteit van schoolse interventies [Evaluation of the schoolBeat-checklist assessing the quality of school-based interventions]. Tijdschrift voor Gezondheidswetenschappen, 83(7), 405-411.

Boot, N. M. W. M., Van Assema, P., Hesdahl, B., Leurs, M., \& De Vries, N. K. (2010a). Gezondheidsbevordering en voortgezet onderwijs: verstandshuwelijk of echte liefde? TSG, 88(3), 127-135.

Boot, N. M. W. M., Van Assema, P., Hesdahl, B., Leurs, M., \& De Vries, N. K. (2010b). Gezondheidsbevordering en voortgezet onderwijs: verstandshuwelijk of echte liefde? Tijdschrift voor Gezondheidswetenschappen, 88(3), 135-143.

Bos, V., De Jongh, D., \& Paulussen, T. (2010). Gezondheidsbevordering en preventie in het onderwijs. Stand van zaken, effectiviteit en ervaringen van GGD'en en scholen. Bilthoven: RIVM.

Bosdriesz, M., \& Berkenbosch, W. (2003). Jeugdzorgadviesteams voor het basisonderwijs. Methodiek voor de aansluiting van basisonderwijs en jeugdzorg [Youth care advisory teams for primary education. A method for linking primary education with youth care]. Utrecht: NIZW.

Bracht, N. and Kingsbury, L. (1990) Community organization principles in health promotion: a five stage model. In Bracht, N. (ed.) Health Promotion at the Community level. Sage, Newbury Park, CA. 
Brener, N.D., Dittus, P.J. \& Hayes, G. (2001) Family and community involvement in schools: the results from the School Health Policies and Program Study 2000. Journal of School Health, 71, 340-350.

Brug, J., \& Schaalma, H. (2000). Gezondheidsvoorlichting en gedragsverandering, een planmatige aanpak. Assen/Maastricht: Van Gorcum.

Brug, J., Dale, D., Lanting, L., Kremers, S., Veenhof, C.,Leurs, M.,van Yperen, T. \& Gerjo Kok (2010). Towards evidence-based, quality-controlled health promotion: the Dutch recognition system for health promotion interventions. Health Education research Vol.25 no.6. Pages 1100-1106

Bruins, Y. (2002). Monitor voor Jeugdzorg Advies Teams in het voortgezet onderwijs. Spectrum Actueel, 4, 11.

Canadian Association for School Health (1991) Comprehensive School Health: A Consensus Statemen. Surrey, BCM.

Carlson, S. A.; Fulton, J. E.; Lee, S. M.; Maynard, L. M.; Brown, D. R.; Kohl, H. W., 3rd and Dietz, W. H. (2008) Physical education and academic achievement in elementary school: data from the early childhood longitudinal study. Am J Public Health, 98, 721-727.

CDC. (2007). Youth Risk Behavior Surveillance-Selected Steps Communities.

Cheshlarov, M., Havlínová, M., Inchley, J., Jakonen, S., Jankulovska, S., Jensen, B. B., en anderen (2002). Models of health promoting schools in Europe. Copenhagen: WHO Regional Office for Europe.

Chomitz. VR., S. M., McGowan. RJ., Mitchell. SE., Dawson. GF., Hacker. KA. (2009). Is there a relationship between physical fitness and academic achievement? Positive results from public school children in the Northeastern United States. Journal of school health, 79(1), 30-37.

Clift, S., Jensen, B. B., \& (eds.). (2005). The health promoting school: international advances in theory, evaluation and practice. Copenhagen: Danish University of Education Press.

Coe, D. P., Pivarnik, J. M., Womack, C. J., Reeves, M. J., \& Malina, R. M. (2006). Effect of physical education and activity levels on academic achievement in children. Medicine \& Science in Sports \& Exercise, 38(8), 1515-1519.

Cohen, J. (1988). Statistical power analysis for the behavioral sciences. Mahwah, NJ: Erlbaum.

Cohen, J. (1992). A power primer. Psychological Bulletin, 112(1), 155-159.

Crone M.R., Spruijt R., Dijkstra N.S., Willemsen M.C., Paulussen T.G.W.M. Does a smoking prevention program in elementary schools prepare children for secondary school? Preventive medicine, 52, 53-59.

Cutler DM, Lleras-Muney A (2006). Education and health: evaluating theories and evidence. Cambridge, MA, NBER (Working Paper No. 12352). 
Dadaczynski, K., Paulus, P., de Vries, N., de Ruiter,S. \& Buijs, G. (2010) HEPS Inventory Tool. An inventory tool including quality assessment of school interventions on healthy eating and physical activity. HEPSeurope.eu.

Dafesh, Z. J. A., Buijs, G. J., Hekkink, K., Drossaert, C. H. C., \& Boer, H. (2006). Regioscan GGD en Gezondheid op scholen. Onderzoek naar de stand van zaken rond de ondersteuning van scholen door GGD'en op het terrein van gezondheid [Region scan of public health services and health at schools. Study into school health support by public health services]. Woerden / Enschede: NIGZ / Universiteit Twente.

Davis, J. M., \& Cooke, S. M. (2007). Educating for a healthy, sustainable world: An argument for integrating Health Promoting Schools and Sustainable Schools. Health Promotion International, 22(4), 346-353.

De Jongh, D., Blokdijk, L., \& Leurs, M. (2009). School health promotion and prevention in the Netherlands, Health Promoting Schools Conference. Vilnius.

De Jongh, D., Bos, V., van Bommel, H., Boot, N., Bos, H., Gardien, M., en anderen (2010). Handleiding Gezonde School Basisonderwijs. Bilthoven: RIVM Centrum Gezond Leven.

De Vreede, J., Rademaker, C. W., Gras, A., \& Leurs, M. T. (2003). Jongerenonderzoek 2001: Resultaten scholiewrenonderzoek Regio Zuidelijk Zuid-Limburg. Maastricht: GGD Zuidelijk Zuid-Limburg.

De Vries, N. (2004). Waartoe een referentiekader kan dienen? TSG Tijdschrift voor Gezondheidswetenschappen, 4, 213.

Deschesnes, M., Couturier,Y., Laberge, S. \& Campeau.L. (2010). How divergent conceptions among health and education stakeholders influence the dissemination of healthy schools in Quebec. Health Promotion International vol. 25 No. 4 pag 435-443.

Deschesnes, M., Martin, C., \& Hill, A. J. (2003). Comprehensive approaches to school health promotion: how to achieve broader implementation? Health Promotion International, 18(4), 387-396.

Deschesnes, M., Trudeau, F.\& Kébé. M. (2010). Factors influencing the adoption of a Health promoting School approach in the province of Quebec, Canada. Health Education research. Vol. 25. no. 3 page 438-450.

DeSocio, J., \& Hootman, J. (2004). Chilrden's Mental Health and School Success. The Journal of School Nursing, 20(4), 188-196.

Dijkstra, A. (2004). De schoolarts in Nederland. Tijdschrift Jeugdgezondheidszorg, 36(5), 89-92.

Ding W en anderen (2006). The impact of poor health on education: new evidence using genetic markers. Cambridge, MA, NBER (Working Paper No. 12304).

DISC-analyses (pp. 27). Universiteit Maastricht, GGD Zuid Limburg \& NIGZ.

Drukker, M., Maarschalkerweerd, M., \& Bak, M. (2008). A real-life observational study of the effectiveness of FACT in a Dutch mental health region. BMC Psychiatry, 8, 93. 
Dunkle MC, N. M. (1991). Beyond the Health Room. Washington, DC: Council of Chief State School Officers, Resource Center on Educational Equity.

Fekkes, M., \& Paulussen, T. (2010). Effecten van gezondheidsbevordering in het onderwijs op de leefstijl, schoolprestaties en -uitval van leerlingen; een literatuurreview. In Gezondheidsbevordering en preventie in het onderwijs. Stand van zaken, effectiviteit en ervaringen van GGD'en en scholen (pp. 19-40).

Fetro, J.V. (1998) Implementing coordinated school health programs in local schools. In Marx, E., Wooley, S.F., \& Northrop, D. (eds) Health is Academic. Teachers College Press, NY, pp $15-42$.

Fleuren, M. A. H., \& De Jong, O. R. W. (2006). Basisvoorwaarden voor implementatie en borging van de standaarden Jeugdgezondheidszorg. (No. KvL/B\&G 2006.075). Leiden: TNO Preventie en Gezondheid.

Fleuren, M. A. H., Wiefferink, C. H., \& Paulussen, T. G. W. M. (2002). Belemmerende en bevorderende factoren bij de implementatie van zorgvernieuwingen in organisaties [Inhibiting and enhancing factors for the implementation of care innovations in organizations]. Leiden: TNO Preventie en Gezondheid.

Fleuren, M., Wieferink, K., \& Paulussen, T. (2004). Determinants of innovation within health care organizations. Literature review and Delphi study. International Journal for Quality in Health Care, 16(2), 107-123.

Florence. M.D., Asbridge. M, \& Veugelers. PJ. (2008). Diet quality and academic performance. Journal of school health, 78(4), 209-215.

Flynn, B.S. (1995) Measuring community leaders' perceived ownership of health education programs: initial tests of reliabiliy and validity. Health Education Research, 10, 27-36.

Fullan, M. (2001). The new Meaning of Educational Change. (third ed.). New York: Teachers Coles Press.

Gabhainn, S. N., Sixsmith, J., Delaney, E., Moore, M., Inchley, J., \& O’Higgins, S. (2007). Healthpromoting school indicators: schematic models from students. Health Education, 107(6), 494-510.

Gan L, Gong G (2007). Estimating interdependence between health and education in a dynamic model. Cambridge, MA, NBER (Working Paper No. 12830).

GGD Nederland. (n.d.-a). Beleidsterreinen. from http://www.ggd.nl/beleidsterreinen/ (2011)

GGD Nederland. (n.d.-b). Organisatie. from http://www.ggd.nl/over-ggd-nederland/organisatie/ (2011)

GGD Nederland. (n.d.-c). Partners. from http://www.ggd.nl/over-ggd-nederland/partners (2011)

Green, J., \& Tones, K. (2000). The Health Promoting School, general practice and the creative arts. Health Education, 100, 124-130. 
Greenberg, M. T., Weissberg, R. P., O’Brien, M. U., Zins, J. E., Fredericks, L., Resnik, H., en anderen (2003). Enhancing school-based prevention and youth development through coordinated social, emotional, and academic learning. Am Psychol, 58(6-7), 466-474.

Greenhalgh T, Robert G, MacFarlane F en anderen Diffusion of innovations in service organizations: systematic review and recommendations. Milbank Q 2004; 82: 581-629.

Grossman M (1973). The correlation between health and schooling. Cambridge, MA, NBER (Working Paper No. w0022).

Hart, ‘t H., Van Dijk, J., De Goede, M., Jansen, M. W., \& Teunissen, J. (1996). Onderzoeksmethoden. Amsterdam: Boom.

HEPS. (2011). http://www.HEPSeurope.eu/.

Hollar, D., Messiah, S. E., Lopez-Mitnik, G., Hollar, T. L., Almon, M., \& Agatston, A. S. (2010). Effect of a two-year obesity prevention intervention on percentile changes in body mass index and academic performance in low-income elementary school children. American Journal of Public Health 100(4), 646-653.

Inchley, J., Currie, C., \& Young, I. (2000). Evaluating the health promoting school: a case study approach. Health Education, 100(5), 200-206.

Inspectie van het Onderwijs. (2009). Jaarwerkplan 2010: Activiteiten inspectie van het onderwijs. Utrecht: Ministerie van Onderwijs, Cultuur en Wetenschap.

Inspectie voor de gezondheidszorg. (2005). Openbare gezondheidszorg: hoe houden we het volk gezond? Den Haag: IGZ.

Jansen, M. W. J. (2007). Mind the gap: collaboration between practice, policy and research in local public health., Maastricht University, Maastricht.

Jansen, M., Spreeuwenberg, C., \& De Vries, N. (2005). Van praktijk naar bewijsvoering en beleid en vice versa. Academisch Centrum voor Publieke gezondheid Limburg. Maastricht: GGD Zuid Limburg, Universiteit Maastricht, Academisch Ziekenhuis Maastricht.

Jansen, M.W.J. Mind the gap: Collaboration between practice, policy and research in local public health. Dissertation. Maastricht: Universiteit Maastricht, 2007. Datawyse/UM ISBN 978-90-5278-626-1.

Jeugdinstituut, N. (2009). www.ZAT.nl. from J21

Kolbe, L.J., Kann, L. \& Brener, N.D. (2001) Overview and summary of findings: School Health Policies and Programs Study 2000. Journal of School Health, 71, 253-259.

Leurs MT, Schaalma HP, Jansen MW en anderen Comprehensive quality assessment of healthy school interventions. Prev Med 2007; 45: 366-72.

Leurs, M. (2003). Gezondheidsbevordering in het onderwijs: de schoolSlag-uitdaging [Health promotion in education: the schoolBeat-challenge]. Remediaal, 4(1), 3-8.

Leurs, M. (2008). A collaborative approach to tailored whole-school health promotion. The schoolBeat study. Maastricht University, Maastricht/Amersfoort. 
Leurs, M. T. W., Mur-Veeman, I. M., Van der Sar, R., Schaalma, H. P., \& De Vries, N. K. (2008). Diagnosis of sustainable collaboration in health promotion - a case study. BMC Public Health, 8(382), 1-15.

Leurs, M. T. W., Schaalma, H. P., Jansen, M. W. J., Mur-Veeman, I. M., St.Leger, L. H., \& De Vries, N. K. (2005). Development of a collaborative model to improve school health promotion in the Netherlands. Health Promotion International, 20(3), 296-305.

Leurs, M. T., Mur-Veeman, I., Schaalma, H. P., \& Vries de, N. (2003). Integrale samenwerking gaat verder dan de samenwerking tussen professionals: introductie van het DISC-model. TSG, 81(6), 369-373.

Leurs, M., \& Jansen, M. (2002). Schoolbeat - the new Challenge. Network News of the European Network of Health Promoting Schools, 7, 26-28.

Leurs, M., Bessems, K., Schaalma, H., \& De Vries, H. (2007). Focus points for school health promotion improvements in Dutch primary schools. Health Education Research, 22(1), 58-69.

Leurs, M., en anderen (2005). The Tailored Schoolbeat-Approach: New Concepts for Health Promotion in Schools in The Netherlands. In The Health Promoting School: International Advances in Theory, Evaluation and Practice (pp. 89-107). Copenhagen: Danish University of Education Press.

Leurs, M., Jansen, M., \& Feron, F. (2004). From school health promotion to integrated school health care - schoolBeat in the Netherlands. Network News - the European Network for Health Promoting Schools, 8, 22.

Leurs, M., Jansen, M., \& Ruiter, M. (2002). Coordinated School Health Program: het 'Gezonde School Model' van de toekomst? [CSHP: the Healthy School Model of the future?]. Tijdschrift voor Gezondheidswetenschappen, 80(7), 471-473.

Leurs, M., Jansen, M., Schaalma, H., Mur-Veeman, I., \& De Vries, N. (2005). The Tailored Schoolbeat-Approach: New Concepts for Health Promotion in Schools in The Netherlands. In S. Clift \& B. B. Jensen (Eds.), The Health Promoting School: International Advances in Theory, Evaluation and Practice (1st ed., pp. 89-107). Copenhagen: Danish University of Education Press.

Leurs, M., Schaalma, H., Jansen, M., Mur-Veeman, I., St.Leger, L., \& De Vries, N. (2005). Development of a collaborative model to improve school health promotion in the Netherlands. Health Promotion International, 20(3), 296-305.

Leurs, M., Steenbakkers, M., \& Jansen, M. (2006). Het schoolSlag-praktijkboek: samen werken aan preventie op maat in het onderwijs [the schoolBeat-manual: working together towards tailored prevention in education]. Maastricht: GGD Zuid Limburg.

Lister-Sharp, D., Chapman, S., Stewart-Brown, S., \& Sowden, A. (1999). Health promoting schools and health promotion in schools: two systematic reviews. Health Technology assessment, 3(22). 
Lynagh, M., Schofield, M. \& Sanson-Fisher, R. (1997) School HealthPromoting Programs over the past decade: a review of the smoking, alcohol and solar protection literature. Health Promotion International, 12, 43-60.

Mackenbach J (2003). Tackling inequalities in health: the need for building a systematic evidence base. Journal of Epidemiology and Community Health, 57, 162.

Mackenbach, J.P., van der Maas P.J. (2010). Volksgezondheid en gezondheidszorg, Elsevier gezondheidszorg.

Marshall, B.J., Sheehan, M.M., Northfield, J.R., Maher, S., Carlisle, R. \& St Leger, L.H. (2000) School-based health promotion across Australia. Journal of School Health, 70, 251252.

Marx, E., \& Wooley, S. F. (1998). Health is Academic - A Guide to Coordinated School Health Programs. New York: Teachers College Press.

Meyers, A. F., Sampson, A. E., Weitzman, M., Rogers, B. L., \& Kayne, H. (1989). School Breakfast Program and school performance. American journal of diseases of children, 143(10), 1234-1239.

Ministerie van OC\&W. (2001). Nota Kwaliteit aan de basis [Policy Quality at the basics]. Den Haag: SDU.

Ministerie van Volksgezondheid, W. e. S. (2003). Langer Gezond Leven: ook een kwestie van gezond gedrag. Den Haag: Ministerie van Volksgezondheid, Welzijn en Sport.

Ministerie van VWS. (2007). Gezond zijn, gezond blijven. Een visie op gezondheid en preventie. Den Haag: Ministerie van Volksgezondheid, Welzijn en Sport.

Molleman, G. R. M., \& Hosman, C. M. H. (2003). Ontwikkeling van een kwaliteitsinstrument voor de effectiviteit van gvo/preventie-programma's - De Preffi 1.0; ontwikkeling, ervaringen en uitgangspunten voor een Preffi 2.0 [Development of a quality instrument for the effectiveness of health promotion programs the Preffi 1.0; development, experiences and guidelines for a Preffi 2.0]. Tijdschrift voor Gezondheidswetenschappen, 81(5), 238246.

Molleman, G. R. M., Peters, L. W. H., Hosman, C. M. H., Hommels, L. M., Ploeg, M. A., Kok, H. H., en anderen (2003). De Preffi 2.0: systematische ontwikkeling van een kwaliteitsinstrument voor gezondheidsbevordering [The Preffi 2.0: systematic development of a quality instrument for health promotion]. Tijdschrift voor Gezondheidswetenschappen, 81(5), 247-255.

Moon, A. (2000). Evaluating the health-promoting school. Health Education, 100(4), 237-241.

Mukoma, W., \& Flisher, A. J. (2004). Evaluations of health promoting schools: a review of nine studies. Health Promotion International, 19(3), 357-368.

Murray, N. G., Low, B. J., Hollis, C., Cross, A. W., \& Davis, S. M. (2007). Coordinated school health programs and academic achievement: a systematic review of the literature. Journal of School Health, 77(9), 589-600. 
Mur-Veeman, I., \& Van Raak, A. (1994). Interorganisational networks on the Dutch home health care market. International Journal of Health Planning and Policy, 9, 245-258.

Nutbeam, D. (1992). The health promoting school: closing the gap between theory and practice. Health Promotion International, 7(3), 151-153.

Oldenburg, B., Hardcastle, D. M., \& Kok, G. (1997). Diffusion of innovations. In Health behaviour and health education: theory, research and practice (pp. 270-286). San Fransisco: CA: Jossey-Bass.

Parsons, C., \& Stears, D. (2002). Evaluating health-promoting schools: steps to success. Health Education, 102(1), 7-15.

Parsons, C., Stears, D. \& Thomas, C. (1996) The Health Promoting School in Europe: conceptualising and evaluating the change. Health Education Journal, 55, 311-321.

Paulus P. From the health promoting school to the good and healthy school: new developments in Germany. In: Clift S, Jensen BB (eds). The Health Promoting School: International Advances in Theory, Evaluation and Practice. Copenhagen, Denmark: Danish University of Education Press, 2005, 55-74.

Paulussen, T., Wiefferink, K., \& Mesters, I. (2008). Invoering van effectief gebleken interventies. In Gezondheidsvoorlichting en gedragsverandering 2008. Een planmatige aanpak. (pp. 151-171).

Peters, L. W. H., \& Keijsers, F. E. M. (2002). Kwaliteitscriteria voor gezondheidsbevorderende interventies in en rondom scholen: review en checklistontwikkeling [Quality criteria for school health promotion interventions: review and checklist development]. Woerden: NIGZ - Centre for Review and Implementation.

Peters, L. W. H., Leurs, M. T. W., Jansen, M. W. J., Keijsers, J. F. E. M., \& Schaalma, H. P. (2004). Ontwikkeling van de schoolSlag checklist voor kwaliteit van schoolgerichte interventies [Development of the schoolBeat checklist for quality of school-based interventions]. Tijdschrift voor Gezondheidswetenschappen, 82(1), 50-57

Pijpers, F. I. M. (1999). Schoolgezondheidsbeleid in het basisonderwijs [School health policy in primary education]. Leiden University, Leiden.

Raudsepp, L., \& Vira, R. (2000). Sociocultural correlates of physical activity in adolescents. Pediatric Exercise Sience, 12, 51-60.

Resnick, M. D., Bearman, P. S., Blum, R. W., Bauman, K. E., Harris, K. M., Jones, J., en anderen (1997). Protecting Adolescents From Harm: Findings From the National Longitudinal Study on Adolescent Health. Journal of the American Medical Association, 278(10), 823-832.

Rogers, E. M. (1995). Diffusions of Innovations (4th ed.). New York: The Free Press.

Rogers, E. M. (2003). Diffusion of innovations (fifth edition ed.). New York: Simon \& Schuster, Inc. 
Ruland, E., Van Raak, A., Spreeuwenberg, C., \& Van Ree, J. (2003). Managing New Public Health: hoe zijn blijvende preventieve samenwerkingsverbanden te realiseren? Een agenda voor actie en onderzoek [How can preventive collaborations be realised? An agenda for action and research]. TSG, 81(1), 52-55.

Saan, H., \& De Haes, W. (2004). Een referentiekader voor gezondheidsbevordering. TSG Tijdschrift voor Gezondheidswetenschappen, 4, 208-211.

Sallis, J. F., McKenzie, T. L., Kolody, B., Lewis, M., Marshall, S., \& Rosengard, P. (1999). Effects of health-related physical education on academic achievement: project SPARK. Research Quarterly for Exercise and Sport, 70(2), 127-134.

Santos, M. P., Esculcus, C., \& Mota, J. (2004). The relationship between socioeconomic status and adolescents' organized and nonorganized physical activities. Pediatric Exercise Science 16, 210-218.

Schendel, J. (1965). Psychological differences between athletes and non-participants in atheletics at three educational levels. Research Quarterly, 36, 52-67.

Schurr, T., \& Brookover, W. (1970). Athletes, academic self-concept and achievement. Medicine \& Science in Sports \& Exercise, 2(2), 96-99.

Segers, J. H. G. (1983). Sociologische onderzoeksmethoden. Deel 1. Inleiding tot de structuur van het onderzoeksproces en tot de methoden van dataverzameling. Assen: Van Gorcum.

SHE. (2011). http://www.schoolsforhealth.eu/index.cfm.

Shediac, R. M. C., \& Bone, L. R. (1998). Planning for the sustainability of community-based health programs: conceptual frameworks and future directions for research, practice and policy. Health Education Research, 13(1), 87-108.

Shephard, R. J. (1996). Habitual physical activity and academic performance. Nutrition Reviews, $54(4$ Pt 2), S32-36.

Shilts, M. K., Horowitz, M., \& Townsend, M. S. (2009). Guided goal setting: effectiveness in a dietary and physical activity intervention with low-income adolescents. International Journal of Adolescent and Health, 21(1), 111-122.

Shilts, M. K., Lamp, C., Horowitz, M., \& Townsend, M. S. (2009). Pilot study: EatFit impacts sixth graders' academic performance on achievement of mathematics and english education standards. Journal of Nutrition Education and Behavior, 41(2), 127-131.

Simovska, V., en anderen (2010). HEPS Tool for Schools. Woerden, NIGZ. LO. (2007). Concretisering van de kerndoelen. Kerndoelen voor onderbouw VO. Enschede: Ministerie van OC\&W.

Smith, J. P. (2008) The impact of childhood health and adult labor market outcomes. Dublin, UCD Geary Institute (Labor and Population Working Papaer 14/2008).

St Leger, L. H. (1999) The opportunities and effectiveness of the health promoting primary school in improving child health - a review of the claims and evidence. Health Educ. Res., 14, 51-69. 10.1093/her/14.1.51. 
St. Leger, L., \& Nutbeam, D. (2000). Research into Health Promoting Schools. Journal of School Health, 70(6), 257.

St.Leger, L. (2004). What's the place of schools in promoting health? Are we too optimistic? Health Promotion International, 19(4), 405-408.

St.Leger, L. (2005a). Protocols and guidelines for health promoting schools. Promotion \& Education, XII(3-4), 145-147.

St.Leger, L. (2005b). Questioning sustainability in health promotion projects and programs. Health Promotion International, 20(4), 317-319.

St.Leger, L., \& Nutbeam, D. (1999). Evidence of effective health promotion in schools. In D. Boddy (Ed.), The evidence of health promotion effectiveness. Shaping public health in a new Europe. (pp. 110-122). Brussels: European Union.

St.Leger, L., \& Nutbeam, D. (2000). A model for mapping linkages between health and education agencies to improve school health. Journal of School Health, 70(2), 45-50.

Staatscourant. (2009). Convenant "Scholen voor primair en voortgezet onderwijs en sponsoring". In K. d. N. s. 1814 (Ed.) (Vol. 44, pp. 9). Den Haag.

Steward, D.E., Parker, E. \& Gillepsie, A. (2000) An audit of Health Promoting Schools policy documentation. Journal of School Health, 70, 253-254.

Stewart, D., (2008). Implementing Mental Health Promotion in Schools: A Proces Evaluation. International Journal of Mental Health Promotion, 10, 32-41.

Stewart-Brown, S. (2001). Evaluating health promotion in schools: reflections. In I. Rootman, M. Goodstadt, B. Hyndman, D. V. McQueen, L. Potvin, J. Springett \& E. Ziglio (Eds.), Evaluation in health promotion - principles and perspectives (pp. 272-284). Copenhagen: World Health Organization.

Stewart-Brown, S. (2006). What is the evidence on school health promotion in improving health or preventing disease and, specifically, what is the effectiveness of the health promoting schools approach? Copenhagen: WHO Regional Office for Europe

Suhrcke M, de Paz Nieves C (2011). The impact of health and health behaviours on educational outcomes in highincome countries: a review of the evidence. Copenhagen, WHO Regional Offi ce for Europe.

t Hart, H., Van Dijk, J., De Goede, M., Jansen, M. W., \& Teunissen, J. (1996). Onderzoeksmethoden. Amsterdam: Boom.

Tabor, J.; Beuhring, T.; Sieving, R. E.; Shew, M.; Ireland, M.; Bearinger, L. H. and Udry, J. R. (1997) Protecting Adolescents From Harm: Findings From the National Longitudinal Study on Adolescent Health. Journal of the American Medical Association, 278, 823-832. 10.1001/jama.1997.03550100049038.

Taras, H. (2005). Nutrition and student performance at school. Journal of School Health, 75(6), 199-213. 
Taras, H. (2005). Physical activity and student performance at school.Journal of School Health, 75(6), 214-218.

Teasdale, T. W., Sorensen, T. I., \& Stunkard, A. J. (1992). Intelligence and educational level in relation to body mass index of adult males. Human Biology, 64(1), 99-106.

Tijssen, I. M. J. G., Van Raak, A. J. A., Mur-Veeman, I. M., \& Maarse, J. A. M. (1992). Multiple-case studies. Enkeleproblemenbijdepraktijkvanhetonderzoeknaarzorgvernieuwingsprojecten [Multiple case studys. Some problems in the practise of care innovation research]. . Tijdschrif voor Gezondheidswetenschappen, 70(6), 337-344.

Trudeau, F., \& Shephard, R. J. (2008). Physical education, school physical activity, school sports and academic performance. International Journal of Behavioral Nutrition and Physical Activity, 5, 10.

Trudeau, F., \& Shephard, R. J. (2010). Relationships of Physical Activity to Brain Health and the Academic Performance of Schoolchildren. American Journal of Lifestyle Medicine, 4, 138-150.

Turkenburg, M. (2008). De school bestuurd. Schoolbesturen over goed bestuur en de maatschappelijke opdracht van de school. Den Haag: Sociaal en Cultureel Planbureau.

Van der Steenhoven, P., \& Van Veen, D. (2009). NJi-monitor. Leerlingenzorg en zorg- en adviesteams in het voortgezet onderwijs 2008. Utrecht: Nederlands Jeugd Instituut.

Van Dijk, J. P., Groothoff, J. W., Herweijer, M., \& Post, D. (2003). Omvang van het gemeentelijk gezondheidsbeleid. Tijdschrift voor Gezondheidswetenschappen, 81(2), 103-107.

Van Raak, A., Mur-Veeman, I., Hardy, B., Steenbergen, M., \& Paulus, A. (2003). Integrated Care in Europe. Description and comparison of integrated care in six EU countries (1st ed.). Maarssen: Elsevier.

Verdurmen, J., Van Oort, M., Meeuwissen, J., Ketelaars, T., De Graaf, I., Cuijpers, P., en anderen (2003). Effectiviteit van preventieve interventies gericht op jeugdigen: de stand van zaken [Effectivenes of preventive activities targetting youth: state of the art]. Utrecht: Trimbosinstituut.

Vernez G, K. R., Rydell CP. . (1999). The public benefits of education. In

Closing the Education Gap: Benefits and Costs (pp. 13-32). Santa Monica: CA: RAND Corporation.

VNG, GGD Nederland, \& NIGZ. (2003). Pleidooi voor extra investeren in gezonde jeugd.

VO-raad, \& Ministerie van OC\&W. (2008). Kwaliteitsagenda Voortgezet Onderwijs. Teken voor kwaliteit. Afspraken voor een beter voortgezet onderwijs 2008-2011: V0-raad Ministerie OCW.

VO-raad. (2009). Ambitie aan zet! Jaarverslag voortgezet onderwijs 2008/2009. Utrecht: VOraad.

WHO (1996) Improving School Health Programmes: Barriers and Strategies. The School Health Working Group. The WHO Expert Committee on Comprehensive School Health Education and Promotion. Geneva. 
WHO Regional Office for Europe (1996) Regional Guidelines: development of health-promoting schools: aframework for action. Manila, WHO Regional Office for Western Pacific.

WHO. (1986). Ottawa Charter for Health Promotion. Copenhagen: WHO Regional Office for Europe.

WHO. (2006). What is the evidence on school health promotion in improving health or preventing disease and, specifically, what is the effectiveness of the health promoting schools approach? Copenhagen: WHO.

Wijsmuller, M. (2002). Zorgstructuur rond het onderwijs. Problemen eerder signaleren en adequater oppakken. Spectrum Actueel, 4, 10.

Yin, R.K. (2009). Case Study Research: Design and Methods (4th Ed.). Thousans Oaks, Cal.: Sage.

Zins, J. E., Weissberg, R. P., Wang, M. C., \& Walberg, H. J. (2004). Building academic success on social and emotional learning. New York: Teachers College Press.

ZonMw. (2006). The effectiveness of implementation strategies for integrated school health promotion based on DISC-analyses (pp. 27). Universiteit Maastricht, GGD Zuid Limburg \& NIGZ. 



\section{Summary}

Since research has shown that healthy students perform better than unhealthy ones, one might expect that the educational system would give systematic attention to their students' health. Unfortunately, this is not necessarily always the case. There are no Dutch laws or regulations that oblige schools to engage in heath promotion. Although schools do feel responsible for this issue, the pressure of time they are under often results in health policy being given low priority.

In an attempt to strengthen the position of health promotion in Dutch schools, the Schoolslag (literally 'school beat') approach was introduced in 2001. This is a method to assist schools in the development and implementation of a systematic school health policy. Since the development and introduction of this approach, much practical experience has been gained with the approach, and this situation was the point of departure for the research project reported on in this thesis, which centred on the following general research question:

"How can the Schoolslag approach contribute to the systematic embedding of health promotion in the school setting?"

The various chapters of this thesis provide answers to specific questions derived from this general research question. The Introduction chapter outlines the context within which the studies were carried out. It describes the Schoolslag approach, as well as the way the educational system and health promotion are organized in the Netherlands. The first part of the thesis (Chapter 1) reports on a study of the literature on the most relevant research into the relation between health promotion activities and the way children perform at school. Part 2 (Chapter 2) outlines the current situation with regard to school health policies in the Netherlands. Part 3 (Chapters 3 , 4,5 and 6) reports on our studies into the implementation of the Schoolslag method in the Southern Limburg region of the Netherlands. Finally, the General Discussion (Chapter 7) reflects on the findings of the various studies. It also translates the research findings for use in routine practice and offers recommendations for the future. The content of each of the chapters is summarized below.

The Introduction starts by describing the original reason for developing school health policies. On the whole, health promotion cannot be said to have gained a permanent position within the Dutch educational system. The position of school health policies is somewhere between the legislative spheres of the Ministry of Health, Welfare and Sport and the Ministry of Education, Culture and 
Science. Since Dutch legislation does not link health and education, such a link is also lacking in the way these two fields are organized. Although schools feel responsible for their students' health, they have limited resources available to promote it. The Schoolslag approach was designed to strengthen this position. The Introduction ends by presenting the general research question, the specific questions derived from it and an outline of the contents of the thesis.

Part 1, Chapter 1, reports on a review of the literature on the most relevant investigations into the relation between health promotion activities and students' academic performance. The chapter draws the conclusion that there is evidence, albeit inconsistent, for favourable effects of such activities on academic performance, although negative effects have also been reported.

Chapter 2 outlines the current situation with regard to school health policies in the Netherlands. Although the number of regional health authorities that assist schools in developing their health policy is growing, there are differences between the various regions in the way this is done. The chapter focuses on the reasons for assisting schools in introducing health policies, as well as on the various activities undertaken by these health authorities to assist schools, the experiences gained with these activities and the preferences for further assistance. It concludes that many regional health authorities are assisting schools in one way or another in the development of school health policies. It also claims, however, that the position of school health policies in the educational system could be further strengthened by efforts to improve the role of such policies within schools, within the organizational structure of the regional health authorities and within the national educational and health frameworks. The competencies of staff at regional health authorities as regards building constructive links between the authorities and schools and establishing local collaborative structures also need to be improved.

The implementation of the Schoolslag approach in the Southern Limburg region is the subject of the next four chapters (Part 3).

Chapter 3 describes the current situation as regards school health policies in secondary schools in Southern Limburg, and the barriers and facilitators of the implementation process. The study found that the introduction of such policies is as yet less than optimal. Causes that are reported include pressure of work, the fact that health promotion is not a compulsory task of schools, as well as causes relating to the Schoolslag approach itself, although schools do feel responsible for their students' health. The chapter concludes that the Schoolslag approach can offer valuable assistance to schools in developing and implementing health policies, provided it takes the possibilities and limitations of the educational system into account. 
Chapter 4 focuses on the assistance provided by the Schoolslag advisors. The key question is whether the assistance offered by these advisors contributes to the implementation of the Schoolslag approach and whether schools are pleased with the assistance offered. The level of satisfaction was assessed by evaluating two aspects: the assistance offered in completing the steps in the Schoolslag implementation process, and the competencies of the Schoolslag advisors. The findings show that schools were pleased with both aspects of the assistance offered. They also show that those schools that did implement the Schoolslag approach lor at least partly) were more satisfied with the assistance offered by the advisors than schools that had not done so. Employing personal advisors to assist schools in the introduction of school health policies can indeed contribute to the implementation of such policies.

Chapter 5 investigates in more detail the way in which the Schoolslag advisor can influence the process of implementing school health policies. This was examined by means of a comparison between the school that had made the greatest progress in introducing a school health policy and the school that had made the least progress. The findings were used to assess what factors could explain the difference between the two schools. Both schools were evaluated on the basis of the same aspects: external factors, change management, context, project management and collaboration. The findings show that the organizational context at the two schools differed in terms of change management, project management and collaboration. The chapter concludes that attention must be given not only to the actual introduction of the steps of the Schoolslag method, but also to organizational issues. Treating the introduction of a school health policy as an organizational change can promote the implementation process. This does, however, require the Schoolslag advisor to possess certain specific competences.

Chapter 6 introduces the Schoolslag Checklist, a measurement instrument that the Schoolslag advisors use to select the right strategy for the chosen priority. It differentiates between factors affecting the effectiveness and factors affecting the compatibility of the Schoolslag approach with the teaching programme. This chapter reports on a study into the validity, reliability and suitability of the instrument. Reliability and suitability were examined by asking 29 teachers and 25 health promotion/prevention officers to assess four existing prevention programmes using the checklist. The Schoolslag Checklist was assessed as valuable by $73 \%$ of the respondents and as easy to interpret by $65 \%$. The results of reliability analyses showed that the instrument has acceptable to high internal consistency, with Cronbach's alphas ranging from 0.64 to 0.92 . The chapter concludes that version 1.2 of the Schoolslag Checklist is an internally consistent and useful instrument to determine the quality of school interventions. Further research will be needed, however, to accurately assess the instrument's validity. 
The thesis ends with the Conclusion chapter, which summarizes the main findings and places them in a wider context. The chapter concludes by advocating the use of school health policies. Although much effort has been invested in school health policies in recent years, at both national and regional levels, there is still much work to be done. Successful implementation of school health policies demands continued investments in research, teaching and national and regional policymaking. 


\section{Samenvatting}

Uit onderzoek is bekend dat gezonde leerlingen beter presteren dan ongezonde leerlingen. Op basis van dit gegeven zou je verwachten dat binnen het onderwijs structureel aandacht wordt gegeven aan gezondheid. Helaas is dit geen vanzelfsprekendheid. Vanuit de wet en regelgeving zijn geen verplichtingen opgenomen ten aanzien van gezondheid binnen het onderwijs. Scholen voelen zich wel verantwoordelijk maar door de grote tijdsdruk die ze ervaren verdwijnt gezondheid vaak naar een lage plaats op de prioriteitenlijst.

Om de positie van gezondheid binnen het onderwijs te versterken is in 2001 de schoolslagwerkwijze ontwikkeld. Een werkwijze om scholen te begeleiden bij de ontwikkeling en implementatie van structureel schoolgezondheidsbeleid. Sinds de ontwikkeling en invoering in 2001 is veel ervaring opgedaan met de werkwijze in de praktijk. Deze situatie vormt het uitgangspunt voor het beschreven onderzoek. Binnen het onderzoek stond de volgende onderzoeksvraag centraal:

"Hoe kan de schoolslag-werkwijze bijdragen aan het structureel inbedden van gezondheidsbevordering in de setting school?"

In de verschillende hoofdstukken zijn deelvragen van het onderzoek centraal gesteld en beantwoord. In de inleiding wordt een kader geschetst waarbinnen het onderzoek is uitgevoerd. Naast een beschrijving van de schoolslag-werkwijze wordt een overzicht gegeven van de organisatie van het onderwijs en van gezondheidsbevordering in Nederland. Het eerste deel van het proefschrift (hoofdstuk 1) beschrijft de wetenschappelijke onderbouwing voor schoolgezondheidsbeleid. In deel 2 (hoofdstuk 2) wordt een overzicht gegeven van de huidige positie van schoolgezondheidsbeleid in Nederland. Deel 3 (hoofdstuk, 3, 4, 5, 6) beschrijft de deelonderzoeken die zijn uitgevoerd naar de implementatie van de schoolslag-werkwijze in Zuid-Limburg. In de discussie wordt een reflectie gegeven op de beschreven onderzoekresultaten. Daarnaast worden de onderzoeksresultaten vertaald naar de praktijk van alledag en worden aanbevelingen gegeven voor de toekomst. Hieronder volgt een nadere samenvatting van de verschillende hoofdstukken.

De inleiding begint met de aanleiding voor de ontwikkeling van schoolgezondheidsbeleid. Samenvattend kan gesteld worden dat gezondheidsbevordering nog geen vaste plek heeft verworven binnen de structuur van het onderwijs. Schoolgezondheidsbeleid bevindt zich tussen de wetgeving van het Ministerie van Volksgezondheid Welzijn en Sport (VWS) en het Ministerie 
van Onderwijs Cultuur en Wetenschap (OC\&W). Doordat in de wetgeving geen link wordt gelegd tussen gezondheid en onderwijs is deze link ook in de organisatie van beide terreinen niet terug te vinden. Scholen voelen zich verantwoordelijk voor de gezondheid van hun leerlingen, maar hebben slechts beperkte middelen om de gezondheid van hun leerlingen te bevorderen. De schoolslag-werkwijze is ontwikkeld om deze positie te versterken. De inleiding sluit af met een beschrijving van de centrale onderzoeksvraag, de bijbehorende deelvragen en een leeswijzer voor dit proefschrift.

In deel 1, hoofdstuk 1 wordt middels een literatuuronderzoek een overzicht gegeven van de belangrijkste onderzoeken die zijn uitgevoerd gericht op de relatie tussen gezondheid bevorderende activiteiten en leerprestaties. Dit hoofdstuk eindigd met de conclusie dat op basis van verschillende onderzoeken gesteld kan worden dat er bewijs bestaat voor mogelijke effecten van onderdelen van gezondheid bevorderende activiteiten op de leerprestaties van leerlingen.

Hoofdstuk 2 geeft een overzicht van de huidige positie van schoolgezondheidsbeleid in Nederland. Steeds meer GGD'en ondersteunen scholen bij de vormgeving van schoolgezondheidsbeleid. De wijze waarop dit gebeurt, verschilt echter per regio. In dit hoofdstuk wordt de nadruk gelegd op de aanleiding om scholen te begeleiden bij de invoering van schoolgezondheidsbeleid, de verschillende activiteiten die GGD'en uitvoeren om scholen te ondersteunen, hun ervaringen hiermee en de wensen voor ondersteuning. Geconcludeerd kan worden dat veel GGD'en op enige manier scholen begeleiden bij de vormgeving van schoolgezondheidsbeleid. De positie van schoolgezondheidsbeleid binnen het onderwijs zou echter nog verder versterkt kunnen worden door meer aandacht te besteden aan de positionering van schoolgezondheidsbeleid op schoolniveau, binnen de organisatie van de GGD, maar ook binnen de landelijke kaders van onderwijs en gezondheid. Ook de competenties van GGD-medewerkers ten aanzien van het leggen van constructieve verbindingen tussen de GGD en scholen, en het creëren van lokale samenwerking, vragen om aandacht.

De implementatie van de schoolslag-werkwijze in Zuid-Limburg wordt in vier verschillende hoofdstukken beschreven (deel3).

Hoofdstuk 3 beschrijft in hoeverre sprake is van schoolgezondheidsbeleid in het voortgezet onderwijs in Zuid-Limburg en welke factoren bevorderend dan wel belemmerend werken bij dit implementatieproces. De invoering van schoolgezondheidsbeleid blijkt nog niet optimaal te zijn. Redenen als hoge werkdruk, ontbreken van gezondheidsbevordering als verplichting in de kerndoelen, maar ook redenen gerelateerd aan de schoolslag-werkwijze worden genoemd. Wel voelen scholen zich verantwoordelijkheid voor de gezondheid van hun leerlingen. Geconcludeerd 
wordt dat, wanneer meer rekening wordt gehouden met de (on)mogelijkheden binnen het onderwijs, de schoolslagwerkwijze een goede vorm van begeleiding voor het onderwijs kan zijn bij het ontwikkelen en uitvoeren van schoolgezondheidsbeleid.

In hoofdstuk 4 staat de begeleiding van de schoolslag-adviseur centraal. De centrale vraag is of de begeleiding van de schoolslag-adviseur positief bijdraagt aan de implementatie van de schoolslag-werkwijze en of de scholen daar tevreden over zijn. Voor het meten van de tevredenheid van de school is onderscheid gemaakt in twee aspecten: de begeleiding bij het uitvoeren van de schoolslag-stappen en de competenties van de schoolslag-adviseur. De resultaten tonen aan dat scholen voor beide aspecten tevreden zijn over de begeleiding van de schoolslag-adviseur. Bovendien blijken scholen die de schooslag-werkwijze (gedeeltelijk) geïmplementeerd hebben tevredener over de begeleiding van de schoolslag-adviseur dan scholen die dit niet gedaan hebben. Het inzetten van een persoonlijke begeleider voor scholen bij de invoering van schoolgezondheidsbeleid kan een positieve bijdrage leveren aan de implementatie van schoolgezondheidsbeleid.

In hoofdstuk 5 wordt een stap verder gegaan door dieper in te gaan op de wijze waarop de schoolslag-adviseur van invloed kan zijn op de implementatie van schoolgezondheidsbeleid. Voor dit onderzoek is een case-studie uitgevoerd voor de school die het verst is met de invoering van schoolgezondheidsbeleid en de school die het minst ver is met de invoering van schoolgezondheidsbeleid. Op basis van de onderzoeksgegevens is bekeken welke factoren bepalend kunnen zijn voor het verschil. Voor beide scholen zijn dezelfde factoren beoordeeld: externe factoren, verander management, context, projectmanagement en samenwerking. Op basis van de resultaten kan gesteld worden dat de organisatie van beide scholen verschilde voor verandermanagement, projectmanagement en samenwerking. Dit hoofdstuk eindigt met de conclusie dat naast de daadwerkelijke invoering van het schoolslag-stappenplan ook de organisatorische aspecten aandacht verdienen. Wanneer de invoering van schoolgezondheidsbeleid benaderd wordt als een organisatorische verandering zal dit een positieve bijdrage leveren aan het implementatieproces. Dit vraagt echter wel om specifieke competenties van de schoolslag-adviseur.

In hoofdstuk 6 wordt de schoolslag-checklist geïntroduceerd, een meetinstrument dat schoolslag-adviseurs gebruiken bij de selectie van de juiste strategie bij de gekozen prioriteit. Er wordt een verschil gemaakt tussen factoren gericht op effectiviteit en factoren gericht op toepasbaarheid binnen het onderwijs. In dit hoofdstuk wordt een beschrijving gegeven van een onderzoek naar de validiteit, betrouwbaarheid en bruikbaarheid van het meetinstrument. Voor het bepalen van betrouwbaarheid en bruikbaarheid hebben 29 onderwijsgevenden en 25 GVO/ 
preventiefunctionarissen vier bestaande preventieprogramma's beoordeeld met de checklist. De schoolslag-checklist werd door $73 \%$ van de respondenten als waardevol en door $65 \%$ als duidelijk beoordeeld. Betrouwbaarheidsanalyses tonen een aanvaardbare tot hoge interne consistentie, met Cronbach's alpha's variërend van 0,64 tot 0,92. Hoofdstuk 6 eindigt met de conclusie dat de schoolslag-checklist 1.2 een intern consistent en bruikbaar instrument is voor het bepalen van de kwaliteit van schoolse interventies. Echter, om nauwkeurige uitspraken te kunnen doen over de validiteit van het meetinstrument is nader onderzoek gewenst.

Dit proefschrift wordt afgesloten met de discussie waarin de belangrijkste resultaten worden samengevat en in een bredere context worden geplaatst. Dit hoofdstuk eindigt met een lobby voor schoolgezondheidsbeleid. Afgelopen jaar is zowel op landelijk niveau als op regionaal niveau veel geïnvesteerd in schoolgezondheidsbeleid. Toch zijn we nog niet klaar. Succesvolle implementatie van schoolgezondheidsbeleid vraagt om voortdurende investeringen, zowel op het gebied van onderzoek, onderwijs als in de landelijke en regionale politiek. 


\section{Dankwoord}

\section{"Zekerheid is niet de bedoeling van het leven. Grote uitdagingen zijn het risico waard."}

En een uitdaging, dat was het de afgelopen vier jaar. Vanuit een baan in de wereld van de praktijk de kans krijgen om te promoveren in de wereld van de wetenschap, het onderzoek. Een onbekende weg. Na een periode van voorbereiden zijn we in januari 2007 gestart aan een nieuwe uitdaging die vier en een half jaar zou duren. Een uitdaging waarin ik mijn zekerheden moest loslaten en terecht kwam in een wereld waarin niets vast leek te liggen en niets zeker leek te zijn. Een grote uitdaging die meer dan welkom was maar die ik nooit alleen aan had kunnen gaan. Daarom wil ik op deze plek een aantal mensen persoonlijk bedanken voor de bijdrage die ze hebben geleverd aan deze uitdaging:

\section{De beslissing}

Het begin van deze stap had ik niet gezet zonder de stimulerende woorden van Mariken (Mariken Leurs, destijds coördinator schoolslag. Nu programma hoofd Centrum Gezond Leven- RIVM), je was een groot voorbeeld voor mij toen ik als groentje bij de GGD binnen kwam. Veel bewondering had ik voor de wijze waarop jij, je functie als coördinator schoolslag met je promotieonderzoek en je gezin combineerde. Nooit hield ik voor ogen dat ik na jouw vertrek het stokje van het promotieonderzoek van je over zou nemen. Dankjewel voor het vertrouwen dat je me gaf.

\section{Mijn begeleidingsteam}

Nanne (Prof. Dr. N.K. de Vries), bedankt voor alles. Je wist me te inspireren en zorgde ervoor dat ik tot het uiterste ging. Door jouw stimulerende begeleiding lukte het me een goede balans te vinden tussen praktijkwerk en onderzoek. Je gaf me de kans om binnen het werk in de praktijk nieuwe uitdagingen te pakken maar ondanks dat het onderzoek niet uit het oog te verliezen. Het is je gelukt me los te weken uit de praktijk (zelf van de wollige ambtenaar taal) en me de meerwaarde van onderzoek in de praktijk te laten waarderen. Ik weet zeker dat we deze combinatie nog vaak binnen ons werkveld zullen inzetten. Bedankt!

Bert (Bert Hesdahl, afdelingshoofd afdeling gezondheidsbevordering GGD Zuid Limburg), bedankt voor je vertrouwen. Je gaf me de gelegenheid afstand te nemen van de praktijk. Maar door jouw betrokkenheid en manier van begeleiding bleef ik toch het gevoel houden onderdeel 
uit te maken van het team. Je open blik op het onderzoek zorgde voor een goede balans tussen de wetenschappelijke waarde van het onderzoek en het nut voor de praktijk. Ik heb er dan ook alle vertrouwen in dat deze balans ook in de toekomst een belangrijke plek binnen ons werk zal blijven innemen.

Patricia (Patricia van Assema) bedankt voor het uitvoeren van de eindredactie voor mijn eerste publicaties. Veel heb ik geleerd van de overleggen met jou. Met goede tips wist je mij te motiveren om het hele artikel qua structuur om te draaien maar hierdoor de kwaliteit van het artikel met sprongen te vergroten. Bedankt!

Maria (Maria Jansen, coördinator academische werkplaats) bedankt voor al je inzet en begeleiding bij de afronding van mijn proefschrift. Door jouw bevlogenheid lukte het om in korte tijd de omlijsting van het proefschrift op papier te zetten. Mede door jou kritische blik is het gelukt het beste uit mezelf naar boven te halen. Bedankt!

\section{De vertaling naar de praktijk}

Een belangrijk doel van dit onderzoek was dat het een meerwaarde zou vormen voor de praktijk. Deze omslag had ik niet kunnen maken zonder de inzet van, met name, twee personen: Bert (Bert Hesdahl, afdelingshoofd afdeling gezondheidsbevordering GGD Zuid Limburg), ja naast de begeleiding heb je ook in de praktijk veel werk voor mijn onderzoek verzet. Judith (Judith Aerdts, coördinator schoolslag), bedankt dat ik de mogelijkheid heb gekregen om de praktijk als proeftuin te gebruiken voor mijn onderzoek. Bert en Judith, met plezier kijk ik terug op onze brainstormmomenten tijdens de regiegroep om de vertaalslag van onderzoek naar praktijk concreet te maken. Bedankt voor jullie inzet. Ik realiseer me dat ik veel van jullie heb gevraagd om tussen de toch al drukke werkzaamheden door ook nog werkzaamheden voor mijn onderzoek te moeten verrichten. Toch hebben jullie je voor $200 \%$ ingezet o.a. tijdens de gesprekken met alle school directies waarin de resultaten van mijn onderzoek werden teruggekoppeld maar waarin jullie ook nog een dubbele opdracht kregen om extra onderzoeksgegevens voor mij te verzamelen. Ik ben erg blij dat het onderzoek een bijdrage heeft kunnen leveren aan de versterking van de schoolslag-werkwijze in Zuid-Limburg.

\section{De hulp}

Het onderzoek had ik niet kunnen uitvoeren zonder de inzet van een grote groep mensen. Patricia (Patricia Senden, onderzoeksassistent 2e jaar, schoolslag-adviseur) dankjewel voor je onmisbare hulp bij de data verzameling van mijn onderzoek. Zonder jouw inzet als onderzoeksassistent had het veel langer geduurd om de respons zo hoog te krijgen. 
Monique, (Monique Janssen, onderzoeksassistent 3e-4e jaar). Dankjewel dat je alle tijdrovende klussen van me over kon nemen zodat ik me kon richten op het schrijven van mijn proefschrift. Alle schoolslag-adviseurs voor jullie inzet bij de verspreiding en het zelf invullen van de vragenlijsten, bedankt.

Alle zorgcoördinatoren en schoolslag-contactpersonen binnen de scholen, bedankt voor jullie bijdrage aan het onderzoek en voor jullie reclame voor het onderzoek bij de collega's. Alle managers en docenten binnen de scholen die hebben deelgenomen bedankt dat jullie je kennis en ervaring met mij wilde delen.

Marja Vissers, Leon Kolenburg, Mirjam Bergmans, Ingrid Hennen en Marianne Quaedvlieg, bedankt voor jullie hulp en ondersteuning bij de randvoorwaardelijke zaken zoals ICT, secretariële ondersteuning en communicatie. Zonder jullie had het eindresultaat nu niet voor jullie gelegen.

\section{De uitwisseling}

Katharina (Katharina Pucher, promovendus DISC-onderzoek), in onze samenwerking hebben we uren gebrainstormd over de samenwerking bij het opstellen van schoolgezondheidsbeleid. De ervaringen die we op deden bij de andere regio's leerde me met een open blik naar de praktijk in Zuid-Limburg te kijken. Er zijn meer wegen die naar Rome leiden en het is aan ons om die te kiezen die het meest past bij de eigenschappen van de betrokkenen.

\section{De afleiding}

Dit proces had ik niet kunnen doorlopen zonder de afleiding van alle collega's bij de GGD en de universiteit bedankt voor de gezellige pauzes, de hulp, de belangstelling, de afleiding, de kennis, en er zijn vast nog dingen die ik vergeet. Zonder jullie was het werk veel minder leuk geweest.

\section{De Academische Werkplaats}

Maria, (Maria Jansen, coördinator academische werkplaats) ons vangnet binnen de Academische Werkplaats. Het is altijd prettig om te weten dat er iemand is waar je op terug kunt vallen bij problemen. Bedankt!

Anita Vermeer, Mieke Steenbakkers en alle anderen. Mijn promotiemaatjes binnen de Academische Werkplaats. Bedankt dat we dit proces samen konden doorlopen. Ik kijk met plezier terug naar onze klets- en klaaguurtjes die je, hoe raar ook, toch weer energie geven om verder te gaan. 


\section{Mijn paranimfen}

Christianne Hardy en Judith Aerdts, wie kon ik anders vragen om deze bijzondere rol te vervullen op zo'n speciale dag voor schoolslag. Christianne, jij hebt aan de wieg gestaan van schoolslag en bent voortdurend kritisch gebleven over datgene dat we nastreven. Dit hielp mijn om alles van het onderzoek steeds weer in perspectief te plaatsten. Judith jij hebt tijdens mijn promotieperiode de touwtjes in handen gehad van de doorontwikkeling van de werkwijze. Door onze samenwerking hebben we het onderzoek zo kunnen uitvoeren dat het ook daadwerkelijk onderdeel uitmaakte van de dagelijkse praktijk. Beide dragen jullie schoolslag dagelijks uit, een betere steun kan ik me niet wensen. Dankjewel dat jullie aan mijn zijde willen staan.

\section{Mijn thuisfront}

Papa en mama, mijn ouders, bedankt dat jullie trots op me zijn.

Cécile, mijn zus, dankjewel voor je kritische wetenschappelijke blik op de concept versies van mijn publicaties. En natuurlijk voor de afleiding, ontspanning en het luisterend oor.

Alle familie en vrienden, zonder dat jullie het in de gaten hadden hebben jullie ervoor gezorgd dat ik in mijn vrije tijd helemaal los kon komen van mijn onderzoek zodat ik daarna weer fris aan de slag kon.

\section{Mijn trots}

En tot slot Stephan, mijn man en steun en toeverlaat, dankjewel dat je de hectiek van het werk altijd weer wist te relativeren. Wat is nu echt belangrijk in het leven. Voor alles is een oplossing en een weekend ontspannen doet wonderen. Deze luchtige blik zorgde ervoor dat het schrijven van mijn proefschrift werk bleef.

En dan als allerlaatste natuurlijk onze kleine Valentijn, jij zorgt ervoor dat de laatste paar maanden een nog grotere uitdaging werden, en de volgende uitdaging alweer voor me klaar staat.

\section{"Zekerheid is niet de bedoeling van het leven. Deze uitdagingen was het risico meer dan waard.}




\section{Curriculum Vitae}

Nicole Boot werd geboren op 11 september 1979 in Maastricht - Nederland. Na het behalen van haar HAVO diploma aan het Trichter College te Maastricht in 1997 begon ze aan een HBOopleiding tot verpleegkundige aan de Hoge School Zuyd. In 2001 ronde ze deze opleiding met succes af.

In september 2001 startte ze de opleiding gezondheidswetenschappen met als afstudeerrichting gezondheidsvoorlichting aan de Universiteit Maastricht. Als afstudeerstage deed ze bij GGD Zuid Limburg (voorheen GGD Zuidelijk Zuid-Limburg) onderzoek naar de betrouwbaarheid, validiteit en bruikbaarheid van de schoolslag-checklist. Een meetinstrument voor preventieprogramma's gericht op het onderwijs (N. M. W. M. Boot en anderen, 2005) (Begeleider: Prof. Dr. N.K. de Vries en Prof. Dr. H.P. Schaalma). In 2003 behaalde ze haar diploma.

In augustus 2003 begon ze als GVO-functionaris jeugd jongeren bij GGD Zuid Limburg lvoorheen GGD Zuidelijk Zuid-Limburg). Binnen deze functie lag de nadruk van haar werkzaamheden op genotmiddelenpreventie en had ze als schoolslag-adviseur de taak scholen te begeleiden bij de invoering van schoolgezondheidsbeleid met behulp van de schoolslag-werkwijze. Naast haar praktijkwerkzaamheden bij de GGD heeft ze, van mei 2004 tot januari 2006, Mariken Leurs, als onderzoeksassistent, begeleid bij haar promotieonderzoek gericht op de ontwikkeling van de schoolslag-werkwijze (M. Leurs, 2008).

Deze ervaringen inspireerde haar om in januari 2007 zelf te starten als promovendus binnen de Academische Werkplaats Publieke Gezondheid Limburg. Binnen deze opleidingsplaats werkte ze vijftig procent van haar tijd aan het onderzoek dat in dit proefschrift beschreven is.

In december 2007 startte ze, naast haar promotieonderzoek, als landelijke implementatieadviseur binnen het DISC-project. Een onderzoeksproject waarin 6 GGD regio's in Nederland worden begeleid en gevolgd bij het opzetten van een samenwerkingsstructuur en de invoering van schoolgezondheidsbeleid middels de principes van de schoolslag-werkwijze. Naast het adviseren van GGD regio's heeft ze ook werkzaamheden verricht voor het RIVM - Centrum Gezond Leven. Hier heeft ze een bijdrage geleverd aan hun opdracht om de Gezonde School Methode (landelijke benaming voor de schoolslag-werkwijze) door te ontwikkelen en landelijk uit te dragen. In 2008 heeft ze zitting gehad in twee werkgroepen gericht op de landelijke doorontwikkeling en evaluatie van de Gezonde School Methode binnen Centrum Gezond Leven. 
Sinds 2009 bestaat er een intensieve samenwerking met Centrum Gezond Leven. Binnen deze samenwerking is een bijdrage geleverd aan de landelijke handleiding van de Gezonde School Methode voor GGD'en. In het kader van deze samenwerking is de publicatie in dit proefschrift gericht op de landelijke ontwikkelingen gerealiseerd. Naast bovenbeschreven werkzaamheden is ze betrokken geweest bij doorontwikkeling van de schoolslag-werkwijze binnen GGD Zuid Limburg. De koppeling van de onderzoeksgegevens met de beleidsmatige plannen en mogelijkheden binnen de praktijk vormden hiervoor de basis.

$\mathrm{Na}$ het afronden van het promotie onderzoek is Nicole Boot gestart als projectleider van een nieuw door ZonMw gefinancierd project gericht op het promoten van bewegen bij kinderen van groep 7 en 8 van het basisonderwijs. Het project is nauw verbonden met de implementatie van de schoolslag-werkwijze in het basisonderwijs. Binnen dit project kan de ervaringen en kennis van het uitgevoerde onderzoek optimaal worden benut in de praktijk. 


\section{Publicatie overzicht}

2003

Boot, N.M.W.M. (2003). Schoolslag-checklist 1.2 - een onderzoek naar de validiteit, betrouwbaarheid en bruikbaarheid. Faculteit der Gezondheidswetenschappen. Maastricht University, Maastricht.

\section{4}

Boot, N.M.W.M., Leurs, M.T.W., et al. “Kwaliteitscriteria voor schoolse interventies gericht op collectieve gezondheidsbevordering en preventie: de schoolSlag-checklist collectieve gezondheidsbevordering en preventie: de schoolSlag-checklist 1.2." Lezing tijdens Nederlands Congres Volksgezondheid. 2004.

\section{5}

Boot, N.M.W.M., Leurs, M.T.W., et al. (2005). “Evaluatie van de schoolSlag-checklist gericht op het beoordelen van de kwaliteit van schoolse interventies [Evaluation of the schoolBeat-checklist assessing the quality of school-based interventions]." Tijdschrift voor Gezondheidswetenschappen 83(7): 405-411.

Boot, N. (2005). Evaluatie van de leerlingrapportages Veilige School [Evaluation pupil reports Safe School]. Maastricht, Maastricht Public Health Institute.

Boot, N., Bouts, M. (2005). Mogelijkheden in het VO \& introductie genotmiddelen protocol. Studiedag genotmiddelenpreventie (drugprevention training), Maastricht. Maastricht.

Boot, N.M.W.M., Bessems, K., et al. (2005). Het schoolslag aanbod 2005-2006. Mogelijkheden op het gebied van gezondheid en onderwijs in de regio Maastricht-Mergelland. Woerden / Maastricht, NIGZ / Maastricht Public Health Institute.

\section{6}

Boot, N., De Ruiter, S. (2006). Schoolslag inventarisatie 2006-2007; Mogelijkheden op het gebied van gezondheid en onderwijs in de regio Maastricht-Mergelland. Woerden / Geleen, NIGZ / GGD Zuidelijk Zuid Limburg.

Boot, N.M.W.M., Leurs, M.T.W.M., et al. (2006). Prioriteiten bij Gezondheidsbevordering en preventieactiviteiten in het voortgezet onderwijs (lezing). In Nederlands Congres Volksgezondheid [Dutch Public Health Conference]. Rotterdam. 
Boot, N. (2006). Evaluatie leerlingrapportages Limburgse jeugdmonitor 2005 [Evaluation pupil reports Limburgse Jeugdmonitor 2005]. Maastricht, Maastricht Public Health Institute.

2007

Boot, N. (2007). Onderzoeksvoorstel Scholen in Dialoog met data; Inbedding van de schoolslagwerkwijze. Maastricht, Academische Werkplaats Publieke Gezondheid.

Husslage, B. (2007). “SchoolSlag stimuleert, coördineert en meet. Interview met Nicole Boot." Special Jeugd Mediator ZonMw 18(8).

\section{8}

Boot, N., Buijs, G., et al. (2008). De Gezonde School in Nederland: stand van zaken. Bilthoven, Centrum Gezond Leven - RIVM.

\section{9}

Pucher, K.K., Boot, N.M.W.M., et al. The Dlagnosis of Sustainable Collaboration model; a guide for sustainable collaboration in school health policies? (lecture). In Third European Conference on Health Promoting Schools: Better Schools through Health. Vilnius (Lithuania). 2009.

Boot, N.M.W.M., Hesdahl, B., et al. Health promotion in secondary schools: arranged marriage or true love? (lecture). In Third European Conference on Health Promoting Schools: Better Schools through Health. Vilnius (Lithuania). 2009.

Boot, N.M.W.M.. Gezondheidsbevordering in beweging: De schoolslag-werkwijze als voorbeeld van professionalisering (lezing). In 6e Nationale Congres Gezondheidsbevordering en Preventie. Amersfoort. 2009.

Boot, N.M.W.M., Hesdahl, B., et al. Gezondheidsbevordering \& voortgezet onderwijs: verstandshuwelijk of echte liefde? (lezing). In Nederlands Congres Volksgezondheid [Dutch Public Health Conference]. Rotterdam. 2009.

Boot, N.M.W.M., Hesdahl, B., et al. Gezondheidsbevordering en voortgezet onderwijs: verstandshuwelijk of echte liefde? (lezing). In Congres Nederlands Jeugdinstituut. Jeugd in onderzoek: de kracht van preventie in de jeugdketen. Nieuwegein. 2009.

Bos, V., Boot, N., et al. School health promotion and prevention in the Netherlands (lecture). In the 15th EUSUHM Congress: Youth Health Care in Europe. Leiden. 2009.

Bos, V., Boot, N., De Jong, D. School health promotion and prevention in the Netherlands (lecture). In the 15th EUSUHM Congress. Youth Health Care in Europe. 2009. 
Bos, V., De Jongh, D., et al. (2009). Improving the whole school approach in the Netherlands. Better schools through health: learning from practice. Case studies of practice presented during the third European Conference on Health Promoting Schools. G. Buijs, A. Jociut, P. Paulus and V. Simovska. Lithuania: Vilnius.

Hesdahl, B., Boot, N., et al. GB-spiraal GGD Zuid Limburg: een integrale toepassing gezond samen verder (poster). In Nederlands Congres Volksgezondheid [Dutch Public Health Conference]. Rotterdam. 2009

\section{0}

Boot, N.M.W.M., Van Assema, P., et al. (2010). Professionele begeleiding bij de invoering van schoolgezondheidsbeleid (lezing). In Nederlands Congres Volksgezondheid [Dutch Public Health Conference]. Rotterdam.

Boot, N. (2010). Bijlage instrument samenwerking. In Handleiding Gezonde School. Bilthoven, Centrum Gezond Leven - RIVM.

Meijer, A., Triepels, W., et al. (2010). Module oriëntatie en organisatie. In Handleiding Gezonde School. Bilthoven, Centrum Gezond Leven - RIVM.

Boot, N.M.W.M., Van Assema, P., et al. (2010). “Gezondheidsbevordering en voortgezet onderwijs: verstandshuwelijk of echte liefde?" Tijdschrift voor Gezondheidswetenschappen 88(3): 135-143.

Boot, N., Van Assema, P., et al. (2010). “Professional assistance in implementing school health policies." Health Education 110(4): 294-308.

Boot, N.M.W.M., De Vries, N.K. (2010 (submitted)). “Implementation of school health promotion: consequences for professional assistance."

Pucher, K.K., Boot, N.M.W.M., et al. (2010 (submitted)). “Review: Does education benefit from school health promotion?"

\section{1}

Boot, N., De Jongh, D., et al. (2011). “De Gezonde School als methode voor GGD’en bij de invoering van schoolgezondheidsbeleid." TSG 89 (3): 222-28.

Timmers, M.A.J., Mathijssen, J.J.P., et al. (2011 (submitted)). Evaluatie van De Gezonde en Veilige School methode op basisscholen. Evaluatie regio GGD Hart voor Brabant. 